\title{
O conceito de imitação na ópera francesa do século XVIII
}

\author{
Rodrigo Lopes
}

LOPES, R. O conceito de imitação na ópera francesa do século XVIII [online]. São Paulo: Editora UNESP; São Paulo: Cultura Acadêmica, 2015, 255 p. ISBN 978-85-7983-663-3. Available from

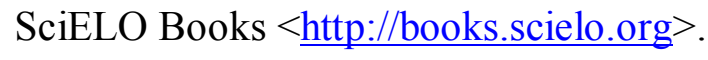

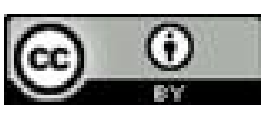

All the contents of this work, except where otherwise noted, is licensed under a Creative Commons Attribution 4.0 International license.

Todo o conteúdo deste trabalho, exceto quando houver ressalva, é publicado sob a licença Creative Commons Atribição 4.0.

Todo el contenido de esta obra, excepto donde se indique lo contrario, está bajo licencia de la licencia Creative Commons $\underline{\text { Reconocimento 4.0. }}$ 


\section{- CONCETO DE IMITAÇÃO NA ÓPERA FRANCESA DO SÉCULO XVIII RODRIGO LOPES}




\section{O CONCEITO \\ DE IMITAÇÃO \\ NA ÓPERA FRANCESA \\ DO SÉCULO XVIII}


CONSELHO EDITORIAL ACADÊMICO

Responsável pela publicação desta obra

\section{Graziela Bortz}

Ricardo Lobo Kubala

Nahim Marin Filho 
RODRIGO LOPES

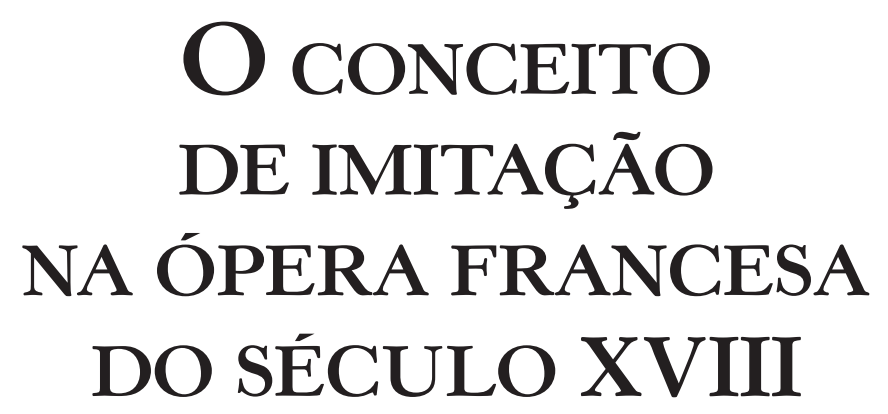

CULTURA

$\frac{\text { ACADÊMICA }}{\varepsilon d i t o n a}$ 
(C) 2015 Editora Unesp

\section{Cultura Acadêmica}

Praça da Sé, 108

01001-900 - São Paulo - SP

Tel.: (0xx11) 3242-7171

Fax: (0xx11) 3242-7172

www.culturaacademica.com.br

www.livrariaunesp.com.br

feu@editora.unesp.br

CIP - Brasil. Catalogação na publicação

Sindicato Nacional dos Editores de Livros, RJ

\section{L855c}

O conceito de imitação na ópera francesa do século XVIII [recurso eletrônico] / Rodrigo Lopes. - 1.ed. - São Paulo: Cultura Acadêmica, 2015.

Recurso digital: il.; $21 \mathrm{~cm}$.

Formato: ePub

Requisitos do sistema: Adobe Digital Editions

Modo de acesso: World Wide Web

ISBN 978-85-7983-663-3 (recurso eletrônico)

1. Arte e música - França - Séc. XVIII. 2. Óperas - França - Imitação.

3. Livros eletrônicos.

$15-26936$

CDD: 782.1

CDU: 82-293.1

Este livro é publicado pelo Programa de Publicações Digitais da Pró-Reitoria de

Pós-Graduação da Universidade Estadual Paulista "Júlio de Mesquita Filho" (Unesp)

Editora afiliada:

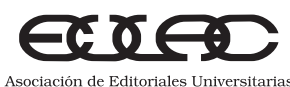

Asociación de Editoriales Universitarias de América Latina y el Caribe

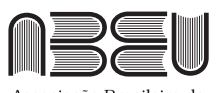

Associação Brasileira de Editoras Universitárias 
Neusa Lopes Bento, Bárbara Rodrigues Lopes (in memoriam) $e$ Mara Rossi (in memoriam) Pelo que me significam, pelo que me são. 


\section{Agradecimentos}

Agradeço à professora doutora Lia Tomás, pelas indicações, pelo auxílio nas traduções do francês para o português, pelo incentivo ao retorno para as Letras Clássicas.

Aos meus amigos, pelo incentivo, principalmente nos momentos difíceis: Cibele Rossi, Patrícia Rossi, Mara Rossi, Daniel Steiner, Maria Eugênia Sacco, Olmiro Borges, Luara Rocha, Marina Garuffi, Adriano Gado, Wellington Verdelli, Renato Cardoso, Marli e Glauce Fernandes, Emília, Tatiana e Daniela Paciello, Onofre João Rais (a quem também dedico este trabalho), Fábio Teixeira de Almeida (amigo desde o início dos anos 1990), Kenny Simões, professora doutora Elaine Sartorelli e Ricardo Barros.

Aos alunos que se tornaram amigos: Elisa Vieira, Camilla Roggero, Isa Marques Porto, Marina Takano, Lígia Francelino Alves, Silmara e sua filha Valentina, pelo carinho, pela curiosidade em relação ao trabalho, pela constante torcida.

Aos novos amigos da pós-graduação em Música da Unesp, Fabrícia Piva e João Rizek, pela amizade, pelo convívio em congressos, pelas ideias para o trabalho, muitas vezes divertidas, e aos amigos do Grego, e àqueles que não são do Grego, do curso de Letras da USP: às Flávias, Benini e Vaccaro, a Eduardo Pereira, 
Jurema, Maria Filomena e Tati, sempre amigos, divertidos e unidos em nome do conhecimento.

À Maria Suzanna do Carmo, por ter disponibilizado sua dissertação de mestrado sobre a tragédia raciniana.

Ao pessoal da secretaria da pós IA/Unesp e da biblioteca, sempre atento e prestativo, principalmente à Ângela Lunardi, pelos esclarecimentos sobre viagens para participação em congressos e sobre tantas outras dúvidas.

À minha mãe Neusa, pelo apoio, pela torcida, por muitas vezes ter ficado com meus gatos quando precisei me ausentar de casa para participar de congressos e encontros acadêmicos, e à minha sobrinha Alessandra da Silva Bento, por trazer uma nova e linda luz ao conceito de família.

À Yeda, por manter a vida doméstica em ordem quando eu não podia cuidar dela.

Agradeço à composição, junto à minha orientadora, da banca de qualificação e defesa de mestrado: professora doutora Yara Caznok, professor doutor Marcos Pupo e professor doutor Mário Videira, pelas suas observações, pelos consertos e elogios, muito valiosos para a configuração do meu trabalho.

Aos meus "filhos" amados, queridos e carinhosos: Isolda, Fellini, Ulysses (in memoriam), Fedora, Deméter e Demétrius, agradeço pelo amor constante e infinito, e ao Marcos Stephanno, pelo fervilhar da mente e do coração.

À Capes, pela bolsa concedida para o mestrado. 
As musas dizem mentiras semelhantes à verdade!

(Hesíodo, séc. VII a.C., Teogonia, verso 27) 


\section{SUMÁRIO}

Prefácio 13

Introdução 15

1 França entre os séculos XVII e XVIII 23

2 A imitação da natureza como estética dos sentimentos 79

3 França na segunda metade do século XVIII:

O movimento das querelas

A expressão em música 181

Considerações finais 241

Referências bibliográficas 249

Sobre ao autor 255 


\section{Prefácio}

Este livro é produto da pesquisa e da dissertação realizadas no mestrado em música pelo Programa de Pós-Graduação em Música do Instituto de Artes da Universidade Estadual Paulista Júlio de Mesquita Filho (IA/Unesp), cujo tema foi o conceito de imitação na ópera francesa do século XVIII.

Impossível, e longe de esgotar o tema nos nossos estudos, observamos que o conceito de imitação foi muito forte na orientação das artes e da ópera até o século XVIII. A França, nessa época, demorou mais tempo para se distanciar das regras das teorias imitativas do que países como a Itália e a Inglaterra, que já se conduziam por outros paradigmas na orientação das artes, e aqui buscamos, no que diz respeito à nação francesa, traçar um panorama dos seus usos e das suas transformações no decorrer desse século.

As teorias imitativas, neste livro, foram observadas na ópera quanto ao sentido estético-musical e ao modo como os seus conceitos eram tratados em meio às reflexões filosóficas do chamado "Século das Luzes". Os olhos da época voltaram-se para esses conceitos devido ao seu vínculo com o Absolutismo francês, os quais perduraram enquanto essa sociedade existiu. Após a morte do rei Luís XIV, a força dessas teorias nas artes e na ópera começou a diminuir e elas sofreram transformações. 
Devido à grande importância do conceito de imitação para essa nação, constatou-se a existência de grande quantidade de autores pouco ou nada conhecidos no nosso tempo que trataram desse tema e que, infelizmente, não puderam ser estudados para este livro. De alguma maneira eles dialogaram com autores consagrados, como o Abade Dubos e Charles Batteux, estudados aqui, e que tiveram grande influência nas artes e na música do seu tempo. Espera-se que esse autores pouco conhecidos sejam estudados em momento oportuno.

Longe de ser uma prerrogativa ou prescrição para as práticas musicais chamadas de "historicamente orientadas", este livro pretende tão somente propor uma reflexão sobre as discussões estético-musicais existentes em torno do fazer musical ou de seus bastidores, mais precisamente, sobre a ópera.

Observando o que se esperava desse dispositivo imitativo e de que maneira as transformações sociais influenciaram o conteúdo da música daquele período, verificou-se que esse conceito representava um mundo através da ópera, expressava a cultura e o caráter nacional francês. Essa representação de mundo como mentalidade estava em diálogo com o que se conhecia sobre arte e cultura da Antiguidade Clássica, já que os franceses também se sentiam representantes da cultura antiga.

Estudos musicológicos em vínculo e comunhão com a História, a Filosofia e a Sociologia podem enriquecer-se ainda mais, esperando-se uma musicologia mais integrada com esses outros campos do saber, ampliando sua área de estudos não só no que diz respeito ao conceito de imitação em música, tão caro aos franceses dos séculos XVII e XVIII, mas também a todo e qualquer estudo que tenha como tema a música. 


\section{INTRODUÇÃO}

Dentre as doutrinas escritas para as artes particulares entre o século XVI e fins do século XVIII estavam as teorias imitativas que operavam o pensamento e a execução sobre o lugar, a divisão e a distinção da música e das artes enquanto práticas imitativas. A música era pensada como um discurso racional, articulada em segmentos como o de um texto literário, a partir de regras definidas. Sua escuta era uma escuta literária. As práticas imitativas davam forma e significado à música, pois nesse período, reconhecidamente o da modernidade, a valorização da razão sobre as sensações emocionais era muito maior, e essas práticas se sujeitavam a ela.

Com o Renascimento foram resgatadas da Antiguidade greco-romana a "imitação" como meio para o fazer musical, as formas e os gêneros poéticos literários que se tornaram correntes nas produções artísticas e musicais da época. Traduziu-se a Poética de Aristóteles, modelo para as teorias imitativas em uso, ao mesmo tempo que se desenvolviam as ciências. A partir de Descartes, o foco no racionalismo ${ }^{1}$ enquanto conceito orientava e controlava as emoções, as paixões humanas.

1 De acordo com o racionalismo, todas as coisas possuem uma causa inteligível, explicada pela razão. A razão é superior à experiência do mundo sensível; o seu 
Entre o fim do século XVII e a primeira metade do século XVIII, na França, concepções mecanicistas da natureza devido ao desenvolvimento das ciências influenciaram posteriormente a filosofia iluminista, que buscava nos estudos dos fenômenos descritos pela Física a compreensão dos fenômenos culturais e humanos.

A análise desses fenômenos deveria satisfazer às exigências do racionalismo, influenciado pela Física, e a música, em meio a essa concepção de época, era um elemento subjetivo, inclinada ao caráter do coração, como meio de despertar as sensações sentimentais, sendo então incapaz de satisfazer, por si mesma, às condições da razão. As outras artes apelavam ao espírito e à razão, e a poesia era uma expressão da razão. Por esse motivo, a música ocupava um lugar e uma função secundários na sociedade francesa enquanto conceito, pois não apelava à razão como as outras artes, mas sim aos sentidos.

Antes de a estética musical se tornar um segmento específico do conhecimento na segunda metade do século XVIII, os comentários e as reflexões estéticas já aconteciam, como foi observado em tratados e escritos de época dedicados à música. As ideias assim referidas eram encontradas em registros que iam desde a Antiguidade ao Renascimento. As ideias estéticas que os norteavam contemplavam assuntos diversos, eram mencionadas em textos de outros saberes, como de metafísica, ética, matemática, cosmologia, em manuais de regras de conduta e poética, além de serem associadas às teorias matemáticas e harmônicas, de maneira semelhante à língua e também aos efeitos resultantes das paixões humanas. Por ter feito parte de vários assuntos por muito tempo e não ter constituído um campo individual de estudos, sua definição era menos precisa. As novas concepções de natureza e realidade advindas do racionalismo francês influenciaram e produziram transformações na sociedade francesa desse período, além de trazerem um novo olhar com

método de investigação filosófica é o dedutivo, como ocorre em Descartes, que associa o racional com o real, supondo a plena inteligibilidade da realidade; seu princípio está na busca da certeza e na demonstração produzidas unicamente pela razão. 
relação às práticas musicais. A música esteve em função de muitas atividades humanas, como rituais, comemorações, eventos políticos, cortejos, por isso era mencionada em muitos relatos desses eventos. $\mathrm{O}$ conceito de imitação, no que se refere à música, também sofreu modificações por conta dessa nova concepção de mundo. A imitação seguia regras bem definidas, baseadas em modelos da natureza. O próprio conceito de natureza se transformou, a ponto de as produções musicais, mais especificamente, a ópera, terem passado a demonstrar, a partir do século XVIII, essa mudança no dispositivo imitativo, até o seu efetivo desuso enquanto regra que respeitava os moldes clássicos, o que se revelou nos gêneros poéticos circulantes no período e nas críticas feitas à não observância e ao não cumprimento das regras pertinentes às teorias imitativas.

A imitação, na ópera, acontecia de acordo com a tradição clássica, ${ }^{2}$ a qual era constituída tanto pela tragédia antiga como pela tragédia clássica francesa do século XVII. O conceito de mimese ou imitação na ópera teve respaldo, num primeiro momento, entre o século XVII e o início do século XVIII, na natureza como sinônimo de "razão". Ou seja, a imitação deveria embelezar e tornar agradável a verdade racional. Num segundo momento, que compreendeu a primeira metade do século XVIII, com as mudanças de concepção de pensamento, em decorrência das ideias iluministas, a natureza passou a ser sinônimo de sentimento, e a imitação deveria passar então a realçar a verdade dramática ${ }^{3}$ segundo regras que a mantinham atrelada à realidade.

2 Segundo Abbagnano (2007), entende-se por tradição "herança cultural, transmissão de crenças ou técnicas de uma geração para outra. No domínio da filosofia, o recurso à tradição implica o reconhecimento da verdade da tradição, que, desse ponto de vista, se torna garantia da verdade e, às vezes, a única garantia possível. Foi entendida pelo próprio Aristóteles, que, em suas investigações, recorre frequentemente à tradição, considerando-a garantia de verdade. [...] $\mathrm{Na}$ atitude tradicionalista, o indivíduo considera como seus os modos de ser e de se comportar que recebeu ou continua recebendo do ambiente social, sem perceber que são modos de ser do grupo social” (p.966-7).

3 A verdade dramática estava relacionada à regra das três unidades - ação, tempo e lugar - no teatro clássico francês. Os autores do período acreditavam 
No século XVII e em meados do século XVIII, o conceito de imitação tinha, na natureza, o sinônimo de razão. Na primeira metade do século XVIII, a natureza era sinônimo de sentimento e, da segunda metade do século em diante, a música passou a abarcar a concepção de expressão. ${ }^{4}$

Na primeira metade do século XVIII, teóricos franceses cuja estética estava voltada para a natureza como sinônimo de sentimento, ${ }^{5}$ como o Abade Dubos e Charles Batteux, consideravam que a estrutura musical estava alicerçada e respaldada na linguagem verbal. A expressão musical dependeria da linguagem verbal para se projetar e sua função imitativa ou mimética teria foco na imitação da "bela

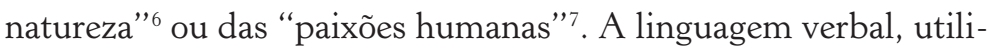
zada pela música vocal, expressaria os sentimentos, que seriam imitados de acordo com modelos retirados da natureza. A bela natureza tinha em si mesma modelos para a expressão das paixões humanas.

Perante esse quadro de acontecimentos e transformações que aos poucos alteraram as regras relativas ao dispositivo imitativo na ópera francesa, o trabalho que originou este livro discutiu o conceito de imitação na ópera francesa do século XVIII a partir deste questionamentos: Quais as concepções e os modelos miméticos

que essas unidades eram legitimamente derivadas de Aristóteles, por atenderem aos critérios rígidos da verossimilhança da ilusão teatral. Com elas, tinha-se a ilusão de que a representação teatral era uma ação real.

4 Segundo Abbagnano (2007, p.419), pode-se dizer que a beleza da natureza ou da arte é a expressão das ideias estéticas. Na arte, a ideia de expressão também pode ser apresentada por meio de um conceito. Na natureza, uma reflexão por si só pode ser suficiente para comunicar a ideia do objeto, sem necessitar de sua expressão; fora da arte, essa expressão seria necessária.

5 De acordo com Abbagnano (2007), ao sentimento se devem as primeiras certezas do raciocínio. Ele significa uma volta à natureza, libertando o homem dos artificialismos da sociedade.

6 A ideia de que a natureza era a ordem do universo é bastante concordante e consonante consigo mesma e predominou na ciência moderna (cf. Abbagnano, 2007, p.700).

7 Para Abbagnano (2007, p.739), as paixões humanas são o mesmo que sentimento. Elas penetram e dominam a personalidade e são capazes de ultrapassar obstáculos morais e sociais. 
utilizados na França do século XVIII? Como a mimese se atrelava à concepção de gosto e como se manifestava em textos e tratados musicais da época?

Ao procurar responder a essas questões, no âmbito da estética musical, baseamo-nos em textos franceses do século XVIII que trazem discussões e reflexões sobre a mimese ou imitação. Por ser vinculada ao gosto, a definição e a discussão de imitação envolveu necessariamente a definição e a discussão do conceito de gosto. Esses conceitos, interdependentes, foram se delineando e sendo incorporados pela estética musical ao mesmo tempo que essa área se estruturava como um campo independente do saber.

Os textos e tratados musicais franceses do século XVIII utilizados no nosso trabalho apontaram para uma trajetória, em suas reflexões estéticas, da concepção de natureza como imitação que se transformou aos poucos, como será observado nas polêmicas em torno da ópera francesa e da italiana, na função que a música deveria cumprir, no afrouxamento do vínculo da música com a tradição clássica, na clara certeza da real incapacidade da ópera de cumprir as regras das teorias imitativas estabelecidas pela razão. Os textos analisados apontaram os interesses musicais da sociedade francesa, em meio às transformações sociais que aconteciam nesse período.

No primeiro capítulo deste livro, nos ocuparemos da ópera francesa e de suas relações com a literatura e o teatro, de como ela trouxe para si e usou os modelos da tragédia segundo Aristóteles e da tragédia clássica francesa do século XVII, advinda da pastorale, da maneira como empregou as regras dramáticas teatrais dos dois modelos para se constituir como um espetáculo autônomo. Em seguida, refletiremos sobre a primeira discussão, do início do século XVIII, entre Raguenet e Lecerf sobre a ópera francesa e a italiana. Nessa discussão, foi possível depreender a ideia de natureza como sinônimo de razão, já que esse era o parâmetro para as regras das teorias imitativas, e também como posições opostas a esse modo de pensar começaram a se manifestar. Abordaremos também, nesse capítulo, os pensamentos de outros autores, como Le Brun e Saint-Mard, no contexto da ópera francesa. 
Nessa época pensava-se que, para a música possuir condições de se dirigir à razão, ela precisava da linguagem verbal, o que lhe permitiria ser compreendida, e para isso fazia uso da literatura, cuja linearidade racional era demonstrada através do libreto de uma ópera ou de uma peça de teatro. Segundo essas concepções, sozinha, sem o suporte das palavras, a música apenas se dirigiria às sensações, o que gerava dificuldades para a sua classificação.

A música, no século XVII, fazia parte de um processo definido, na criação musical, pelo ato composicional escrito, como ocorria com o ato composicional na estrutura literária de um texto, tanto que, na música instrumental do período, o caráter idiomático de um instrumento musical era fruto da integração entre "compor" e "tocar" na criação musical. A performance musical e a composição não eram práticas completamente separadas uma da outra.

Nos séculos XVII e XVIII, um autor, ao escrever seus textos, fazia-o como se eles fossem lidos em voz alta, criando assim uma representação, uma forma artística que tinha por fundamento a linguagem oral. Assim acontecia com a ópera francesa. A linguagem verbal deveria ser evidente, e apenas ela mesma seria capaz de criar uma representação dos significados de seu texto. Os textos deviam ser agradáveis, bonitos, o que era uma justificativa a mais para que a estética literária se aproximasse dos antigos clássicos, que deviam possuir elegância. ${ }^{8}$

No segundo capítulo, discutiremos o conceito de natureza como sinônimo de sentimento na segunda metade do século XVIII. A estética musical estabelecida pelo Abade Dubos, por Charles Batteux e por outros autores franceses, como Grandval, Bollioud-Mermet e Blainville, era a da imitação da natureza como sentimento, como será demonstrado a partir da leitura e análise de fragmentos de textos desses autores. A imitação, para eles, tinha a função de realçar os

8 O termo "elegância", segundo o Dicionário Houaiss Conciso (2011), significa: graça e distinção no porte e nos modos; comportamento cortês, distinto; gentileza, fineza; adequação e fineza na linguagem; correção de caráter moral, honradez (p.329). 
aspectos dramáticos da realidade, já que as paixões humanas eram os modelos retirados da natureza. Os textos também trazem suas críticas às transformações musicais do seu tempo.

No momento em que o conceito de imitação se reportava à natureza como sinônimo de sentimento na representação das óperas, os filósofos do Iluminismo francês, alavancados pelos enciclopedistas, ${ }^{9}$ combatiam a tradição clássica contida nas óperas, assim como a maneira de ser de muitas outras instâncias no Estado francês, pois viam na ópera uma representação da aristocracia, a qual pretendiam derrubar.

No terceiro capítulo, nos deteremos no movimento das querelas da segunda metade do século XVIII, na maneira como a chegada de uma trupe de ópera bufa italiana em Paris movimentou a ópera francesa e mobilizou filósofos, escritores e literatos em torno desse fenômeno, de como partidários da ópera bufa e contrários à opera seria combateram a tradição clássica. Nesse momento, o olhar não estava mais voltado para os modelos externos, como o eram aqueles retirados da natureza, mas para os sentimentos internos. Era a visão individual do artista que se faria presente e contrastaria na maneira de compor música, até então ligada a imagens de modelos externos. Estes modelos, em meio às polêmicas, passaram a ser vistos como a manutenção de uma tradição aristocrática que desejava ver nas óperas a transposição do seu comportamento, do seu poder e dos seus interesses, e por isso eles foram combatidos.

Posteriormente, trataremos o conceito de imitação como estética da expressão, pois, a partir da segunda metade do século XVIII, a música instrumental adquiriu maior relevância, e esse fato, somado

9 Os enciclopedistas e suas ideias não serão foco de nossa discussão e reflexão. No que diz respeito a eles, abordaremos as novas concepções de gosto surgidas em meio às questões relacionadas com a ópera francesa e italiana, questões que foram acirradas com o movimento das "querelas" na França, cujo intuito era combater a tradição clássica advinda da Poética de Aristóteles e do teatro francês do século XVII, usadas como modelos a serem imitados pela ópera francesa, pois eram vistas como uma personificação da aristocracia francesa, a qual visavam atacar. 
ao combate aos modelos imitativos, fez que a capacidade imitativa como meio de valorizar a música e as artes perdesse sua eficácia. $\mathrm{O}$ incremento na quantidade e a melhoria da qualidade da música instrumental geraram questionamentos relativos à proeminência da linguagem verbal sobre a música, se de fato esta deveria imitar e deveria mesmo produzir sentido. Dentre os autores que questionaram o poder imitativo da música e sua eficácia, temos André Morellet, que retomou questões tratadas em As belas artes reduzidas a um mesmo princípio, de Charles Batteux, procurando validar suas proposições.

Através do caráter subjetivo, Morellet trouxe reflexões sobre a expressão em música, e com ele tentamos encontrar respostas para os debates e as reflexões dos autores mencionados nos capítulos anteriores sobre o poder imitativo da música.

Os séculos XVII e XVIII legitimaram a monarquia estabelecida pelo Antigo Regime, que foi se fragmentando no decorrer do século XVIII. Com o declínio da monarquia, a teoria imitativa, que norteava a música e as artes, aos poucos foi se transformando.

Identificamos na trajetória estético-musical do Iluminismo francês permanências em meio a rupturas, o que foi eliminado e preservado. $\mathrm{O}$ exame dos textos dos autores mencionados e a história cultural como ferramenta nos orientaram nessa discussão, ao mostrarem como um grupo social, a aristocracia francesa, legitimou e satisfez seus interesses, justificando seu controle dentro da sociedade. A aristocracia representou uma leitura de mundo, mesmo que através de um poder forjado e autoatribuído, direcionando os costumes e as práticas comportamentais, o que era correto e incorreto na música e nas artes.

A cultura como mentalidade, manifestada através dos registros de cartas, registros literários, relatos de gostos, de conduta social, registros morais e cerimoniais, demonstra a relação existente entre as hierarquias sociais. Novas leituras do mundo aconteceram e continuam acontecendo, e nesse sentido a ópera francesa e o conceito de imitação funcionaram como relações de mentalidades, revelaram momentos de ruptura e permanência, em busca de uma nova mentalidade. 


\section{1 \\ França entre os SÉCULOS XVII E XVIII}

\section{A música e sua relação com a literatura e o teatro: o que a música imitava}

O conceito de imitação, na ópera francesa do século XVIII, deve a sua origem ao texto poético literário. O termo "imitação" derivou da Poética de Aristóteles, ao tratar a estrutura da tragédia. O objeto da tragédia era a imitação, a qual, por sua vez, tinha na ação de caráter elevado, na sua medida, enquanto extensão, e na forma da sua linguagem, os elementos que a constituíam. Sua manifestação ainda se dava, segundo Aristóteles, mediante a atuação dos atores, que deveria suscitar terror e piedade e, em consequência, purificar essas emoções na audiência. ${ }^{1}$

Essa estrutura, seguida por muito tempo no fazer literário e artístico, foi utilizada na constituição da ópera. O texto literário era aquele que continha a narrativa ou a poesia, transformada em ação na representação da ópera, a qual, por sua vez, era derivada do teatro. A ópera era um teatro cantado e seguia determinações bem definidas quanto às regras e aos efeitos esperados sobre uma

1 Baseado no Livro VI da Poética de Aristóteles (1986, 1449b 24). 
audiência, efeitos esses também esperados na representação de uma tragédia, assim como de uma pintura. ${ }^{2}$

A partir do texto literário, a imitação tornou-se regra e passou a orientar as artes e a ópera. O que era esse texto literário e quais as suas formas? Abordaremos, nesta parte, os seus elementos, a sua origem, como participou da constituição da ópera. A forma de imitar derivou de sua estrutura, fazendo que a ópera, antes de ser uma peça teatral cantada, fosse uma peça literária. Dele derivaram todas as questões sobre imitação na música, as quais, antes de serem uma discussão musical, constituíam, na verdade, uma discussão literária. Discutir imitação era discutir literatura, daí a sua importância no contexto deste livro.

O texto poético literário era o elemento racional pelo qual a linearidade da narrativa era disposta e apreendida pela razão. $\mathrm{O}$ teatro e a ópera imitariam suas ações para se constituírem como arte. Algumas formas literárias, como a tragédia antiga ${ }^{3}$ e a clássica, tornaram-se modelos de execução para as artes, entre elas, a ópera. Delas derivaram as regras e a maneira considerada a mais completa para a imitação.

Em relação à ópera, as ligações entre música e literatura se fizeram muito próximas desde o seu surgimento no período barroco. ${ }^{4}$ Além do elemento literário vinculado ao texto, a ópera se apropriou

2 Os efeitos esperados em uma representação de ópera eram o que se entendia por catarse na tragédia grega: terror e piedade sentidos ao mesmo tempo, em acordo com a Poética de Aristóteles.

3 Os preceitos aristotélicos estavam ligados à própria estrutura teatral, à própria definição de tragédia: "É, pois, a tragédia imitação de uma ação de caráter elevado, completa e de certa extensão, em linguagem ornamentada e com várias espécies de ornamentos distribuídas pelas diversas partes [do drama], [imitação que se efetua] não por narrativa, mas mediante atores, e que, suscitando o terror e a piedade, tem por efeito a purificação (catarse) dessas emoções" (Poética, livro VI, 1449b 24).

4 O uso do termo "barroco" é mais cômodo para o mundo italiano e o alemão, pois a música francesa sempre procurou ser autônoma e declaradamente posicionou-se contra a aceitação de influências italianas em seu seio, mesmo que isso tenha sido inevitável. 
dos elementos cênicos e dramáticos do teatro para se constituir. $\mathrm{O}$ texto literário, cuja narrativa podia ser organizada e considerada um acontecimento real, se completaria na encenação teatral. Na ópera, a esses dois elementos somava-se a música.

O texto literário era o elemento mais importante na música da ópera, dividido e distribuído em partes ordenadas. Em comum com a arte dramática, além de esta ser a base da sua construção, possuía um sistema verbal que direcionava a razão, a qual, por sua vez, direcionava esse espetáculo quando transformado em imagem cênica ${ }^{5}$ musical. Nas teorias imitativas dos séculos XVII e XVIII, a imitação possuía como prerrogativa a compreensão racional do texto teatral ou do libreto de ópera, o qual, expresso por meio da linguagem verbal, deveria demonstrar a lógica entre as suas partes e o encadeamento entre as ações. O texto literário representava a razão realçada pela música; esta era o suporte para o texto e deveria destacar seus aspectos verbais.

O texto poético literário na forma de libreto, na ópera francesa, tinha sua teorização e sua realização fundamentadas no modelo da tragédia antiga, de acordo com a Poética de Aristóteles, assim como no modelo francês de teatro dramático musical do século XVII, e assim se constituiu como teatro lírico. Com essa estrutura bem delimitada, criou-se uma barreira à penetração da ópera italiana (tema que será discutido adiante), e ele tornou-se autossuficiente na criação dramático-musical. A ópera francesa imitava, então, como na tragédia antiga, a ação poética de uma tragédia ordenada em diversas partes e organizadas primeiramente no texto literário, estruturando-se como um espetáculo legítimo.

No século XVII francês, os compositores, junto com os tragediógrafos, respeitavam a obrigação de conformar o estilo da ópera com a peça teatral. As personagens tinham tipos diferentes, como

5 Imagem cênica, nesse contexto, significa que a representação no palco deveria assemelhar-se a uma pintura, a um quadro do qual todos os elementos carregados de significados deveriam ser captados pelo olhar do espectador ao mesmo tempo. 
ocorria com os tipos da hierarquia social, e a partir delas os compositores se orientavam na composição da música, adequando sua escrita musical à personagem constituída para a ação.

A música vinculada ao canto da personagem trágica traria ênfase ao efeito da catarse diante do terror e da piedade sentidos pelo espectador, dado preconizado pela teoria clássica poética em relação à tragédia.

Outro dado de extrema importância foi a teoria da verossimilhança. ${ }^{6}$ Os gêneros teatrais que fizeram parte da poética clássica, a partir do início do século XVI, no momento em que se traduzia e comentava Aristóteles, deveriam se acomodar à unidade de tempo, de lugar e de ação, componentes da teoria da verossimilhança. $\mathrm{O}$ drama, na ópera, deveria satisfazer as regras, seguindo o pensamento aristotélico, e não contrariar as exigências da marcação das cenas, nem sua composição musical.

Já a ópera francesa que compreendeu o século XVII e meados do século XVIII se orientou por uma teoria literária envolvida por uma visão clássica de mundo, com particular enfoque sobre o conceito de natureza, ${ }^{7}$ e fundamentos filosóficos próprios. A ópera, tomada

6 Segundo Abbagnano (2007), por verossimilhança entende-se o que é semelhante à verdade, sem a pretensão de ser verdadeiro (no sentido, por exemplo, de representar um fato ou um conjunto de fatos). Portanto, uma narrativa, seja um romance ou uma tragédia, pode ser verossímil sem ser minimamente provável, sem que exista qualquer probabilidade de que os fatos contados tenham se verificado ou venham a se verificar. A partir de Aristóteles, tornou-se constante o emprego da verossimilhança na estética: "Narrar coisas efetivamente acontecidas não é tarefa do poeta; dele seria a tarefa de representar o que poderia acontecer, as coisas possíveis segundo a verossimilhança ou necessidade" (Poética, 1451a 36). Nesse sentido, verossimilhança é o caráter de enunciados, teorias e expressões que não contradizem as regras da possibilidade lógica ou das possibilidades teóricas ou humanas. Um acontecimento humano imaginado será verossimilhante se for considerado compatível com o comportamento dos homens ou se encontrar explicações ou respaldo nesse comportamento (p.1.000).

7 "A natureza é a expressão artística da verdade, sendo o tema central da crítica clássica. Em nome do 'natural' o excesso de ornamentos foi condenado, assim como o estímulo, o burlesco, o pedantismo. A mesma crítica preconiza ao 
por teatro lírico, era pensada, nesse contexto, e comportava-se de acordo com as características dessa teoria literária, e não só isso: ela as enfatizava e amplificava. Também regulava o sistema poético, embora não possuísse forma estrita nem significado totalmente de acordo com as leis que regulamentavam o teatro clássico, mesmo sendo considerada um teatro e exigindo-se dela o cumprimento de suas leis. O teatro era notadamente trágico, e a ópera também poderia ser trágica, mas o que ela tinha de original era a representação da tragédia através da música, forjando para si elementos propostos para outra arte, como da arte dramática.

Em conformidade com a tragédia clássica, os recitativos da ópera eram comparados com a declamação e os diálogos da tragédia. Para eles eram destinados os mais significativos elementos trágicos e as cenas da ação dramática, amplificados pela música, exigindo-se assim, da ópera, uma configuração teatral como a da tragédia. Sobre a ópera francesa ter sido considerada um teatro, afirmou a autora Catherine Kintzler (2006), filósofa francesa especialista em estética:

[...] Bref, Grimm, qui deteste l'opéra français, considère, comme Perrin qui en traça le programme, qu'il s'agit d'un théâtre et qu'il faut analyser cet opéra comme un véritable travail destiné à la représentation, racontant une histoire, susceptible d'être apprécié sur des critères tels que la vraisemblance, la nécessité, etc. Grimm est tellement persuadé qu'il y va de la théorie du théâtre qu'il n'hésite pas à faire largement appel, pour mener à bien son article, à de nombreux passages tirés de l'ouvrage de l'abbé Batteux qui se presente explicitement comme une poétique générale. Le texte de Grimm est l'un des derniers à considérer l'opéra français comme relevant intégralement de la théorie du théâtre classique. (p.12)

natural a elegância e delicadeza dos pensamentos e das palavras, e a adaptação de um texto ao público visa essas prerrogativas quanto a um gênero prático, em nome de um respeito apropriado ao príncipe. Busca-se, assim, se orientar por um 'estilo natural'” (Bury, 1992, p.419, tradução nossa). 
[...] Em suma, Grimm, que detesta a ópera francesa, considera, como Perrin, que traçou o programa, que se trata de um teatro e que é necessário analisar essa ópera como um verdadeiro trabalho destinado à representação, como uma história suscetível de ser apreciada segundo critérios como os da verossimilhança, da necessidade etc. Grimm está tão convencido de que existe uma teoria do teatro que não hesita veementemente em apelar, para bem posicionar seu artigo, a numerosas passagens tiradas da obra do Abade Batteux, a qual se apresenta explicitamente como uma poética geral. O texto de Grimm é um dos últimos a considerar a ópera francesa como integralmente relevante à teoria do teatro clássico.] (Tradução nossa)

Na representação teatral, os fatos eram organizados numa ordem considerada poética, obtida através do mito. ${ }^{8}$ Como na natureza, a situação dramática era uma invenção esperada da união de opostos, uma produção poética pensada, arranjada, cujos contrários faziam parte de um mundo poético comum. A representação de uma cena se fazia pelo jogo de contrários, como ocorria na natureza, e por isso mesmo ela se referia a uma possibilidade de pensamento sobre a ficção como estética.

8 Segundo Abbagnano (2007, p.673), dentre as acepções de mito na Antiguidade inclui-se a de ser algo não demonstrável nem claramente concebível, mas é clara a sua acepção moral ou religiosa. $\mathrm{O}$ mito ensina aos homens como agir uns em relação aos outros, como se relacionar com a divindade. De acordo com outra concepção do autor, o mito é uma forma autônoma de pensamento e de vida, não subordinada ao pensamento racional, pois é uma outra forma de intelecto, originária e primária; embora diferente do plano intelectual, não deixa de ser dotada de igual dignidade. Nesse sentido, o mito tem o correlato das fábulas como se fossem narrações verdadeiras. Os mitos assumem caráter poético e possuem significado histórico. Nos primeiros tempos, eles foram transmitidos oralmente pelos povos. Como nas fábulas, consistem, em sua essência, na necessidade de extrair as formas e as propriedades dos assuntos e de transmiti-las de alguma maneira, como uma forma de pensar dos povos. 
Assim, a ópera francesa teve sua origem na forma teatral da pastorale dramática francesa, ${ }^{9}$ constituindo-se posteriormente na tragédia lírica ou tragédia em música, ${ }^{10}$ gênero de ópera considerado o mais bem acabado na França dos séculos XVII e XVIII. Teatralmente, os autores de pastorales dramáticas não deixaram de expor,

9 A pastorale dramática sofreu transformações. Sua forma provençal foi apropriada e assumiu características dramáticas. Segundo Liliane Picciola (1992): "[...] A pastorale provençal nos dá hoje uma ideia do que poderiam ter sido as pequenas ações dramáticas. O universo pastoral teve mais chances de agradar aos pregadores do século XVI, especialmente aqueles que se aproximaram dos meios rurais, que nunca deixaram de celebrar as virtudes da vida simples do campo, enquanto se opunham aos vícios favorecidos pela existência urbana. No século XVII, a evocação da vida pastoril teve a especial vantagem de situar a ação dramática fora do tempo, numa espécie de Idade de Ouro. Até mesmo os menos religiosos cultivavam essa nostalgia. Mas qual seria o conteúdo, desde o instante em que a ação se destituiu de seu contexto cultural, pertencente à pastorale dramática? No século XVI, os estudiosos da Espanha, Itália e França aspiravam a um gênero poético praticado pelos gregos das ilhas no século III a.C. e que havia sido imitado pelos romanos no século I a.C. Tinham [como modelo] o texto grego dos Idílios de Teócrito e o texto latino das Bucólicas ou Éclogas de Virgílio. Eram poemas dialogados, que falavam da realidade de parte dos camponeses da Sicília, e, por outro lado, da campanha romana. As Bucólicas de Virgílio, em particular, foram um eco para o drama que representou para os pequenos agricultores o confisco das suas terras pelos soldados e o seu exílio forçado. Eles expressaram seu desespero por ter de deixar a sua vida doce, regular, próxima da natureza. Mas os pastores se mostraram também como poetas e amantes" (p.80, tradução nossa).

10 A tragédia lírica (ou tragédia em música) foi um gênero musical especificamente francês. Predominou na corte nos séculos XVII e XVIII. Era representada em cena na Academia Real de Música de Paris [Académie Royale de Musique] e difundida pelas cidades francesas e também no estrangeiro. Nesse espetáculo, considerado completo, todos os elementos - o texto (sempre em versos), a música, a dança, os costumes, as máquinas, as luzes... - recebiam a mesma importância. A intriga, na tragédia lírica, de cunho mitológico, explorava os mitos greco-latinos ou os poemas épicos da Renascença. Deuses, heróis, monstros, fenômenos naturais, tudo compunha o espetáculo do maravilhoso. As cenas, verossimilhantes, eram entremeadas com dança. Derivada do balé de corte, a tragédia lírica constituía uma ação dramática cantada que dava respaldo a um balé. Buscava a simplicidade, a sobriedade, a naturalidade e a verdade. Esse tipo de espetáculo devia satisfazer o espírito, os olhos e os ouvidos do espectador. 
em suas composições, detalhes realistas. No século XVII, o caráter pastoril dessas peças começava a se tornar ausente, com a inserção de muitos episódios de guerra, em que batalhas e duelos ocuparam um lugar em suas representações, e por muito tempo esse tipo de representação foi bastante comum. Essas qualidades inseridas na pastorale não possuíam elas mesmas, em separado, uma espécie definida de gênero. Na Poética de Aristóteles, em comparação com a pastorale, era demonstrado certo desprezo pelos espetáculos fáceis, mais ainda pelo gênero não codificado. Para ele, a existência de acontecimentos infelizes não fazia uma obra ser uma tragédia. Esta deveria ser realizada com eficiência e seguir uma trajetória linear, como ocorria com o movimento do Sol. A pastorale, então, de acordo com a tradição aristotélica, não era codificada, pelo contrário, possuía alterações que a descaracterizavam enquanto gênero.

As transformações feitas na pastorale tornaram-na um laboratório poético da cena lírica e foram incorporadas pela tragédia clássica do século XVII. A introdução da dimensão heroica e da violência nas primeiras pastorais trouxe à ópera um novo colorido e novas nuanças.

Aos poucos, o rigor das tragédias ${ }^{11}$ antigas foi incorporado pelas pastorales, as quais se dramatizaram com seus temas. As tragédias de temática antiga atraíam bastante o interesse do público francês. Nelas havia um cultivo pelo horror, daí a admiração pelas tragédias do autor latino Sêneca (4 a.C.-65 a.C.), nas quais eram feitos uma pesquisa e um cultivo de sensações fortes. As tragédias poderiam ser cruéis, mas eram consideradas excelentes tanto nos seus modos como nos seus efeitos. Segundo a concepção da época, a purgação das paixões, ${ }^{12}$ de acordo com o pensamento aristotélico, se fazia

11 Goldmann (1970) escreve sobre o conteúdo da tragédia: "Nós chamaremos 'tragédia' toda peça na qual os conflitos sejam necessariamente insolúveis, e 'drama' toda peça na qual os conflitos sejam ou solúveis (pelo menos no plano moral) ou insolúveis devido a uma intervenção acidental de um fator em que, de acordo com as leis constitutivas do universo da peça, não se poderia intervir" (p.15, tradução nossa).

12 A purgação ou purificação das paixões era o efeito da catarse, os sentimentos de piedade e terror vivenciados ao mesmo tempo diante de cenas trágicas. 
melhor e denunciava a compaixão que se aprovava como "maravilhosa", e o terror instaurado pelo horror. A eminência da morte e os crimes deveriam ser coisas visíveis, ${ }^{13}$ daí Sêneca ter sido tão apreciado. Sistematicamente ele utilizava personagens horríveis da mitologia, como Medeia e Hércules, que mataram os próprios filhos, ou Tieste, que comeu os seus descendentes num ato de canibalismo.

Os elementos constitutivos da tragédia tomados posteriormente pela pastorale fizeram desta um modelo para a ópera francesa. Sua forma foi definida pelos trágicos franceses Pierre Corneille ${ }^{14}$ (16061684) e Jean Racine $e^{15}$ (1639-1699), este mais apreciado do que o primeiro, do qual procurou ser o oposto em suas composições. Preferiu heróis e personagens imperfeitas para uma tragédia verossímil, e por isso mesmo o amor, por exemplo, era um tema que poderia sobrepor-se aos interesses de Estado. As forças que impulsionavam as personagens para o seu desempenho trágico também promoviam

13 Toda tragédia trazia uma reflexão. Abordava a violência política e privada, chamando indiretamente todos a satisfazer suas paixões, seja pela vingança ou pela glória.

14 Pierre Corneille "[...]era um artista no uso da preparação, na criação de situações dramáticas. Ressaltam a agudeza de suas análises psicológicas, o contraste empregado nos caracteres e nas cenas, os métodos para aguçar o apetite de sua audiência e satisfazê-la. Seu esforço para criar situações e escrever fazia que se esquecesse da realidade. Suas personagens podem argumentar e analisar muito" (Lancaster, 1942, p.67, tradução nossa).

15 Racine "aceitou a forma clássica [Antiguidade Clássica] como esta havia sido fundada, repartindo-a, como muitos outros fizeram, apenas em detalhes. Ele difere de Corneille pelo estreitamento do leque de interesses. Produziu muito menos, [mas] colocou na maioria das suas tragédias mais ênfase sobre o amor do que sobre a admiração, por mostrar-se menos disposto a aceitar o vrai [verdadeiro] em lugar do vraisemblable [verossímil], deu maior atenção ao seu próprio estilo. Em alguns momentos ele emprega frases curtas e uma perífrase elegante, próximas à prosa, mas conhece o segredo da preservação do tom trágico. Sua obra é a melhor defesa dos métodos clássicos aplicados à tragédia. Sua genialidade, como a de um pintor de caracteres, sua criatividade nas situações não poderiam ter sido aprendidas na escola de D’Aubignac, mas ele também não teria sido o dramaturgo que foi se não tivesse por detrás dele não somente Eurípides e Sêneca, mas Corneille, Rotrou, D’Aubignac e outros autores franceses, além de outros elementos, cristãos e pagãos, que compunham a França do século XVII” (Lancaster, 1942, p.92-3, tradução nossa). 
o seu fortalecimento. Muitas vezes, essas forças pareciam insignificantes para as almas obstinadas. A fatalidade também encontrava meios de fazer mudanças em suas vidas. $\mathrm{O}$ amor muitas vezes era recíproco, porém, o obstáculo para a sua concretude estava do lado de fora da cena.

Racine usou personagens da Antiguidade como modelos para as suas tragédias, porém tornou-as mais humanizadas, e esse traço passou a constituir um caráter da tragédia clássica francesa. Na Poética de Aristóteles, as personagens da tragédia deveriam se caracterizar a partir de modelos da mais alta classe social, e elas se mostraram adequadas para as tragédias de Racine. Em certa medida, eram conduzidas ao pecado sobretudo quando perdiam o poder. Muitas personagens do autor usavam de seu poder para forçar a vontade dos que não nutriam bons sentimentos por elas e eliminavam seus rivais.

As personagens eram tomadas por uma paixão que levava-as a agir como se obedecessem a uma vontade incontrolável, usando o seu poder, mesmo que provisoriamente ou por delegação, sendo tomadas pela ilusão de que controlavam o destino dos outros. Encontravam prazer em fazer sofrer aqueles a quem amavam, que algumas vezes eram seus rivais. $\mathrm{O}$ poder parecia servir ao amor de todos, facilitava a realização do destino trágico. ${ }^{16}$

O filósofo e sociólogo francês Lucien Goldmann (1970), ao tratar esses conflitos no interior da tragédia clássica francesa do século XVII, escreveu:

Compreendemos por que os conflitos trágicos são antecipadamente insolúveis. A exigência de valores absolutos, de totalidade que rege o universo de toda tragédia, se opõe de maneira radical e

16 Em Racine, as personagens tornam-se seus próprios algozes, e o destino, nesse sentido, é tão irônico que leva aos seus olhos ameaças, aflições, sofrimentos, os quais parecem chegar como uma reflexão tardia. $\mathrm{O}$ mal que chega para esses heróis vem de longe, e em cena eles procedem de uma maneira que faz que ele se concretize. As intempéries do destino são de carne e osso, são concretas, e fazem os próprios protagonistas desencadear todas as ações e todos os sentimentos que, combinados, produzem a desgraça. 
irremediável a um mundo regido pelo compromisso, pelo relativo, pelo mais ou menos.

Assim, estes são os elementos constitutivos de toda tragédia: um conflito essencialmente insolúvel, resultante do choque entre um mundo que conhece o relativo, o compromisso, o mais ou menos, e um universo dominado pela exigência de valores absolutos, de totalidade, regido pela lei do tudo ou nada. (p.18, tradução nossa)

Para aperfeiçoar o objeto escolhido, a literatura refletia e ao mesmo tempo mimetizava momentos selecionados da realidade e do mundo, os quais eram transfigurados. Essa realidade tornava-se representativa para algo além dela, imanente à obra literária. A descrição de objetos, num texto literário, buscava elementos da realidade, embora não alcançasse a sua determinação real. Os objetos e as pessoas podiam ser unidades concretas, e da infinidade das suas características somente algumas eram aproveitadas para a sua fabricação e representação.

O texto literário, como acontece com a nossa visão diante de diferentes situações, captava momentos fragmentados e limitados da vida, ou de uma vida fictícia, para a constituição de sua representação. Só uma parte da vida, ou da invenção da vida, poderia ser caracterizada, mesmo que fosse projetada como real e determinada.

Sobre esses fragmentos retirados de momentos da vida, assinalou o crítico alemão e teórico teatral Anatol Rosenfeld (1970):

De certa forma, as orações de um texto projetam um mundo bem mais fragmentário do que a nossa visão já fragmentária da realidade. [...] A personagem de um romance, mais ainda de um poema ou peça teatral, é sempre uma configuração esquemática, tanto no sentido físico como psíquico. (p.32)

A ópera francesa se estabeleceu nessa esfera, porém nela a matéria poética literária, embora fosse o seu elemento regulador, não era dominante, mas impulsionava os acontecimentos. Em boa parte do tempo, a música dominaria, tanto em quantidade como pelos meios 
de realização de sua poética. A matéria poética literária de uma ópera colocaria a música em situação poética. Em senso estrito, o texto literário não asseguraria unicamente e por si mesmo a função dramática representativa. A ópera ocorreria como meio poético, se apresentaria como modelo literário ${ }^{17}$ e se tornaria, assim, um objeto literário. Esse meio poético fazia a ópera ser definida muitas vezes como um teatro lírico (no sentido de cantado = lira), como um teatro cantado, embora isso não fosse suficiente para descrever a função da música no teatro e meio poético.

Sobre essa questão, Catherine Kintzler (2006) destacou:

[...] L'agencement des faits qui caractérise l'opéra comme théâtre est essential, il peut et doit se dérouler par des voies musicales, mais, ce faisant, le musician travaille en tant que poète et se règle sur l'art du théâtre, qui est un art littéraire. Le musicien d'opéra traite la musique comme étant susceptible de produire un effer littéraire, en l'occurrence dramatique. (p.16)

[...] A combinação dos fatos que caracteriza a ópera como um teatro é essencial, pode e deve se desenvolver pelas vias musicais, mas, ao fazê-lo, o músico trabalha como um poeta que se regra pela arte do teatro, que é uma arte literária. O músico de ópera trata a música como sendo suscetível em produzir um efeito literário, uma ocorrência dramática.] (Tradução nossa)

17 Segundo Bury (1992), embora o modelo para as tragédias seja o da Poética de Aristóteles, a tragédia do século XVII, que serviu de base para a constituição da ópera francesa, não segue estritamente o modelo aristotélico. Existem diferenças entre elas. Na tragédia do século XVII, as personagens eram nobres, como os da Antiguidade greco-latina, mas não havia mais o coro - elemento que na ópera francesa será mais explorado. Mas tanto em uma como na outra prevalecia a ideia de que a violência e a mudança de sorte advêm do seio da família, das amizades ou do amor. As personagens se esforçavam por controlar as suas paixões e expressá-las. O prazer do espectador estava em observar a unidade de lugar (que podia ser indicado pelo cenário, quando os acontecimentos ocorriam em dois lugares ao mesmo tempo) e a unidade de tempo (quando a ação alcançava a sua eficácia por meio da verossimilhança) (p.423). 
Segundo a autora, a música de ópera se definia no fazer essencialmente teatral e, embora garantisse uma função poética completa, por si mesma, contribuiria para o arranjo dramático, já que tinha o mesmo tipo de presença literária de uma peça teatral. $\mathrm{O}$ material poético musical de uma ópera era análogo ao material poético literário, e não apenas uma redução ilustrativa literária. $\mathrm{O}$ dispositivo poético literário de uma ópera era inseparável da música. Nesse caso, o compositor escolheu o elemento literário como parte da natureza poética musical da ópera, e o músico, ao pensar a música literariamente, fazia assim porque a música havia sido distribuída ordenadamente num dispositivo poético, como a ordenação narrativa de um texto literário.

O texto literário era mais importante do que a música de ópera e sua relação com a imitação procurava enfatizar a prosódia na arte poética: o significado das palavras deveria ser evidente e a imitação devia ser associada a uma trajetória literária e, posteriormente, transformada em cena ou teatro cantado. A escolha da ópera como gênero era essencialmente uma escolha cênica, envolvendo, certamente, o estilo do músico, sua habilidade na composição e na execução. Porém, devido ao próprio gênero, todos esses componentes se achavam colocados sobre a ideia de teatro. O efeito musical só era possível se associado com o efeito poético. A clareza das palavras permitiria uma escuta literária. $\mathrm{O}$ recitativo ${ }^{18}$ deveria ser dominante, como dito anteriormente, e receber as grandes cenas dramáticas na ópera, porque o texto deveria ser compreendido pelo espectador. Por este motivo, as árias individuais eram em número reduzido, e assim mesmo nunca se libertaram totalmente dos ver-

18 O recitativo era um tipo de escrita vocal, normalmente para uma única voz, que seguia os ritmos e as acentuações naturais do discurso, além de seus contornos em termos de altura. O "stile recitativo" esteve ligado ao desenvolvimento de um estilo com notação rítmica precisa, apoio harmônico, largo âmbito melódico e um tratamento afetivo (emocionalmente significativo) do texto, promovido pela Camerata florentina no final do século XVI (cf. Sadie, 1994, p.769). 
sos, cujas inflexões deveriam ser rigorosamente seguidas. Como na Antiguidade Clássica, devia ser dada grande importância ao coro, o qual, na ópera francesa dos séculos XVII e XVIII, era composto por personagens secundárias.

Em termos musicais, os recitativos recebiam maior carga dramática e, embora com a prerrogativa de serem simples, a sua música deveria por si mesma comunicar esses efeitos do texto, estando assim mais próxima da razão, com a função de provocar um movimento das paixões humanas.

A escuta literária era tão importante na representação da ópera que a música era inserida cuidadosamente, como se surgisse de maneira natural na situação dramática. O musicólogo e novelista francês Philippe Beaussant (1997) observou:

[...] buscava[-se] multiplicar as situações em que a música pudesse surgir de maneira natural, esmerava-se em tecer um enredo dramático no qual a música e a dança viessem espontaneamente enxertar-se. Foi desse modo que [Molière] ensinou ao músico Lully, seu colaborador, que uma ação contínua e coerente era conciliável com a música e também com o balé. Graças à influência indireta de Molière, o balé de corte pôde evoluir no sentido da ópera, por meio da inserção de uma ação dramática. (p.368)

A natureza era o meio físico que funcionava como uma lente pela qual se observava a realidade e da qual se retiravam todos os modelos que serviriam de base para a atividade artística. À forma de imitar ou representar esses modelos, que deveriam ser aperfeiçoados e melhorados de modo racional, dava-se o nome de mimese, e na ópera a imitação seria possível e validada pela linguagem verbal, através do significado das palavras.

$\mathrm{O}$ aperfeiçoamento desses modelos retirados da natureza e utilizados nas artes não só direcionou uma forma de fazer ópera, mas também condicionou comportamentos sociais, ações e experiências, trazendo um caráter específico para as óperas francesas. $\mathrm{O}$ modo de aperfeiçoar estava sob o crivo do próprio caráter nacional 
francês, ${ }^{19}$ expresso pela aristocracia, cujas leis se tornaram preceitos universais para as artes, em especial para a música e a ópera.

Acreditava-se, nessa época, que a expressão e os significados da ópera só eram possíveis se vinculados ao texto literário utilizado por ela, cuja linguagem verbal era seu modelo formal. A música só era considerada portadora de significados se tivesse o texto literário junto com ela, caso contrário, era vista sem significado ou com significado duvidoso.

Essa linguagem possuía um poder persuasivo do qual a música se apropriou, e seu éthos ${ }^{20}$ eram as paixões humanas. Nesse período, as paixões humanas, os sentidos e as sensações eram racionalizáveis, de acordo com a concepção racionalista da época. Ou seja, as sensações e os objetivos que se pretendiam com seus efeitos poderiam ser direcionados pela razão. Pela palavra, as paixões eram tornadas mais precisas, e a música, nesse caso, universalizava seus significados.

A concentração no éthos, na composição da ópera, tinha por finalidade "mover as paixões" humanas de seus ouvintes, cujas características se constituíram não só pelo que se pensava, desde o Renascimento, de como deveriam ser seus efeitos numa audiência

19 Pauline Kra, astrônoma e matemática, professora de Francês da Universidade Yeshiva, de Nova York, explica que o conceito de caráter nacional foi um assunto debatido durante o século XVIII na França. No início, foi observado como um fato histórico; no final, foi considerado uma força ativa na política e que deveria ser usado para promover a própria reforma política. A formação desses traços nacionais contemplava questões geográficas, fatores físicos e espirituais. A definição mais ampla de caráter nacional, e a sua mais completa análise foram apresentadas por Montesquieu, com o nome de esprit général (espírito geral), o qual consiste em características morais, formas de pensar e comportamentos que resultam de uma combinação única de clima, religião, leis, máximas de governo, história, costumes e boas maneiras. O que distingue uma nação de outra é uma combinação única desses fatores, um padrão distinto de interação e interdependência entre eles e o conjunto peculiar de traços morais que produzem. O caráter moral, composto de uma mistura de virtudes e vícios, como a sociabilidade, a sinceridade, a vaidade, a generosidade, o orgulho, a preguiça, a honestidade, é parte da entidade maior do esprit général. A qualidade do caráter em si depende da maneira como os diversos traços são combinados e equilibrados nesse sistema (cf. Kra, 2002, p.1-4; tradução nossa).

20 Éthos é o nome que se dá ao conteúdo usado como tema no discurso. 
na Antiguidade Clássica, mas também pela influência da obra As paixões da alma (1649) de René de Descartes (1596-1650), no século XVII.

Descartes fundamentou uma autonomia do discurso musical, em que a filosofia e a teoria da música não dependeriam mais da cosmologia e da teologia. Ele pensou em regras musicais, como o número de consonâncias admitidas na composição, os movimentos das vozes. Não se prendeu a símbolos e analogias, mas focou as funções das propriedades sonoras em si mesmas, levando em conta os efeitos musicais produzidos nos ouvintes. Partindo para uma estética mais subjetiva, Descartes acreditava que a apreciação do intervalo na verdade reforçava o domínio do julgamento pessoal, mais do que a perfeição acústica em relação aos números. Escreveu a Mersenne em 1630 dizendo não reconhecer os aspectos característicos das consonâncias correspondentes às paixões. Para ele, as paixões constituíam percepções que se relacionavam com a própria alma. Seriam os sentimentos porque a alma as receberia da mesma maneira como se recebem objetos externos, e era esse recebimento que movimentaria a alma.

As paixões não possuíam com o corpo relação como aquela que ocorre, por exemplo, quando sentimos frio. Não representavam objetos, pois eram particulares à alma, e apenas teriamos consciência dos modos de ser das paixões, embora fossem causadas pelo corpo. A sua origem estava no corpo físico, daí a alma não ter controle sobre elas. A ação das paixões estava no fato de serem representadas através de objetos que suscitavam paixões, daí ser a reguladora das paixões originadas no corpo. A alma poderia decidir e conduzir as ações.

Descartes afirmava que uma mesma causa poderia provocar diversas paixões, o que possuía mais relação com a história pessoal de cada um do que com determinadas causas exteriores. Os movimentos transmitidos ao cérebro "representam os objetos à alma e fazem-na ter diversas sensações" (Rovighi, 2006, p.109). Existiam, para Descartes, seis paixões distintas, das quais todas as outras dependeriam: a admiração, o amor, o ódio, o desejo, a alegria e a tristeza. Rovighi (2006) escreve: 
Todas as paixões são reações da alma ao que é benéfico ou nocivo (art. 52); mas, na frente de todas essas reações, Descartes põe a admiração, suscitada por aquilo que é novo e inusitado nos objetos (art. 53). É uma paixão que tem por objeto o conhecimento, e por isso seus movimentos permanecem no cérebro (art. 71). A admiração suscita o desejo de conhecer, reforça a atenção, é mãe do saber (art. 75), mas mesmo esta é moderada, porque poderia levar-nos a querer conhecer também o que não vale a pena. (p.111)

No entanto, a sua filosofia, se assim se pode chamá-la, contida no Compendium Musicae, abordou a questão do belo a partir dos problemas musicais e acústicos. A música era um suporte para a reflexão estética, embora se aprofundasse em questões técnicas e acústicas. O pensamento de Descartes conduziu a uma estética de tendência "clássica", mas subjetiva. Ele recuperou as teorias antigas, muito desenvolvidas nos escritos do século XVI, mas deu-lhes uma "roupagem" epistemológica nova, distante do discurso metafísico e cosmológico sustentado nesse período. Sua obra, segundo Wymeersch (1999, p.113), possuía uma ambiguidade: apresentava uma aparência clássica, e, na sua estética das paixões, o prazer das emoções parecia superior à razão; apresentava concepções clássicas do prazer estético, pois para ele todos os sentidos eram capazes de qualquer prazer. No seu pensamento, os objetos eram adaptados, estabelecidos em proporções, de modo que se pudesse apreendê-los pelas sensações, de maneira distinta e sem dificuldades. Nesse sentido, a proporção era aritmética, não geométrica, pois esta seria uma proporção irracional, não perceptível pelos sentidos, o que os fatigaria. A beleza dependia de uma adaptação do objeto aos sentidos e da proporção interna dele, qualidade objetiva apreciada pela razão. O critério principal para o julgamento da beleza de uma obra era sua justa proporção. Por isso, os ritmos, na música, deveriam ser iguais, para que o canto desse uma impressão de unidade.

Proporção, equilíbrio, unidade e simetria eram as noções características da estética dita "clássica". O belo fazia sua ligação com o objeto musical, e não com o sujeito que o contemplava. $\mathrm{O}$ objeto da música era o som, e o seu fim era o prazer de mover em nós as 
várias paixões. A essência da música era suscitar no ouvinte uma reação. Mais importante do que o prazer em si mesmo era o sentimento de prazer que sentimos dentro de nós mesmos. Ele não era unicamente intelectual, mas estava ligado à sensação. $\mathrm{O}$ ego tinha sua subjetividade exacerbada pela emoção e pelas paixões, mas era pelo reforço da razão que se adquiria o conhecimento do universo e o controle das emoções.

Segundo a concepção de Descartes, as paixões produziriam um efeito mental (racional), mas suas causas teriam origem física. Por conta dessa teoria, a música cultivou uma concepção racional dos afetos.

O elemento racional da ópera, ou tragédia lírica, pressupunha a natureza como verdade abstrata em relações matemáticas formalizáveis. Sua ilusão, a verossimilhança, deveria revelar a verdade através da ficção teatral, da qual se desdobrariam seus encantamentos e cuja origem estaria na relação entre os significantes da linguagem verbal e os sons da música. A união desses elementos traçou uma concepção de mundo, de homem, de uma arte remontada aos números.

Por ter a natureza como modelo e verdade e se valer da ficção teatral, a ópera francesa também era considerada uma arte em condições de reviver o enredo, o mito da antiga tragédia grega, possuidora de encantos secretos, suavizadora da alma e ponte para o sensível.

O direcionamento das ações, na ópera francesa, pelo percurso do texto literário, deu a ela uma orientação quanto ao posicionamento das personagens, que deveriam ter suas hierarquias sociais bem definidas, e quanto àquilo que deveria ser imitado e também serviria de exemplo para os costumes, pois suas regras e modelos refletiriam regras e modelos de conduta em sociedade.

Devido ao caráter tradicional das artes e da música de ópera, que, por tradição, em seu fazer artístico utilizava modelos externos retirados da natureza e da Antiguidade Clássica, menor importância foi dada às relações estabelecidas com o aspecto individual do compositor. Não porque seus traços não fossem reconhecidos, mas porque os aspectos desses modelos eram mais fortes e arraigados na cultura francesa dos séculos XVII e XVIII. Seu mérito estava em saber compor, produzindo um diálogo entre o gosto vigente da aris- 
tocracia e do rei e a tradição da Antiguidade Clássica e da tragédia clássica francesa do século XVII mediante regras, tornando essas duas esferas reconhecíveis em suas composições. Sua tarefa era encontrar técnicas musicais para diferenciar os vários caracteres ${ }^{21}$ de suas personagens, identificadas no texto literário na forma de libreto, e dar-lhes tratamento de acordo com sua hierarquia social. Sua música deveria sinalizar esses aspectos das personagens, que na verdade espelhavam o domínio da aristocracia vigente.

Esses sinais musicais da natureza humana chegavam a ser confundidos com o seu referente, de modo que a ópera era descrita como uma encarnação da própria natureza humana. Os acentos do texto deveriam ter seus aspectos definidos e representados de acordo com a categoria social de cada personagem, por exemplo, um rei ou um pastor. $\mathrm{O}$ movimento de cada natureza humana pediria o tipo de acompanhamento musical mais apropriado, tendo-se o cuidado de demonstrar que a natureza de uma personagem era sempre a mesma e que as paixões sentidas por ela eram transitórias.

A literatura, no século XVII, na composição de suas tragédias teatrais, imitava os modelos da tragédia antiga. Transportados para a ópera francesa, como tragédia lírica, constituiriam modelos humanos e de comportamento dentro de uma concepção clássica de mundo.

\section{Discussões sobre ópera: paralelos e comparações entre França e Itália}

Com o surgimento da harmonia e do melodrama no início do século XVII, a atenção de filósofos, homens de letras e do público culto se voltou para esses dois elementos, os quais, transmitidos em tratados, artigos, panfletos, mobilizaram a cultura francesa e geraram polêmicas no decorrer dos séculos XVII e XVIII.

Segundo o musicólogo italiano Enrico Fubini (2007), "o melodrama implica necessariamente um acompanhamento musical que

21 Os caracteres diziam respeito à composição da hierarquia social das personagens, fosse um rei, um pastor ou um deus. Cada uma possuía suas vestimentas, seus modos de agir e de se comportar, de acordo com a sua origem e lugar social. 
permita e favoreça uma sucessão temporal dos diálogos e da ação dramática” (p.163), o que trouxe diversas reflexões musicais, filosóficas e estéticas, além de questões matemáticas e acústicas, que, nesses dois séculos, em meio às transformações sociais, foram se sistematizando em conceitos e categorias filosóficas. Dele são ainda estas palavras:

[...] nasce um novo interesse pela música, sobretudo pelo melodrama, o espetáculo verdadeiramente mais popular do século; o número de pessoas interessadas de algum modo pela música cresceu vertiginosamente e, não obstante a aparente contrariedade, aumentou paralelamente a consideração dos homens de cultura em confronto com a música e de todos os problemas a ela relacionados. ( p.2, tradução nossa)

O entrelaçamento entre harmonia e melodrama mudou as relações entre música e texto, contrastando com o período anterior, o Renascimento, no qual a textura polifônica, com a sobreposição de vozes, era diferente da nova melodia acompanhada. Diante dessa nova maneira de utilizar a linguagem verbal, a música conseguiu, enfim, se estabelecer como espetáculo, com aspectos teatrais. $\mathrm{O}$ apoio da harmonia permitiu que a melodia, constituída pelo texto da poesia, se impulsionasse numa linguagem dos afetos, cujos efeitos sobre o espectador eram direcionados através de um discurso como uma linha contínua e fluida. ${ }^{22}$

A linguagem dos afetos, com a finalidade de provocar efeitos sobre os espectadores, era conseguida pelo conhecimento cientí-

22 Para Fubini (2007, p.164), o surgimento da harmonia com frequência é associado ao surgimento da ciência moderna, o que, no século XVII, fez que os fundamentos filosóficos da harmonia fossem questionados, como haviam feito Descartes, Mersenne e Leibniz. Entre a harmonia e a ciência moderna havia afinidades formais, entre elas, o espírito racionalista e uma explicação simplificada e racional de um mundo ordenado por leis fundamentais. Um exemplo dessa simplificação no século XVI é a redução dos modos em maior e menor, como encontrado em Zarlino. Começou, assim, uma racionalização do universo sonoro. 
fico da natureza da música e provocava movimentos no espírito do ouvinte. O que se pretendia com a ópera, e também com os instrumentos musicais, era mover os afetos, direcionando o público para o choro ou o riso, para a comoção. Através da racionalidade, o músico conseguiria, pelas regras, fazer uma previsão calculada da eficácia do discurso musical, em que a razão conduziria o coração para os sentimentos desejados, associados à esfera cênica e à poesia, e promoveria o espetáculo musical do qual o ouvinte seria convencido e com o qual se sentiria comovido.

Além disso, o espetáculo da ópera contava com o respaldo dos instrumentos musicais. A música instrumental, no decorrer do século XVII, exerceu influência nas árias, nos duetos e nos coros operísticos, além de ter sido usada nas aberturas, conseguindo, assim, certa independência da música vocal. ${ }^{23}$ Esse desenvolvimento instrumental independente do campo vocal, único significado válido até então, configurou-se como uma fratura geradora de discussões, no início do século XVIII, sobre os significados da música, mais ainda sobre os da música instrumental.

Pensava-se que a música deveria mover os afetos, expressar emoções e possuir significados. A dúvida era se a música instrumental também carregava significados, já que não tinha o mesmo elemento racional contido na palavra e, sem ela, sua capacidade de imitar estaria prejudicada e não satisfaria as regras exigidas para a imitação da natureza. Entretanto, a linguagem verbal gozava de privilégio, e assim, até os finais do século XVIII, pensava-se que a música instrumental pura era insignificante, sem autonomia. Mas na discussão sobre ópera que se instaurou no começo do século XVIII, além das questões vinculadas à música instrumental, outras investigações foram feitas envolvendo as noções de arte e belo, ${ }^{24}$

23 Entre as formas instrumentais desenvolvidas a partir da música instrumental estão as sonatas, os concertos para instrumentos solistas e os concerti grossi.

24 Para Aristóteles (Poética, VII, 1450b 35; Metafísica, XIII, 3, 1078b 1), "o belo consiste na ordem, na simetria e numa grandeza que se preste a ser facilmente abarcada pela visão em seu conjunto que retoma e adota a teoria da arte como imitação" (in: Abbagnano, 2007, p.367). 
como o conceito de gosto, ${ }^{25}$ vinculado à ideia de imitação, apresentado nas discussões sobre ópera analisadas neste livro.

O melodrama, do qual se constituiu a ópera, foi o símbolo da união entre músicos e literatos, e também motivo de muitas discórdias entre eles. Desde o Renascimento, os olhos se voltaram para a Antiguidade Clássica, da qual eram retirados os modelos imitativos para o fazer musical, e a música como espetáculo, como representação, ${ }^{26}$ voltou-se para a tragédia antiga.

A ópera deixou profundas marcas no meio musical, pois, ao se vincular à poesia e ao teatro, pôde fazer jus às origens antigas, apropriando-se dos mitos $^{27}$ gregos como modelos poéticos transformados em música, legitimando essa nova música como espetáculo

25 O conceito de gosto, segundo Abbagnano (2007, p.367), é entendido como a faculdade de discernir o belo, dentro e fora da arte. A partir do século XVIII, a arte e a beleza serão vinculadas, como objetos de uma única investigação.

26 Representação, nesse contexto, além de apresentação de uma peça teatral ou operística, tem também o significado de representação social, já que a aristocracia - os nobres franceses dos séculos XVII e XVIII - pensavam que a tragédia deveria representar personagens de hierarquias sociais elevadas e se viam representados nas apresentações de teatro e ópera da época. Eles se identificavam com essas personagens, assistindo, assim, à imitação do seu status social e poder no palco. Abbagnano (2007, p.853) afirma que representar tem vários sentidos: designa-se com esse termo aquilo por meio do qual se conhece algo e, nesta acepção, o conhecimento é representativo, e representar significa ser aquilo com que se conhece alguma coisa; por representar entende-se também conhecer alguma coisa, e após este conhecimento conhece-se outra coisa - a imagem representa aquilo que é imagem, no ato de lembrar; por representar entende-se ainda causar o conhecimento, do mesmo modo que o objeto causa o conhecimento. No primeiro caso, a representação é a ideia no sentido mais geral, no segundo, é a imagem e, no terceiro, é o próprio objeto. Esses são, na realidade, possíveis significados do termo, que voltou a ter importância com a noção cartesiana de ideia como "quadro" ou "imagem" da coisa.

27 O mito tem relação com os acontecimentos históricos. Através de sua linguagem, transformada em ação trágica teatral, a ópera transformava esse mito num acontecimento renovado. A música permite reconhecer essa linguagem, ao transformar esse acontecimento em ação atual. Segundo Fubini (2007, p.172), o melodrama não é mais do que a tentativa de restaurar essa linguagem mais primitiva, originária do homem, de reconduzir a humanidade à expressão de uma unidade perdida, ainda que sob a égide da linguagem verbal. 
e representação, constituindo-se numa ação trágica, usando personagens elevadas da aristocracia ou figuras de deuses, de heróis que passavam da felicidade para a infelicidade, produzindo a catarse, que eram os sentimentos de terror e piedade vivenciados ao mesmo tempo, provocando esses efeitos na audiência, como se propunha esse gênero. Para isso se valeu da mimese, ou imitação. ${ }^{28}$ Essa nova forma de representação surgida no século XVII se relacionou com os fenômenos históricos de seu tempo e com a tradição clássica.

$\mathrm{Na}$ ópera, o cantar poderia mover os afetos, pois se esperava desse gênero uma imitação das paixões humanas existentes na natureza. As ações tinham sua regularidade estabelecida pelo gênero poético da tragédia clássica e da tragédia do teatro clássico francês do século XVII. A ópera era potencializada não só pelos aspectos cênicos, teatrais, mas principalmente pela expressão musical, exercendo então um papel que lhe era próprio. A eficácia do movimento dos afetos estava ligada à dimensão teatral e espetacular conferida à música que, absorvendo a linguagem verbal, modificou a concepção de tempo e lugar do espaço cênico.

Mas a relação entre melodia e harmonia, música vocal e instrumental trouxe diversos debates estéticos no decorrer do século XVIII, principalmente entre França e Itália, já que foi grande a incidência das óperas bufas em Paris. Os debates não focaram somente os aspectos musicais, mas também as regras imitativas, a real capacidade da música em imitar os elementos cênicos, as personagens elevadas e baixas nas óperas.

A insistência em manter uma tradição clássica quando esta começava a se tornar desconhecida de um novo público emergente,

28 Pelo conceito de imitação, de acordo com o viés aristotélico, a arte deriva do valor do objeto imitado. A tragédia imitava os mitos, e todo objeto imitado pertence a esse gênero. Ao imitar o mito e seus caracteres, assegura-se a produção de uma boa tragédia. Cabe ao artista o mérito da escolha oportuna do objeto imitado e, quando escolhido, este não deve mais do que ser reproduzido, com suas características. Pouco importa se o objeto imitado é algo natural ou uma entidade transcendente ou inteligível: a passividade da imitação permanece (cf. Abbagnano, 2007, p.379). 
como fora a classe burguesa, trouxe mudanças no que se refere à ideia de gosto. Toda essa discussão envolvendo filósofos e homens de letras contemplou diversas tomadas de posição em meio às transformações sociais que aconteciam dentro do absolutismo francês.

Quanto aos debates estéticos, Enrico Fubini (2007) escreveu:

A perspectiva global em que se inseriu a disputa estética, tanto na Itália como na França - países em que, durante mais de dois séculos, o melodrama foi o eixo sobre o qual girou a vida musical -, contou com um ponto significativo: o representado, primordialmente, pelo inoportuno problema das relações [entre] música-poesia [...]. Esta cadeia de problemas, que amiúde se faz camuflada, de múltiplas formas, através das polêmicas, das numerosas querelles dos séculos XVII e XVIII, se reduz, em definitivo, a um problema muito mais amplo, que se situa acima dos demais: o problema da coexistência de duas linguagens tão distintas, a verbal e a musical, não só por sua diferente entidade semântica, mas por suas características gramaticais e sintáticas específicas. (p.175, tradução nossa)

As relações entre música e poesia conduziram as propostas de classificação em torno da música italiana e da francesa. Temas como a desvalorização da música instrumental foram questionados pelos homens doutos da época, e a ópera ocupou o ponto mais alto nessa hierarquia. Mesmo questionada pelos filósofos e teóricos, conseguiu afirmar-se cada vez mais no meio social e não só na camada aristocrática, mas também na burguesa.

A poesia, com um conteúdo conceitual e didático, dirigia-se à razão e permitia a aproximação do espetáculo trágico. A linguagem da razão era a única válida para o homem e capaz de demonstrar a realidade. A música, por sua vez, ocupava um lugar inferior, pois, segundo a concepção da época, dirigia-se somente aos sentidos, sendo desprovida de significados. Para que tivesse significados e de alguma forma expressasse também a realidade, orientava-se pela linguagem verbal, pois a música só podia ser admitida se, como nas 
artes em geral, servisse às verdades racionais. Por conta do elemento racional, a poesia tinha supremacia sobre a música.

A linguagem da poesia era vinculada à razão, e a da música, à sensibilidade e ao sentimento. Uma era verbal, e a outra, sentimental. Do ponto de vista teórico e filosófico, suas relações foram estreitadas e aprofundadas, mas elas também mostraram antagonismos. Essas relações, encontros, convivências entre as duas linguagens, no que concerne aos antagonismos demonstrados pelas querelas entre opera seria e ópera bufa, pela discussão sobre a música instrumental, tinham, na verdade, a preocupação de reconduzir, em certa medida, as relações entre música e poesia.

A condenação do gênero dramático deu-se porque a ópera não seguia os preceitos da verossimilhança teatral. Exigia-se dela maior racionalidade, já que constituía um elemento fundamental na cultura e na vida social. Entre os séculos XVII e XVIII, a polêmica ainda era de fundo moral. A música era considerada apenas um deleite para os ouvidos e, ao atender somente aos aspectos emocionais, não cumpria a sua função, ou seja, não contribuía para refinar os costumes, o que só era possível através da racionalidade. Daí a exigência da junção da música com a linguagem verbal, para que a razão fosse orientada para o aperfeiçoamento moral. A mentalidade era a racional cartesiana, e para esse pensamento não existia relação entre poesia e música. Ambas caminhavam em direções opostas, já que a poesia era a expressão da razão, e a música, a dos sentidos, devendo servir de instrumento para realçar e valorizar a razão.

Perante esse quadro de relações entre música e poesia, em que a primeira, segundo a concepção da época, tinha a função de valorizar a segunda, surgiram as primeiras polêmicas quanto às questões estéticas na música. Ao falar de música, falava-se, na verdade, de literatura, pois eram os aspectos da tragédia que na verdade se refletiam na música de ópera, o que era ou não correto em seu contexto. Os julgamentos sobre ópera em certa medida eram, na verdade, os julgamentos sobre a condução da tragédia e sua estrutura. $\mathrm{O}$ bom gosto em música se orientava por essa estrutura, tornada tradicional, e quando algum de seus aspectos não era satisfeito na execução 
da ópera ou não provocava o efeito racional esperado, um problema era identificado. Em maior ou menor medida, as discussões sobre ópera se ligavam a essa relação entre música e poesia.

A primeira polêmica, notadamente estética, ocorreu entre os anos de 1702 e 1704, entre o abade francês François Raguenet (1660-1722) e Jean Laurent Lecerf de La Viéville (1674-1707). Raguenet, depois de uma viagem à Itália, encantado com a música que ouviu nesse país, escreveu o Paralele des Italiens et des François en ce regarde la musique et les opéra [Paralelo entre italianos e franceses no que concerne à música e às óperas], e nesse texto reconheceu que, do ponto de vista literário, as óperas italianas eram pobres em comparação com as francesas, mas a musicalidade delas era preferível à das francesas.

Em relação aos aspectos literários da ópera, Raguenet (1702) afirmou:

Nossas peças de teatro, sobre as quais os músicos trabalham, estão muito acima das dos italianos: são peças regulares e contínuas. Se apenas declamássemos as palavras, sem cantá-las, elas agradariam tanto quanto outras peças de teatro que não são cantadas. Nada é mais espiritual do que os diálogos que lá se encontram; nelas, os deuses falam com toda a dignidade de seu caráter; os reis, com toda a majestade de sua condição; os pastores e pastoras, com o terno gracejo que lhes convém. Amor, ciúmes, furor e outras paixões são tratadas com arte e delicadeza infinitas e há poucas tragédias ou comédias mais belas do que a maior parte das óperas que Quinault ${ }^{29}$ fez. (p.1, tradução de Paulo Mugayar Kühl)

Do ponto de vista literário, as óperas francesas, segundo Raguenet, poderiam ser declamadas sem música, pois seus textos, por si

29 Philippe Quinault (1635-1688), poeta, dramaturgo e libretista francês, colaborou com Jean-Baptiste Lully em treze obras. Suas obras são constantemente citadas como modelo a ser seguido, especialmente por autores italianos que desejavam dar maior unidade às óperas italianas. 
mesmos, possuiriam toda uma coerência, como uma peça de teatro. Elas seguiam as exigências de constituição das tragédias teatrais. Nesse aspecto, a ópera italiana era pobre, reconhecendo-se assim na cultura francesa grande maestria literária. Porém, a musicalidade das óperas e da música italiana possuía uma inesgotável inventividade, em comparação com a musicalidade francesa:

Como os italianos são muito mais vivos do que os franceses, eles são muito mais sensíveis às paixões e também as exprimem muito mais vivamente em todas as suas produções. Se é necessário fazer uma sinfonia que exprima a tempestade, o furor, eles imprimem tão bem o caráter disso em suas árias que, com frequência, a realidade não age fortemente sobre a alma. Lá tudo é tão vivo, tão agudo, tão penetrante, tão impetuoso e tão inquieto que a imaginação, os sentidos, a alma e o próprio corpo são conduzidos por um enlevo coletivo. Não podemos nos impedir de seguir a rapidez desses movimentos. Uma sinfonia de fúrias agita a alma, revira-a, derruba-a, apesar dela. $\mathrm{O}$ violinista que a executa não pode evitar de ser por ela transportado e de sentir o furor: atormenta seu violino, seu corpo, não é mais senhor de si, agita-se como um possuído e não poderia fazer de outra forma. (Raguenet, 1702, p.7)

Nesse fragmento de texto, o elemento musical foi tratado como autônomo, independente da poesia e da razão, agindo, de acordo com a concepção da época, de maneira descontrolada sobre os sentidos, já que os músicos eram tomados por uma agitação provocada pela música. A descrição dos efeitos da música instrumental, como os da sinfonia, exemplo usado posteriormente por Dubos e Batteux, assim como por outros autores, demonstrou que o prazer da sua música estava vinculado aos sons em si, por atuar nos sentidos, transgredindo a exigência de satisfazer a razão, algo impensado quanto aos efeitos esperados da música nesse período. Apesar de Raguenet também reconhecer que a música seria um divertimento estranho à razão, deixou-se levar ao sabor das sensações por ela produzidas. 
A música instrumental a que ele se referiu nesse trecho do seu Paralelo não possuía vínculos com as exigências das regras das teorias imitativas. Ele apenas demonstrou que essa música arrebatava os sentimentos pelos sons em si, sem os aspectos racionais formais fortemente arraigados no início do século XVIII.

Raguenet preferia a música italiana porque esta, do seu ponto de vista, era mais agradável do que a música francesa, mais expressiva, mais melódica e brilhante. A música italiana, no sentido dramático, já que a sua literatura apresentava problemas de linearidade e equilíbrio, poderia não ter sido concebida segundo as regras estritas de imitação da natureza, mas admitiu que sua beleza estava acima das regras dramáticas e literárias, devido à sua inesgotável criatividade e musicalidade, em comparação com a ópera francesa. Os italianos não se importavam muito, como ocorreu posteriormente com a ópera bufa, com a mistura de estilos, pois misturavam personagens de tragédia e de comédia numa única obra, algo impensável para o gosto francês.

A língua francesa era o elemento de maior orgulho para a nação, que tinha no aspecto racional a compreensão e o aprendizado dos costumes, assim como sua moralização, e só o aspecto verbal promoveria isso. Além da música, Raguenet (1702) ainda fez críticas à língua francesa, salientando as vantagens da língua italiana:

A língua italiana tem uma grande vantagem sobre a francesa para ser cantada, pois todas as suas vogais soam muito bem, enquanto a metade das de língua francesa são vogais mudas, que quase não têm som. De onde, primeiramente, acontece de não sabermos fazer nenhuma cadência nem passagens ornamentadas agradáveis sobre as sílabas em que se encontram tais vogais. E, em segundo lugar, só ouvimos as palavras pela metade; de modo que é necessário adivinhar a metade do que cantam os franceses e que, ao contrário, ouvimos muito distintamente tudo o que dizem os italianos. Além disso, mesmo que todas as vogais da língua italiana soem perfeitamente bem, os músicos ainda escolhem aquelas que melhor se ouvem para fazer suas mais belas passagens ornamen- 
tadas. É sobre a vogal a que eles fazem quase todas. E nisso têm razão, pois essa vogal, sendo a de um som mais claro, a beleza das passagens ornamentadas aparece mais. Enquanto os franceses as fazem indiferentemente sobre todas as vogais, sobre as mais surdas como sobre as mais sonoras [...] (p.5)

Segundo o autor, a escolha da vogal para fazer a ornamentação tornava a música italiana mais musical e criativa do que a francesa, além de inteligível. O autor demonstrou assim sua preferência pelo caráter meramente agradável da música italiana. Burlou, assim, aquilo que seria do agrado do gosto francês, buscando apenas a satisfação dos sentidos, e não da razão. Sobre a questão de considerar a língua italiana mais apropriada ao canto, já que pensava não ser a francesa condizente com essa arte, isso prejudicaria a compreensão dos significados das palavras na música, que se ancorava na linguagem verbal. Questionou-se assim seu poder racional. Como a língua francesa poderia ser adequada à ópera se ela trazia problemas de compreensão para o canto? Os aspectos racionais e significativos, tão caros aos franceses, se incompreensíveis, estariam prejudicados, e na própria língua deles.

Essas digressões abalaram o pensamento vigente na época, e posteriormente se tornariam constantes as exigências literárias, como satisfação da razão na composição das óperas, de realizar a imitação seguindo as regras da teoria da verossimilhança, do próprio racionalismo. Com Raguenet, os sentidos ganharam uma valorização superior à razão. Mas ele recebeu uma resposta de Lecerf, defensor da tradição francesa em relação à ópera.

Diante desse paralelo entre a música italiana e a francesa, Lecerf de La Viéville publicou, em 1704, sua Comparaison de la musique italienne et de la musique françoise [Comparação da música italiana e da música francesa], para rebater o Abade Raguenet. Sua Comparação procurou estabelecer, por meio de diálogos fictícios entre três interlocutores, as regras do bom gosto francês. Ele era um conservador moderado e propôs um meio-termo, o moderado com 
relação ao bom gosto, como ideal e justo. Para ele, a simplicidade e a naturalidade eram as regras fundamentais para o equilíbrio musical e deveriam ser constantemente observadas. Evitar os excessos, desprezar o supérfluo, eis o que condizia com o bom gosto. No seu rebate contra o Paralelo de Raguenet, ele acusou os italianos de se deixarem levar pelo mero prazer produzido por um belo som, de se deixarem seduzir, na verdade, pelos sentidos.

Para o gosto francês, a música italiana era símbolo de "mau gosto”, pois chocava o coração, não o ouvido. Pela perspectiva racional, a ópera primeiramente era captada pelos ouvidos e compreendida pela razão. Seus modelos, retirados da natureza, eram reconhecidos e avaliados segundo as regras imitativas, verificando-se se a verossimilhança havia sido alcançada com sucesso. Só depois disso os efeitos passionais eram promovidos, de maneira controlada, pois a tragédia e, em consequência, a ópera eram um deleite para as paixões humanas, o objeto de sua finalidade. Por isso o choque para o coração era mais nefasto do que para o ouvido. Por esses motivos. Lecerf achava que os italianos forçavam demais o uso dos instrumentos musicais, adornavam em excesso as melodias de suas árias, o que chocaria o coração, segundo sua concepção francesa de gosto.

Sobre os usos da língua francesa e italiana, Lecerf (1704) se expressou da seguinte maneira:

Ce sont des paroles Italiennes, comme vous voyés, et cependant Lulli n'a pas daigné les embellir du moindre petit roulement: tant ce Musicien fécond et original faisoit peu de cas de ces sortes d'agrémens. Un homme d'esprit que vous connoissés tous deux, et qui sçait bien la Musique, dit là-dessus plaisamment, qu'il en est des Musiciens amateurs et faiseurs de doubles et de passages, comme des mauvais Cuisiniers qui tâchent de se saver par le sel et par le poivre. Pour moi, dit la Comtesse, j'en étois autresois folle; mais il me semble que je ne les aime plus tant à présent... C'est, Madame, que vôtre bon goût s'est bientôt lassé de ces beautés fausses, qui ne charment que des Musiciens novices ou gâtés. J'espere 
que vous remettrés en cela Monsieur le Comte dans le bon chemin, comme vous avés déja fait en bien d'autres choses.

La prononciation distincte est le second avantage que Monsieur l'Abbé R. attribuë à la langue et aux chanteurs Italiens. Je me garderai bien de lui passer celui-là. Tout au contraire. Je soûtiens que les Chanteurs Italiens prononcent mal, et même qu'ils ont beaucoup moins de facilité, que les nôtres, à bien faire entendre ce qu'ils disent. Pourquoi, Monsieur, dit la Comtesse? Premierement, Madame, parce que les Chanteurs Italiens serrent tous les dents et n'ouvrent point assés la bouche: excepté dans leurs roulemens, où ils la tiennent ouverte des quarts-d'heure entiers, sans remuer la langue, ni les lévres. Mais quand ils récitent, quand ils disent quelque chose, ils ne l'ouvrent point. On croiroit que ce n'est rien que de bien ouvrir la bouche. Cependant c'est là un défaut naturel et commun à tous les Chanteurs du monde, comme ne pas tourner assés les piés est le défaut de presque tous les Danseurs. Il n'y a qu'en France où l'on sçache ouvrir, comme il faut, la bouche en chantant. Tous les autres Peuples, sans exception, manquent en cela: les Italiens autant et plus que les autres. Et par conséquent il faut que leurs Chanteurs prononcent moins distinctement que nos François. J'entens que nos François qui ont eu de bons Maîtres, et qui sçavent chanter.

Reste à vous montrer qu'on entend et qu'on comprend les paroles Italiennes avec plus de difficulté que les nôtres. Ce sont des Vers qu'on chants. Or leur Poësie aime les élisions, et en est toute remplie. Ce qui fait que plusieurs sillabes étant mangées et confonduës les unes dans les autres: le discours devient nécessairement obscur, et le sens difficile à attraper, quand le Musicien chante, et chante vite. $(\mathrm{p} .13)^{30}$

[São as palavras italianas, como vedes, e contudo Lully não se dignou a embelezá-las nem mesmo na menor passagem, tanto

30 Nesse texto em francês, como em muitos outros, foi mantida a escrita da época, sem adaptações para a escrita do francês moderno. 
que esse músico fecundo e original fez pouco caso desses tipos de consentimentos. Um homem de espírito que vós conheceis, e que conhece bem a música, disse, de modo gracioso, que existem músicos amadores e realizadores de doubles ${ }^{31}$ e de passagens, como os maus cozinheiros que se obrigam a degustar pelo sal e pela pimenta. Para mim, diz a Condessa, eles estavam loucos; no entanto, hoje em dia, eu não os aprecio tanto... Madame, é que vosso bom gosto rapidamente se cansou das falsas belezas, que encantam apenas os músicos novatos ou caprichosos. Espero que a senhora reconduza o senhor conde no bom caminho, como já o fez com tantas outras coisas.

A pronúncia distinta é a segunda vantagem que o senhor Abade R. [Raguenet] atribui à língua e aos cantores italianos. [...] Eu sustento que os cantores italianos pronunciam mal, mesmo que eles tenham muito menos facilidade do que os nossos em escutar o que dizem. Por que, senhor?, pergunta a Condessa. Primeiramente, madame, porque os cantores italianos cerram todos os dentes e não abrem muito a boca, exceto em seus roulemens, ${ }^{32}$ em que eles a mantêm aberta um quarto de hora inteira, ${ }^{33}$ sem mexer a língua, nem os lábios. Mas, quando recitam, quando dizem alguma coisa, não a abrem em absoluto. Acreditamos que seja apenas um abrir a boca. Entretanto, isso é um defeito natural e comum a todos os cantores do mundo, assim como não girar os pés é um defeito de quase todos os dançarinos. Somente na França sabe-se abrir a boca cantando

31 "O segundo couplet (voz aguda) de uma canção quando são feitas diminuições nela" (Dictionnaire de l'Académie française, 1.ed., 1694). Em termos de música, denomina-se le double d'un air a mesma ária que ocorre numa figura simples por adição de muitas notas que fazem variar e adornar o canto, como Le double des Folies d'Espagne (Dictionnaire de l'Académie française, 4.ed., 1762).

32 Roulement é o movimento do rulo. É expressão de vários tons diferentes numa mesma expiração. Hoje seria como o rulo em percussão, ou mesmo um som semelhante à produção de trinado na voz quando se canta (cf. Dictionnaire de l'Académie française, 1.ed., 1694).

33 Um quarto de hora inteira, nesse contexto, não faz referência à duração do tempo, mas sim ao formato da boca, aberta ao extremo, num ângulo de 90 graus. 
como deve ser. Todos os outros povos, sem exceção, falham nisso, e os italianos, muito mais do que os outros. E, em consequência, é necessário que seus cantores pronunciem menos distintamente do que os nossos franceses. Eu penso que os nossos franceses é que tiveram bons mestres e sabem cantar.

Resta a vós mostrar que escutamos e compreendemos as palavras italianas com mais dificuldade do que as nossas. São os versos que cantamos, pois sua poesia ama as elisões e tudo é preenchido, o que faz que várias sílabas sejam engolidas e confundidas umas com as outras. O discurso torna-se necessariamente obscuro e o sentido difícil de apreender quando o músico canta, e canta rápido.] (Tradução nossa)

Lecerf defendia a tradição racionalista e a classicista, encarnadas em sua noção de bom gosto, e também mostrou-se favorável ao formato do melodrama estabelecido a partir de Lully. Para ele, observar e seguir as regras estabelecidas era a maneira mais sensata de compor, executar e apreciar a música, e nelas se encontraria o meio-termo, o ponto ideal para julgar as artes, possível apenas mediante a razão. As regras evitariam os excessos na música, assim como a falta dos elementos necessários para a sua realização e contemplação.

Já Raguenet, amante da música italiana e do "bel canto", ${ }^{34}$ considerou suas inflexões pessoais, sua própria apreciação pessoal no julgamento estético da música. Julgava seu valor a partir dos próprios sentimentos, e não pelo fato de ela se conformar ou não à linguagem verbal, cuja posição, na concepção racionalista, era sempre superior à da música. Ao aceitar e defender uma música, principalmente a instrumental, sem o respaldo das teorias imitativas e das regras dramáticas, reconhecia a sua autonomia, contrariando as exigências da época. Sem esse respaldo, considerado necessário para julgar

34 Bel canto é expressão geralmente usada para se referir ao elegante estilo vocal italiano dos séculos XVII a XIX, caracterizado pela beleza do timbre, pela emissão floreada, pelo fraseado bem feito e pela técnica fácil e fluente (cf. Sadie, 1994, p.90). 
a música, o único juiz que restava para fazer isso era o ouvido e, neste caso, ele não tinha sido "educado" para reconhecer o lugar que a música deveria ocupar no contexto literário, já que a escuta mediante regras era uma escuta literária.

Havia, portanto, nessa primeira polêmica no início do século XVIII envolvendo a música italiana e a francesa, uma espécie de disputa, uma batalha em duas frentes: de um lado estava Raguenet, mais progressista, considerando o ouvido e a sensibilidade, sem seguir as regras; de outro estava Lecerf, conservador, que defendia a razão e o intelecto, os quais definiriam o bom gosto, avaliado segundo os moldes da tradição da Antiguidade Clássica e do teatro clássico francês do século XVII.

Como resposta à Comparação feita por Lecerf, Raguenet escreveu, em 1705, sua Défense du parallele des Italiens et des François [Defesa do paralelo entre italianos e franceses], artigo em que tentou rebater Lecerf a respeito de sua afirmação de que os italianos pronunciavam mal a sua língua no canto:

C'est ici une Avanture, Messieurs! voilà le Cartel de Monsieur le Chevalier affiché, et il déclare qu'il est prest à soutenir contre tout venant, que les Chanteurs Italiens prononcent mal. Voyons comment il s'en tirera. [...]

Voilà, par exemple une de ces fautes qu'on ne sauroit mettre sur votre compte sans injustice: Pour tout autre, il n'en seroit pas de même; et si un homme, sans avoir jamais été en Italie et sans avoir jamais entendu chanter les Italiens comme vous, venoit dire, Je soutiens, Madame, que les Chanteurs Italiens n'ouvrent point assez la bouche en chantant, on seroit en droit de lui dire qu'il y a plus que de la témérité à soutenir une pareille chose sans l'avoir vuë: Mais pour vous, Monsieur le Chevalier, et pour les autres Chevaliers vos Confreres, il seroit ridicule d'exiger que vous vous donnassiez la peine d'aller bien loin pour voir les choses dont vous voulez parler, puisqu'en quelque part du monde que vous soyez, vous ne voyez jamais que ce qui est dans votre imagination. Vous vous êtes donc imaginé en Normandie que les Chanteurs Italiens, 
que vous n'avez jamais entendu chanter, serrent tous les dents en chantant; et c'est, pour vous, comme si vous aviez vû la chose sur les lieux mêmes; ainsi quoique les autres François, d'abord qu'il arrivent en Italie, commencent par reprocher aux Chanteurs de ce pays-là qu'ils ouvrent excessivement la bouche en chantant, [...]; on ne prétend point que vous ayez fait aucune faute en disant qu'ils ne l'ouvrent pas assez, et qu'au contraire, ils serrent tous les dents en chantent, tellement que voilà déja une méprise de rabatuë à votre profit sur cet endroit; voyons-en la suite. (p.22)

[Isto aqui é uma aventura, senhores! Eis o cartaz de Monsieur le Chevalier afixado, e ele declara que está prestes a defender, contra todos, que os cantores italianos pronunciam mal. Veja como ele se sairá. [...]

Eis, por exemplo, uma daquelas faltas que não conseguiremos colocar na sua conta sem injustiça. Por outro lado, não seria o mesmo se um homem, sem jamais ter estado na Itália e nunca ter escutado os italianos cantarem, como vós acabais de dizer. Eu afirmo, madame, que os cantores italianos não abrem muito a boca quando cantam. Teríamos o direto de lhe dizer que é muito temeroso sustentar uma coisa semelhante sem ter visto. Porém, de vós, Monsieur le Chevalier, e de todos os demais cavaleiros confrades, seria ridículo exigir que vos désseis ao trabalho de ir mais longe para ver as coisas as quais quereis falar, pois em qualquer parte do mundo em que os senhores estejam, jamais vereis o que se encontra em vossa imaginação. Portanto, imaginastes na Normandia que os cantores italianos, os quais o senhor nunca ouviu cantar, cerram todos os dentes quando cantam. É, para vós, como se o senhor tivesse visto a coisa em seu próprio lugar. Assim, quaisquer outros franceses, chegando primeiramente na Itália, começam a reprovar os cantores desse país porque eles abrem excessivamente a boca enquanto cantam [...]. Não pretendemos dizer que cometestes uma falta dizendo que eles não abrem muito [a boca]. Ao contrário, eles cerram os dentes quando cantam, de modo que esta já é uma confusão de pouco proveito nesse assunto.] (Tradução nossa) 
Enrico Fubini (1993, p.115) ressaltou que Raguenet e aqueles que pensavam como ele não tiveram, na época, grandes armas para atacar seus adversários, já que o ouvido não podia se defender enquanto não encontrasse razões para isso. Não havia espaço para deixar o gosto se moldar pelas próprias sensações diante do fazer musical.

Para Lecerf, a música que se dirigisse exclusivamente aos ouvidos e aos sentidos com a finalidade de agradar a eles era algo impensável. Seus efeitos eram um mal que se deveria reduzir ao máximo. Para diminuir os males provocados apenas pelo mero saborear agradável da música - e ele sabia da impossibilidade de não se deixar envolver apenas pelo som em si-, aconselhava o meio-termo. A moderação era o melhor meio, pois se, de um lado, uma música pobre em ornamentação era considerada um defeito para o ouvido e a razão, o contrário também era um problema: o excesso de ornamentação gerava confusão onde a razão não encontrava compreensão. As regras permitiriam o meio-termo nessa questão.

Sobre a posição de Raguenet e Lecerf nessa polêmica, Fubini (2007) comentou:

Lecerf e Raguenet se posicionam como antípodas. Apesar de coincidirem um com o outro nas análises sobre os acontecimentos, diferem quanto ao modo de valorizá-los. Ambos reconhecem que a música não é senão uma agradável diversão estranha à razão e, por conseguinte, inferior - a partir de tal abordagem - a artes que apelam à razão e ao espírito. Assim mesmo, ambos julgam que a ópera francesa é claramente superior à italiana do ponto de vista literário e dramático. Agora, Raguenet é aficionado pelo bom gosto, [aquele] que viaja e aprecia tudo quanto lhe agrada, antecipando-se assim à atitude crítica adotada por muitos iluministas, livre e despreocupado; Lecerf, em contrapartida, simboliza o tipo de homem que se deixa guiar pela razão, ou, o que é a mesma coisa, pela erudição: não podendo eliminar o nível fatual da música, que a razão rejeita por direito, se engendra como lhe é possível para que ela se volte ao razoável. (p.181, tradução nossa) 
Lecerf usava e defendia o princípio da autoridade para validar seus pensamentos e argumentos, alegando que, se fosse válido, o gosto do rei deveria ser aquele a ser seguido. A razão, em conjunto com a tradição e a racionalidade, era a autoridade usada como arma por ele nessa batalha, a qual venceu. Num período em que a imitação era regida pelo racionalismo, Raguenet, livre e despreocupado perante o bom gosto que encontrava em suas viagens, defendeu seus sentimentos e suas emoções, e comparava os italianos e os franceses usando como critério o seu gosto pessoal, e não os modelos imitativos que seguiam as regras. Usar como argumento o próprio gosto pessoal era algo que ainda não tinha espaço na época em que se iniciaram essas discussões. Seus princípios eram as suas próprias sensações. O certo é que existia uma tensão entre o ouvido e a razão e, no caso do ouvido, ele ainda precisava da razão para se fazer valer.

Por detrás dessas discussões sobre ópera havia a condenação dela no campo moral, mais do que no estético. Condenar a ópera francesa, categorizando-a como inferior à italiana, era considerá-la menos eficaz e mais deficiente na representação e no aperfeiçoamento dos costumes. Na representação da ópera, ela não só demonstrava se as regras relativas às teorias imitativas estavam sendo devidamente cumpridas, de acordo com a tradição oriunda da Antiguidade Clássica e do teatro clássico francês do século XVII, mas expressava também os ideais aristocráticos da sociedade francesa em torno da realeza, que desejava ver no palco a representação de seus costumes e comportamentos. Por esse motivo, a função da ópera, como também a do teatro, era a de educar, ensinar os costumes, a boa conduta, e por isso discutir a imitação e o gosto significava discutir os seus aspectos morais.

Em seus argumentos em defesa da música francesa, Lecerf recorreu ao amor universal. Outros autores também recorreram a ele, pelo viés de uma ética religiosa. Com esse amor universal, ele intentava impor determinados limites ao prazer universal, com traços e características que validassem seu atrativo como razão.

Outra crítica feita por Raguenet à música francesa era relativa à sua monotonia, já que ele via na música italiana grande vivacidade 
e variedade de sentimentos, agradáveis ao seu espírito. A defesa de Lecerf da música francesa e, em consequência, do classicismo e do racionalismo francês se fazia no sentido de que, por ser essa música simples e clara, a razão se identificava com ela. A ópera francesa era tida como monótona devido à concepção, na época, de uma natureza sempre igual, a ser imitada. As óperas francesas seguiam esse pressuposto e, por isso, muitas vezes elas foram consideradas repetitivas.

A monotonia era uma qualidade, um valor perseguido pelos franceses. Ela representava a linearidade da razão e orientava a imitação na música. A natureza se mostrava sempre do mesmo modo, regular no tempo e no espaço, apesar das transformações que ocorriam em seu seio. Nesse sentido, a busca da monotonia representava a busca da razão.

Ela se mostrava regular como condição do pensamento e da realidade, o que era indispensável para a observação e a imitação dos objetos da natureza numa única representação, como uma pintura. Esses objetos, embora sempre determinados, na imitação se multiplicavam, assumindo diversas formas. Monotonia também significava pouca mobilidade em meio às hierarquias sociais: cada estrato social permaneceria sempre igual e no mesmo lugar. Essa estrutura social com todos os status bem definidos era o material literário usado nos textos das representações de ópera, com a função de aperfeiçoamento dos costumes e produção de efeitos morais nos espectadores.

Ainda segundo Lecerf, a música como arte era apenas um artifício que se opunha à natureza, por ser um produto da fantasia. Os homens podiam se submeter às suas doçuras, às suas graças, porém minimamente, já que seus efeitos deveriam ser mediados pela razão. Reduzida ao mínimo e à falta de variedade, sua simplicidade, também característica da natureza, poderia ser controlada pela razão. Para não tornar-se mero adorno dos sentidos e aproximar-se da condição da razão, sua simplicidade e sua monotonia eram condições indispensáveis.

A ornamentação pertencia ao terreno prático, empírico, agradável aos sentidos, por isso ela era rejeitada pela razão no campo 
teórico. Sua proximidade com a razão se dava pela linguagem verbal, símbolo da verdade, e deveria conduzir a música de forma natural. O sentido da música era determinado pelas palavras que, através da razão, fariam reconhecer os modelos retirados e imitados da natureza.

Lecerf tinha na sua concepção de natureza, como acontecia no século XVII e em meados do século XVIII, um sinônimo de razão e verdade. Nesse período, o vocábulo “imitação" nomeava o procedimento usado nas artes para reproduzir traços retirados de modelos da natureza em objetos artísticos não naturais e realçar sua verdade, evidenciá-la. A natureza, princípio de todas as coisas, fornecia todos os traços que seriam reconhecidos nas cópias reproduzidas pelas artes através da imitação, destinada a embelezar e tornar mais agradável a verdade racional através da ilusão promovida pela cópia.

Raguenet e Lecerf foram participantes e testemunhas de uma rivalidade entre França e Itália no início do século XVIII. A discussão fez emergir um problema sociocultural gerador de uma evolução quase dolorosa das mentalidades, porque relacionado à noção de orgulho nacional. Ao estabelecer uma ópera francesa - inspirada no teatro clássico, em suas maquinarias, no balé de corte, no balé comédia e na pastorale, e mesmo na ópera italiana -, Lully e Quinault ofereceram aos franceses aquilo que desejavam: o orgulho de poder desfrutar do reconhecimento, na Europa, de sua música como um gênero que na época era considerado o maior e mais representativo da cultura de uma nação como era a francesa. Na medida de seu desenvolvimento, os criadores de ópera francesa tomaram um partido deliberadamente oposto ao dos italianos, sobretudo no tratamento da língua, ponto estratégico de futuros conflitos, como foram as querelas da segunda metade do século XVIII, e em particular relacionados ao recitativo. Nas óperas, foi adotado o modelo da declamação teatral para o recitativo, tomado como referência à tragédia clássica, como para enobrecer esse gênero, tornando-o sujeito a críticas. Além disso, escrever uma tragédia foi, durante muito tempo, uma passagem obrigatória para os escritores de peças cômicas, ligeiras ou de meia caracterização, para que elas fossem 
reconhecidas como de autores dignos do respeito da comunidade literária, caso contrário, elas não teriam valor algum.

Não só Raguenet e Lecerf se posicionaram a favor das emoções ou da razão nas discussões sobre ópera francesa e italiana, assim como sobre a língua mais apropriada para o canto. Outros autores deixaram reflexões sobre a ópera, como o poeta Antoine-Louis Le Brun (1680-1743), que em seu texto Réponse a une epistre satyrique contre l'opéra [Resposta a uma epístola satírica contra a ópera], de 1712, demonstrou um vínculo bastante estreito com a maneira clássica e racional de fazer ópera, como mostra o fragmento de texto a seguir:

La Machine n'est point interdite sur la Scene de l'Opéra; au contraire elle y produit souvent des beautez. La Fable de l'Opéra, et celle de la Tragédie d'Aristote, sont d'un goût différent, quoy qu'elles ayent quelque chose de commun entr'elles: ainsi il ne faut point les comparer. Les principes sur lesquels vous raisonnez ne sont pas incontestables: vous vous êtes mis dans l'esprit qu'elles devoient se ressembler entierement, et vous vous trompez en cela. L'Opéra est un spectacle nouvellement inventé, qui a en particulier ses loix et ses beautez. Ce qui seroit irrégulier ailleurs par le fond, y devient régulier par la forme. Sangaride est dans Atis ce qu'elle doit être, comme Junie l'est dans Britannicus; et soûtenir le contraire, c'est prétendre qu'une belle brune n'est point agréable, parce qu'elle n'a pas les cheveux blonds. (Le Brun, 1712, p.27)

[A máquina não é proibida na cena da ópera. Ao contrário, com frequência ela produz belezas. A fábula da ópera e a da tragédia de Aristóteles são de gostos diferentes, embora tenham alguma coisa em comum. Assim, não é necessário compará-las. Os princípios sobre os quais raciocinais não são incontestáveis: o senhor colocou em seu espírito que elas devem se assemelhar inteiramente, e se equivocou. A ópera é um espetáculo recentemente inventado, que tem, em particular, as suas leis e as suas belezas. O que seria irregular, alhures, pelo fundo, torna-se regular pela forma. Sangaride é 
em Átis o que ele deve ser, como Juno é em Britannicus, ${ }^{35}$ e dizer o contrário é o mesmo que pretender que uma bela morena não seja agradável porque não possui cabelos louros.] (Tradução nossa)

A ópera deveria se estruturar pela razão, como já exposto, mesmo sendo um gênero relativamente novo, buscando sua regularidade em concordância com a tradição clássica, embora a fábula de uma ópera fosse diferente da fábula de uma tragédia estruturada por Aristóteles em sua Poética. A fábula de uma ópera, embora usasse o respaldo da poética clássica, se constituiu também de acordo com a tragédia clássica francesa do século XVII e mesmo tragédias desse período foram musicadas para a ópera.

A ópera como tragédia era tão mais forte, tão mais familiar, que o autor considerou que sua música devesse ser interditada, restando apenas o aspecto teatral e literário:

Parce qu'on chante à l'Opéra, vous voudriez qu'on chantât par-tout. Ce n'est point une nécessité: l'Opéra n'est fait que pour le plaisir, l'usage y autorise la Musique, et l'interdit où vous voulez l'admettre. Un Prédicateur ne s'en est jamais servi dans ses Sermons, ni un Avocat dans ses Plaidoyers. Les Musiciens ne pourroient y suffire, et ceux qui reciteroient de si longs monologues, s'épuiseroient bientôt. Il est vrai qu'ils pourroient par là réveiller l'attention des auditeurs, ou des Juges: mais l'éloquence n'a pas besoin de ce secours; d'ailleurs la Musique ne se marie pas bien avec la prose. Voila en partie, Monsieur, en quoy cloche vôtre comparaison, puisque vous demandez qu'on vous le fasse voir. (Le Brun, 1712, p.30)

[Porque cantamos na ópera, quereis que cantemos em todos os lugares. Isso não é necessário: a ópera é feita apenas para o prazer, o uso autoriza a música e proíbe onde quereis admitir. Um pregador nunca serviu-se de seus sermões, nem um advogado de suas defe-

35 Átis e Britannicus são peças teatrais dramáticas de autoria de Racine. 
sas. Os músicos não poderiam resistir, e aqueles que recitassem longos monólogos se esgotariam rapidamente. É verdade que eles poderiam despertar a atenção dos ouvintes, ou dos juízes, porém a eloquência não precisa desse apoio. Aliás, a música não se casa bem com a prosa. Eis, em parte, Monsieur, em que se apega sua comparação, pois nos convidastes a observar isso.] (Tradução nossa)

O prazer ${ }^{36}$ da ópera, assim como o do espetáculo teatral, era dirigido primeiramente à razão, depois ao prazer dos sentidos. A imitação da natureza era um preceito unânime para aqueles que consideravam o bom gosto do ponto de vista das regras. O prazer da razão estava em observar os traços brutos da natureza transformados em traços aperfeiçoados e melhorados na ópera. Esse prazer deveria se dirigir à razão, como faziam advogados e pregadores quando se dirigiam a seus espectadores através do discurso, através da linguagem verbal. Mas, no fragmento de texto anterior, percebe-se que não havia um consenso entre música e espetáculo teatral, mas, na verdade, um distanciamento.

Je conclus différemment de vous. Laissons l'Opéra tel qu'il est: plus de régularité le rendroit peut-être moins agréable, et le feroit sortir de son caractere. Il est dans son genre ce qu'il doit être, et ne peut paroître difforme, qu'aux yeux qui veulent qu'on le fasse sur un modele qui n'est pas le sien, et qu'à ceux qui ne le regardent

36 Prazer e dor constituem os tons fundamentais de qualquer tipo ou forma de “emoção". A determinação de suas características depende da função que se atribui às emoções, e por isso está relacionada com a teoria geral das emoções. Aqui é preciso observar que, na tradição filosófica, essa palavra tem um significado diferente do de felicidade, mesmo quando ligada a ela. O prazer é indício de um estado ou condição particular ou temporária de satisfação, enquanto a felicidade é um estado constante e duradouro de satisfação total ou quase total. A mais famosa definição de Prazer foi a de Aristóteles: "Prazer é o ato de um hábito conforme a natureza”, sendo preciso lembrar que hábito significa "disposição constante". Essa definição servia para desvincular o prazer de sua conexão com sensibilidade, visto que um hábito pode ser sensível ou não (cf. Abbagnano, 2007, p.786). 
point dans son veritable point de vûë. Il n'est pas facile d'effacer les impressions qu'un homme comme vous donne au Public. J'espere pourtant le désabuser, et vous aussi: je me flate que dans la suite vous lirez avec plus d'attention et de plaisir, les Pieces dont vous méprisez la Fable, et dont vous craignez la représentation, et que vous réconcilierez l'Opéra avec le bon goût et les bonnes moeurs. Je finis en loüant le zele que vous faites éclater, qui convient à un homme de vôtre profession. Les traits ingénieux et satyriques qui brillent dans vôtre Epître, ne méritent pas moins d'éloge. J'y ai admiré plus d'une fois la grace et l'enjouëment dont vous assaisonnez vos pensées: et aprés avoir pris la liberté d'y répondre, je vous demande celle de me dire. (Le Brun, 1712, p.34)

[Eu penso diferente do senhor. Deixemos a ópera tal qual ela é: a maior regularidade talvez a torne menos agradável e a faça desviar de seu caráter. É no seu gênero que ela deve ser, e só pode parecer disforme aos olhos dos que querem que se realize baseada em um modelo que não é o seu e que não a observam do seu verdadeiro ponto de vista. Não é fácil apagar as impressões que um homem como vós transmite ao público. Espero, portanto, corrigi-lo, e vós também me lisonjeareis se, na sequência, lerdes com mais atenção e prazer as peças nas quais reprovais as fábulas, as quais temeis a representação, e reconciliareis a ópera com o bom gosto e os bons costumes. Finalizo louvando o zelo que fizestes esclarecer, o qual convém a um homem de sua profissão. Os traços engenhosos e satíricos que brilham em vossa carta não merecem menos elogios. Admirei mais de uma vez a graça e a espirituosidade nas quais assentais vossos pensamentos. E, após ter tomado a liberdade de responder, peço-vos que me respondais.] (Tradução nossa)

As impressões, nesse texto, também foram direcionadas à fábula. ${ }^{37}$ Ao abordar os problemas musicais, Le Brun falou, na verdade, de problemas literários, pois observou que algo estava em

37 A fábula é a história, a narrativa propriamente dita, é o mesmo que o mito na tragédia, seu elemento mais importante. 
desequilíbrio em sua própria constituição. Por isso, recomendou ler o texto com mais atenção e prazer, pois as irregulares poderiam não existir de fato. Se o foco estava na história, esta se mostrava mais importante que a música, porque direcionada à razão. A fábula, como representação, ordenava o bom gosto e os bons costumes. Conciliar a ópera com os bons costumes demonstrava que ela tinha o papel de educar a audiência para comportar-se em sociedade. Atentou também para o fato de que a ópera se travestia de um modelo que não era o dela, pois, antes de tudo, era um gênero teatral, e tentar observá-la através desse modelo geraria equívocos. A ópera, na verdade, não satisfazia naturalmente seu intuito, como observaremos mais à frente com Morellet.

Nesses fragmentos do texto de Le Brun, identificamos a ideia de bom gosto vinculada à tradição clássica e proporcional ${ }^{38} \mathrm{em}$ relação à razão. Se o bom gosto devia ser proporcional, era porque a razão era formulada com base em conceitos matemáticos, como se pensava na época. A música, para ele, era algo menor e estava onde "não deveria ser admitida". Reconheceu a ópera como uma novidade, um gênero recente, e procurou nela os traços cênicos e textuais como os mais válidos e dignos de atenção. Afirmou que a fábula da ópera e a da tragédia, segundo Aristóteles, eram diferentes, mas que no espírito deveriam ser a mesma coisa. Era o modelo da tragédia que deveria ser imitado, mesmo na ópera.

38 A proporção, nesse caso, também é pensada segundo a Poética de Aristóteles (1986): “[...] E assim, tal como em relação aos corpos e aos animais, é necessário que tenham uma dimensão que possa ser abrangida por um olhar também em relação aos enredos, será necessária uma duração determinada, fácil de recordar. Os limites da extensão, de acordo com os concursos e a faculdade de percepção, não são do âmbito da arte, pois, se fosse preciso apresentar a concurso cem tragédias, competiriam perante as clepsidras como aconteceu algumas vezes, segundo dizem. Pela própria natureza da ação, em matéria de duração, o limite mais amplo, desde que se seja perfeitamente claro, é sempre o mais belo. Para dar uma definição em termos genéricos, o limite conveniente da extensão é que seja tal que reúna, de acordo com o princípio da verossimilhança e da necessidade, a sequência dos acontecimentos, mudando da infelicidade para a felicidade e vice-versa" (cf. Poética, VII, 1451a 4-15). 
Na relação entre música e poesia, e no que se referia à prosa, Le Brun afirmou que a música e a prosa não casavam muito bem. Mas no último fragmento de texto ele expressou a ideia de que a ópera deveria ser exatamente como era, sem tanta regularidade, pois muito regular ela seria menos agradável. Assim ela deveria ser, assim era a sua natureza. Também aqui percebe-se que, para a concepção da época, a música apresentava problemas de classificação e a linguagem verbal, mesmo transpondo à música um elemento racional, tinha problemas de conciliação com ela. Os elementos dramáticos concernentes à categoria social das personagens e suas características não deveriam ser deformados. Isso foi percebido no texto de Le Brun quando ele disse, por exemplo, que Juno, na obra Britannicus, de Racine, deveria ser como era, e declarou que ser outra coisa não seria condizente, pois fugiria das proporções e dos padrões clássicos estabelecidos.

Depois da segunda metade do século XVIII esse elemento irreconciliável entre texto e música foi definido como natural em música.

O agradável e o prazer das óperas estavam na fábula, na estrutura literária de seu discurso, e não na música. Se a música ganhasse mais evidência, ofuscaria a razão, e por isso deveria ocupar um patamar inferior. Sem o apoio do texto, se direcionaria somente aos sentidos, porém, vinculada ao texto literário, não poderia tornar-se mais evidente e receber mais realce do que ele próprio, sob o risco de agradar mais aos sentidos do que à razão. Como imitação da natureza, a música de ópera, por si mesma, seria incapaz de, sozinha, cumprir as suas regras. Sem a linguagem verbal, ela não tornaria a tradição clássica reconhecível em seu objeto, por esse motivo possuía texto, mesmo que esse molde literário não fosse o dela.

Le Brun e Lecerf concordavam que a autoridade clássica e racional deveria guiar as artes e a música.

Em 1741, Remond de Saint-Mard (1682-1757), escritor francês, autor de dissertações estéticas e literárias sobre ópera, em seu texto Refléxions sur l'opéra [Reflexões sobre ópera], tratou da teoria 
da verossimilhança aplicada à ópera e de sua relação com a tragédia antiga, mas também da comoção e do prazer sentidos pelos ouvintes, concernentes aos efeitos da própria música. Os fragmentos de texto a seguir trazem as impressões desse autor sobre a ópera.

Je sais qu'il y a bien du mal à dire de l'Opera en général, et j'ai commencé par en convenir. Mais quand je vous dirai que la Scene que je viens de citer, [-9-] prise séparément et en elle-même, est une chose admirable, qu'elle a tout ce qu'il faut pour produire en chant un effet merveilleux, je vous défie, vous et qui que ce soit, de me le disputer, et ne dites pas qu'elle seroit plus belle dans une déclamation simple: je dis hardiment que cela n'est pas possible, et je le soutiendrai devant toute la Terre. Qu'on fasse revivre par curiosité la Journet et la le Couvreur: Que l'une fiere de ses talens, déclame cette belle Scene avec toute la finesse, avec toute l'intelligence qu'elle portoit au Théâtre: que l'autre animant ses beaux yeux, déployant ses beaux bras, mette à ses chants et à son action, ce feu, cette dignité, cette noblesse, qui nous fait souvenir d'elle avec tant de plaisir, je suis sûr que nous serons tout autrement émus par les chants de la Journet, que par la déclamation de la le Couvreur, y eût-elle mis cette perfection, qui lui a valu autrefois de votre part tant d'éloges. (Saint-Mard, 1741, p.8)

[Eu sei que existem muitas coisas a dizer sobre a ópera, e comecei por concordar. Mas, quando eu lhe disser que a cena que acabo de mencionar, tomada em separado, em si mesma, é algo admirável, que possui tudo o que é necessário para produzir, em canto, um efeito maravilhoso, eu vos desafio, a vós e a outros quaisquer, a debater, e não afirmeis que ela seria mais bela em uma declamação simples. Digo corajosamente que isso não é possível, e sustentarei diante de toda a Terra. Que façamos reviver a Journet e a Couvreur; que alguém seguro de seus talentos declame esta bela cena com toda a elegância, com toda a inteligência que ela traz ao teatro; que a outra, animando seus belos olhos, estendendo seus belos braços, 
coloque em seus cantos e em suas ações este fogo, esta dignidade, esta nobreza que nos fazem rememorá-la com tanto prazer. Tenho certeza de que seríamos tão emocionados pelos cantos da Journet quanto pela declamação da Couvreur, feita com perfeição, e que lhe valeu uma vez mais, de sua parte, tantos elogios.] (Tradução nossa)

Nesse fragmento, Saint-Mard demonstrou que o equilíbrio da composição da ópera se constituía pela declamação. Esta, com a força dramática do texto literário, orientava o olhar, as inflexões emocionais da palavra, o gesticular dos braços. A ópera ainda era um objeto para os olhos, suas medidas e proporções se davam pelo olhar, a linearidade de seu discurso era moderada pela razão. Ela deveria se constituir como uma representação feita pela pintura, em perfeito equilíbrio. O canto da ópera La Journet era comovente e movia as paixões, os afetos. Era agradável aos sentidos, mas as exigências de cumprimento das regras dramáticas deveriam ser satisfeitas em primeiro lugar.

Il y a dans la Musique une je ne sçais quelle Analogie avec nos passions, une certaine force pour les peindre, à laquelle les paroles toutes seules n'atteindront jamais, et dont les passions, pour être exprimées dans toute leur énergie, auront toujours besoin. Car enfin, si les paroles peignent les troubles, les agitations, les mouvemens et l'ame: elles ne les peignent avec vérité et avec force, qu'autant qu'elles sont aidées des inflections, qui produites par nos mouvemens mêmes, et faites pour les accompagner, servent admirablement à les faire reconnoître; or cette suite d'inflections différentes, ce mélange, cette succession variée de sons, tantôt hauts, tantôt bas, tantôt enflés, tantôt diminués, forment nécessairement un chant; et il est certain que ce chant, qui n'est autre chose que notre Récitatif, bien fait par le Musicien, et bien débité par l'Acteur, loin d'être hors de la Nature, sera dans tous les tems, et dans tous les Pays, l'image la plus naïve de nos mouvemens, et le langage le plus fidéle de la passion. (Saint-Mard, 1741, p.10) 
[Há na música um não sei quê de analogia com nossas paixões, uma certa força para pintá-las, ${ }^{39}$ as quais apenas as palavras jamais conseguirão revelar, e as paixões, para serem expressas com toda a sua energia, sempre precisarão de auxílio. Pois, enfim, se as palavras pintam as angústias, as agitações, os movimentos e a alma, elas não o fazem com verdade e força. Na medida em que são auxiliadas pelas inflexões produzidas pelos nossos movimentos e feitas para acompanhá-las, servem admiravelmente a fazê-las reconhecer. Pois esta sequência de inflexões diferentes, esta mistura, esta sucessão variada de sons, sejam agudos, baixos, aumentados, diminuídos, formam necessariamente um canto, e, certamente, este canto não é outra coisa senão o nosso recitativo, bem feito pelo músico $e$ bem desenvolvido pelo ator. Longe de estar distante da natureza, será, em todos os tempos e em todos os países, a imagem mais primitiva de nossos movimentos e a linguagem a mais fiel da paixão.] (Tradução nossa)

Saint-Mard, nesse último fragmento de texto, esclareceu que as palavras poderiam expressar nossos sentimentos, nossas angústias, mas, para expressá-los verdadeiramente, com toda a sua intensidade, naquilo que eram incapazes apenas textualmente, elas precisariam do auxílio da música, única capaz de promover e fazer reconhecer sua expressão, por acompanhar as inflexões das palavras. A música possuía alguma analogia com as paixões e certo poder para pintá-las. Sem ela, as paixões humanas contidas nas palavras não mobilizariam de maneira adequada as paixões humanas.

39 Pintar, aqui, se refere à capacidade que a música tinha, nessa concepção, de realçar as palavras de tal maneira que seu significado ficasse plenamente evidente e inteligível para o ouvinte. A música, por si mesma, não seria capaz de transmitir a dimensão dos significados de um texto, se quisesse, por exemplo, expressar a angústia sentida por uma personagem diante de alguma fatalidade. O texto, sozinho, embora pudesse expressar as paixões das personagens de uma ópera, não teria o mesmo efeito se viesse acompanhado da música. Por isso dizer-se que a música pintava as paixões humanas, trazendo à tona sua real dimensão. 
As paixões, sempre mediadas pela razão e atingidas por um movimento medido e intencional na composição musical, eram intensificadas pela música. Na verdade, as palavras, sozinhas, não possuíam tanto poder de comoção se estivessem separadas da música. O prazer estético no início da quarta década do século XVIII já havia começado a mudar de perfil. A música poderia atingir os sentimentos, os quais constituíam, nesse momento, critério para julgamento artístico, como fora demonstrado no tratado de Jean-Baptiste Dubos, Reflexões críticas sobre a poesia e a pintura, de 1719, republicado em 1733, a ser tratado no próximo capítulo.

A ópera como espetáculo, regrando-se pela imitação de modelos da natureza, por vezes era considerada incompleta por se valer de um modelo trágico e racional que não era o seu. As exigências relativas à sua racionalidade foram abrandadas, porque as sensações promovidas pela música passaram a ser consideradas capazes de intensificar os significados das palavras e, assim, mover as paixões humanas. Não só a linguagem verbal, mas o canto, em consonância com os movimentos do ator, expressavam a imagem fiel da paixão, numa pintura completa das emoções.

A cela, Monsieur, vous vous imaginez qu'on n'a rien à répondre: permettez-moi de vous dire que vous vous trompez. Je dis moi que quelque fol, et que quelque ridicule que paroisse un pareil dessein, ceux qui l'ont imaginé n'étoient point sots, et qu'en qualité de gens qui nous avoient bien étudiez, ils pouvoient se flatter de l'exécuter. Vous ne nous connoissez pas: on nous croit fort attachés à la vrai-semblance, et nous le sommes en effet, au point que nous crions comme des désesperez quand on y manque, sur-tout quand nous comptons qu'on n'y manquera pas. Mais qu'on nous annonce, qu'on nous avertisse qu'on y manquera, qu'on prenne le plus petit prétexte du monde pour y manquer. Qu'il arrive un Dieu, un Enchanteur, une Fée: Qu'on nous tourne la tête avec un peu de merveilleux, nous dispensons de cette vraisemblance, qui nous est si chere, du moins est-il sûr que nous souffrons peu de ne la pas trouver; pourvû qu'on nous dédommage de son absence. Car 
après tout, nous ne sommes point sots, et si nous renonçons quelquefois à ce que nous aimons, c'est toujours pour avoir quelque chose que nous aimons davantage. (Saint-Mard, 1741, p.12-4)

[A isso, senhor, imaginais que nada temos a responder. Permiti-me dizer que estais enganado. Digo mesmo que por mais louco, por mais ridículo que pareça tal projeto, como aqueles que o imaginaram não são tolos e, na qualidade de pessoas que são, que bem conhecemos, eles poderiam se gabar de executá-lo. Vós não os conheceis. Cremos que estamos muito atrelados à verossimilhança, e o estamos, com efeito, a ponto tal que choramos desesperadamente quando ela falta, sobretudo quando é dito que ela não mais faltará. Mas, quando é dito, quando somos avisados de que a perdemos, quando usamos a menor desculpa do mundo para perdê-la, chega um deus, um feiticeiro, uma fada que faz girar nossas cabeças com algumas maravilhas, dispensamos essa verossimilhança que nos é tão cara, e certamente sofremos menos por não encontrá-la, desde que sejamos compensados pela sua ausência. Afinal de contas, não somos tolos, e se renunciamos algumas vezes àquilo que amamos, é sempre para ter alguma coisa que amamos bem mais.] (Tradução nossa)

Nesse fragmento, Saint-Mard disse ao seu destinatário o quão absurdo e tolo era o fato de algumas pessoas elogiarem apenas a execução, já que eram fortemente dependentes da verossimilhança, e não levá-la em consideração seria de uma perda a lamentar. $\mathrm{O}$ prazer da execução musical colocaria a ilusão em segundo plano, tornando-a até mesmo inútil se o objetivo do espectador fosse apenas a música em si, e não a busca da satisfação da razão. Em determinado momento, a chegada de uma fada traria a felicidade da verossimilhança, mas o foco somente na música mostrava o quanto o desejo de satisfação da teoria da verossimilhança começava a ficar em segundo plano.

Voilà, Monsieur, nos dispositions à tous; dispositions qui font partie de notre essence, et que vous êtes bien le maître de ne pas 
approuver si vous voulez; mais que nous porterons en dépit de vous, non-seulement à l'Opera, mais encore dans les genres qui nous paroissent les plus raisonnables. Voyez ce genre à qui l'on a donné de si beaux et de si superbes noms: celui que par excellence l'on a appellé le chef-d'oeuvre de l'esprit humain, le Poëme Epique. Combien de choses n'y a-t'on pas à digerer: des statuës qui parlent, des trépieds qui marchent, des vaisseaux qui se gouvernent eux-mêmes: Passez de-là à nos deux genres de Poësie, où la vraisemblance est le plus recommandée, et où en effet elle paroît le plus nécessaire, la Comedie et la Tragedie. Combien de fois l'imagination n'y est-elle pas violentée? Que dites-vous des Monologues, les trouvez-vous bien dans la nature? et ces à parte, qui entendus distinctement par le Parterre sont censez ne l'être point de ceux à côté de qui l'on est: tout cela est-il bien dans la vrai-semblance? et ces à parte, qui entendus distinctement par le Parterre sont censez ne l'être point de ceux à côté de qui l'on est: tout cela est-il bien dans la vrai-semblance? Tout cela se souffre néanmoins (...) si toutes ces imperfections étoient ôtées. (Saint-Mard, 1741, p.14-5)

[Eis, senhor, que estamos dispostos a tudo, disposição que faz parte da nossa essência, a qual sois mestre em não aprovar, se quiserdes. Mas, apesar de vós, arcaremos não apenas com a ópera, mas também com gêneros que nos parecem mais razoáveis. Vede esse gênero, para o qual foram dados os mais belos e soberbos nomes, esse que, por excelência, foi chamado de obra-prima do espírito humano, o poema épico. Quantas coisas não foram digeridas: as estátuas que falam, os trépieds ${ }^{40}$ que andam, os barcos que governam a si mesmos. Passemos então aos nossos dois gêneros de poesia nos quais a verossimilhança é a mais recomendável e, com efeito,

40 "1. Antiguidade. Móvel de três pés que serve de mesa ou de suporte. 2. Mobiliário. Pedestal, assento quente de três pés, ao gosto antigo, nos estilos diretório e imperial" (Hautecœur, Art sous Révol. et Emp., 1954, p.114). Disponível em: <http://www.cnrtl.fr/definition/tr\%C3\%A9pieds>. Acesso em: 15 abr. 2014. 
parece ser a mais necessária, a comédia e a tragédia. Quantas vezes a imaginação não foi violentada? O que dizeis sobre os monólogos? Eles se encontram na natureza? E as partes, que, ouvidas em separado da plateia, supostamente estão do lado oposto em que nos encontramos, isso seria aceitável na verossimilhança? Tudo isso parece de menor importância [...] se todas as imperfeições forem eliminadas.] (Tradução nossa)

Mais do que ouvir a ópera, o mais importante era vê-la. A descrição nesse texto é literária, faz referência à tragédia na composição da ópera e a todos os elementos constituintes da tragédia e do poema épico. O desejo da escuta literária, descritiva e representativa, a referência a seres mitológicos e ao aspecto violento da tragédia comoviam seus ouvintes, como acontecia em situações reais. Perante esse espetáculo, era inaceitável reportar tão somente ao aspecto musical, inferior na trama, em que o mito atingia as paixões humanas devido a um efeito de catarse no espectador.

Il en est de même de l'Opera. Il y a mille choses qui y sont mises en Musique, et qui n'y devroient pas être; mais comment faire? Pour avoir ce qu'on aimoit, il a bien fallu se résoudre à avoir ce qu'on n'aimoit pas. Si nos Operas étoient simplement déclamés, tous les défauts dont vous vous plaignez disparoitroient. Ces Récits qui vous y déplaisent, se trouveroient à leur place, et ne vous choqueroient plus. Mais toutes ces belles Scénes, qui vous serrent le coeur, dans Armide et dans Atys: ce bel accompagnement qui les soutient, ces belles Ritournelles qui les annoncent; vous ne les auriez plus, et assurément à tous ces retranchemens vous auriez bien à perdre. Croyez-moi, Monsieur, quand on a fait un Opera pour la premiere fois, on a bien pensé à ce qu'on faisoit: quelqu'un a dit, dès que les Arts, qui sont faits pour peindre, peuvent donner une nouvelle vie, une seconde expression à ce qu'ils auront à représenter, dès qu'ils peuvent se prêter des secours, des agrémens mutuels, quels inconvéniens y auroit-il à les faire marcher et imiter ensemble? En conséquence de cette observation, on a 
associé la Poësie avec la Musique; on a été plus loin, on y a associé la Danse, on a uni ces trois Arts, pour donner aux mouvemens et aux objets qu'on avoit à peindre, plus de force, plus de vérité, et plus d'agrémens. De vous assurer que ce projet-là s'exécute bien régulierement, c'est une autre affaire. Mais prenez garde qu'il suffit, pour qu' on ait pû en hasarder le mélange, que ce mélange ait réussi, et l'expérience nous apprend qu'il a réussi, et que souvent il réussit encore. (Saint-Mard, 1741, p.15-8)

[Isso também ocorre na ópera. Existem mil coisas que são colocadas na música e que não deveriam estar. Mas como fazer? Para ter o que amamos, precisamos escolher ter aquilo que não amamos. Se nossas óperas fossem simplesmente declamadas, todos os defeitos que apontais desapareceriam. Esses recitativos que não vos agradam se encontrariam em seu lugar e não chocariam. Mas todas essas belas cenas, que endurecem o seu coração, na Armide e na Atys, ${ }^{41}$ o belo acompanhamento que as sustenta, os belos ritornellos que as anunciam, vós não os teríeis, e seguramente também não teríeis todos esses empecilhos. Creia-me, senhor, quando fazemos uma ópera pela primeira vez, pensamos muito bem no que fazemos. Alguém disse que, desde que as artes sejam feitas para pintar, elas podem dar uma nova vida, uma segunda expressão àquilo que queremos representar; desde que elas possam se prestar ao apoio, à aprovação mútua. Quais inconvenientes colocariam no desenvolvimento e na imitação em conjunto? Em consequência disso, associamos a poesia com a música e, se formos mais longe, associaremos também à dança, uniremos as três artes para dar aos movimentos e aos objetos que temos para pintar mais força, mais verdade e mais aprovação. Assegurar que esse projeto pode ser bem executado regularmente é outra coisa. Porém, saiba que é suficiente, para que se possa aventurar a fazer essa mistura, que ela seja bem sucedida, e a experiência demonstre que foi bem sucedida, e com frequência seja realizada.] (Tradução nossa)

41 Armide e Artis são óperas de Lully. 
Por esse fragmento, inferimos, das palavras de Saint-Mard, que a música não se conciliava com a palavra e que, se as óperas fossem simplesmente declamadas, nenhuma queixa haveria contra elas e em nada desagradariam. No entanto, o autor revelou que os acompanhamentos eram belos e que valeria a pena ouvi-los. Ele falou da poesia como acontecimento primeiro, a qual posteriormente foi unida à música e depois à dança. A união das três artes - poesia, música e dança - pintou os objetos e lhes deu movimentos de maneira mais prazerosa. As artes prestavam auxílio umas às outras para produzir prazeres mútuos. Esse era o espírito do conhecedor, segundo a concepção da época: saber do que se tratava cada elemento e como eles se conciliavam, trazendo harmonia em conjunto. Mas é nítida a sensação transmitida pelo autor de que palavra e música tinham algo que ficava faltando na imitação. Mais do que assistir à ópera, assistia-se à representação trágica teatral nela contida. A música não realizava totalmente sua função imitativa na ópera, embora impulsionasse as paixões e agradasse aos ouvintes. O equilíbrio entre música e poesia era possível se o texto orientasse a trajetória dos significados e a compreensão da música.

Nesse fragmento de texto de Saint-Mard, a música foi apresentada como uma das três artes, em conjunto com a pintura e a dança. $\mathrm{O}$ autor afirmou que a poesia foi associada à música na representação, pois elas prestavam auxílio uma à outra, trazendo regularidade para o espetáculo operístico, muito embora aconselhasse que a mistura das artes não fosse exagerada, apenas o suficiente para atingir seus intentos.

Nesse sentido, embora o pensamento estético estivesse vinculado à razão e à tradição clássicas, e os aspectos emocionais e agradáveis se fizessem sentir, em alguma medida Saint-Mard concordou com Raguenet quanto ao prazer da música, simplesmente. Concordou também ao dizer que as óperas, quando apenas declamadas, eram perfeitas, desaparecendo, assim, suas falhas. A beleza estava no acompanhamento, deixando-se o recitativo mais intacto em seu aspecto declamatório. Havia, portanto, uma tentativa de equilibrar os sentimentos e as emoções com regras racionais e dramáticas. E 
aqui, ao apontar aspectos da teoria da verossimilhança, ao mencionar os monólogos de um texto recitados por um ator (cantor), a música somente realçaria com maior intensidade a presença de um deus ou feiticeiro para mudar o transcurso do destino de uma personagem. $\mathrm{O}$ aspecto agradável da música foi valorizado, e ela atingia as sensações. Isso provocou, nessa primeira metade do século XVIII, outras discussões, como aquela voltada para a estética dos sentimentos, envolvendo os franceses Charles Batteux e o Abade Dubos, que abordaremos no próximo capítulo.

Nessa primeira discussão sobre a imitação e o gosto no início do século XVIII, emergiu o questionamento quanto a avaliar a música pelas sensações. Ainda no século XVII e mesmo no começo do século XVIII, ela foi tratada pelos teóricos e filósofos como parte integrante de um conjunto maior e, muitas vezes, como uma arte inferior, subordinada à matemática e à poesia, sem existência autônoma e sem especificidades. Com os filósofos iluministas, como será visto adiante, começou-se a tratá-la distintamente, a reconhecer e valorizar o seu aspecto empírico. Esta visão se imporá posteriormente, na metade do século XVIII, deteriorando e transformando a teoria da imitação, tida como requisito para a constituição das óperas. 


\section{2 \\ A IMITAÇÃO DA NATUREZA \\ COMO ESTÉTICA DOS SENTIMENTOS}

\section{Abade Dubos e Charles Batteux: premissas de uma estética do gosto e do sentimento}

O fim do reinado de Luís XIV, no início do século XVIII, representou um momento importante na história da pintura e das artes. O desenvolvimento das artes decorativas ${ }^{1}$ levou a sociedade letrada a redefinir as artes, e a música não poderia ficar distante de suas influências, ainda mais a ópera francesa, assunto bastante discutido, com várias tomadas de partido e vários posicionamentos quanto aos seus significados, aos temas retratados e às regras de composição.

A aceitação de uma obra de arte só seria possível se ela estivesse de acordo com as regras do bom gosto e do bom senso, num fazer poético conforme à razão. Esta, por sua vez, tinha seu modelo calcado na teoria da verossimilhança, estruturada na regra das três unidades: ação, tempo e lugar.

1 O termo "artes decorativas" surgiu durante a Revolução Industrial como forma de marcar um momento a partir do qual as mudanças na tecnologia passaram a afetar o mercado artístico, os artistas e os artesãos. 
A teoria da verossimilhança, no racionalismo francês, se fundamentava no texto do capítulo VIII da Poética de Aristóteles. ${ }^{2}$ Ela era um dos requisitos mais importantes das teorias imitativas. A imitação previa um modelo, a natureza, como princípio criador. As artes deveriam criar como a natureza criava. O racionalismo francês ${ }^{3}$ criticava modelos exagerados do período barroco ${ }^{4}$ em nome de um princípio da clareza racional. Esta clareza tinha a beleza e a verdade como algo único: a valoração da beleza e do bom senso só era possível pelo crivo do bom gosto. A natureza era o modelo, mas a maneira de imitá-la deveria estar baseada nas formas poéticas da Antiguidade Clássica e do classicismo francês do século XVII, as quais, por sua vez, também deveriam ser imitadas. A forma poética considerada mais bem acabada era a da tragédia.

A imitação da natureza era um princípio soberano, ao qual todas as belas-artes deveriam submeter-se. Se não o fizessem, corriam o risco de perder sua valoração. No que concernia à pintura e à poesia,

2 Assim como nas outras artes imitativas a um só objeto corresponde uma só imitação, também o enredo, que é imitação de uma ação, deve sê-lo de uma única ação, que forme um todo, e os acontecimentos devem estruturar-se de tal modo que, ao se deslocar ou suprimir uma parte deles, o todo seja alterado e desordenado. Tudo aquilo cuja presença ou ausência passam despercebidas não é parte de um todo (cf. Aristóteles, 2011, VIII, 1451a).

3 As mudanças sociais, intelectuais e artísticas que ocorreram durante o século XVIII alteraram o objetivo e o contexto das teorias musicais. O fortalecimento gradual das interpretações verbais, no século XVII e no início do XVIII, não só enfraqueceu a associação entre a música e a matemática, mas também acelerou a sua integração ao moderno sistema das artes. Uma das consequências disso, para a música, foi o ressurgimento da imitação como conceito teórico central. A música teve de deduzir suas leis a partir dos sentidos e do gosto, e o gosto não se conformou a ela, ao contrário, a música é que se conformou ao gosto (Neubauer, 1992, p.96.)

4 Segundo Gerd A. Bornheim (1975): "Lembremos que a arte barroca preenchia duas finalidades básicas: a glória de Deus e a glória do Príncipe, da Igreja e do Estado. E esta dupla exigência era realizada com temas cristãos e motivos romanos antigos, nas igrejas, palácios, óperas e festas de corte. Mas, com a crise da ideia do Estado e a consciência crescente da impossibilidade de unificação das religiões, esse mundo termina caindo por terra, dando assim lugar à cultura burguesa" (p.14-5). 
a imitação era compreendida de maneira mais clara. Já na música esse princípio não parecia muito claro e bem definido. As explicações para a música eram tomadas das regras para a poesia, o teatro, a dança e a pintura. Até mesmo exigia-se dela que tivesse o comportamento e a representação como de uma pintura, que possuísse um significado e uma representação, como acontecia com a pintura e a poesia. Também se questionava se existiria na música e na música de ópera, em si mesmas, algum significado. Como objeto individual, sem o apoio das palavras, a música seria incapaz de imitar segundo a concepção da época ou, no mínimo, teria seu propósito incompleto e não concretizado, já que precisaria da linguagem verbal para se completar.

O que predominou, e que se tornou mais claro a partir da segunda metade do século XVIII, era a visão de que o papel da música dentro da ópera restringia-se a adornar e realçar os conceitos atrelados às palavras, a fim de agradar à razão, embora a música instrumental, considerada destituída de significado, abrangesse mais domínios no campo operístico e mesmo fora dele. Mas era unânime o pensamento de que essa música não possuía um poder mimético completo.

Em meio à redefinição das artes, destacaram-se o Abade Jean-Baptiste Dubos (1670-1742), teólogo que se dedicou ao direito público e à política, e o Abade Charles Batteux (1713-1780)5 , pro-

5 Batteux, embora inserido dentro de uma estética do sentimento, segundo Ernest Cassirer (1994, p.373) havia explicitado, em termos claros e precisos, que a natureza e suas manifestações seriam determinadas pela razão. A natureza seria submetida a leis universais e invioláveis, às quais também eram submetidas as artes. Falar de uma estética dos sentimentos era dizer que eles eram medidos e mediados pela razão, controlados na sua proporção e na sua intensidade passional. O professor doutor Marco Aurélio Werle, na introdução de sua tradução do tratado de Batteux (2009, p.10), afirma que ele pode ser considerado um percussor de novas formas de pensar a arte, que gradativamente vão deslocando o foco de atenção de uma objetividade racional para uma subjetividade intimista. Em seu tratado, segundo Werle, já se insinua a passagem entre uma poética que estabelece apenas regras objetivas de produção artística para o domínio de uma filosofia da poesia e da arte que 
fessor de retórica e de poesia grega e latina no Collège Royal de Paris. A posição metodológica desses autores quanto às formulações de poética se mantivera na esteira da tradição inaugurada pela Poética de Aristóteles, como modelo e padrão a ser seguido, desde a Antiguidade até meados do século XVIII. "Os dois confirmaram lugares comuns na imitação musical que se originou na música monódica, na qual a melodia e a voz eram superiores à harmonia e aos instrumentos" (Neubauer, 1992, p.102, tradução nossa).

\section{Dubos}

O Abade Dubos envolveu-se em um movimento reflexivo sobre as artes que não cessaria de formular uma teoria da arte. Uma nova percepção dos seus efeitos, estabelecida pela experiência estética do espectador, trouxe uma nova definição de gosto. Nessa mudança de perfil, as experiências do espectador foram definidas em sua obra Réflexions critiques sur la poésie et sur la peinture [Reflexões críticas sobre a poesia e a pintura]. Ele era um amador que ouvia e observava as manifestações artísticas e, do ponto de vista daquele que recebia a obra de arte, ou seja, do receptor, desenvolveu suas reflexões. Construiu, então, um espaço teórico autônomo em relação à recepção da arte, sendo notório o seu interesse pelo espectador.

Dubos utilizou a noção de "sentimento" como julgamento natural para explicar a apreensão das belezas de uma obra de arte. Essa percepção do sentimento por ele analisada trouxe à tona a ideia de que a obra produziria no espectador efeitos ou sensações que modificariam subjetivamente a alma. Em meio ao racionalismo imperante, instaurado desde o século XVII, a ideia de sentimento como julgamento para a recepção da obra de arte era algo novo. Dubos se livrou da racionalização do sensível, conduzindo e reconhecendo

não se contentará apenas com a fixação dessas regras, mas questionará seu princípio especulativo e interno. A concepção de Batteux, como a de Dubos, é racionalista, mas sua estética voltada para os sentimentos é submetida aos preceitos dessa concepção racional advinda de Descartes. 
um estatuto positivo do sentimento, como se este fosse uma espécie de "sexto sentido" enraizado na experiência do receptor.

A esfera do sentimento foi colocada por ele em conjunto com as origens da música, com relação à declamação dos antigos e aos modelos da Antiguidade Clássica que serviram à imitação para as obras de arte:

Les signes naturels des passions que la musique rassemble, et qu'elle emploïe avec art pour augmenter l'énergie des paroles qu'elle met en chant, doivent donc les rendre plus capables de nous toucher, parce que ces signes naturels ont une force merveilleuse pour nous émouvoir. Ils la tiennent de la nature même. nihil est enim tam... etc., dit un des judicieux observateurs des affections des hommes. C'est ainsi que le plaisir de l'oreille devient le plaisir du coeur. De-là sont nées les chansons; et l'observation qu'on aura faite, que les paroles de ces chansons avoient bien une autre énergie lorsqu'on les entendoit chanter, que lorsqu'on les entendoit déclamer, a donné lieu à mettre des récits en musique dans les spectacles, et l'on en est venu successivement à chanter une piece dramatique en entier. Voilà nos opera. (Dubos, 1993, I, \$45, p.151)

[Os sinais naturais das paixões, que a música reúne e emprega com arte para expandir a energia das palavras que coloca em canto, devem, portanto, torná-las mais capazes de nos tocar, porque os signos naturais possuem uma grande força para nos emocionar, a qual retiram da própria natureza. Na verdade, nada há de mais comum em nosso espírito do que os ritmos e os sons que nos excitam, nos inflamam, nos acalmam, nos adormecem, ${ }^{6}$ diz um dos atentos observadores dos sentimentos dos homens. É assim que o prazer do ouvido torna-se um prazer do coração. Daí nascem as canções, e a observação que tínhamos feito de que as palavras dessas canções tinham outra energia quando as escutávamos cantar, quando as escutávamos declamar, dando lugar aos recitativos em música, nos espetáculos, e sucessivamente a uma peça dramática inteira cantada.] (Tradução nossa)

6 Cícero, O Orador, Livro III. 
Sua obra Réflexions, publicada em janeiro de 1719, foi aceita unanimemente e com muito sucesso pelos homens de letras e acadêmicos da época. Nela, discutiu questões atinentes à poesia e à pintura. Com relação à música, discutiu também a ópera. Dubos era um "homem do mundo", inserido na corrente de todas as polêmicas da época, e conhecia as críticas de seu tempo. Era um viajante e colecionava, em suas descrições, quadros que envolviam uma verdadeira experiência estética. Fubini (2007) considerava a obra de Dubos, no que concernia à música, "um dos primeiros intentos conscientes de se conferir à música dignidade de arte" (p.183, tradução nossa).

Dado o sucesso da sua obra, ela foi ampliada e reeditada, e recebeu o acréscimo de um terceiro volume em 1733. Além de reagrupar a obra, Dubos desenvolveu digressões concernentes à música $e$ à declamação dos antigos.

O abade adotou um hábito comum no século XVIII: escrever tabelas analíticas dos temas discutidos em sua obra, para orientar e tornar proveitosa a consulta do leitor. O que ele pretendia com isso era que o leitor, como amador, pudesse expressar o seu gosto sobre ópera, música, teatro, e não somente sobre pintura. Era uma maneira de ajudá-lo a compreender as artes individualmente, embora os temas tratados em todas elas fossem sempre os mesmos.

O modo como Dubos expôs seu trabalho assemelhava-se à visão de um espectador perante as artes, e não à do especialista. Isso revelou não só que eram promovidas com frequência exposições e apresentações nas salas de concerto na época, mas também a existência de um público menos especializado, o qual ele tentou munir de informação através da sua obra.

A pintura histórica, ${ }^{7}$ como gênero, foi escolhida para análise devido ao seu paralelo com a poesia dramática e porque era mais difícil identificar seus temas apenas por meio da observação, o que

7 A pintura histórica se aplica à representação de fatos históricos, de cenas mitológicas e literárias, de cenas da história política. Personagens célebres envolvidas em batalhas, guerras, fatos notáveis eram todos representados em pinturas de grandes dimensões. 
somente os mais experimentados e cultos conseguiam fazer. Tanto uma como a outra permitiam a pintura das paixões e a visão dramática das ações humanas. $\mathrm{O}$ uso da poesia dramática veio na esteira da Poética de Aristóteles. A pintura, para Dubos, estava em primeiro lugar, pois representava a captação do trágico e de seus efeitos passionais num único instante. Já para o teatro eram necessárias a sucessão e a linearidade dos acontecimentos para ter acesso ao todo. Com isso, ele queria demonstrar que os efeitos da pintura histórica eram idênticos àqueles provocados por uma peça de teatro. A pintura era como uma cena teatral, mas pictural. Como a ópera também era vista como um teatro, ela deveria provocar os mesmos efeitos da pintura e do teatro.

$\mathrm{O}$ abade analisou os efeitos do prazer no espectador diante de um espetáculo, tanto teatral como de ópera, o prazer sensível diante de um quadro e de versos. Chamou a experiência e o bom senso do leitor para julgar a obra de arte, considerando não apenas a tradição e seus temas, mas os objetos imitados de modelos retirados da natureza. O receptor da obra de arte deveria também refinar o seu conhecimento sobre as paixões que essas obras suscitavam. Sem esse conhecimento, a função delas seria ineficaz. De alguma maneira, em sua obra ele deu orientações sobre como se comportar perante as obras de arte e a música e mencionou quais seriam os seus efeitos diante do reconhecimento das paixões humanas:

Il suffit de bien connoître les passions violentes pour desirer sérieusement de n'y jamais être assujeti, et pour prendre des résolutions qui les empêchent du moins de nous subjuguer si facilement. Un homme qui sçait quelles inquiétudes la passion de l'amour est capable de causer: un homme qui sçait à quelles extravagances elle conduit les plus sages, et dans quels périls elle précipite les plus circonspects, desirera très-serieusement de n'être jamais livré à cette yvresse. Or les poësies dramatiques, en mettant sous nos yeux les égaremens où les passions nous conduisent, nous en font connoître les symptômes et la nature plus sensiblement qu'un livre ne sçauroit le faire. Voilà pourquoi l'on a dit dans tous les temps que 
la tragedie purgeoit les passions. Les autres poèmes peuvent bien faire quelque effet approchant de celui de la tragédie, mais comme l'impression qu'ils font sur nous n'est point à beaucoup près aussi grande que l'impression que la tragédie fait à l'aide du théâtre, ils ne sont pas aussi efficaces que la tragédie pour purger les passions. (Dubos, 1993, I, §44, p.147)

[É suficiente conhecer as paixões violentas para desejar seriamente jamais sujeitar-se a elas e tomar uma resolução que ao menos as impeça de subjugar-nos facilmente. Um homem que sabe quais inquietudes a paixão do amor é capaz de causar, um homem que sabe a quais extravagâncias ela conduz os mais sábios e em quais perigos precipita os mais circunspectos, desejará seriamente nunca estar à mercê dessa embriaguez. Pois as poesias dramáticas, colocando sob nossos olhos os equívocos a que as paixões nos conduzem, nos fazem conhecer os sintomas e a natureza mais sensível, o que os livros não conseguiriam fazer. Eis o motivo por que dizem, em todos os tempos, que a tragédia purga as paixões. Os outros poemas podem bem produzir qualquer efeito que se aproxime daquele da tragédia, mas, como a impressão que produzem sobre nós não é tão forte como a impressão que a tragédia provoca, com o auxílio do teatro, eles não são tão eficazes quanto a tragédia para purgar as paixões.] (Tradução nossa)

A teoria da arte desenvolvida por Dubos foi a teoria da imitação. A arte foi questionada do ponto de vista das relações entre a cópia e o original, de um lado, e entre a produção e o prazer estético, de outro. Nessa perspectiva, o original reproduzido pela pintura deveria interessar ao espectador. O prazer gerado pelas artes derivava da maneira como elas imitavam objetos capazes de suscitar paixões, embora, em essência, a sua produção fosse fictícia e artificial.

Sobre a imitação, Dubos (1993) escreveu:

Or en distinguant l'attention qu'on donne à l'art d'avec celle qu'on donne à l'objet imité, on trouvera toujours que j'ai raison 
d'avancer que l'imitation ne fait jamais sur nous plus d'impression que l'objet imité en pourroit faire. Cela est vrai même en parlant des tableaux, qui sont précieux par le merite seul de l'execution. (Dubos, 1993, I, §10, p.24)

[Pois, distinguindo a atenção que damos à arte daquela que damos ao objeto imitado, verificamos sempre que - e tenho razão de avançar - a imitação jamais produz sobre nós a mesma impressão que poderia produzir o objeto imitado. Isso é verdade, mesmo no caso de pinturas que são preciosas apenas pelo mérito da execução.] (Tradução nossa)

Quanto às origens, na relação entre música e paixões humanas, o abade afirmou que a música, para agradar mais em seu processo de imitação, procurou tornar os sons naturais retirados da natureza mais aptos para ela, através da harmonia e do ritmo:

La musique, afin de rendre l'imitation qu'elle fait des sons naturels plus capable de plaire et de toucher, l'a réduite dans ce chant continu qu'on appelle le sujet. Cet art a trouvé encore deux moïens de rendre ce chant plus capable de nous plaire et de nous émouvoir. L'un est l'harmonie, et l'autre est le rithme.

Les accords dans lesquels l'harmonie consiste, ont un grand charme pour l'oreille, et le concours des differentes parties d' une composition musicale qui font ces accords, contribuë encore à l'expression du bruit que le musicien prétend imiter. La basse continuë et les autres parties aident beaucoup le chant à exprimer plus parfaitement le sujet de l'imitation. (Dubos, 1993, I, §45, p.150)

[A música, a fim de tornar a imitação que faz dos sons naturais mais capaz de agradar e comover, reduziu-a a esse canto contínuo que chamamos de sujeito. Essa arte encontrou dois meios para tornar o canto mais capaz de nos agradar e emocionar: um é a harmonia e outro é o ritmo. 
Os acordes que constituem a harmonia possuem um grande encantamento para o ouvido, e o apoio das diferentes partes de uma composição musical que produzem esses acordes contribui mais ainda para a expressão do ruído que o músico pretende imitar. $\mathrm{O}$ baixo contínuo e as outras partes ajudam muito o canto a exprimir com mais perfeição o sujeito da imitação.] (Tradução nossa)

A música, então, fazia sua imitação através dos elementos harmônicos e rítmicos. Porém, Dubos não deixava de notar que ela fazia isso da mesma maneira como a pintura se valia do claro/escuro e do traço. $\mathrm{O}$ aspecto observado aí era que o discurso estava presente na música, ou seja, a palavra era usada para que a música assumisse significado:

La musique fait donc ses imitations par le secours du chant, de l'harmonie, et du rithme. Dans le chant il faut noter principalement trois aspects: l'harmonie concerne le son, le discours, la comprehension des mots et la variété de l'expression; le rythme le mouviment harmonieux et la mélodie. C'est ainsi que la peinture fait ses imitations par le secours du trait, du clair-obscur et des couleurs locales. (Dubos, 1993, I, §45, p.151)

[A música, portanto, faz suas imitações com a ajuda do canto, da harmonia e do ritmo. No canto, devem-se notar principalmente três aspectos: a harmonia concerne ao som, o discurso, à compreensão das palavras e à variedade da expressão, o ritmo, ao movimento harmonioso e à melodia. ${ }^{8}$ É assim que a pintura faz suas imitações: com o apoio do traço, do claro-escuro e das cores locais.] (Tradução nossa)

As paixões despertadas pela imitação dos objetos cujos modelos encontravam-se na natureza teriam efeitos menos intensos do que aqueles que os objetos em si produziriam, e era este o prazer gerado

8 Citação de Dubos, mas de autor não identificado. (N. do T.). 
pela imitação: por se apegar ao verossímil, e não ao real, provocava paixões transitórias, sem violência ou resultados nefastos, pois não eram a realidade, apenas assemelhavam-se a ela. Porém, a imitação da bela natureza não deveria acontecer indiscriminadamente, pois as paixões deveriam ter o poder de comover o espectador:

Les hommes avec qui nous vivons, nous laissent presque toûjours à deviner le véritable motif de leurs actions, et quel est le fond de leur cœur. Ce qui s'en échappe au dehors, et ce qui ne paroît qu'une étincelle, vient souvent d' un incendie qui fait des ravages affreux dans l'intérieur. Il arrive donc souvent que nous nous trompions nous-mêmes, en voulant deviner ce que pensent les hommes, et plus souvent encore ils nous trompent eux-mêmes dans ce qu'ils nous disent de la situation de leur cœur et de leur esprit. Les personnages de tragedies quittent le masque devant nous. Ils prennent tous les spectateurs pour confidens de leurs véritables projets et de leurs sentimens les plus cachez. Ils ne laissent rien à deviner aux spectateurs que ce qui peut être deviné sûrement et facilement. On peut dire la même chose des comedies. (Dubos, 1993, I, §44, p.147)

[Os homens com os quais convivemos quase sempre nos deixam adivinhar o verdadeiro motivo de suas ações, o que têm no fundo de seu coração. O que nos escapa, e que só aparece como uma faísca, com frequência origina-se de um incêndio que devasta terrivelmente o interior. Parece, portanto, que com frequência nos confundimos querendo adivinhar o que pensam os homens, e, com mais frequência ainda, eles nos enganam ao se enganarem quando falam de seu coração e de seu espírito. As personagens da tragédia tiram a máscara diante de nós. Elas tomam todos os espectadores como confidentes de seus verdadeiros projetos e de seus sentimentos mais ocultos. Elas não deixam nada para os espectadores adivinharem, a não ser aquilo que com facilidade e segurança pode ser adivinhado. Podemos dizer o mesmo sobre as comédias.] (Tradução nossa) 
Com relação à poesia, pensava-se que ela era explicativa e circunstancial, por isso racional, beneficiando nossos espíritos com a duração de suas diversas ações. Ela pintava as paixões humanas e nos presenteava com personagens variadas e múltiplas. Tinha o poder de metamorfosear-se e estender-se na linha do tempo, além de gerar uma representação na mente do espectador. Já a pintura, segundo Dubos, previa um único espaço e mostrava-nos um único momento do tempo. Ele desenvolveu uma ideia essencial, que era a da comunhão necessária entre a cultura e seu público. Para o abade, um poeta era perfeitamente capaz de tornar seus leitores sensíveis aos infortúnios de um príncipe, mas um pintor já não tinha essa liberdade. A pintura poderia se fazer conhecer, mas não reconhecer, o que era prerrogativa da imitação, ou seja, o reconhecimento através da cópia.

Nesse sentido, a música perseguiria o mesmo objetivo das outras artes, que era dar-se em afinidades através da sua associação com os sentimentos, e assim, com esse poder de despertar paixões, tinha posição mais privilegiada em relação à pintura e à poesia. Esta, para se expressar, usava das palavras instituídas pelos homens, enquanto a música, mesmo sem as palavras, poderia suscitar paixões humanas, mesmo com a certeza de que, sem elas, nada significava. Mas, junto com a poesia, tornava-se mais potente, mais intensa.

Mais do que a comoção poduzida pelo objeto imitado era o modo como se imitava. Isto provocava mais comoção do que a própria cópia do objeto:

[...] assim, para Dubos, a maravilha, o estupor, a ilusão e a verdade não são os únicos ingredientes da emoção estética, pois é bem certo que, para poetas e pintores, os temas são inesgotáveis, e um mesmo tema pode dar vida a mil quadros distintos. $\mathrm{O}$ estilo - na opinião de Dubos - é o recurso mais característico da obra de arte, ainda que não deva ser conceituado unicamente do ponto de vista formal, mas também como uma forma peculiar do gênio do artista em dar-lhe dignidade ao apresentar qualquer tema. (Fubini, 2007, p.184, tradução nossa) 
Dubos tinha consciência da ignorância de um tipo de público diante de um quadro, do teatro e da ópera, por isso publicou seu trabalho. No século XVIII, o público que conseguia reconhecer os significados desse tipo de obra, produzida de acordo com as teorias imitativas, era bastante restrito. Essa questão do reconhecimento, na pintura, daquilo que era expresso pela poesia dramática colocou em evidência não só um problema de gosto, o qual, para a pintura, o teatro e a ópera, se revelou num momento decisivo da história: o fato de que a tradição estava sendo ignorada pelo público emergente.

Com efeito, havia a necessidade de repetir, de cultivar, de elevar os temas, de respeitar a tradição, pois havia o risco de tudo cair no esquecimento, por causa do surgimento de outros interesses. Por conta da influência dos italianos, segundo Dubos, ocorreu a multiplicação de um público não alfabetizado, não letrado, em ascensão econômica, que passou a compartilhar os espaços antes destinados somente a um público seleto e culto. Daí ser essa uma das preocupações da publicação da obra do abade.

Essa necessidade de informar, de expressar o que possivelmente estava sendo esquecido, devido à ascensão de um novo público, menos letrado, pode ser mais bem compreendida através deste texto, em que ele fala da finalidade da tragédia:

Le but de la tragedie étant d'exciter principalement en nous la terreur et la compassion, il faut que le poëte tragique nous fasse voir en premier lieu des personnages aimables et estimables, et qu'il nous les répresente ensuite en un état veritablement malheureux. Commencez par faire estimer aux hommes ceux que vous voulez leur faire plaindre. Il est donc necessaire que les personnages de la tragedie ne meritent point d' être malheureux, ou du moins d'être aussi malheureux qu'ils le sont. Si leurs malheurs ne sont pas une pure infortune, mais une punition de leurs fautes, ils en doivent être une punition excessive. Du moins si ces fautes sont de veritables crimes, il ne faut pas que ces crimes aïent été commis volontairement. Oedipe ne seroit plus un principal personnage de 
tragedie, s'il avoit sçu dans le tems de son combat, qu'il tiroit l'épée contre son propre pere. Le malheur des scelerats sont peu propres à nous toucher; ils sont un juste supplice dont l'imitation ne sçauroit exciter en nous ni terreur, ni compassion veritable. (Dubos, 1993, I, §14, p.38)

[Sendo a finalidade da tragédia provocar em nós principalmente o terror e a compaixão, é necessário que o poeta trágico nos faça ver as personagens, em primeiro lugar, como amáveis, adoráveis, e, em seguida, que as apresente em um estado verdadeiramente deplorável (infeliz). Comece por fazer serem estimados os homens que suscitam a compaixão. É portanto necessário que na tragédia as personagens não mereçam ser infelizes, ou ao menos não sejam tão infelizes quanto são. Se as infelicidades não são apenas puro infortúnio, mas uma punição de suas faltas, devem ser uma punição severa. A menos que essas faltas sejam crimes, não é necessário que eles tenham ocorrido voluntariamente. Édipo não seria a principal personagem da tragédia se tivesse sabido, no tempo de seu combate, que tiraria a espada contra seu próprio pai. A ruína dos celerados não consegue nos tocar. Ela é um justo suplício, cuja imitação não provocaria em nós nem o terror, nem a verdadeira compaixão.] (Tradução nossa)

Outro elemento importante relativo ao esquecimento da tradição era que ela tinha também a função de moralizar a sociedade, já que os espetáculos de ópera possuíam a finalidade de mostrar a verdade da moral. As artes deveriam se acomodar aos costumes vigentes. Elas poderiam ser ilusórias, mas a verdade, com vistas a perpetuar os bons costumes, deveria ser real:

Qu'on ne me fasse point dire après cela, que les poëmes dramatiques sont un remede souverain et universel en morale. Je suis trop éloigné de rien penser d'approchant, et je veux dire seulement que les poëmes dramatiques corrigent quelquefois les hommes, et que souvent ils leur donnent l'envie d'être meilleurs. 
[...] Il est des hommes trop fougueux pour être retenus par des exemples, et des passions trop allumées pour être éteintes par des refléxions philosophiques. La tragédie purge donc les passions à peu près comme les remedes guérissent, et comme les armes défensives garantissent des coups des armes offensives. La chose n'arrive pas toûjours, mais elle arrive quelquefois. (Dubos, 1993, I, §44, p.147)

[Que não me façam dizer, depois de tudo, que os poemas dramáticos são um remédio soberano e universal no que diz respeito à moral. Para mim está muito distante pensar em uma aproximação. Quero dizer apenas que os poemas dramáticos algumas vezes corrigem os homens e que sempre fazem que aspirem a ser melhores.

[...] Existem homens muito impetuosos para serem retidos pelos exemplos, e paixões muito vívidas para serem controladas pelas reflexões filosóficas. A tragédia, portanto, purga um pouco as paixões, como os remédios curativos, assim como as armas defensivas garantem o golpe das armas ofensivas. As coisas nem sempre acontecem assim, mas algumas vezes acontecem.] (Tradução nossa)

Nessa perspectiva estética, diante do fato de que os temas tradicionais começavam a ser ignorados, a música tornou-se foco de reflexões significativas sobre um difícil equilíbrio, já que ela mesma apresentava problemas de classificação e nomenclatura, necessitando da linguagem verbal para ter significados, ligados a uma cultura e tradição clássicas. Sobre a música, Dubos (1993) disse que ela tinha seus significados atribuídos pela instituição da linguagem dos homens:

Il nous reste à parler de la musique comme du troisiéme des moïes que les hommes ont inventez pour donner une nouvelle force à la poësie et pour la mettre en état de faire sur nous une plus grande impression. Ainsi que le peintre imite les traits et les couleurs de la nature, de même le musicien imite les tons, les accens, les soupirs, les infléxions de voix, enfin tous ces sons, à l'aide desquels la nature même exprime ses sentimens et ses passions. Tous ces sons, comme 
nous l'avons déja exposé, ont une force merveilleuse pour nous émouvoir, parce qu'ils sont les signes des passions, instituez par la nature dont ils ont reçû leur énergie, au lieu que les mots articulez ne sont que des signes arbitraires des passions. Les mots articulez ne tirent leur signification et leur valeur que de l'institution des hommes qui n' ont pû leur donner cours que dans un certain pays. (Dubos, 1993, I, §45, p.150)

[Resta-nos falar da música como o terceiro meio que os homens econtraram para dar uma nova força à poesia e colocá-la em um estado que nos causa forte impressão. Assim como o pintor imita os traços e as cores da natureza, o músico imita os tons, os acentos, os suspiros, as inflexões da voz, enfim, todos os sons, com a ajuda dos quais a própria natureza exprime seus sentimentos e suas paixões. Todos esses sons, como já expusemos, possuem uma maravilhosa força que nos emociona, porque eles são os signos das paixões instituídos pela natureza, da qual receberam a energia, em vez das palavras articuladas, que são apenas signos arbitrários das paixões. As palavras articuladas somente ajustam seu significado e o valor da instituição dos homens que lhe deram legalidade em certas regiões.] (Tradução nossa)

Ainda, no que concerne à pintura histórica, a noção de cultura desenvolvida por Dubos se fundamentava nas diferentes culturas nacionais. Ele esboçou, através de um estudo da variedade dos temas nacionais, uma história das variações do gosto. Passou em revista os heróis preferidos dos italianos, dos franceses, dos espanhóis, além de explanar longamente sobre os temas mais apropriados à tragédia e à comédia. Na época em que escreveu suas Reflexões, a expressão das paixões estava sempre no cerne dos debates teóricos sobre a pintura e a literatura, ainda que a imitação das ações humanas constituísse a essência da invenção poética.

Mas, no teatro e na ópera, a pintura das paixões e o valor atribuído à cena representada dependiam do seu poder de suscitar emoções no espectador através da ilusão, ou seja, dependiam do grau 
de verossimilhança da imitação e da expressão das paixões. Era pela verossimilhança que as paixões eram movidas, através da máxima eficácia de trazer ao coração a semelhança do objeto imitado com seu modelo retirado da natureza. Nisso estava o prazer, na ilusão provocada pela semelhança.

Se uma ópera nos move, ela nos seduz, e a força da sedução era devida à capacidade de invenção do artista, com todas as referências e todos os reconhecimentos que o imitado demonstrava ter de seu modelo. A ópera, ao incorporar o teatro, demonstrava o gosto, além de educar e moralizar. Nela, como no teatro, cada povo, segundo Dubos, poderia demonstrar seus caracteres pela declamação, assim como uma ideia relativa de historicidade, já que os franceses se sentiam herdeiros da Antiguidade Clássica e se orgulhavam de seu teatro clássico do século XVII, tornando esses caracteres uma disposição do próprio caráter nacional francês.

O abade julgava que o progresso só seria possível reunindo o máximo de conhecimento possível de épocas passadas, como ocorria com as ciências. Chegou a afirmar que Newton não teria sido quem foi se Galileu não tivesse chegado antes. Para ele, sempre se deviam observar os antigos. Por valorizar a tradição, Dubos acreditava na supremacia dos antigos sobre os modernos, como ocorreu nas querelas sobre essas questões. Ter o máximo de conhecimento das épocas passadas denotava uma preocupação para que a tradição não fosse esquecida.

No entanto, para o abade, era visível que as atividades artísticas se comportavam de modo contrário à estética dos clássicos. E isso era um problema para ele, pois a natureza variava de acordo com o clima de cada região, e o artista copiava a natureza que observava. Jamais a arte fora definida como uma atividade criadora na qual o sujeito criador se destacava de seu objeto. A criação consistia em fazer reconhecer, em objetos não naturais, os traços da natureza. $\mathrm{O}$ abade jamais redefiniu o belo, apenas tornou a estética aberta à graça e à variedade.

A novidade, em Dubos, estava em tentar manter o equilíbrio entre a teoria da arte herdada dos antigos e um ponto de vista mo- 
derno que conduzisse ao estudo das especificidades das artes. Esboçou o que posteriormente seria chamado de teoria da recepção. Não deixou de lado a questão da imitação, pelo contrário, manteve-a em suas reflexões, mas foi notória e evidente a dúvida sobre o objeto representado, o modelo da natureza. Também foi questionado se realmente a imitação como regra ainda era uma norma a ser seguida nas representações artísticas.

O que era moderno era a aceitação do nível interno do receptor do princípio da imitação pelo julgamento a partir dos sentimentos, apesar da estreita relação com as paixões humanas como campo específico da imitação. Daí a ideia de que o músico deveria imitar os tons, os acentos, os suspiros e as inflexões da voz, ou seja, todos os sons que a própria natureza expressava em sentimentos e paixões.

De alguma forma, o estatuto que fora reconhecido ao artista era o mesmo que fora reconhecido posteriormente à obra de arte. Dubos apresentava a obra de arte num interior complexo que levava em consideração os múltiplos olhares que despertava. Numa visão moderna, o leitor, perante a obra de arte, não mais procurava reconhecer os modelos retirados da natureza, dos quais ela havia se tornado cópia perfeita, mas, como estudioso da cultura, abraçara as artes por si mesmas, e as ciências para a sua leitura.

O sentimento promulgado como julgamento estético foi posteriormente imposto na crítica de arte. A maneira de criticar até então limitava-se a verificar se as regras imitativas haviam sido cumpridas, o que foi sendo abandonado, dando lugar a um novo discurso sensível à modernidade e à crítica pela arte em si, e não mais pelas regras do que ela deveria cumprir e representar.

Mas, na época de Dubos, ele havia se distanciado de seus contemporâneos quando estes afirmaram que a música não era mais do que um adorno para o texto poético na representação de uma ópera. Para eles, a música nada mais tinha do que o poder de tornar mais agradável e compreensível o discurso poético, ou seja, pensava-se que ela não tinha significado por si mesma. $\mathrm{O}$ abade não foi contra o conceito de verossimilhança, nem contra o de verdade. A verdade, para ele, era a verdade dos sentimentos, e nisso a música era o 
símbolo de sua expressão. Os sentimentos expressos pelas paixões encontravam-se na natureza. Imitados, eram as verdades que a música realçaria, e nesse aspecto a linguagem verbal da ópera, por si só, não seria capaz de comover.

Nos dizeres do professor de Literatura Comparada da Universidade de Amsterdam, John Neubauer (1992, p.98), os acentos, os suspiros, os tons e sons circunstanciais da voz só poderiam ser evidentes através da música. Sem ela, não cumpririam a função de arrebatar os sentimentos. Sem ela, a verdade dos sentimentos contida nas palavras não seria reconhecida. Por ser capaz de fazer reconhecer a verdade, a música por si mesma poderia ter um status racional. A linguagem verbal conseguia comover seus espectadores por meio da música.

O campo específico de imitação na música, para Dubos, eram os sentimentos:

Assim, pois, a música persegue o mesmo objetivo que as outras artes, e não só isso. Ademais, há uma cumplicidade e uma afinidade secretas entre música e sentimento, motivo pelo qual aquela se revela ante o último em uma posição mais ou menos privilegiada, e assim se estabeleceu a comparação entre a poesia e a pintura. À parte isso, diferentemente da poesia, que imita as paixões servindo-se de signos arbitrários instituídos pelos homens, que são as palavras, a música está dotada "de um potencial maravilhoso que nos comove", posto que os sons são "os verdadeiros signos da paixão, instituídos pela natureza, dos quais tem recebido sua força”. (Fubini, 2007, p.184, tradução nossa)

Como os sentimentos eram a expressão da natureza, imitados e evidenciados pela música, a ópera poderia se intitular como verdadeira e verossímil, embora a verdade para Dubos fosse a verdade dos sentimentos, e não a verdade racional. A ópera era o símbolo e a expressão dessa verdade, pois a função da razão era mover as paixões humanas, os afetos, ou seja, os sentimentos. A música faria isso de forma natural e direta, sem a mediação da razão. 
O autor deu um exemplo da ópera Thésée [Teseu], de Lully, a quem tinha como um compositor impecável, de como as palavras da poesia deveriam ser evidenciadas pela música:

La nature fournit elle-même, pour ainsi dire, les chants propres à exprimer les sentimens. Nous ne sçaurions même prononcer avec affection les vers qui contiennent des sentimens tendres et touchans sans faire des soupirs, sans emploïer des accens et des ports de voix qu'un homme doüé du génie de la musique, réduit facilement en un chant continu. Je suis certain que Lulli n'a pas cherché long-temps le chant de ces vers que dit Medée dans l'opera de Thesée.

Mon cœur auroit encore sa premiere innocence s'il n'avoit jamais eu d'amour.

Il y a plus. L'homme de génie, qui compose sur des paroles semblables, trouve qu'il a fait des chants variez, même sans avoir pensé à les diversifier. Chaque sentiment a ses tons, ses accens et ses soupirs propres. Ainsi le musicien en composant sur des vers, tels que ceux dont nous parlons ici, fait des chants aussi variez que la nature même est variée. (Dubos, 1993, I, §47, p.161)

[A própria natureza fornece, por assim dizer, os cantos apropriados para exprimir os sentimentos. Não conseguiríamos pronunciar com emoção os versos que contêm os sentimentos ternos e tocantes sem suspirar, sem empregar os acentos e os ports de voix ${ }^{9}$ que um homem dotado de gênio musical reduz facilmente a um canto contínuo. Tenho certeza de que Lully não procurou por muito tempo o canto desses versos que Medeia declama na ópera Thésée.

\section{Meu coração teria ainda sua primeira inocência}

Se jamais tivesse conhecido o amor.

9 Port de voix: o mesmo que portamento, quando o cantor liga uma nota à outra, como num glissando, num ligado mais sólido. 
E tem mais. Um homem talentoso que compõe usando palavras similares verifica que realizou cantos variados, mesmo sem ter pensado em diversificá-los. Cada sentimento possui seus tons, seus acentos e seus suspiros apropriados. Assim, o músico, compondo tais versos, como falamos anteriormente, produz cantos tão variados quanto os que há na natureza.] (Tradução nossa)

A música, ao tornar as palavras mais aptas a comover o espectador, faria superar o pensamento de que não teria outra função senão ser mero estímulo sensível, e nisso ela teria muito mais efeitos a produzir no espectador do que se este somente recebesse o estímulo de uma pintura bem feita ou de uma poesia muito bem versificada.

Quanto à música instrumental, como as relações entre música e sentimento eram estabelecidas sob o respaldo da linguagem verbal, ela ficou sem uma resposta definida em relação aos seus efeitos, quanto ao que imitava e ao seu âmbito estético, sem fazer uso do racionalismo ou das paixões. A resposta de Dubos para essa música, por conta do verbete "sinfonia"10 da Encyclopédie, era que ela imitava os ruídos existentes na natureza. Para ele, a música instrumental era ainda apenas uma preparação para as ações patéticas da ópera. Ela apenas reforçaria a comoção do espetáculo. O abade aceitava a "sinfonia", ou seja, a música instrumental, desde que funcionasse como uma preparação para a ação do drama, ou mesmo como uma introdução. A música instrumental, por si mesma, em sua concepção, ainda não estava apta a imitar os sentimentos existentes na natureza, mas, para aceitá-la, sua função era imitar então os ruídos

10 Atualmente, entende-se por sinfonia toda música instrumental, tanto as peças destinadas aos seus instrumentos, como as sonatas e os concertos, como aquelas nas quais os instrumentos misturam-se com as vozes, como acontece nas óperas. Podemos entender música vocal como uma música sem sinfonia, a não ser o baixo contínuo; a música com sinfonia tem pelo menos um instrumento, como violino, flauta ou oboé. Quando se diz que uma peça é uma grande sinfonia, ela contém os baixos e os altos, além de duas outras partes instrumentais. A música da capela do rei, a das igrejas e a das nossas óperas são quase sempre grandes sinfonias (Encyclopédie, 1734, §15, p.740, tradução nossa). 
que havia nela, desde que utilizada com funções específicas no contexto da ópera. Ela podia ser utilizada, mas, sem as palavras, não conseguiria mover as paixões.

Ainsi, quoique ces symphonies ne nous fassent pas entendre aucun son articulé, elles ne laissent pas de pouvoir joüer des rôles dans des pieces dramatiques, parce qu'elles contribuent à nous interesser à l'action, en faisant sur nous une impression approchante de celle que feroit le bruit même dont elles sont une imitation, si nous entendions ce bruit dans les mêmes circonstances que nous entendons la symphonie qui l'imite. Par exemple, l'imitation du bruit d'une tempête qui va submerger un personnage, à qui le poëte nous fait prendre actuellement un grand interêt, nous affecte comme nous affecteroit le bruit d'une tempête, prête à submerger une personne pour laquelle nous nous interesserions avec chaleur, si nous nous trouvions à portée d'entendre cette tempête veritable. Il seroit inutile de répeter ici que l'impression de la symphonie ne sçauroit être aussi sérieuse que l'impression que la tempête véritable feroit sur nous, car j'ai déja dit plusieurs fois, que l'impression qu'une imitation fait sur nous, est bien moins forte que l'impression faite par la chose imitée. (Dubos, 1993, I, §45, p.152)

[Assim, embora essas sinfonias não nos façam ouvir nenhum som articulado, não deixam de realizar seus papéis nessas peças dramáticas, porque contribuem para despertar o nosso interesse sobre a ação, produzindo em nós uma impressão semelhante àquela que produziria o próprio ruído do qual ela é uma imitação, se o ouvirmos nas mesmas circunstâncias em que escutamos a sinfonia que o imita. Por exemplo, a imitação do ruído de uma tempestade em que uma personagem vai submergir, pela qual o poeta faz que tenhamos um grande interesse, nos afeta como nos afetaria o ruído da tempestade pronta a devorar uma pessoa por quem temos um interesse afetivo, se estivéssemos prestes a ouvir essa verdadeira tempestade. Seria inútil repetir aqui que a impressão da sinfonia seria tão séria quanto a impressão que a verdadeira tempestade 
produziria em nós, pois já disse várias vezes que a impressão que uma imitação provoca em nós é menos forte do que a impressão produzida pela coisa imitada.] (Tradução nossa)

Ou seja, para manter a característica imitativa na música instrumental, Dubos havia concedido a ela, em seus argumentos, o poder de imitar os ruídos da natureza, e assim mesmo desde que sua utilização mantivesse a proposta de fazer entender o conjunto dramático de uma ópera:

En premier lieu, bien que cette musique soit purement instrumentale, elle ne laisse pas de contenir une imitation veritable de la nature. En second lieu, il y a plusieurs bruits dans la nature capables de produire un grand effet sur nous, quand on nous les fait entendre à propos dans les scénes d'une piece dramatique.

La verité de l'imitation d'une symphonie consiste dans la ressemblance de cette symphonie avec le bruit qu'elle prétend imiter. Il y a de la verité dans une symphonie, composée pour imiter une tempête, lorsque son chant, son harmonie, et son rithme nous font entendre un bruit pareil au fracas que les vens font dans l'air et au mugissement des flots, qui s'entrechoquent ou qui se brisent contre des rochers. Telle est la symphonie, qui imite une tempête dans l'opera d'Alcione de M Marais. (Dubos, 1993, I, §45, p.151)

[Em primeiro lugar, mesmo que essa música seja puramente instrumental, ela não deixa de conter uma verdadeira imitação da natureza. Em segundo lugar, existem vários ruídos na natureza capazes de produzir um grande efeito sobre nós quando ouvidos nas cenas de uma peça dramática.

A verdade da imitação de uma sinfonia consiste na semelhança desta com o ruído que pretende imitar. Existe a verdade em uma sinfonia, composta para imitar uma tempestade, enquanto seu canto, sua harmonia e seu ritmo nos fazem ouvir um ruído semelhante à trovoada provocada pelos ventos no ar ou o murmurar das ondas que se entrechocam ou colidem contra as rochas. Tal é 
a sinfonia que imita uma tempestade na ópera Alcyone, de Marin Marais.] (Tradução nossa)

Esse valor atribuído ao aspecto verbal nas óperas e a questão do lugar da música instrumental revelaram um problema difícil de sanar. Desde o começo do século XVIII, já com Raguenet, discutia-se se a música instrumental suscitava sensações e sentimentos, mas, por conta da tradição e dos costumes e da exigência de expressão da razão, somente a ópera era valorizada, considerando-se a música instrumental como mero suporte para realçar os sentimentos e as paixões contidos na poesia musicada. Dubos (1993) ainda fez uma comparação entre as duas formas:

Il est donc une verité dans les récits des opera, et cette verité consiste dans l'imitation des tons, des accens, des soûpirs, et des sons qui sont propres naturellement aux sentimens contenus dans les paroles. La même verité peut se trouver dans l'harmonie et dans le rithme de toute la composition. La musique ne s'est pas contentée d'imiter dans ses chants le langage inarticulé de l'homme, et tous les sons naturels dont il se sert par instinct. Cet art a voulu encore faire des imitations de tous les bruits qui sont les plus capables de faire impression sur nous lorsque nous les entendons dans la nature.

La musique ne se sert que des instrumens pour imiter ces bruits, dans lesquels il n'y a rien d'articulé, et nous appellons communément ces imitations des symphonies. Cependant les symphonies ne laissent pas de joüer, pour ainsi dire, differens rôles dans nos opera avec beaucoup de succès. (I, $\$ 45$, p.151)

[Existe, portanto, uma verdade nos recitativos das óperas, e essa verdade consiste na imitação dos tons, dos acentos, dos suspiros e nos sons que são propriamente naturais aos sentimentos contidos nas palavras. A mesma verdade pode ser encontrada na harmonia e no ritmo de toda composição. A música não se contenta em imitar, em seus cantos, a linguagem inarticulada do homem e todos os sons 
naturais dos quais se serve por instinto. Essa arte quis ainda fazer imitações de todos os ruídos capazes de causar uma impressão em nós quando os ouvimos na natureza.

A música somente se serve dos instrumentos para imitar esses ruídos, nos quais não há nada de articulado. Comumente chamamos essas imitações de sinfonias, e elas não deixam de cumprir, por assim dizer, diferentes papéis em nossas óperas, com muito sucesso.] (Tradução nossa)

A exigência feita por Dubos de que a música estivesse atrelada à linguagem verbal e o fato de atribuir valor inferior à música instrumental vinha da tradição vigente em sua época de se reportar a modelos da Antiguidade Clássica, pela qual a música deveria contar os mitos antigos e as suas histórias, e de reforçar a tese de que a declamação, que contava essas histórias no teatro antigo, e que o recitativo nas óperas tentava reproduzir, era constituída por uma notação musical precisa, que havia desaparecido do teatro em épocas posteriores:

Dubos se via obrigado a sustentar essa estranha tese devido à exigência de se querer que a música e a poesia se integrassem uma à outra de forma recíproca, pois os antigos, na opinião de Dubos, grandes conhecedores do princípio mencionado, consideravam que a poesia era complementada pela declamação, a saber, os acentos, os suspiros e as modulações que a haviam acompanhado durante a recitação. (Fubini, 2007, p.186, tradução nossa)

$\mathrm{Na}$ época em que o abade viveu, a música era uma arte mais ampla. Além de ter o escopo do teatro, também abarcava a dança, considerada a arte dos gestos, e a poética, cuja métrica era condicionada pela música para se constituir. A música estaria na origem da expressão artística, em união com a poesia, e ele a revalorizou, no sentido de ter trazido para ela a ideia de que sua linguagem era a dos sentimentos e, por isso, a música se mostrava genuína. 


\section{Batteux}

Charles Batteux, em sua obra Les beaux-arts réduits à un même principe [As belas-artes reduzidas a um mesmo princípio], de 1746, propôs um princípio único, o da imitação em geral, como regra a ser aplicada nas formas poéticas, nas artes plásticas e na música. Através de critérios racionais, buscou uma lei básica, única e abrangente para todas as regras poéticas e que fosse suficiente para explicar todo o universo artístico.

Batteux, assim como Dubos, ainda estava vinculado ao racionalismo do século XVII e ao discurso racional. Sua visão do conceito de imitação da natureza se constituía não apenas numa regra para a produção artística, mas também numa regra pensada com base em critérios racionais. A imitação, para ele, como para Dubos, possuía modelos estabelecidos na poesia da Antiguidade Clássica e seguia uma regra específica para cada fazer artístico.

Mas, ao mesmo tempo que ele ainda era um expoente do racionalismo advindo do século XVII e da tradição do teatro clássico francês do mesmo período, que teve como expoentes as figuras de Corneille e Racine, revelava também uma visão mais subjetiva, ao promulgar uma regra, um único princípio de unificação para todas as artes. Seu tratado demonstrou a passagem de uma objetividade racional para uma subjetividade ${ }^{11}$ intimista.

As regras objetivas para as artes, no que concerne ao poder imitativo, tiveram seu princípio questionado por um novo domínio da filosofia da poesia e da arte, o qual não mais aceitava essas regras

11 O termo "subjetividade" indica uma característica do sujeito, algo que é pessoal, individual, que pertence a ele e apenas a ele, sendo, portanto, inacessível a outrem e incomunicável. Outras acepções da palavra: interioridade, vida interior. A filosofia chama de "subjetivas" as qualidades segundas (o quente, o frio, as cores), pois não constituem propriedades dos objetos, mas "afetações" dos sujeitos que as percebem. Nenhum objeto é quente ou frio, cada um possui apenas certa temperatura. Toda impressão é subjetiva porque não se trata de propriedades dos objetos, não nos é dada pela experiência, mas pertence ao sujeito cognoscente, é a "forma a priori da sensibilidade" (cf. Japiassú, 2001, p.179). 
como fixas. Esse novo domínio foram os aspectos subjetivos ${ }^{12}$ como julgamento para o valor estético das obras de arte. Esses aspectos foram algo novo na época de Batteux e se tornaram um critério em meio às regras para os princípios da imitação, o que refletiu nas regras do bom gosto.

Todo fazer artístico partia da imitação da bela natureza como padrão de medida de sua produção. Além dos clássicos, a visão de mundo de Batteaux sobre as artes ainda estava comprometida com uma tradição ligada ao Antigo Regime e às aspirações heroicas que continuavam ressoando do reinado de Luís XIV (1643-1715). Por isso, em sua obra, ele defendeu os antigos, pois identificava-se com esses valores e com uma concepção hierarquizada de mundo e estava familiarizado com um tipo de escrita fundamentada no decoro. O compositor Jean-Baptiste Lully (1632-1687), cuja Tragédie lyrique correspondia aos ideais clássicos, era para Batteux um modelo insuperável para a música.

Assim, ele se encontrava num momento de transição entre a tradição racionalista e a subjetividade. Mesmo preso à tradição, os aspectos subjetivos em sua obra eram notórios.

No prólogo de seu tratado, Batteux (2009) escreveu as seguintes palavras: "Imitemos os verdadeiros físicos, que recolhem experiências e fundam em seguida sobre elas um sistema que as reduz a um princípio" (p.15). ${ }^{13}$ Essa afirmação demonstrou a relação que se fazia entre as artes e as ciências e como as leis das ciências se constituíram a partir da observação da natureza. Logo as artes também deveriam se constituir em leis universais, como ocorria com o pensamento da física com relação à natureza. Como todas as regras possuíam um mesmo tronco, cujo princípio era a natureza, segundo

12 O termo "subjetivo" refere-se ao sujeito do conhecimento, à consciência, à interioridade; é relativo ao indivíduo, à sua experiência individual. Exemplo: ponto de vista subjetivo (cf. Japiassú, 2001, p.179).

13 A tradução da obra As belas-artes reduzidas a um mesmo princípio, de Charles Batteux, foi realizada pelo professor doutor Marco Aurélio Werle, professor de Estética do Departamento de Filosofia da Faculdade de Filosofia, Letras e Ciências Humanas da Universidade de São Paulo. 
Batteux, logo esse se tornaria um princípio reconhecido pelo sentimento e seria a base e a explicação para a orientação de todas as artes.

Como princípio racionalista, a poesia, que deu origem a todas as artes, segundo a concepção da época, era o expoente da razão, que se manifestava pela linguagem verbal e orientava o discurso. Através dela, Batteux procurou unir os sentimentos à luz da razão. Esses dois elementos, sentimento e razão, eram o que ele buscava encontrar em todas as obras relacionadas com a poética. A poesia, como princípio literário, remetia a autores da Antiguidade que haviam produzido obras cuja forma deveria ser imitada nas regras do discurso. Embora muitos desses autores, como os latinos Sêneca e Horácio, tenham servido de modelo para a poesia nos séculos XVII e XVIII, foi a Poética de Aristóteles que norteou o princípio da imitação, e não somente isso: a Poética traria os meios de realização da imitação, já que tinha na tragédia a forma poética mais bem acabada, servindo também de base para a tragédia clássica francesa do século XVII, constituindo uma referência e um modelo para a literatura, o teatro e a ópera.

Batteux procurou aplicar em As belas-artes, segundo ele mesmo, à música e à dança, o princípio imitativo encontrado na Poética, afirmando que ele lhes convinha, embora a poesia ocupasse o lugar principal entre as artes. O objeto comum entre elas era a imitação da bela natureza, e, no caso da música, os meios para imitar a natureza eram os sons. Cada uma das artes usaria os próprios meios para imitar a natureza, mas todas eram "rebentos da natureza propondo-se o mesmo fim, regrando-se pelos mesmos princípios e, de outro lado, suas diferenças particulares, o que as separa e as distingue umas das outras" (Batteux, 2009, p.18).

Fora da esfera estritamente racionalista, que guiava o pensamento desde o século XVII, Batteux afirmou que as artes haviam ganhado uma natureza própria a partir do gênio ${ }^{14}$ do homem que as produziu,

14 Nesse contexto, a palavra "gênio" não deve ser compreendida segundo a concepção que seria estabelecida no século XIX, mas com o sentido de ingenium (engenho), proveniente de uma das partes da retórica, indicando a maneira "engenhosa" de construir o discurso. 
e de cada uma delas deveriam ser retiradas provas que agradassem ao gosto, e todas deveriam ser retiradas do sentimento, pois a razão havia estabelecido regras em função de se agradar ao gosto.

Estabelecer regras para o gosto, em relação ao que se desejava das artes, e regras para cada uma delas em particular era mais uma forma de dar maior grau de certeza para as normas do gosto. Sendo as mesmas regras existentes para as artes, as regras do gosto estariam de acordo com o princípio imitativo, pois as artes imitavam a bela natureza, ou seja, o bom gosto nas artes era o mesmo da natureza.

Para o autor, o princípio da imitação repousava primeiramente na premissa de que o artista não inventava objetos, não os imaginava, mas os encontrava, pois seu limite era a natureza, e a sua criação implicava em bem observá-la, e tudo o que produzisse seria tão somente fruto e consequência da imitação.

Imitar era, então, copiar um modelo, e este modelo era tudo o que existia na natureza. Ela constituía, portanto, o protótipo para as artes, pois apenas ela possuía todos os traços que poderiam agradar aos olhos e aos ouvidos, e esses deveriam ser transportados para objetos que não eram naturais. Assim, "o músico, com seus sons artificiais, faz bramir a tempestade, embora tudo esteja calmo" (Batteux, 2009, p.27), porém, as artes, para serem o que eram, deveriam apenas consistir em imitações, pois elas não eram a natureza, embora parecessem ser, e isso fez emergir outra afirmação: para parecer ser pelo uso da imitação, somente o verossímil constituía o seu material de realização artística, e não a verdade da natureza.

Assim, todas as artes, em tudo o que têm de verdadeiramente artificial, são apenas coisas imaginárias, seres fingidos, copiados e imitados segundo os verdadeiros. É por isso que se coloca incessantemente a arte em oposição à natureza, que se escuta em todo lugar apenas este grito, que é a natureza que é preciso imitar, que a arte é perfeita quando a representa perfeitamente, enfim, que as obras-primas da arte são aquelas que imitam tão bem a natureza que as tomamos pela natureza mesma. (Batteux, 2009, p.28-9) 
As artes, ao imitarem a natureza, permitiam o reconhecimento dos objetos existentes nela, e isso satisfazia ao gosto e ao sentimento, o que, na concepção de Batteux, só era possível pela imitação, pois as artes eram o quadro artificial das paixões humanas, também encontradas na natureza, e poderiam mexer com a fantasia do espectador diante da obra de arte.

Para Batteux, o espírito se exercia na comparação com o modelo; a inteligência cumpriria seu papel através do testemunhado e do reconhecimento do modelo imitado; e, se os costumes também eram usados nas produções artísticas, para que fossem copiados e reconhecidos pelo espectador, ele se aperfeiçoaria moralmente com isso. A imitação era artificial para as artes, mas com o uso dos costumes deveria ser real e moral para a sociedade, com o que Dubos também estava de acordo:

Por imitação, entendeu-se não uma cópia artificial da natureza, que consiste precisamente em representá-la, em arremedá-la [...], mas toda espécie de imitação em geral. De modo que esses termos, não tendo mais a mesma significação que outrora, deixaram de ser apropriados para caracterizar a poesia, e tornaram a linguagem dos antigos ininteligível para a maior parte dos leitores. De tudo o que acabamos de dizer, resulta que a poesia só subsiste por imitação. O mesmo ocorre com a pintura, a dança, a música: nada é real em suas obras, tudo é imaginado, forjado, copiado, artificial. É o que faz seu caráter essencial, em contraposição à natureza. (Batteux, 2009, p.30)

Quanto ao gosto, cuja função e forma de julgar implicava verificar se a bela natureza havia sido bem imitada, ele julgava as produções do gênio. Sua capacidade de prescrever leis para as artes era devida ao fato de limitá-las às leis das teorias imitativas. E se a imitação era comum a todas as artes, ela constituía o único ponto de união entre elas. Uma única parte dessas leis, uma vez reconhecida, levaria ao reconhecimento da sua existência em todas as outras artes, e isso só era possível através do gosto. 
O gosto é nas artes o que a inteligência é nas ciências. Seus objetos são diferentes em verdade, mas suas funções têm uma analogia tão grande entre si que uma pode servir para explicar a outra. $\mathrm{O}$ verdadeiro é o objeto das ciências; o das artes é o bom e o belo. (Batteux, 2009, p.49)

Para o autor, o gosto tratava da relação dos objetos de arte conosco, e a inteligência tratava dos objetos por eles mesmos. Por isso, o gosto era capaz de discernir entre o que era bom e o que era mau, entre o que era excelente e o que era medíocre, sem confundi-los, sem tomar um pelo outro, distinguindo-os com plena segurança. E, enquanto a perspectiva do gosto era a de sentir, a da inteligência era a de discernir, pela razão, entre o bom e o mau. A inteligência definia, enquanto o gosto sentia. "Assim, o verdadeiro e bom, conhecimento e gosto, eis todos os nossos objetos e todas as nossas operações. Eis as ciências e as artes” (Batteux, 2009, p.50).

Como o gosto era um sentimento, seu objeto eram as obras de arte, e estas consistiam em imitações da bela natureza. Assim, o gosto, como sentimento, deveria advertir-nos se a natureza havia sido ou não adequadamente imitada. Mas esse sentimento, em união com o gosto, embora devesse julgar as qualidades estéticas da obra de arte, precisava ser precedido pela luz da razão, da inteligência, e através dela descobrir as qualidades do objeto antes de se locupletar com as sensações agradáveis que ele poderia surtir no espectador.

Havia, assim, segundo Batteux (2009), dificuldades para harmonizar o gosto com a razão, pois

[...] a razão, quando se debruça sobre o sentimento, tem muita dificuldade em reconhecer sua causa. Talvez seja por isso que é tão fácil decidir a superioridade dos antigos sobre os modernos. É o gosto que deve julgá-la, e no seu tribunal se sente mais do que se prova. (p.50)

Por afirmar que o gosto era o sentimento no julgamento das artes, embora a razão orientasse as regras do fazer artístico pela imi- 
tação, sua estética foi julgada como uma estética dos sentimentos. Vamos verificar como a imitação se aplicou à música e à ópera.

A música também tinha seu fazer artístico baseado na imitação. O objeto dessa imitação era a bela natureza apreendida pelo ouvido. Sozinha, a música era considerada somente um canto. Para que este ocorresse, a música deveria estar associada à poesia, que empregava a palavra, a linguagem verbal, medida e calculada em tons. A música imitava pelos sons inarticulados, e a poesia, em associação com a música, imitava através da palavra medida. A música, reduzida em seu princípio mínimo, em sua expressão essencial, era vista como um canto. Como tal, fazia uso da poesia, angariando para si o elemento racional exigido das artes e o status de arte musical. Uma música, mesmo sem as palavras, continuaria sendo música, pois sua natureza eram apenas os sons.

Assim, a ópera, como um teatro, caso se tratasse de uma tragédia sem gestos, sem um cenário que remetesse à pintura, seria sempre um poema, e esse era o princípio de tudo. A expressão essencial da música era o som, e esta, como meio de imitar a natureza, não deveria fazer uso de todos os tipos de sons, mas escolhê-los de forma justa e aperfeiçoar os matizes emprestados da natureza de maneira requintada e harmoniosa. Segundo Batteux, os sons possuíam em si simpatias e repugnâncias, e a união arbitrária deles, que a natureza fazia pela própria vontade, também deveria ser feita na música, através de regras. Ainda, segundo o autor, seguir as regras era uma maneira de não ferir o gosto, e não somente isso: as regras utilizadas para a composição musical deveriam provocar o deleite no espectador.

Como a música usava de palavras, a mesma consideração feita para ela valia para a poesia, na qual a escolha certa das palavras proporcionaria uma harmonia que a linguagem corrente não possuía; ordenadas com destreza, elas trariam encantos que arrebatariam os ouvintes. A música então se fazia pela união das duas artes (música e poesia) que poderiam realizar empréstimos e ajudar uma à outra. Ou seja, na música e na poesia, a imitação da bela natureza se expressava por meio dos sons e da linguagem medida, mesmo que 
cada uma apresentasse características distintas, diferenciando-se uma da outra.

Na terceira parte de seu tratado [seção III: Sobre a música e a dança], Batteux comentou que a música havia sido uma arte maior do que fora na sua época. Disse que ela compreendia não apenas os sons, mas estava vinculada também à dança, à versificação e à declamação, e que, no período em que viveu, ela era tão somente expressa através do canto, já que, posteriormente, essas artes haviam sido separadas e a música tinha se reduzido apenas ao canto. Essa tese também foi defendida pelo Abade Dubos.

Batteux tratou a música em conjunto com a dança, com a justificativa de que a comparação entre elas permitiria melhor compreensão dessas duas artes e de que uma favorecia o esclarecimento da outra.

Devido aos ecos, no seu tratado, do Antigo Regime, da época de Luís XIV, a dança, para esse monarca, era até mesmo mais importante do que a música, arte que ele mesmo praticou como bailarino, muitas vezes, em comemorações e apresentações. A dança era considerada uma representação muito mais significativa da realeza e de sua aristocracia do que a própria música.

Batteux (2009) fazia uma distinção entre o gesto e a palavra. Considerava que o gesto tinha mais vantagem em relação à palavra, por ser mais natural, e que ele funcionava como uma espécie de dicionário da natureza, sendo mais compreensível, em muitas situações, do que a própria língua. No entanto, a palavra possuía o elemento da razão, a qual, somada ao gesto, adquiriu força natural e perfeição, pois a fusão das duas originou a medida, o movimento, a modulação e a harmonia.

A palavra nos instrui e nos convence, ela é o órgão da razão; mas o tom e o gesto são os órgãos do coração: eles nos comovem por meio das ideias às quais os sentimentos estão ligados e isso pela reflexão. $\mathrm{O}$ tom e o gesto chegam ao coração diretamente, e sem nenhum rodeio. Em resumo, a palavra é uma linguagem de instituição, que os homens fizeram para comunicarem mais distintamente suas ideias. (p.135) 
O que Batteux expressou nesse texto sobre a diferença entre gesto e palavra e a fusão dos dois é que as palavras adquiriram maior perfeição na arte da versificação quando ganharam o auxílio do gesto contido na dança e na música, e a versificação, por sua vez, tornou esses dois outros elementos mais perfeitos.

Para ele, a música deveria ser a imitação dos sentimentos ou das paixões, enquanto a poesia devia imitar as ações e, ao fazê-lo, estaria de acordo com a Poética de Aristóteles. A poesia era, então, o elemento racional, porque a ação seguia uma ordem lógica, racional. $\mathrm{O}$ autor escreveu:

[...] o objeto principal da música e da dança deve ser a imitação dos sentimentos ou das paixões, ao passo que o da poesia é principalmente a imitação das ações. Entretanto, como as paixões e as ações estão quase sempre unidas na natureza, e devem também encontrar-se juntas nas artes, haverá esta diferença para a poesia, e para a música e a dança: na primeira, as paixões serão empregadas como meios ou motivos que preparam a ação e as produzem; na música e na dança, a ação será somente uma espécie de tela destinada a carregar, sustentar, conduzir e ligar as diferentes paixões que o artista quer exprimir. (Batteux, 2009, p.136)

Mas Batteux não disse que a música deveria ser desprovida de sentido. Considerava que, se ela tinha algum significado antes de ser usada como apoio à poesia, ele deveria ser mantido. $\mathrm{O}$ sentido contido na música realçaria e tornaria o sentido das palavras mais enérgico e evidente. Pela riqueza de sentidos, os tons da música e os gestos da dança deveriam ser os mesmos para a expressão das paixões, as quais, para ele, não eram nem criadas nem destruídas, apenas regradas e aperfeiçoadas, desde que não houvesse o afastamento da natureza para exprimi-las.

Como a música deveria conter significados, precisaria ser observada, analisada e julgada como se fazia com um quadro: os traços nele conhecidos e reconhecidos, à semelhança dos objetos cujos elementos fazem sentido, deveriam ser buscados e encontrados na 
música. Segundo Batteux, se um músico pudesse apontar os trechos mais agradáveis de sua composição, mencionaria os trechos cantados, carregados de significados verbais.

Os trechos musicais mais familiares e as paixões humanas mais fáceis de apreender deveriam ser os mais utilizados pelo compositor, pois eram os mais apreciados pelos espectadores, segundo a visão do autor. O músico tinha a incumbência de retirar todos os seus sons e matizes da natureza, porque a todo o momento sua música seria comparada com a natureza. Em paralelo com a pintura, a música, se tivesse apenas ruídos, seria comparada a uma paisagem num quadro; e a que possuísse sons imbuídos de sentimentos, de paixões, compreensão racional, seria comparada à personagem da pintura:

Há sons na natureza que respondem à sua ideia, se ela é musical. Quando o compositor os tiver encontrado, ele os reconhecerá prontamente. Trata-se de uma verdade. Assim que a descobrimos, parece que a reconhecemos mesmo que nunca a tenhamos visto. E, quão rica seja a natureza para os músicos, se não pudéssemos compreender o sentido das expressões que ela abrange, ela não seria mais uma riqueza para nós. Seria um idioma desconhecido e, por consequência, inútil. (Batteux, 2009, p.140)

Se a música não tivesse nenhum significado, mesmo que fosse detalhadamente calculada e proporcional, ela não se assemelharia a um quadro, pois não tocaria a alma. Para ser compreendida, deveria ser como uma palavra vinculada a uma ideia. $\mathrm{O}$ seu discurso seria entendido, e as paixões seriam reconhecidas no canto musical. Batteux usou o exemplo da sinfonia, empregado também por Dubos, composição puramente instrumental, cujo elemento sonoro, por si só, possuía um significado primeiro e original que o tornava reconhecível à arte musical, que não apontaria seu verdadeiro significado por ser desprovido de canto e, assim, não se configuraria como uma pintura no coração humano. O canto deveria satisfazer ao coração, e era nisso que repousava o gosto. A música instrumental poderia imitar as paixões, mas seu sentido seria difuso e incompleto: 
[...] O coração tem sua inteligência independente das palavras, e quando ele é tocado, tudo compreende. Aliás, assim como há grandes coisas que as palavras não podem alcançar, há também as que são finas, que elas não podem apanhar; é sobretudo nos sentimentos que elas se encontram. (Batteux, 2009, p.141)

Aquilo que as palavras não poderiam expressar era compreendido através do gesto, pois seu significado era encontrado e reconhecido na natureza. E o sentimento compreendia a linguagem do gesto, segundo Batteux.

Para que a imitação ocorresse satisfatoriamente, como acontecia com as palavras na poesia, os significados dos sons da música deveriam ter as mesmas qualidades da elocução oratória, e ela deveria exprimir-se em conformidade com sua própria natureza. A "música imita o orador que emprega todas as figuras e variações de sua arte sem mudar o tom geral de seu estilo" (Batteux, 2009, p.143).

Quando se imitava, buscava-se uma expressão que o gosto julgaria. Conforme o autor, os traços escolhidos deveriam ser aperfeiçoados. Logo, o tom da voz, a violência das paixões, a postura da cabeça possuíam traços finos que iam além da sua compreensão como mera cópia, e nisso estava o deleite no reconhecido, o elemento surpresa que gerava contentamento, pois apenas a arte poderia aperfeiçoar o elemento encontrado na natureza. E, para o gosto, esses traços reanimariam o espírito.

Os tons da voz, na música, deveriam soar como novos em sua expressão, pois o ouvido trazia o sentimento ao coração com toda a força, e deveriam ser arrebatadores já na primeira audição, sendo inútil esperar uma segunda vez para que isso acontecesse, pois a alma se distanciaria de seus arroubos. As qualidades naturais dos sons da voz deveriam ser consideradas como as palavras na prosa. Daí as regras austeras estabelecidas para a música regularem sua naturalidade, a fim de aperfeiçoá-la, pois, desse modo, sua energia e sua graça seriam aumentadas, sem alterar o significado dos sons. A medida e o movimento estabelecidos pelas regras davam vida à composição musical, 
[... ] são como palavras preparadas e medidas para serem encaixadas em um verso. Em seguida, a melodia coloca cada um desses sons no lugar e na vizinhança que lhe convém: ela os une, separa-os, concilia-os, segundo a natureza do objeto que o músico se propõe a imitar. (Batteux, 2009, p.145)

Tudo deveria ser controlado, inclusive as paixões humanas, incontroláveis pela sua própria natureza, porém expressas pelas variações dos tons, dos intervalos e até mesmo das dissonâncias, que para Batteux (2009) deveriam entrar na composição musical da mesma maneira como existiam na natureza e serviriam como um tempero para caracterizar a música.

Nada é tão irregular quanto o comportamento das paixões, do amor, da cólera, da discórdia. Frequentemente, para exprimi-los, a voz se azeda e desafina de chofre e, por pouco a arte adoce esses desprazeres da natureza, a verdade da expressão consola sua dureza. Cabe ao compositor apresentá-las com precaução, sobriedade, inteligência. A harmonia, enfim, contribui para a expressão musical. Todo som harmonioso é triplo por sua natureza. Ele traz consigo sua quinta e sua terça maior; essa é a doutrina comum de Descartes, do padre Mersenne, do Sr. Sauveur e do Sr. Rameau, que faz dela a base de seu novo sistema de música. (p.145-6)

Mas essas irregularidades no comportamento das paixões deveriam parecer simples no canto da composição musical, também simples por natureza, e seus traços deveriam ser multiplicados, aperfeiçoados para se conseguir uma imagem rica e viva, o que tornava a imitação da bela natureza a mais perfeita possível.

Para Batteux, a música como linguagem das paixões e dos sentimentos, cuja imitação da natureza se fazia pelo critério da verossimilhança, era mais autônoma, menos rígida e literal em seu conceito de imitação do que para Dubos.

Sobre essa questão, escreveu Neubauer (1992): 
[...] Batteux define a música como um idioma independente das emoções e rejeita os princípios organizadores inerentes a ela; finalmente a considera como um meio expressivo e comunicativo comparável à linguagem. O ponto mais débil de suas ideias acerca da música não está naquilo que poderia conceber a música como uma pura construção, mas sim naquilo que se encontra em sua ideia segundo a qual a transformação mimética da natureza em uma bella nature [bela natureza] não é senão um refinamento da expressão, uma intensificação do poder da música produzida pela concessão da graça. As "regras austeras" da arte não constituem uma sintaxe harmônica, não transformam o material natural, senão que apenas se limitam a filtrá-lo. As verdades "possíveis" e "belas" são o resultado do refinamento, não de uma imposição das formas. (p.101, tradução nossa)

Para Dubos, a linguagem verbal era soberana em relação à música. Fundamentava-se nas leis da natureza que despertavam as paixões humanas. A expressão musical e artística deveria, então, imitar as emoções interiores e transformá-las em sinais exteriores. Devia imitar as paixões humanas, cujos modelos eram encontrados na natureza. Os sentimentos eram a linguagem da música. Expressos de maneira mais adequada por ela, nem sempre, segundo Dubos, seriam apropriados ou reconhecidos numa pintura ou mesmo na poesia.

Nous avons dit en parlant de la poësie du stile qu'elle devoit exprimer avec des termes simples les sentimens, mais qu'elle devoit nous présenter tous les autres objets dont elle parle sous des images et des peintures. Nous avons exposé en parlant de la musique, qu'elle devoit imiter dans ses chants les tons, les soupirs, les accens, et tous ces sons inarticulez de la voix, qui sont les signes naturels de nos sentimens et de nos passions. Il est très-aisé d'inferer de ces deux véritez, que les vers qui contiennent des sentimens, sont très-propres à être mis en musique, et que ceux qui contiennent des peintures n'y sont pas bien propres. (Dubos, 1993, I, §47, p.161) 
[Afirmamos, ao falar sobre poesia do estilo, que ela deve exprimir os sentimentos com termos simples, mas que deve apresentar todos os outros objetos dos quais fala em imagens e pinturas. Observamos, ao falar de música, que ela deve imitar, em seus cantos, os tons, os suspiros, os acentos e todos os sons inarticulados da voz, que são signos naturais de nossos sentimentos e de nossas paixões. É fácil inferir dessas duas verdades que os versos que contêm sentimentos são mais apropriados para a música, e que aqueles que contêm pinturas não são apropriados.] (Tradução nossa)

A música possuía certa autonomia, porque era um veículo que fazia sobressair os sentimentos, enaltecidos pela imitação, que despertavam e excitavam as paixões humanas. Dubos tinha na música instrumental apenas um recurso que reforçava a música vocal, a linguagem verbal, a palavra; evidenciava o texto poético, principalmente quando este se fazia ausente nos trechos cantados de ópera.

Para Batteux, a imitação era uma representação. ${ }^{15} \mathrm{~A}$ bela natureza era o elo comum entre as artes. A função da música era então imitar traços da natureza e aperfeiçoá-los, transformando-os em

$15 \mathrm{Na}$ sociedade francesa dos séculos XVII e XVIII, aquilo que era apresentado no palco, nas representações de ópera, contava com a adesão do "povo”, já que as personagens não eram diferentes daquelas da Antiguidade, que representavam as classes "mais altas" da sociedade, mas personificavam as várias hierarquias sociais do Antigo Regime. Japiassú (2001) traz a seguinte concepção de "representação": operação pela qual a mente tem presente em si mesma uma "imagem mental", uma "ideia” ou um "conceito" que corresponde a um “objeto externo”. A função de representação é exatamente a de fazer que a realidade externa venha à consciência, que se torne um objeto da consciência, estabelecendo a relação entre a consciência e o real. A noção de representação em geral contempla uma analogia com a visão e com o ato de formar uma imagem de algo. No caso, trata-se de uma “imagem não sensível, não visual”. Essa noção tem papel central no pensamento moderno, sobretudo no racionalismo cartesiano e na filosofia da consciência. Sob vários aspectos, entretanto, a relação de representação parece problemática, sendo por vezes entendida como uma relação causal entre o objeto externo e a consciência, por vezes concebida como uma relação de correspondência ou semelhança. A principal dificuldade parece estar no pressuposto de que a consciência seria incapaz de apreender diretamente o objeto externo. 
objetos não naturais, mas verossímeis com relação à natureza. Os modelos existentes na natureza serviriam para a produção de cópias para as artes, como verdades possíveis e reconhecíveis.

Como para Dubos, a música instrumental para Batteux poderia reforçar o texto poético, porém tinha maior autonomia para imitar os sentimentos. Para Dubos, a falta do texto traria dificuldades de classificação e significação para esse tipo de música, pois, sem ele, as paixões humanas seriam dúbias. Admitia que a música instrumental emocionasse, já que o princípio da música era o som em si, independente da palavra, mas com ressalvas, pois seria incompleta em seus significados, por não cumprir totalmente a função de imitar. A música instrumental poderia despertar as paixões humanas de maneira artificial, mas estas seriam incontroláveis e indefinidas, dada a sua incompletude e falta de significado, pois as paixões humanas eram orientadas e controladas pelas leis e pelas regras das teorias imitativas.

Fubini (2007, p.187) advertiu que nunca se discutiu tanto sobre imitação da natureza como no século XVIII e que o apelo à natureza ocultava, na verdade, um gosto em declínio, o que era muito mais evidente do que qualquer intento realista ou naturalista de manter as regras tradicionais. A natureza era então sinônimo de artifício e classicismo, evocando cenas pastoris e idílicas, cujas personagens, através de cenários, falavam com graça e inflexão elegantes, e na verdade expressavam o refinamento da nobreza da corte. A escolha dos melhores modelos da natureza demonstrava uma exclusão de tudo o que era considerado feio e desagradável na realidade.

Se a natureza pode atuar livremente, mesclando o prazer dos sons e das cores, na arte, em compensação, deve submeter-se às regras da imitação, conciliando exatidão e liberdade. Esta última deverá ser dosada com prudência, dado que uma pitada de liberdade anima a imitação, porém, se passar da medida certa, se incorrerá em anarquia, atropelando as regras do bom gosto. Compete à música - como já dissera Dubos - imitar os sentimentos e as paixões, enquanto a poesia imita as ações. (Fubini, 2007, p.187, tradução nossa) 
Entre Dubos e Batteux estabeleceu-se uma concepção de sentimento como um conceito autônomo e insubstituível, e a música adquiriu status de linguagem do sentimento. A partir deles, essa concepção se sedimentou, e a ruptura entre sentimento e razão tornou-se cada vez mais clara e profunda, separando-se tudo o que pertencia ao coração do que pertencia à razão. Aquilo que concernia ao coração era compreendido mais prontamente, pois bastava sentir. A música se tornou a linguagem universal do sentimento, sem a necessidade de intermediários, livre de convencionalismos.

\section{O pensamento de autores diversos: Grandval, Bollioud-Mermet e Blainville}

Não somente Dubos e Batteux expressaram suas reflexões sobre a imitação na música e nas artes como um todo, afirmando o poder da tradição e das regras das teorias imitativas segundo modelos estabelecidos. Outros autores fizeram circular seus pensamentos, embora, em muitos aspectos, houvesse total concordância com esses dois autores.

O conjunto de fragmentos de textos reproduzidos e analisados nesta parte do livro aponta inicialmente a exigência incisiva de se observar o cumprimento das regras das teorias imitativas da bela natureza para a composição das óperas, além de comentários que tinham esse aspecto imitativo como algo difícil de se completar e realizar totalmente. $\mathrm{O}$ compositor tido como modelo no que se referia à realização e ao cumprimento dessas regras, de acordo com o gosto da época, era Lully, considerado excelência nessa dimensão. Além disso, surgiram questionamentos sobre o conceito de gosto, sobre o combate à música italiana e o que era moralmente aceito na sociedade francesa.

Outro conjunto de fragmentos de texto revelou o pensamento de que se mantivessem as regras das teorias imitativas e do bom gosto, porém mais flexíveis no que se referia à aceitação da música instrumental, pelo menos no que concernia a imitar os ruídos da natureza, em acordo com Dubos e Batteux, e à maneira como as 
sensações eram suscitadas nos ouvintes através da música. Revelou-se também a ideia de que os italianos, até então negligenciados por aqueles que se opunham à inserção da sua música na cultura francesa, faziam um tipo de música instrumental e agrupavam os instrumentos da orquestra no palco de uma maneira que foi considerada superior àquela como os franceses faziam.

Por fim, observou-se, nas análises dos fragmentos de textos, uma comparação entre a música francesa e a italiana. Isso era considerado um problema, pois pensava-se que as comparações na verdade não deveriam existir. A música de cada país deveria ser observada e valorizada por si mesma. A música francesa buscava seguir regras concernentes às teorias imitativas, enquanto a ópera bufa italiana não se preocupava com isso.

Dubos e Batteux escreveram tratados sobre poética, estabelecendo regras para a composição das artes, sobre o que era esperado de seus autores e sobre o nível de formação erudita e culta daqueles que apreciavam os objetos produzidos segundo as determinações estabelecidas. Já no caso dos autores discutidos em paralelo a esses dois, encontramos textos que eram mais uma descrição de situações de momento, do comportamento daqueles que frequentavam a Ópera, e daquilo que era oferecido a esse público. Ou seja, esses textos funcionaram mais como uma prescrição, manutenção e correção do modo de se comportar e apreciar a ópera e na Ópera.

No entanto, na análise dos textos de época, verificou-se que o conceito de imitação na música apresentava problemas de classificação. Ora a música verdadeira era a vocal, ora valorizavam-se traços da música instrumental, mas era unânime a definição de música associada à linguagem verbal, quando do uso da poesia e do texto literário, na ópera. A música em si não era definida nessas discussões, apenas associada aos elementos da natureza como objetos a serem imitados na música vocal e instrumental, além de os sentimentos serem considerados a sua expressão.

A música era sempre associada a algum elemento externo a ela. Nos textos lidos nesta parte, as comparações com a música italiana, as regras de composição e imitação, o que era o bom gosto e o que 
era moralmente aceito trouxeram problemas de significação que se mantiveram mesmo depois que uma estética voltada aos sentimentos começou a suplantar o racionalismo.

O intento imitativo na ópera não satisfazia totalmente o que era esperado no que se referia ao cumprimento das regras. Ao mesmo tempo, no espaço de tempo de um pouco mais de vinte anos entre o primeiro e o último texto analisados aqui, a imitação como regra foi gradativamente se transformando e se tornando uma exigência menor, por conta da influência da música italiana na ópera francesa. $\mathrm{O}$ aspecto sentimental como linguagem da música, aceito já por Dubos e Batteux, foi uma via que aos poucos promoveu uma visão da música por ela mesma, como será observado posteriormente.

Vejamos a seguir o que outros autores disseram sobre música e como seus pensamentos se inseriram no momento histórico em que produziram seus textos.

Nicolas Ragot de Grandval (1676-1753) foi um cravista, compositor e autor dramático francês que trabalhou na Comédie Française. Dele temos os fragmentos do texto Essai sur le bon goust en Musique [Ensaio sobre o bom gosto em música], de 1732. Publicado um ano antes da segunda edição de 1733 das Reflexões, de Dubos, o seu texto tem muitos pontos em comum com o desse autor.

Para Dubos, os sentimentos constituíam o julgamento natural para a apreensão das belezas de uma obra de arte, mas sem perder de vista as determinações racionais, que deveriam ser satisfeitas pelas regras das teorias imitativas, além de com isso serem esperados efeitos passionais na audiência. Grandval (1732) compartilhou a noção de sentimento em conformidade com as regras, como podemos observar neste fragmento de texto:

Il y a (selon moi) deux grandes manieres de connoître les bonnes et mauvaises choses. Le Sentiment interieur, et les Regles. Nous ne connoissons le Bon et le Mauvais que par ces deux voïes. Ce que nous entendons, nous plaît ou nous déplaît.

Qu'on écoute ce sentiment interieur, on dira: il me semble que cela est bon, ou, il me semble que cela est mauvais. (p.1-2) 
[Existem (na minha opinião) dois grandes modos de conhecer as boas e as más coisas: o sentimento interior e as regras. Somente conhecemos o bom e o mau por essas duas vias.

O que ouvimos, ou nos apraz ou nos desagrada. Quando escutamos esse sentimento interior, dizemos: parece-me que é bom, ou parece-me que é ruim.] (Tradução nossa)

O julgamento que decidia se as coisas eram "boas" ou "más" vinha do conhecimento das regras, mas o prazer advindo do conhecimento deveria ser "sentido", reconhecido pelo sentimento, pois este saberia, pelas sensações, se as regras para as artes haviam sido cumpridas.

Grandval afirmou que preceitos estabelecidos deveriam ser observados, no que também estava em acordo com Dubos, pois reafirmava o cumprimento das regras das teorias imitativas, o qual determinava se uma música estava bem feita ou não. Como essas regras estavam sendo burladas na ópera francesa, por conta da maior influência da música italiana, procurava-se chamar a atenção para a manutenção delas, sempre de acordo com a tradição estabelecida desde o Renascimento, já que, como para Dubos, a tradição começava a ser esquecida, o que gerava um problema no reconhecimento de seus elementos perante as artes:

D'autre côté, les Maîtres, les Gens sçavans ont établi des Preceptes suivant les observations qu'ils avoient faites. C'est ce qui leur a parû de meilleur et de plus sûr. Ces Préceptes établis, sont ce qu'on appelle les Regles, et c'est par elles qu'on dira: cela est bon ou mauvais par telle ou telle raison.

Mais comme ce sont des hommes qui ont établi ces Régles, ils pouvoient se tromper. Leur autorité est considerable, mais enfin ce n'est pas une loi infaillible. (Grnadval, 1732, p.2-3)

[Por outro lado, os mestres, os eruditos estabeleceram os preceitos de acordo com as observações que tinham feito. É o que lhes pareceu melhor e mais seguro. Esses preceitos estabelecidos são o 
que chamamos de regras, e com base nelas podemos dizer: isso é bom ou ruim por tal e tal razão.

Mas, como foram os homens que estabeleceram as regras, eles podem ter se enganado. Sua autoridade é considerável, mas não é uma lei infalível.] (Tradução nossa)

O sentimento como noção para o julgamento das artes não era arbitrário. Ele deveria ser orientado, como observado por Dubos e Batteux, para que a apreensão dos efeitos das paixões humanas fosse eficaz. Apenas sentir não era suficiente. Porém, na medida em que se reconhecessem os modelos imitados na música, o efeito das paixões seria mais intenso e mais bem apreciado. Grandval afirmou que as falsas impressões recebidas durante a vida poderiam desviar o reconhecimento dos traços imitados da natureza, ou eles poderiam ser julgados erroneamente como advindos dela. $\mathrm{O}$ modelo que deveria ser reconhecido teria status de universal, pois qualquer pessoa que o conhecesse poderia reconhecê-la nos objetos que imitavam os seus traços. Sua universalidade estava ligada à poesia, pois esta, de acordo com Aristóteles (Livro IX da Poética), ${ }^{16}$ era universal. $\mathrm{O}$ perigo dessa concepção era não se reconhecer ou se enganar quanto ao que realmente a natureza poderia oferecer para a execução da obra de arte:

Le sentiment interieur n'est pas plus sûr, parce qu' on doit se défier chacun du sien. Qui ose se flater d'avoir un naturel heureux en qui les idées du Bon, du Beau, du Vrai, soient certaines et claires?

16 De acordo com Aristóteles: “[...] O historiador e o poeta não diferem pelo facto de um escrever em prosa e o outro em verso [...]. Diferem é pelo facto de um relatar o que aconteceu e o outro, o que poderia acontecer. Portanto, a poesia é mais filosófica e tem um caráter mais elevado do que a História. É que a poesia expressa o universal, a História, o particular. O universal é aquilo que certa pessoa dirá ou fará, de acordo com a verossimilhança ou a necessidade, e é isso que a poesia procura representar, atribuindo, depois, nomes às personagens" (Poética, Livro IX, 1451b). 
Nous pouvons avoir aporté au monde le fond de ces idées plus ou moins claires; mais nous avons reçû depuis notre naissance, mille fausses impressions, mille préjugés dangereux qui peuvent avoir affoibli en nous la voix de la bonne nature. (Grandval, 1738, p.3-4)

[Os sentimentos interiores não são seguros, devemos duvidar de cada um deles. Quem ousa se vangloriar de ter satisfação natural porque as ideias de bem, belo, verdadeiro mostrem-se corretas e claras?

Podemos ter trazido ao mundo a essência dessas ideias mais ou menos claras, mas recebemos, desde o nosso nascimento, mil impressões falsas, mil prejulgamentos perigosos, que podem enfraquecer a voz da boa natureza.] (Tradução nossa)

O sentimento, sem a orientação do conhecimento, prejudicaria o julgamento da obra de arte e não se apreenderia o verdadeiro bom gosto, pois "le bon goût se distingue à juger, par leurs degrez, les bonnes choses, les mauvaises, les médiocres, les excellentes et les détestables" (Grandval, 1732, p.5) [o bom gosto se distingue pelo julgamento, por suas gradações, as coisas boas, as más, as medíocres, as excelentes e as detestáveis] (tradução nossa).

O bom gosto só seria possível se fosse "purificado pelas regras", se estas fossem estritamente seguidas. Os objetos receberiam a maior estima possível, se tivessem sido obedecidas as regras das teorias imitativas da natureza. Para Grandval, não bastava apenas seguir as regras. Era necessário também possuir ouvido para apreender a música e ter conhecimento sobre música. Saber as regras, mas não conhecer música, seria um trabalho inútil, pois não se conseguiria reconhecer os traços imitados da natureza.

Il y a dans les Arts un point de perfection. Celui qui le sent a le Goût parfait. Celui qui ne le sent pas et qui aime en deçà ou au-delà, a le Goût défectueux. Ainsi donc, le bon Goût est le Sentiment naturel purifié par les Régles; il consiste à sçavoir estimer 
les choses ce qu'elles valent, et à s'y attacher à proportion qu'elles sont estimables. Mais, que faut-il pour acquerir ce profond discernement? Deux choses indispensables. Avoir de l'Oreille, et çavoir raisonnablement la Musique. Sans Oreille, on travaille en vain à se rendre connoisseur. (Grandval, 1732, p.7-8)

[Há nas artes um ponto de perfeição, quando aquele que a sente tem um gosto perfeito. Aquele que não a sente, ou sente aqui ou acolá, tem um gosto defeituoso. Assim, o bom gosto é o sentimento natural aperfeiçoado pelas regras. Ele consiste em saber estimar as coisas pelo que valem e relacioná-las às proporções em que podem ser estimadas.

Mas, o que é preciso para ter esse profundo discernimento? Duas coisas são indispensáveis: ter ouvido e conhecer razoavelmente música. Sem ouvido, trabalhamos em vão para nos tornarmos conhecedores.] (Tradução nossa)

Ao avaliar o quanto uma ária era capaz de agradar ao ouvido e ao coração, segundo o autor, não bastava se sentir seduzido pelo som ouvido. Deviam-se considerar as regras que definiriam se as impressões da natureza haviam sido bem captadas e se isso tinha sido feito com bom senso. Ao fazer isso e sentir que o coração tinha sido movido pelo sentimento, se a voz interior desse a sua aprovação, os sentimentos se refinariam.

O conhecimento sólido das regras e do bom gosto preparava a alma, segundo a concepção da época, para a apreensão das nuanças da música:

Pour juger juste, on doit commencer par écarter ces foiblesses. On doit porter une âme dégagée et prête à recevoir les impressions de la Nature et du bon Sens, et ne pas demander, ai-je du plaisir?

Il faut se demander à soimême; cet Air m'a-t-il flatté l'oreille? M'a-t'il émû le coeur? ouy. Voilà la voix du Sentiment interieur qui aprouve. Reste à consulter les Régles et à épurer ce sentiment par leur décision. (Grandval, 1732, p.17) 
[Para julgar de modo justo, devemos começar por desconsiderar essas fragilidades. Devemos ter a alma livre e pronta a receber as impressões da natureza e do bom senso, e não perguntar: eu tenho prazer?

É necessário perguntar a si mesmo: esta ária agrada aos meus ouvidos? Ela emocionou meu coração? Sim. Eis a voz do sentimento interior que aprova. Resta verificar as regras e refinar esse sentimento através da sua decisão.] (Tradução nossa)

Grandval afirmou que a música deveria ser natural, expressiva e harmoniosa. Para Dubos, a harmonia era um elemento atrativo, que contribuía para a expressão do ruído que a música buscava imitar. A expressão da música através da harmonia ganharia em termos de compreensão e seriam intensificados os efeitos do movimento das paixões humanas. A expressão atingiria seus propósitos na medida em que o texto poético, que imitava uma ação e orientava o discurso, fosse compreendido pelos ouvintes. A narrativa contida no texto musical, realçada pela música, seria cumprida através da razão, com o movimento das paixões. Novamente verificou-se uma concordância dos pensamentos do autor com os de Dubos:

Voici les grandes. Une Musique doit être naturelle, expressive et harmonieuse. Premierement, naturelle ou plûtôt simple, car la simplicité est la premiere marque du naturel. En second lieu, expressive. En troisiéme lieu, harmonieuse. Ce sont ces trois grandes Régles dont on a à faire l'aplication aux Airs que le sentiment interieur a approuvés, et ce sont elles qui décident en dernier ressort. (Grandval, 1732, p.18-9)

[Eis os grandes. Uma música deve ser natural, expressiva e harmoniosa. Primeiramente natural, ou melhor, simples, pois a simplicidade é a primeira marca do natural. Em segundo lugar, expressiva. Em terceiro lugar, harmoniosa. Estas são as três grandes regras que deveremos aplicar nas árias que o sentimento interior aprovou e são elas que decidem em definitivo.] (Tradução nossa) 
A concepção de bom gosto era de que este deveria ser requintado, regrado, mas guardar consigo o meio-termo. Com a retidão, conseguida com a razão, o julgamento da música seria o mais justo, além de útil e sólido. A vivacidade e a erudição apenas alcançavam extremos que não permitiriam observar os requintes do bom gosto, por isso o autor reiterou o valor de suas qualidades. Elementos como simplicidade, expressão e harmonia deveriam ser equilibrados e observados ao mesmo tempo na contemplação da música.

Percebeu-se em seu texto uma forte insistência em ressaltar a qualidade do bom gosto e o seu equilíbrio. Como a imitação nas artes e na música previa um modelo retirado da natureza, transposto para um objeto não natural, o prazer estava na verossimilhança, na ilusão provocada por esses objetos, porém, a moderação no gosto, sem os excessos da vivacidade e da erudição, tinha outra função: a de educar, a de moderar os comportamentos e manter os costumes. A função da imitação poderia ser a de iludir nas artes, mas na vida social ela deveria ser real, pois, como comportamento, seria imitada pela sociedade:

J'ai ouy dire, que de toutes les qualités, la Vivacité est la plus triviale et la plus commode: l'Erudition la plus chere et la plus dangereuse; la Droiture de jugement la plus solide et la plus utile, et le bon Goût, la plus rare et la plus exquise. Il faut du Chant, du naturel, et sur tout de la justesse d'expression. Il faut que le génie joüe; qu'il fournisse, mais qu'il n'abandonne jamais le vrai: autrement, quelque fécond qu'on soit, on est siflé. Comme il est plus facile de parler beaucoup que de parler juste, de même est-il plus aisé de beaucoup travailler, que de bien travailler. Il faut pourtant rendre justice à tout le monde. Disons que parmi les Musiciens d'Italie, il s'en trouve d'infiniment aimables, et qui sçavent joindre à la science (qu'ils possedent en general à un plus haut degré que nous) le beau Chant et le naturel. Il y en a, entr'autres, qui ont des symphonies charmantes. Je suis utoujours au guet pour attraper de leur Musique; je la cherche avec empressement, je la dévore avec avidité. (Grandval, 1732, p.24-6) 
[Ouvi dizer que, de todas as qualidades, a vivacidade é a mais trivial e a mais cômoda; a erudição, a mais palatável e a mais perigosa; a retidão do julgamento, a mais sólida e a mais útil; e o bom gosto, o mais raro e o mais requintado.

Deve-se tornar o canto natural e ajustá-lo à expressão. A ele se deve o talento que o toca e que, para obtê-lo, não abandona jamais o verdadeiro. Caso contrário, por mais que nos empenhemos, ele será um sussurro. Como é mais fácil falar muito do que falar com propriedade, é mais fácil trabalhar muito do que trabalhar bem.

Deve-se, portanto, render justiça a todo mundo. Dizem que entre os músicos da Itália são encontrados infinitos modelos que souberam juntar à ciência (que a possuem, em geral, em grau um pouco mais alto do que nós) o bom canto e o natural. Há neles, dentre outras coisas, sinfonias encantadoras. Sempre as observo para pegar de sua música, busco-as ansiosamente e devoro-as com avidez.] (Tradução nossa)

Outro elemento revelado nesse fragmento de texto foi a aceitação da música italiana, principalmente a instrumental. $\mathrm{O}$ autor mostrou que as "sinfonias" italianas produziam tal encanto que sempre despertavam o interesse do ouvinte, que buscava ouvi-las e apreciá-las pelo mero prazer, por serem agradáveis. Podemos deduzir que foi aceita uma música que não seguia os preceitos das regras das teorias imitativas, embora os franceses insistissem que os sons instrumentais deviam imitar os ruídos existentes na natureza. Além de elogiar a música instrumental, como o eram as sinfonias italianas, Grandval afirmou que os italianos tinham gosto, embora de outro tipo, porque souberam aliar a ciência ao canto e ao natural.

A apreciação da música e o seu conhecimento com o apoio da ciência já eram mencionados nas observações feitas nos textos. $\mathrm{O}$ autor aceitou a sinfonia e considerou-a encantadora, pois demonstrou sua apreciação por parte do público francês. Apreciada simplesmente por sua música, a sinfonia italiana não seguia uma regra de imitação. Para Dubos e Batteux, ela fazia sucesso e realmente excitava os sentidos, mas tiveram o cuidado de observar que o seu 
significado era difuso sem o uso da linguagem verbal. Grandval demonstrou que ela estava presente nas salas de concerto da época e era apreciada por si mesma.

$\mathrm{Na}$ medida em que a música instrumental foi sendo aceita pelos franceses como um elemento imitativo dos ruídos da natureza, pois o julgamento pelo critério do sentimento permitia sua apreciação, ela também deveria cumprir as regras estabelecidas, como as regras para a música vocal. Os franceses discutiam bastante a música pelo viés da comparação, e como para eles a sua música estava em conformidade com as regras, tomavam-na como base para julgar as outras músicas.

O raciocínio verificaria o cumprimento das regras, como dito anteriormente, e como elas se assemelhavam com a produção vocal e instrumental. Para os franceses, não era difícil identificá-las nas peças musicais. A comparação era uma prática tão comum entre eles que consideravam essa habilidade própria de uma pessoa de espírito. As peças instrumentais de caráter, também muito comuns entre eles, como as peças para cravo de Couperin e Rameau, que também utilizavam os recursos das teorias imitativas, fazendo alusão aos ruídos da natureza, como o arrulhar de pássaros e o ribombar das tempestades, deveriam seguir regras estritas para elas.

Grandval também fez recomendações sobre o nível de julgamento do conhecedor:

Vous ne voulez pas vous donner la peine de faire un jugement de raisonnement; faites un jugement de comparaison, à la maniere des Courtisans.

Il faut avoir bien dans la tête quelques morceaux de Musique de chaque caractere, bons et mauvais, mais bons et mauvais d'un consentement unanime; en connoître toutes les beautés et tous les défauts, et comparer à ces modéles ce que vous entendrez. Vous estimerez ceux-ci suivant qu'ils ressembleront aux autres, et l'idée de cette seule ressemblance, selon qu'elle vous frapera plus ou moins vivement, vous fera dire avec plus ou moins de force; j'aime cet Air, cette Symphonie ne me plait pas. Le connoisseur le plus habile ne 
doit point négliger de joindre aux jugemens de raisonnement, ces jugemens de comparaison dont il sortira une clarté très propre à affermir nos sentimens; et ce goût de comparaison dans une personne d'esprit, dans une personne du monde qui le sçaura faire valoir, pourra peut-être lui suffire. C'est une facilité flateuse pour la paresse, et une honnêtte ressource pour l'ignorance. (Grandval, 1732, p.37-9)

[Vós não deveis vos dar ao trabalho de fazer um julgamento de raciocínio, um julgamento de comparação, à maneira dos cortesãos.

Deveis ter em mente o caráter de algumas peças musicais, boas e más, mas boas e más segundo um consentimento unânime, deveis conhecer todas as belezas e todos os defeitos e comparar com esses modelos que ouvis. Agradar-vos-á saber que se assemelham umas às outras, e a ideia desta única semelhança, segundo vos comova com mais ou menos força, direis com mais ou menos força "amo esta ária”, "esta sinfonia não me agrada". O conhecedor o mais hábil não deve deixar de juntar, aos julgamentos de raciocínio, os julgamentos de comparação, os quais possuem uma clareza muito apropriada que ajuda a fortalecer nossos sentimentos. Esse gosto pela comparação numa pessoa de espírito, numa pessoa do mundo que o saiba fazer valer, pode ser suficiente. É uma facilidade para a indolência e um recurso honesto para a ignorância.] (Tradução nossa)

Sem um bom nível de conhecimento sobre música e sem um julgamento que contentasse ao bom gosto, assim mesmo as árias compostas com "defeitos", sem levar em consideração o valor das regras, acabavam agradando à audiência. Nesse momento, o público já era composto também por burgueses, e não somente pela classe aristocrática, que conhecia as regras das teorias imitativas, e desejava ver representados nos palcos os seus costumes. Essas árias "mal escritas", por agradarem mais devido ao fato de o seu prazer auditivo estar mais no coração do que nos ouvidos, eram aceitas como faltas cometidas segundo as regras, o que foi notado 
por Grandval, que procurou colocar o decoro instituído pela razão como o organizador da música vocal.

Quanto ao valor dessas árias aceitas apenas pelos encantos do coração, mas com "defeitos", segundo a razão, ele assim se expressou:

Présentement, jugeons des degrés de valeur des Airs. Il y a là dessus des préceptes. Premierement les manquemens contre les petites régles ne sont rien au prix des défauts contre les grandes. En second lieu, le plaisir du coeur étant au dessus de celui des oreilles, une Musique qui peche contre les loix qui vont à toucher le coeur, peche davantage que celle qui ne manque qu'à celles qui visent à contenter les oreilles. Pardonnons à deux cadences semblables, trop voisines l'une de l'autre; à quelques fautes contre les régles de la composition, et ne pardonnons point à un chant froid, ou forcé ou sans expression, ni à une Musique trop chargée d'agrémens, et pleine de richesses hors de saison. Tout cela est en pure perte. Les belles choses ne le sont plus, hors de leur place. La raison met les bienséances, et les bienséances mettent la perfection. (Grandval, 1732, p.47-8)

[No momento julgamos os graus de valor das árias, e o que existe acima desses preceitos. Primeiramente, as infrações das pequenas regras não são nada diante do preço de ir contra os grandes defeitos. Em segundo lugar, o prazer do coração está acima daquele dos ouvidos. Uma música que peca contra as leis que tocam o coração, peca mais do que aquela que busca contentar os ouvidos. Perdoamos duas cadências semelhantes, muito próximas uma da outra, qualquer falha com relação às regras da composição, mas não perdoamos o andamento de um canto frio, ou forçado, ou sem expressão, nem uma música muito carregada de adornos e cheia de riquezas fora de temporada. Tudo está perdido. As belas coisas não estão mais fora do lugar. A razão coloca decoro, e o decoro coloca perfeição.] (Tradução nossa)

Outro problema, além do cumprimento adequado das regras ou não, era o comportamento do povo. Grandval não só fez recomen- 
dações quanto ao cuidado que se deveria ter nas produções musicais, na maneira de imitar e no modo como o coração seria satisfeito com uma verdadeira imitação da natureza. Ele também observou o comportamento daqueles que frequentavam a Ópera e o modo como se manifestavam perante as apresentações e árias, capaz de atrapalhar a apreciação daqueles que estavam lá para julgar a ópera.

Podemos subentender, do próximo fragmento de texto, que ele não somente sugeriu que se seguissem os preceitos que agradariam ao gosto, mas que se levasse em conta que uma obra musical não seria para todos os públicos, fazendo alusão à antiga Atenas, onde nem todos podiam assistir aos espetáculos, como acontecia na França. Dubos manifestou a mesma preocupação quando escreveu, em seu tratado, que a tradição começava a ser esquecida e que uma educação peculiar aos nobres nesses lugares misturava-se com a educação de outras classes sociais, sem o mesmo acesso e educação aristocrática, que não se importavam com os requisitos do bom gosto, prova de que as teorias imitativas já não eram tão importantes e estritamente seguidas. Isso constituía um problema, já que nas representações havia a função de educação moral do cidadão e aprendizado dos bons costumes. Se a arte imitava modelos da natureza conforme as regras, o cidadão deveria imitar a conduta de vida e o comportamento em sociedade que ela representava.

Não bastava conhecer as regras e saber apreciá-las. Era preciso também ter educação para ter calma, pensava-se na época, para ouvir as árias, perceber os detalhes de sua composição e deixar-se arrebatar pelos sentimentos que ela suscitaria:

Pour les Airs des Opera, ou d'ailleurs, qui de la bouche des gens du monde passent dans celle de la populace, je soutiens que c'est une preuve sûre de bonté; et voici pourquoi: c'est qu'il a fallu que ces Airs qui ont plû aux honnêtes gens, ayent été chantés bien long-tems et bien universellement, pour avoir été apris par ceux qui les aprochent, qui les ont apris à d'autres, d'où à la fin ils se sont étendus aux Laquais et aux Servantes. Il a fallu que leur extrême vogue n'ait sçu être empêchée par les sçavans; au lieu qu'un Air 
qui a commencé parmi la populace, et qui ne se répand que parmi la populace, n'a que l'aprobation de la populace, et le petit peuple de France fort different de celui d'Athênes, et qui ne va point aux Spectacles comme cet autre y alloit, n'a pas le sentiment assez pur, pour mériter que son suffrage soit compté quand il est seul: qu'on le compte pour quelque chose quand il viendra à la suite des autres, à la bonne heure, pour lors ce sera une nouvelle preuve du dégré de beauté des ouvrages de Musique.

Enfin, pour se perfectionner le Goût, je crois qu'il faut écouter le raisonnement des sçavans, déferer aux sentimens des connoisseurs, et étudier les mouvemens du peuple.

Il reste encore une petite Régle. Comme avec tout ce que j'ai dit, nous ne serons pas si-tôt des juges sûrs; que nous pouvons nous tromper de tems en tems, nous nous ferons une habitude d'observer et d'éplucher nos méprises; nous éxaminerons quelquefois nos jugemens avec autant de rigueur que les ouvrages d'autrui; nous remonterons jusqu'à la cause de notre méprise que nous trouverons; et cette cause, nous la remarquerons nettement. Plus nous l'aurons bien remarquée, moins nous serons sujets à y retomber. L'utilité de cette pratique mene au bon Goût bien droit et bien vîte.

Quant aux moyens de conserver le bon Goût, ils sont les mêmes que ceux de l'acquerir; ce sera la pratique assiduë des maximes ci-dessus, qui nous le conservera après l'avoir acquis. (Grandval, 1732, p.58-61)

[Durante as árias de ópera, ou outras, que da boca das pessoas do mundo passem para aquela do povo, penso que se trate da prova de que são boas, e eis por quê: são essas árias necessariamente mais agradáveis para as pessoas honestas, que se cantam por mais tempo e bem universalmente, por terem aprendido junto daqueles bem próximos, os quais aprenderam-nas de outros, chegando-se, ao final, a ouvir aos lacaios e aos servos. É evidente que sua extrema popularidade não poderia ser evitada pelas pessoas instruídas. No lugar em que uma ária começou no meio da população, e se espalhou, e conta com a sua aprovação, o pequeno povo da França, bem 
diferente do de Atenas, que não vai aos espetáculos como esse outro ia, sem ter o sentimento suficientemente puro para merecer que seu sufrágio seja computado quando está sozinho: que seja computado quando surge na sequência de outros, em boa hora, porquanto será uma nova prova do grau de beleza das obras de música.

Enfim, para aperfeiçoar o gosto, creio que se deve escutar o que dizem os sábios, ao referir-se aos sentimentos dos conhecedores e estudar os movimentos do povo.

Resta ainda uma pequena regra. Diante de tudo o que foi dito, não seremos juízes infalíveis. Poderemos nos enganar de tempos em tempos, adquirir o hábito de observar e censurar os nossos erros. Às vezes examinamos nossos julgamentos com tanto rigor como analisamos as obras dos outros. Remontamos então à causa do nosso erro, e marcamos com realce essa causa. Quanto mais a tivermos bem à vista, menos seremos sujeitos a recair em erro. A utilidade dessa prática leva ao bom gosto aperfeiçoado e de modo bem rápido.

Quanto aos meios de conservar o bom gosto, eles são os mesmos daqueles necessários para adquiri-lo. Será a prática assídua das máximas anteriores que conservaremos após adquiri-las.] (Tradução nossa)

Por sua vez, o discernimento não estava relacionado apenas ao aprendizado do bom gosto. Também tinha a ver com o comportamento, pois os costumes deveriam ser representados nas óperas, segundo os documentos de época. Refinar o conhecimento era também refinar a educação e o comportamento em público. Havia uma preocupação extremamente cuidadosa com as aparências na sociedade, nesse período, e, com a ascensão da burguesia, o contraste dos costumes se fez presente, o que era combatido pelas classes aristocráticas. Dessa forma, os costumes também eram mantidos por meio da imitação dos exemplos demonstrados no palco, e, quando as árias já não possuíam o mesmo rigor das teorias imitativas, isso poderia ser um mau exemplo para os costumes: 
Si vous me demandez, après cela, à quelle marque vous pourrez connoître que vous possedez le bon Goût; je vous répondrai que votre demande est très-raisonnable. On doit être bien aise de pouvoir se flatter qu'on est parvenu à s'enraciner dans ce bon Goût si rare, puisque ce qu'il y a au monde de plus précieux, ce sont les Diamans et les Perles, après l'esprit de discernement, c'est-à-dire, le bon Goût. Cette douceur sera la récompense de nos soins, et c'est une douceur permise, pourvû qu'elle soit secrette, et qu'on ne la fasse pas éclatter par un air de suffisance et de présomption. (Grandval, 1732, p.62-3)

[Se vós me perguntardes, depois disso, qual categoria devereis conhecer para possuir bom gosto, responderei ao vosso pedido muito racionalmente. Deve ser bem agradável poder se vangloriar de criar raízes no bom gosto, algo tão raro, uma vez que o que existe de mais precioso no mundo são os diamantes e as pérolas, depois do espírito de discernimento, por assim dizer, do bom gosto. Essa suavidade será a recompensa pelos nossos cuidados, e é uma suavidade permitida, desde que seja secreta e que não se faça romper por uma aura de suficiência e presunção.] (Tradução nossa)

Ir à Ópera não era suficiente para a formação do bom gosto. Era também importante possuir discernimento para saber o que era bom e o que era ruim. Compreender quando uma obra era boa, mas mal executada, ou o contrário, era um requisito desejado e esperado dos seus apreciadores. Grandval afirmou que Lully era admirável por ser um dos compositores modernos que sabia produzir obras que alimentavam o espírito dos conhecedores com tons finos, delicados e expressivos, embora tenha afirmado que da Itália pudesse ser escolhida uma infinidade de árias que estavam em concordância com o que os franceses esperavam do bom gosto:

Discerner la bonté ou le mauvais d'une Musique, d'avec le bien ou le mal de l'execution. J'estimerois fort le Goût d'une personne qui me diroit sûrement: Cette Symphonie est belle, mais elle a été 
mal executée. Celle-ci a été bien executée, mais elle ne vaut rien. Cette distinction délicate ne se fait point sentir sans une finesse de discernement peu commune, et je croirois que ce seroit le Chef-d'oeuvre des Connoisseurs.

Je ne sçaurois trop le repeter; nourrissez-vous de bonnes choses, c'est-à-dire, à n'executer que de la Musique reconnuë bonne d'un consentement general, comme de celle de Lully, de celle de nos bons Modernes, et des Airs choisis de plusieurs Compositeurs d'Italie, dont il en est grand nombre d'estimables, et principalement des Symphonies.

Que Lully sur tout, soit votre pain quotidien; admirez l'esprit qui brille dans ses Ouvrages; il se montre par tout; ses Chants ne vous disent-ils pas qu'il étoit capable de penser ce qu'il exprimoit? Quels Tons fins, vifs, délicats, et expressifs! C'est ce qui s'appelle retoucher la Peinture de la Poësie; c'est en renforcer les couleurs. La pratique, l'application, et l'étude font les Ouvriers, mais il n'y a que l'esprit qui fasse les excellens Ouvriers. (Grandval, 1732, p.65-7)

[Discernir se uma música é boa ou ruim, se a sua execução é boa ou ruim. Conhecerei bem o gosto de uma pessoa que me diga seguramente: esta sinfonia é bela, mas foi mal executada, ou, então, ela foi bem executada, mas não vale nada. Essa delicada distinção não se percebe sem uma fineza de discernimento pouco comum, e acredito que isso seja o chef-d'oeuvre ${ }^{17}$ dos conhecedores.

Não será demais repetir: alimentai-vos de boas coisas, ou seja, executai apenas a boa música, assim reconhecida por consenso geral, como a de Lully, dos nossos bons modernos, e as árias escolhidas de muitos compositores da Itália, onde é grande o número das estimáveis, principalmente as sinfonias.

17 O termo chef-d'oeuvre equivale ao termo atual "carro chefe" quando quer dizer que algo é muito bem feito por alguém ou por um grupo de pessoas que têm como especialidade tal engenho. 
Lully, sobretudo, sabia de seu pão cotidiano. Admirai o espírito que brilha em suas obras, ele se mostra em toda parte. Seus cantos não dizem a vós que eram capazes de pensar e de exprimir? Que tons finos, vivos, delicados e expressivos! Isto é o que se chama retocar a pintura de uma poesia. É um reforçar das cores. A prática, a aplicação, o estudo são os trabalhadores, mas é com o espírito que se fazem os excelentes trabalhadores.] (Tradução nossa)

Além dos fragmentos de texto de Grandval, temos os de Louis Bollioud-Mermet (1709-1796), membro da Academia de Ciências, Letras e Artes de Lyon, no período de 1736 a 1793. Em 1746 foi publicado o seu texto De la corruption du goust dans la musique françoise [Da corrupção do gosto na música francesa], mesmo ano da publicação de As belas-artes, de Charles Batteux.

Nos fragmentos de seu texto, observamos a preocupação em destacar a existência de muitos artistas, assim como de grande número de pessoas que ficavam longe desses artistas nas representações. Embora houvesse grande tendência para a correção no que se referia às regras, assim como para a criatividade, ele afirmou que a música francesa estava em decadência, em decorrência da corrupção do gosto musical francês.

A produção musical e o público não estavam em comunhão, segundo a sua concepção. Bollioud-Mermet (1746) escreveu:

On peut dire, avec vérité, que les Arts ont fait depuis deux Siécles des progrès considérables. Les Modernes ont enchéri sur les Anciens; et nos fameux Artistes n'ont pas moins brillé en perfectionnant les découvertes de leurs prédécesseurs, que lorsqu'ils ont fait usage de leurs propres idées. En effet, jamais on n'a vû tant de génie pour la correction, pour l'imitation, pour l'invention.

Cependant, d'où vient que de tant d'Artistes il en est si peu qui approchent de la vérité, et que le plus grand nombre est de ceux qui s'en éloignent? La raison est, qu'ils tendent au même but par des routes différentes; que la plûpart négligent de suivre la seule qui y conduit; et que, dans la vuë de surpasser les plus habiles, ils se 
fraient de nouveaux sentiers dans lesquels ils s'égarent. (Bollioud-Mermet, 1746, p.3-4)

[Podemos dizer, com segurança, que as artes se constituíram depois de dois séculos de progressos consideráveis. Os modernos foram precedidos pelos antigos, e os nossos famosos artistas não são menos brilhantes no aperfeiçoamento das descobertas de seus predecessores quando usam suas próprias ideias. Com efeito, jamais se viu tanto gênio para a correção, para a imitação, para a invenção.

No entanto, por que surgem tantos artistas, se só poucos se aproximam da verdade, estando a maior parte deles tão distante dela? A razão é que eles possuem o mesmo propósito e querem alcançá-lo por diferentes vias. A maioria não segue aquilo que os conduz, e, visando aos mais hábeis, desenvolve novos caminhos dos quais se desvia.] (Tradução nossa)

Ele não poupou críticas também aos músicos, ao declarar que, em comparação com os grandes mestres, não eram coerentes com o fim a que se propuseram, de acordo com os meios de que dispunham. O resultado disso era uma música cujo conjunto, a seu ver, levava a música francesa à decadência, como podemos observar no seguinte fragmento:

Considérons donc le Musici'en, soit qu'il compose ou qu'il exécute: suivons-le dans l'exercice de sa profession: comparons sa méthode avec celles des plus grands Maîtres, ses moyens avec la fin qu'il doit se proposer; et, par les nouveaux effets qui résultent de ses efforts, voyons si au lieu de tendre à la perfection de son Art, il ne s'en éloigne point. Par ce moyen nous découvrirons les causes de son erreur, et les suites qui annoncent dans la Musique Françoise une décadence inévitable. (Bollioud-Mermet, 1746, p.6-7)

[Consideraremos, portanto, o músico como aquele que compõe ou executa. Seguir-lo-emos no exercício de sua profissão. Compararemos seu método com os dos grandes mestres, seus meios com 
o fim a que deverá se propor. E, para os novos efeitos que resultem de seus esforços, veremos se chegou ao lugar em que tende para a perfeição de sua arte, ou se ele se distanciou nesse ponto. Por esses meios descobriremos as causas de seu erro e as consequências, que apontam, na música francesa, para uma decadência inevitável.] (Tradução nossa)

Ao fazer sua observação sobre a corrupção na música e, claro, sobre a falta de exigência do público, que não conhecia as regras das teorias imitativas e não sabia reconhecer os traços da natureza no objeto imitado, ele se reportou também aos músicos e compositores, mencionando a corrupção do gosto tanto na composição musical como em sua execução. Quando a exigência, por parte do público, no que se refere à imitação, se tornou menor, e também se tornou menor por parte dos músicos, isso foi criticado pelo autor, que expressou o que esperava de um compositor, como observado na primeira parte de seu texto, reproduzida a seguir, da seção que tem o título Da corrupção do gosto na composição da música:

La première fonction du Musicien est la Composition: s'il veut exceller dans son Art, il faut nécessairement qu'il soit Harmoniste par régles et par principes. Les qualités les plus indispensables du Compositeur sont le génie, la méthode, le goût.

Le but qu'il doit se proposer dans son travail, est d'imiter la nature, de flater l'oreille, de toucher, d'élever le coeur; d'exciter à son gré les passions; de donner de l'ame, de l'expression à ses Chants; de les rendre nouveaux et variés, par les tours, par le beau choix des chordes et des sujets; d'exprimer avec justesse, avec élégance le sens des paroles, s'il compose de la Musique vocale; de prêter, pour ainsi dire, des paroles aux sons, et de la vie aux chordes, s'il travaille pour l'Instrumentale, en imitant par des traits vifs et animés, le tendre, le naturel de la voix.

En un mot, son objet principal doit être d'émouvoir et de plaire; de peindre d'après nature les mouvemens de l'ame, les affections du coeur; de varier ses modulations de telle sorte que son Harmonie 
satisfasse l'oreille, et soit avoüée par la raison. (Bollioud-Mermet, 1746, p.7-8)

[A primeira função do músico é compor. Se ele se sobressair em sua arte, deverá necessariamente ser harmonista, seguindo regras e princípios. As qualidades as mais indispensáveis para o compositor são o gênio, o método e o gosto.

A meta a que deve se propor em seu trabalho é a de imitar a natureza, de agradar ao ouvido, de tocar, de elevar o coração, de excitar, por sua vontade, as paixões, de dar alma e expressão aos seus cantos, de fazê-los novos e variados pela incursão, pela beleza dos acordes e dos temas, de exprimir com exatidão, com elegância, os sentidos das palavras; se compõe música vocal, de emprestar, por assim dizer, as palavras aos sons, de dar vida aos acordes; se trabalha o instrumental, imitando, pelos traços vivos e animados, a ternura, o natural da voz.

Em uma palavra, seu objetivo principal deve ser emocionar e agradar, pintar depois da natureza os movimentos da alma, as afeições do coração, variar suas modulações de tal sorte que sua harmonia satisfaça ao ouvido e seja confessada pela razão.] (Tradução nossa)

O autor tratou o compositor como se ele desconhecesse os princípios das regras imitativas, fazendo prescrições sobre como realizar a composição, dizendo que o trabalho dele tinha por finalidade a imitação da natureza e devia, portanto, excitar as paixões pela elevação do coração e o prazer dos ouvidos. Ele tentou explicar o que era condizente com a música vocal e como, com gosto e método, o compositor deveria dar vida ao texto poético de sua música, já que seu principal objetivo era emocionar e agradar, desde que admitido pela razão. Mais uma vez, sua manifestação demonstrou que a prática vigente já não se dava da mesma maneira como no século XVII e início do XVIII, pois prescreveu regras e normas que eram prática comum e recorrente na sociedade francesa. 
Para demonstrar que os franceses haviam tido grandes mestres na composição de óperas, ele recorreu ao exemplo de Lully, visto como um modelo para a música teatral, pois sabia realçar o texto literário do libreto de uma ópera, dando ênfase adequada aos significados das palavras em seus recitativos, e, mesmo na música instrumental, esta era feita com muito encanto, seguindo todo o requinte das regras das teorias imitativas:

Telle fut l'intention des grands Maîtres en ce genre. Tels furent les moyens qu'ils employèrent pour exceller. Lulli, que nous proposons hardiment pour le modéle de la Musique théatrale, nous a fait goûter dans ses Ouvrages les charmes séduisans de l'Harmonie. Le beau tour de ses chants, la noblesse, la force de son expression, sa manière aisée et naturelle de moduler, le caractère de ses Symphonies, la mélodie de ses Récitatifs, les graces naïves de ses Ariettes, et la belle ordonnance de ses Choeurs, lui attireront à jamais le titre de l'Orphée de notre Siécle. (Bollioud-Mermet, 1746, p.8-9)

[Tal foi a intenção dos grandes mestres neste gênero. Tais foram os meios que eles empregaram para sobressair. Lully, que nos propôs ousadamente o modelo da música teatral, nos fez experimentar, em suas obras, os encantos sedutores da harmonia. O belo volteio de seus cantos, a nobreza, a força de sua expressão, sua maneira simples e natural de modular, o caráter de suas sinfonias, a melodia de seus recitativos, as graças ingênuas de suas arietas, a bela ordenação de seus coros atraem para ele, como nunca aconteceu, o título de Orfeu do nosso século.] (Tradução nossa)

Assim como Batteux, Bollioud-Mermet revelou saudosismo em relação ao período de Luís XIV e comparou a era de Lully com o momento em que vivia, que, de acordo com o que expressou em seu texto, parecia menos brilhante e condizente com o que se esperava de um compositor, embora os sentimentos participassem como juízes da música desde meados do século XVIII, porém menos regrados. 
O seu saudosismo também remetia a outros compositores de música instrumental, como ele mesmo assinalou, cujo bom gosto se atrelava ao caráter que lhe era próprio. Reafirmou que a música se degenerou sensivelmente, a ponto de declarar que os franceses tinham deixado de ser franceses. A música já não imitava mais de acordo com as regras, como ocorria antes, e isso, para os partidários da opera seria, era um sinal da decadência:

La Musique instrumentale a eu aussi ses Coryphées. Senallié, Marais, Couperin, et plusieurs autres, se sont distingués dans la composition des Piéces et des Sonates. Le bon goût régne dans ces Ouvrages: chaque Instrument y trouve le caractère qui lui est propre avec les avantages qui le distinguent des autres, et qui les rassemblent tous néanmoins pour former les Concerts.

Voilà une légère idée du degré de perfection qu'avoit acquis la composition de la Musique dans ces derniers tems.

Mais, qu'on s'apperçoit bien que le Goût dégénère insensiblement! que dans la vûe de perfectionner cet Art, on le dégrade peu à peu: qu'à force de rafiner, de réformer, on a changé si considérablement la constitution de notre Musique, qu'on diroit qu'à cet égard nous avons cessé d'être François, ou que nous avons été transportés dans une autre région! (Bollioud-Mermet, 1746, p.13-4)

[A música instrumental teve também seus Corifeus. Senallié, Marais, Couperin e muitos outros se distinguiram pela composição de peças e sonatas. O bom gosto reina nessas obras. Cada instrumento traz consigo o caráter que lhe é próprio, com as vantagens que o distinguem dos outros, e todos são reunidos, contudo, para formar os concertos.

Aqui se tem uma ligeira ideia do nível de perfeição que havia alcançado a composição da música nesses últimos tempos.

Mas perceberemos que o gosto se degenera insensivelmente! Que, com vistas a aperfeiçoar esta arte, se degrada pouco a pouco. Que a força de refinar, de reformar, de alterar consideravelmente a constituição de nossa música, diríamos que nesse sentido deixamos 
de ser franceses, ou que fomos transportados para outro lugar!] (Tradução nossa)

O autor referiu-se à frequência com que os compositores procuravam fazer coisas novas visando somente ao sucesso e, para isso, usavam apenas o trivial, embelezado pela mistura de traços, sacrificando a nobreza e a expressão, empregando tudo o que o bom gosto repudiava. E, mais do que isso, a negligência das regras, que assolava o refinamento e a compreensão das palavras, era plenamente notada, mas aceita entre o novo público que frequentava a ópera e as salas de concerto:

Le Compositeur ne songe qu'à faire du neuf, et pour y réussir il met tout en usage. Il choisit des Sujets d'un chant bizarre et trivial, persuadé qu'il les embellira à force d'y mêler des traits, des variations, et des fredons.

Il sacrifie volontiers la noblesse, la simplicité de l'expression, à quelques saillies échappées à l'imagination que le bon Goût desavoue, mais que l'amour de la nouveauté fait hazarder. L'on s'accoutume, en composant, à négliger les Régles, à forcer les Caractères, à tordre le sens des paroles, à faire plus d'attention à un mot qu'à l'intelligence entière d'une phrase, à répéter sans discrétion un tour de chant qui cesse de plaire à force d'être entendu, à prodiguer sans ménagement le fard, l'artifice, le rafinement. (Bollioud-Mermet, 1746, p.15-6)

[O compositor sonha alcançar sucesso, e para isso ele faz de tudo. Escolhe os temas de um canto bizarro e trivial, convencido de que os embeleza ao misturar os traços, as variações e os trinados. Sacrifica voluntariamente a nobreza, a simplicidade da expressão, em favor de algumas projeções que escapam à imaginação e que o bom gosto desaprova, mas que o gosto pela novidade faz arriscar.

Ele se acostuma a negligenciar as regras ao compor, a forçar os caracteres, a distorcer o sentido das palavras, a dar mais atenção a uma palavra do que a toda a inteligência compreendida em uma 
frase, a repetir sem parcimônia uma quantidade de cantos que deixam de agradar à força ao serem ouvidos, a prodigalizar sem cerimônia a ilusão, o artifício, o refinamento.] (Tradução nossa)

Bollioud-Mermet, em suas manifestações, chamou a atenção para o que se tornou a imitação da bela natureza. Afirmou que ela já era vista pelos compositores como algo comum e que, ao utilizarem a imitação, faziam-no de modo displicente, buscando, a seu ver, aquilo que havia de feio na natureza, assim como o bizarro. Os nobres procuravam, nas representações no palco, se livrar de tudo o que havia de feio na sociedade, e projetaram um mundo ideal como norma para os bons costumes. O autor assinalou que o inverso ocorria, que se faziam más escolhas para executar a imitação. Ressaltou que havia defeitos na composição ao se exigir o uso das extremidades vocais e que, mesmo nas passagens direcionadas à música instrumental, a desordem era visível:

L'imitation de la nature est un chemin trop battu, un moyen usé et trop commun. Le génie du siécle consiste à se livrer à tout ce qui ne ressemble à rien. Si le Musicien copie la nature, c'est moins pour faire usage des images nobles et riantes qu'elle nous offre, que pour montrer ce qu'elle a de laid et de bizarre. Il affecte d'imiter le cri des animaux les plus vils, ce qu'il y a de plus commun, de plus difforme dans les effets naturels; ensorte que le mauvais choix des modéles fait tort au mérite de l'imitation.

On ne cherche plus à tirer des Voix et des Instrumens ce qu'ils peuvent produire de flateur. On ne pense point à les faire paroître avec avantage. On travaille au contraire à étendre les bornes des uns, à reculer l'étendue des autres. On prend plaisir à forcer les limites de la Voix; à toucher des tons dans les extrémités où les plus étenduës sont défectueuses: comme des téméraires qui abandonneroient le bon chemin pour se promener au bord des précipices. On fait exécuter à ces Voix des intonations bizarres et détournées, des passages, des batteries réservées aux Violons.

(Bollioud-Mermet, 1746, p.16-7) 
[A imitação da natureza é um trajeto demasiado conhecido, um meio muito usado e por demais comum. A genialidade do século consiste em se livrar de tudo o que não se assemelha a nada. Se o músico copia a natureza, é menos por fazer uso das imagens nobres e risonhas que ela nos oferece, e mais para mostrar o feio e o bizarro que há nelas. Imitar o grito dos animais os mais vis, o que há de mais comum, de mais disforme nos efeitos naturais, faz que as más escolhas dos modelos tornem errôneo o mérito da imitação.

Não se procura mais extrair das vozes e dos instrumentos aquilo que podem produzir de agradável. Não se pensa fazê-los aparecer com vantagem. Trabalhamos não para estender os limites de alguns, mas para fazer recuar a dimensão de outros. Temos prazer em forçar os limites da voz, em tocar os tons nos extremos em que as maiores extensões são defeituosas, como as temeridades que abandonam o bom caminho para caminhar à beira dos precipícios. Fazemos que essas vozes executem entonações bizarras e desviadas, passagens, estrondos reservados aos violinos.] (Tradução nossa)

Bollioud-Mermet (1746) faz uma espécie de lamento ao relatar que não existia mais o gosto ditado pela natureza:

Quel succès peut-on raisonnablement attendre d'une pareille Musique? où la mode, la fantaisie, l'inconstance donnent le ton? où le Goût dicté par la nature, cultivé par les plus habiles, est négligé?

Mais si la composition de la Musique reçoit des changemens qui la dégradent, elle éprouve encore dans l'exécution une altération plus considérable. (p.21)

[Qual sucesso podemos racionalmente esperar de tal música? Em que a moda, a fantasia, a inconstância definem o tom? Onde o gosto ditado pela natureza, cultivado pelos mais hábeis, é negligenciado?

Mas, se a composição da música recebe essas alterações que a degradam, ela experimenta ainda na execução uma alteração mais considerável.] (Tradução nossa) 
Na segunda parte de seu texto, o autor se referiu à corrupção do gosto na execução musical. Refletiu sobre aquilo que não fazia parte dessa arte, mas que havia se tornado de uso corrente na música. E, se ainda não era pior a maneira displicente de tratar a música, era porque o compositor estava mais preocupado com a sua maneira de compor, por ter de seguir obrigatoriamente os rastros de outros compositores famosos e bem sucedidos que o precederam. O problema estava no fato de que a corrupção musical ocorria entre os executantes, que não procuravam reproduzir a música de acordo com o que o compositor havia escrito. Mas, como o público era menos conhecedor das regras do bom gosto, como mencionado anteriormente, a má execução era vista muitas vezes como perfeita, o que, para o autor, se mostrava como a degradação da música francesa de seu tempo, como veremos em fragmentos selecionados da segunda parte de seu texto:

Pour juger de la décadence du Goût à l'égard de l'exécution de la Musique, il convient de faire réflexion qu'il n'en est pas de cette partie de notre Art, comme de la première. Pour la perfection de celle-ci, la méthode, le Goût suffisent; le génie y a peu de part.

Par cette raison la Corruption du Goût y est plus à craindre, et plus générale, parce qu'elle est plus facile. L'Ecrivain est gêné, et n'ose pas hazarder toutes les libertés que se permettent les Musiciens qui exécutent. Les Régles le contraignent encore, et l'obligent à suivre les traces des fameux Artistes: au lieu que le Musicien exécutant substituë son goût à celui de l'Auteur, employe à son gré, et impunément, toutes les variations que son caprice lui suggére: Abus très-commun dans ce Siécle.

Le vrai Goût demande cependant que celui qui exécute, suive à la lettre l'intention du Compositeur; qu'il entre par son expression dans l'esprit de la Piéce composée, dont tout le mérite dépend de la manière avec laquelle elle est renduë. C'est une espéce d'infidélité, que l'oreille sçavante ne pardonne point, que d'ajouter, retrancher, falsifier la Musique d'autrui; c'est ce que font hardiment la plûpart 
de nos Musiciens. Ils viennent à bout d'altérer la plus saine Harmonie, la Mélodie la plus flateuse, et cela par trois défauts dans l'exécution, dont ils s'applaudissent comme s'ils eussent trouvé des moyens de perfection. (Bollioud-Mermet, 1746, p.22-4)

[Para julgar a decadência do gosto, com respeito à execução da música, convém fazer uma reflexão sobre aquilo que não faz parte da nossa arte, como fazia da primeira. Para alcançar a perfeição, o método, o gosto necessário, o gênio são uma pequena parte.

Por essa razão, a corrupção do gosto é mais temerosa e mais geral, porque é mais fácil. O compositor é constrangido a não se arriscar a usar todas as liberdades permitidas aos músicos que executam. As regras o forçam a seguir os rastros dos artistas famosos. Quando o músico executante substitui seu gosto pelo do autor, emprega-o de acordo com a sua vontade e, impunemente, faz todas as mudanças que seu capricho lhe sugere, esses são abusos muito comuns neste século.

O verdadeiro gosto demanda, entretanto, que se execute seguindo à letra a intenção do compositor; que se entre por meio de sua expressão no espírito da peça composta, do qual todo o mérito depende da maneira como é feita. É uma espécie de infidelidade, que o ouvido não sabe perdoar, ao adicionar, subtrair e falsificar a música dos outros. É isso que faz, de modo ousado, a maior parte dos nossos músicos.

Depois eles alteram ainda mais a saudável harmonia, a melodia mais agradável, e esses três defeitos na execução são aprovados, como se tivessem encontrado os meios da perfeição.] (Tradução nossa)

Essa degradação tornou-se ainda mais evidente quando o autor comparou o que teria sido a música entre os espartanos da Grécia Antiga e incentivou a que se observassem os "grandes mestres" do passado, pois isso permitiria reviver o gosto já existente e que estava degradado em sua época. Bollioud-Mermet (1746) assim se expressou: 
C'est donc là le point de dégradation, où le rafinement a conduit la Musique? Nous ne sommes plus, il est vrai, dans les Siécles où l'on la mettoit au rang des choses importantes.

Les Spartiates condamnèrent autrefois à l'amende et à la peine de l'Ostracisme le Musicien Thimothée, parce que pour enchérir sur Simonides, il avoit fait quelque augmentation de Chordes à la Lyre. La Republique le jugea punissable d'avoir introduit une nouveauté superflue, qui changeoit la forme et la nature de la Musique Lacédémonienne.

Les altérations que quelques Artistes causent à notre Musique, n'intéressent pas assez sérieusement le Public, pour mériter des châtimens. Les révolutions des Arts destinés aux plaisirs des hommes font un léger préjudice à la Société, et restent dans l'ordre des choses indifférentes.

Mais l'amour du vrai, les charmes de la belle simplicité, le cri de la nature, l'autorité des grands Maîtres, l'expérience et le témoignage des sens devroient préserver la Musique des vicissitudes qui la dégradent. On ne peut opposer pour toute punition aux Musiciens novateurs que le ridicule de leurs innovations. C'est, je pense, le moyen le plus sûr de ranimer le bon Goût qui s'éteint.

Tout ce que je viens d'exposer à l'égard des travers où se jettent les Musiciens de nos jours, sert à découvrir les vraies causes de la Corruption du Goût dans la Musique Françoise. (Bollioud-Mermet, 1746, p.37-9)

[É este, portanto, o ponto de degradação a que o refinamento conduz a música? Nós não estamos mais, é verdade, nos séculos em que estava entre as coisas mais importantes.

Os espartanos condenaram, no passado, à multa e à pena de ostracismo, o músico Timóteo, porque, para agradar a Semônides, ele aumentou um pouco a quantidade das cordas da lira. A República o julgou punível por ter introduzido uma novidade supérflua que alterou a forma e a natureza da música lacedemoniana.

As alterações que alguns artistas fazem na nossa música não interessam tão seriamente ao público para merecer punições. As 
revoluções nas artes destinadas aos prazeres dos homens são um legado prejudicial à sociedade e permanecem na ordem das coisas indiferentes.

Mas o amor ao verdadeiro, os encantos da bela simplicidade, o grito da natureza, a autoridade dos grandes mestres, a experiência e o testemunho dos sentidos deveriam preservar a música das vicissitudes que a degradam. É, penso eu, o meio mais seguro para reavivar o bom gosto em extinção.

Tudo o que acabei de escrever perpassa para onde se lançam os músicos em nossos dias e serve para desvendar as verdadeiras causas da corrupção do gosto na música francesa.] (Tradução nossa)

Para o autor, embora tenha reconhecido o bom gosto na música italiana, o problema estaria em uma espécie de febre que levou os franceses a imitar os "estrangeiros" - nesse caso, os italianos -, o que transformou o gosto francês em algo "bizarro". Ele acusou os franceses de negligenciar o próprio gosto em detrimento daquele dos italianos, que considerava pior. E questionou o que os italianos produziam de tão bom que justificasse que fossem imitados pelos franceses, e declarou que, provavelmente, eles jamais imitariam os franceses.

Em sua discussão sobre a corrupção do gosto na música francesa, voltou a falar sobre a imitação da natureza:

Enfin, l'on change la forme de notre Musique, parce qu'on aspire trop à l'imitation des Etrangers. C'est là l'écueil de nos Musiciens. Le Goût Italien les séduit tellement, qu'ils le répandent sans discernement dans leur jeu et dans leurs compositions. Ils prêtent même souvent aux Italiens, en voulant les imiter, des défauts qu'ils n'ont pas. La bonne Musique Italienne n'est point si bizarre qu'on nous la suppose. Corelli nous servira d'exemple.

Cet excellent Homme a mis lui seul dans ses Oeuvres plus d'Harmonie, plus de ces beaux Chants dictés par la nature, qu'on n'en trouveroit peut-être dans toutes les Sonates de nos Harmonistes. Ils font un mélange bizarre et mal assorti du Goût François 
et de l'Italien: tandis qu'ils négligent de faire valoir le premier, comme le talent que la naissance leur a donné, et pour lequel ils ont plus de dispositions. Car il ne faut pas se flater jusqu'au point de croire que nous imitions bien la manière Italienne: il ne nous est pas possible d'en juger. Mais les Italiens sentent bien la distance qui nous éloigne de leur génie, et de leur Goût qu'il nous sera toujours impossible de saisir.

Nous pouvons cependant nous former une idée du ridicule de cette fausse imitation, par celui que nous trouverions dans un Italien qui voudroit copier la Musique Françoise. Il nous serviroit de risée: portons de nous-même ce jugement. Au reste, cette Nation est en ce point plus sage que la nôtre. On n'entend pas dire, à parler généralement, qu'elle tende à nous imiter en ce genre.

D'où vient donc que le François fait si peu de cas de son Goût, qu'il lui préfére celui des Etrangers? Chaque Peuple traite les Arts selon son génie. Laissons les Italiens avec leurs manières, sans les trop admirer, ni les condamner; et bornons-nous à maintenir, à perfectionner les nôtres. (Bollioud-Mermet, 1746, p.42-4)

[Enfim, para alterar a forma da nossa música, é porque aspiramos também à imitação dos estrangeiros. É esta a armadilha para os nossos músicos. O gosto italiano os seduz, de modo que eles o divulgam sem discernimento em seu toque e em suas composições. Eles fazem empréstimos com frequência dos italianos, querendo imitar os defeitos que não têm. A boa música italiana não é tão bizarra quanto supomos. Corelli nos servirá de exemplo.

Esse excelente homem somente colocou em suas obras mais da harmonia, mais dos belos cantos ditados pela natureza, como talvez não encontremos em todas as sonatas dos nossos harmonistas. Elas são uma mistura bizarra e mal combinada do gosto francês e do italiano, tanto que deixam de fazer valer o primeiro, como o talento que receberam pelo nascimento, e para o qual eles têm mais disposições. Pois não se deve iludir-se a ponto de acreditar que imitamos bem à maneira italiana, não nos é possível julgar. Mas os italianos 
percebem bem a distância que nos afasta de seu talento e de seu gosto, o que nos será sempre impossível apreender.

Poderíamos, no entanto, ter uma ideia do ridículo dessa falsa imitação se encontrássemos um italiano que quisesse copiar a música francesa. Isso seria zombaria: temos essa ideia de nós mesmos. De resto, esta nação, nesse aspecto, é mais sábia do que a nossa. Não ouvimos dizer, não se fala, em geral, que ela tende a nos imitar nesse gênero.

Por que então o francês faz pouco caso de seu gosto, que ele prefere ao dos estrangeiros? Cada povo trata as artes de acordo com o seu talento. Deixemos os italianos com as suas maneiras, sem admirá-los muito nem condená-los, e limitemo-nos a manter e aperfeiçoar as nossas maneiras.] (Tradução nossa)

Ainda sobre o seu saudosismo com relação ao período de Luís XIV, Bollioud-Mermet (1746) escreveu:

Le Siécle de Loüis XIV, me dira quelqu'un, est donc à votre avis le dernier période de la perfection de la Musique? Il faudra donc en rester là, et ne plus penser à y rien ajouter? Cependant, en matière de Goût, les temps varient à leur gré les usages: l'on ne sçauroit rien déterminer à cet égard, et les comparaisons d'un Siécle avec un autre ne prouvent rien contre le Goût dominant. (Bollioud-Mermet, 1746, p.44-5)

[O século de Luís XIV, me dirá qualquer um, é, na sua opinião, o último período de perfeição da música? Será necessário permanecer lá e não pensar em adicionar mais nada? No entanto, em matéria de gosto, os tempos mudam os usos à sua vontade. Nada podemos determinar a esse respeito, e as comparações entre um século e outro nada provam contra o gosto dominante.] (Tradução nossa)

O autor mencionou que a arte, na sua época, ganhou o status de ciência, que os instrumentos musicais ganharam em leveza, que os métodos de canto tornaram as vozes mais limpas e potentes. Se, por 
um lado, tecnicamente, as áreas da música se desenvolveram, por outro, o gosto, em sua concepção, perdeu bastante, ao se comparar a composição à de autores anteriores, como Lully e Delalande. A teoria da arte e a técnica ganharam muito, mas o gosto perdeu consideravelmente. O novo introduziu muitas inovações, segundo o autor, mas não suplantou o velho.

On me demandera: Mais quel est ce Goût? à quels signes certains le distingue-t-on? Je répondrai que sans entreprendre de donner une définition courte et exacte du bon Goût en tout genre, je pense qu'à l'égard des Arts et de la Musique, le bon Goût est ce qui est conforme à la nature; ce qui est approuvé par la raison; ce qui n'est, ni outré, ni affecté; ce qui plaît à nos sens; ce qui séduit notre coeur; ce qui nous intéresse; ce en quoi nous ne trouvons rien qui nous choque, rien qui nous révolte; ce que les fameux Artistes ont le plus universellement pratiqué; ce que les vrais connoisseurs estiment. Tout ce qui n'a pas ces qualités ne peut être que de mauvais goût. (Bollioud-Mermet, 1746, p.48)

[Você me perguntará: mas o que é esse gosto? Quais são alguns dos sinais para distingui-lo? Responderei, sem tentar dar uma definição curta e exata de bom gosto em todo gênero. Penso, a respeito das artes e da música, que o bom gosto é o que está conforme à natureza, que é aprovado pela razão, que não é nem exagerado nem afetado, que agrada aos nossos sentidos, que seduz nosso coração, que nos interessa, aquele que não tem nada que nos choque, que nos revolte, aquele que os artistas famosos mais universalmente praticam, que os verdadeiros conhecedores estimam. Tudo o que não tem essas qualidades só pode ser de mau gosto.] (Tradução nossa)

Além da reflexão de Bollioud-Mermet sobre o fato de o gosto não estar mais de acordo com a imitação da natureza na composição e na execução da música, de os modelos não serem mais imitados de acordo com as regras e normas que valorizavam a linguagem verbal 
das óperas, que se reportassem ao aspecto literário, de acordo com o teatro clássico do século XVII e da tragédia clássica da Antiguidade, ele manifestou sua estranheza com relação ao fato de os artistas fazerem suas obras sem se reportarem a esses modelos, cujas ideias novas vinham, segundo ele, do próprio gênio de quem as produzia. Ele se justificou dizendo que estava de acordo com os partidários do novo, pois assim se evitava a cópia e o plágio, porém ressaltou que, mesmo assim, essas inovações deveriam estar de acordo com as leis da natureza e do bom gosto. Isso demonstrou que as concepções imitativas mostravam-se cada vez menos evidentes na produção das óperas, o que era condenado por aqueles que não concordavam com as produções feitas pela própria criatividade do artista, sem o escopo da tradição:

J'accorde aux Partisans du neuf, qu'il faut que l'Artiste mette de son génie, de son invention dans ses opérations; qu'il évite d'être copiste et plagiaire; qu'il crée de son propre fond des idées nouvelles, des tours de Chants singuliers: mais ce n'est qu'aux conditions que ces idées, ces tours de Chants, ces inventions seront subordonnées aux loix de la nature, et conformes au bon Goût. (Bollioud-Mermet, 1746, p.50)

[Concordo com os partidários do novo: os artistas devem colocar seu gênio, sua criatividade em suas operações, devem evitar ser copistas e plagiadores, devem creditar a seu próprio fundamento as ideias novas, os contornos singulares de seus cantos, mas isso sob a condição de que essas ideias, relativas aos contornos dos cantos, que essas invenções sejam subordinadas às leis da natureza, e conformes ao bom gosto.] (Tradução nossa)

E, apesar de dizer-se a favor dos partidários do novo, considerava que esses colocavam-se contra a verdade, que os conhecedores deveriam opor-se às inovações consideradas abusivas, que as academias de arte e de música deveriam proteger a tradição e o patrimônio que preservassem o bom gosto: 
Il est donc convenable d'opposer des digues à ce torrent. C'est aux habiles Connoisseurs d'élever leurs Voix contre des coutumes abusives: C'est aux Académies de protéger les efforts des Partisans du bon Goût; et à tout homme capable de sentiment, de se déclarer hardiment pour la vérité. (Bollioud-Mermet, 1746, p.53).

[É conveniente, portanto, opor diques a essas torrentes. Cabe aos hábeis conhecedores elevar suas vozes contra os costumes abusivos, cabe às academias proteger os esforços dos partidários do bom gosto, e a todo homem suscetível de sentimento cabe se declarar intrepidamente a favor da verdade.] (Tradução nossa)

Na metade do século XVIII francês, a esfera do sentimento foi se desenvolvendo e dominando o julgamento estético na ópera. A perspectiva do gosto foi se fazendo mais no sentir, em detrimento da razão. E o discernimento do julgamento da música pela inteligência foi ficando em segundo plano na sociedade francesa. Os frequentadores da Ópera, cada vez menos conhecedores da cultura tradicional, devido à ascensão da classe burguesa, contentavam-se cada vez mais apenas com os aspectos agradáveis das óperas e eram ávidos por música "estrangeira", como revelava a incidência de música italiana na ópera francesa.

Os aspectos pessoais do compositor e do executante, como visto no último fragmento de texto de Bollioud-Mermet, ao interferirem e fazerem parte da composição musical, demonstravam que os compositores aos poucos deixaram de preocupar-se em fazer cumprir as regras estabelecidas pela teoria imitativa da natureza, em fazer que, pela representação dos modelos copiados, estes fossem reconhecidos pela audiência.

Outros interesses estavam em jogo nesse momento, na cultura francesa, como a criação de métodos de canto para aperfeiçoar essa arte e a melhoria dos instrumentos musicais - o aumento da dificuldade técnica exigiu a elaboração de métodos de aprendizagem e a aquisição de mais instrumentos musicais. Isso demonstrou 
que não apenas a ópera e a música vocal interessavam à sociedade, mas também a música instrumental, mesmo porque a classe social emergente queria aprender música, e os instrumentos musicais eram uma via para isso. $\mathrm{O}$ interesse se voltava mais para a música em si, sem o vínculo estrito com as regras das teorias imitativas e a ideia de uma representação teatral que tivesse como base o texto poético literário.

Outro grupo de fragmentos de textos que analisamos foi o de Charles Henri de Blainville (1711-1769), compositor que escreveu pequeno número de peças instrumentais, além de peças vocais, mas que não obteve muito sucesso na sua época. Ele produziu algumas obras teóricas sobre música, como L'Esprit de l'art musical [O espírito da arte musical], de 1754, o qual analisaremos a seguir.

Esse artigo foi escrito depois do episódio das Querelas dos Bufões (1752-1753) e nele há ataques à Carta à música francesa (1753), de Jean-Jacques Rousseau (1712-1778). Blainville falou das apresentações de intermezzi italianos (ópera bufa) na ópera francesa, frequentes na época, e fez considerações sobre a língua italiana e a francesa, realçando as qualidades da última, do quanto era melhor para a música vocal do que a outra, além de tecer considerações sobre o gosto e a imitação da natureza.

Também partidário da tradição clássica, Blainville defendeu os franceses e atacou a língua italiana, tida por Rousseau como mais adequada ao canto. Declarou não ter sentido uma nação como a francesa ser considerada não possuidora de uma língua adequada para o canto, pois reconhecia-se que o seu teatro dramático possuía a mais bela escola de declamação em toda a Europa.

Na seção Da voz, no espírito da arte musical, ele fez as seguintes considerações:

Une Nation dont le Théâtre Drammatique seroit reconnu de toute l'Europe comme l'école de la belle déclamation, ne pourroit qu'avoir une langue propre au chant musical. Les François peuvent donc avoir une Musique, à moins que, par une maladie singuliere, 
il ne nous arrivât de devenir sourds et muets; je n'y vois pas d'autre empêchement.

En vain on nous vantera les avantages de la Langue Italienne: s'il n'est question que d'en venir aux comparaisons, cette Langue n'a-t'elle pas des o qui valent bien nos e muets? Qu'est-ce que c'est que leurs u, le z, gn, ci, et cetera toutes prononciations qu'un François ne pourroit acquérir, que par un exercice aussi pénible que ridicule? (Blainville, 1754, p.2-3)

[Uma nação cujo teatro dramático seria reconhecido em toda a Europa como a escola da bela declamação só poderia ter uma língua própria ao canto musical.

Os franceses podem, portanto, ter uma música. A menos que, por alguma doença singular, eles chegassem a se tornar surdos e mudos, não vejo outro impedimento.

Em vão nos servem as vantagens da língua italiana: se é questão de comparação, essa língua não faz bem valer o nosso mutismo? $\mathrm{O}$ que são seus "u”, " $z$ ", "gn", "ci” etc., e todas as pronúncias que um francês não poderia aprender, a não ser por um exercício tão penoso quanto ridículo?] (Tradução nossa)

A referência, como nos outros autores tratados, voltou-se para um gosto refinado francês e para a imitação da natureza, mas, como a discussão sobre a língua apropriada para a ópera estava em voga, o autor elogiou as vozes da nação francesa, que considerava adequadas a todos os gêneros. Mais do que isso, declarou que a beleza estava em manter o gosto, ou seja, em seguir as regras das teorias imitativas em relação à natureza, já que a língua italiana, segundo o autor, tinha na imaginação algo mais do que suficiente para compor música sem precisar de regras, além do uso excessivo da extensão vocal.

Blainville (1754), ao tratar a língua francesa e a italiana, escreveu:

Chaque Langue a ses inconvéniens; l'imagination sembleroit suffire pour composer de la Musique Italienne: mais pour en com- 
poser de la Françoise, il faut y joindre un goût exquis. Préventions à part de la Langue, on ne peut disputer à la Nation Françoise d'avoir de très-belles voix en tous genres, au moins en ce qui regarde les voix naturelles; car pour les voix factices, nous ne les adoptons pas sur nos Théâtres. Ces sortes de voix ont leurs beautés; mais ce ne sont jamais que des singes de la belle nature; et pour peu qu'on oublie l'illusion de trois ou quatre octaves, et de tous leurs tours de passe-passe, on ne s'accommode pas aisément d'un son de fausset dans le haut, de gorge dans le médion, et de creux de la poitrine dans le bas; non plus que de leurs cadences, qui ne sont, à le bien prendre, qu'un chevrottement precipite. (p.3-4)

[Cada língua tem seus inconvenientes. A imaginação pareceria suficiente para a música italiana, mas, para a francesa, deve-se aliar a ela um gosto requintado. Considerações à parte sobre a língua, não se pode atribuir à nação francesa ter as mais belas vozes em todos os gêneros, pelo menos no que diz respeito às vozes naturais, pois as vozes não naturais, nós não as adotamos em nossos teatros. Esses tipos de vozes têm sua beleza, mas jamais possuem os recursos da bela natureza. E, mesmo que esqueçamos a ilusão de três ou quatro oitavas, e todas as suas manobras de ilusionismo, que não se adequem com facilidade a um som de falsete no agudo no meio da garganta, e no peito vazio no grave, que não são mais do que cadências, quando bem realizadas, de um trêmulo precipitado.] (Tradução nossa)

No seu texto, Blainville mencionou a ideia de uma origem da música, que também apareceu nos textos de Dubos e Batteux, advinda do canto, o qual seria usado em rituais e festins, e por isso mesmo seria considerado superior em música, por inspirar o uso das palavras para expressar as paixões humanas. Para os autores mencionados, a harmonia e o ritmo compunham a música, além das palavras, ideia que foi retomada também por Blainville. Pela perspectiva da imitação como sentimento, ela foi, segundo o autor, 
o primeiro sentimento que inspirou os homens. O caráter inicial era o da natureza, a qual por isso mesmo deveria ser imitada, fosse na música vocal ou na instrumental, nesta com a utilização da imitação de ruídos para a sua composição.

Sobre a origem da música e do gênero cantabile, o autor escreveu:

Ce genre, ou le chant proprement dit, est le premier cri de la nature, c'est la souche de tout l'art Musical. L'homme chante même en parlant, de-là naît la Musique. Les Pastres, nos premiers peres, vouloient danser; ils prirent une flute, un chalumeau, ils jouerent des airs.

Dans leurs nôces, dans leurs festins, dans les sacrifices, ils penserent à animer les paroles consacrées à leurs Fêtes; et ils chanterent, inspirés par le seul instinct. Le chant est donc le genre supérieur en Musique, puisque c'est le premier sentiment dont les hommes ont été inspirés, et auquel la Musique doit son origine.

Ce genre ajoute à la parole, anime les mouvemens des passions, soit de joie ou de tristesse, de crainte ou de fureur, et cetera. Il sert encore à exprimer les images de ce qui se passe au dehors de nous, comme ramages d'oiseaux, tempête, bruit de guerre, et cetera. En un mot, le chant dont le caractere est pris dans la nature, est le coup de pinçeau qui exprime toutes ces diverses choses.

L'art de ce genre consiste à sçavoir employer avec une valeur mesurée, les différens intervalles de tierce, quarte, quinte, et de tons et de demi-tons, et d'en former une suite de modulations ou modes propres à la passion, ou peinture qu'on s'est proposé? Art qu'on ne peut enseigner, et qui s'exprime, selon qu'il est plus ou moins gravé dans l'esprit du Compositeur; il en est de la Musique comme de la Poësie: en vain donnera-t'on des regles, si l'on n'est inspiré par le génie. (Blainville, 1754, p.12-4)

[Esse gênero, ou o canto propriamente dito, é o primeiro brado da natureza, é a estirpe de toda a arte musical. O homem canta mesmo falando, desde o surgimento da música. Os pastores, nos- 
sos primeiros pais, desejaram dançar, tomaram uma flauta, um chalumeau, ${ }^{18}$ e tocaram árias.

Em suas núpcias, em seus festins, nos sacrifícios, para animar as palavras consagradas em suas festas, cantaram inspirados pelo único instinto. $\mathrm{O}$ canto é, portanto, o gênero superior em música, uma vez que é o primeiro sentimento, portanto, em que os homens se inspiraram e ao qual a música deve sua origem.

Esse gênero se juntou à palavra, animada pelo movimento das paixões, seja a alegria ou a tristeza, seja o medo ou o furor etc. Ele ainda a usou para exprimir as imagens que existem ao redor de nós, como o arrulhar dos pássaros, a tempestade, o ruído da guerra etc. Em uma palavra, o canto, cujo caráter é o primeiro na natureza, é a pincelada que exprime todas essas coisas.

A arte desse gênero consiste em saber empregar, com um valor mensurado, os diferentes intervalos de terça, quarta, quinta, de tons e de meios-tons, e de formar um conjunto de modulações ou modos próprios à paixão, ou à pintura a que se propõe? A arte pode nos ensinar um pouco, e se expressa segundo aquilo que é mais ou menos gravado no espírito do compositor. A música é como a poesia: em vão dar-lhe regras se não é inspirada pelo talento.] (Tradução nossa)

Para Blainville, assim como o canto foi a primeira manifestação da humanidade através da natureza, daí surgiram as árias francesas, simples e fruto do cantabile, tal qual a natureza, e apenas ditadas pelo gosto. Assim, eram algo para poucos, ou seja, apenas para os conhecedores que conhecessem a sua origem e os modelos dos quais haviam sido copiadas.

Mesmo sem a melodia, o texto da ária, simplesmente declamado, já era por si só uma fonte de prazer e deleite:

18 Instrumento de palheta única e tubo predominantemente cilíndrico, relacionado ao clarinete. Surgiu no final do século XVII e foi construído em vários tamanhos. No final do século XVIII, a palavra começou a ser empregada significando o registro mais grave do clarinete (cf. Sadie, 1994, p.185). 
Le caractere du chant François tient particulierement au Cantabile qu'on examine. Nos chants se saisissent, se retiennent aisément [-16-] par coeur; nos plus beaux Monologues s'entendent même avec plaisir, quoique sans accompagnement. Il en est autrement des morceaux Italiens qui ne se montrent que parés de tous leurs atours, dont les beautés échappent à l'instant comme une flamme subtile; on diroit que c'est un langage fait pour les Dieux, qu'il n'est permis qu'à un petit nombre d'entendre. A l'égard des chants réservés pour notre société, pour nos plaisirs, nous les savourons avec délices; leur simplicité fait l'amusement des adeptes, comme des initiés. En effet, quel nombre d'airs, tous plus beaux les uns que les autres, qui ne tirent leur mérite que du Cantabile! La nature enfante ces airs, l'imagination y prend peu de part, mais le goût [-17-] seul les dicte. Quel mérite dans ces productions du seul génie! combien un jour à venir ces étincelles seront précieuses, lorsque le sein avare de la nature ne donnera plus de ces hommes, dont le coeur est la source où ils puisent leurs pensées, d'autant plus belles, qu'il n'appartient pas toujours à l'homme le plus éclairé de les produire, mais à l'homme de plus de goût. (Blainville, 1754, p.15-7)

[O caráter do canto francês consiste particularmente no cantabile, que passo a examinar. Nossos cantos se submetem, são retidos facilmente pelo coração. Nossos mais belos monólogos são até mesmo ouvidos com prazer, embora sem acompanhamento. Diferente das peças italianas que ostentam toda elegância, das quais as belezas escapam em um instante, como uma chama sutil, seria dizer que é uma linguagem feita pelos deuses, a qual permite a um pequeno número que seja ouvida. No que se refere aos cantos reservados para a nossa sociedade, para o nosso prazer, nós os saboreamos como delícias. Sua simplicidade diverte os seus adeptos, como os iniciados. Com efeito, qualquer ária, umas mais belas do que as outras, retira seu mérito do cantabile! A natureza gera essas árias, a imaginação assume uma parte delas, mas somente o gosto as dita! 
Que mérito o dessas produções únicas do gênio! Virá um dia em que essas centelhas serão preciosas, quando o seio avaro da natureza deixar esses homens, cujo coração é a fonte da qual extraem seus pensamentos os mais belos, que nem sempre pertencem ao homem o mais iluminado para produzi-los, mas ao homem de mais gosto.] (Tradução nossa)

O autor observou que os intermezzi italianos revelavam o gosto da sua nação e que de fato eles encantaram os franceses, mas poucas coisas deles podiam ser aproveitadas, dada a sua simplicidade, característica cara aos franceses.

Les Intermedes Italiens ont des morceaux qui nous ont charmé, ce qui prouve le bon goût de la Nation; mais cet aveu nous met entre un précipice et une prairie bordée de fleurs. Entre notre genre, le genre Italien, [...], il y a des nuances qui pourroient échapper, même aux plus habiles Artistes; voilà le précipice. Notre genre est simple, naif, ferme et vigoureux; le genre Italien a des beautés d'expression, des finesses d'agrément que nous pouvons acquérir, voilà les fleurs; c'est à nous de les cueillir, sans perdre de vue que nous sommes François. (Blainville, 1754, p.18-9)

[Os intermédios ${ }^{19}$ italianos são as peças que mais nos encantam, o que prova o bom gosto da nação, mas este fato nos coloca entre um precipício e uma pradaria repleta de flores. Entre o nosso gênero e o gênero italiano [...] existem nuanças que poderiam escapar até mesmo aos mais hábeis artistas, eis o precipício. Nosso gênero é

19 Música e dança inseridas entre os atos de um espetáculo mais amplo; a contrapartida francesa do italiano intermedio ou intermezzo. Sua história remonta a meados do século XVI. No final do século XVII, os intermèdes podiam ser composições extensas, independentes, comparáveis a uma ópera completa. Um intermède não se relacionava necessariamente com a obra em que era inserido. Os de Lully e Charpentier para as comédias de Molière representam o apogeu do gênero (cf. Sadie, 1994, p.459). 
simples, ingênuo, firme e vigoroso. O gênero italiano tem as belezas da expressão, as sutilezas da ornamentação, que nós podemos aproveitar. Aqui as flores, as quais cabe a nós escolher sem perder de vista que somos franceses.] (Tradução nossa)

Assim como Dubos e Batteux, que assinalaram o papel da harmonia e do acompanhamento, Blainville também deu-lhes destaque, ao declarar que realçavam o caráter do canto, ampliando a expressividade das palavras, e que a escolha das notas e dos intervalos permitia expressar as belezas dos sentimentos, embora no quesito instrumental admitisse que os italianos eram melhores do que os franceses:

La Melodie est à la Musique, ce que les pensées sont aux discours; c'est pour mieux dire le Cantabile; ce qui dépend, comme j'ai dit ci-devant, du choix des notes et des intervalles, moyen par lequel on peint dans une seule partie les plus grandes beautés de sentiment ou d'image.

On ajoute à cette expression par les accompagnemens qui font harmonie. Ces parties doivent faire entr'elles unité de melodie, car en soi l'harmonie n'est rien, si elle ne concourt à l'effet; c'est la couleur qui donne l'ame au dessein, ou qui le gâte si elle est mal employée. L'unité de mélodie consiste donc en ce que le chant des accompagnemens soit d'un caractere propre et conforme au sujet principal, c'est-à-dire dans la même modulation, le même caractere et la même mesure, qu'il le suive pas à pas. Il faut que ces notes écoutent, considerent, répondent; enfin le chant est acteur, et l accompagnement pantomime: tantôt il s'emporte, ou bien il est tranquille, il écoute, il regarde, il est immobile. Il s'anime des yeux et du geste, toujours conforme à son acteur qu'il ne perd point de vue. Il annonce, il soutient, il prend les vuides, il termine; enfin il fait dans son genre ce que le chanteur fait dans le sien, il peint en symphonie ce que l'autre peint en chant. Il faut avouer qu'à ce sujet les Italiens nous sont fort supérieurs; voyons comment nous en approchons. (Blainville, 1754, p.22-4) 
[A melodia é para a música aquilo que os pensamentos são para o discurso. Isto é, o cantabile, melhor dizendo, depende, como disse até aqui, da escolha das notas e dos intervalos, meio pelo qual se pinta apenas parte das maiores belezas do sentimento ou da imagem.

Essa expressão é complementada pelos acompanhamentos que fazem a harmonia. Essas partes devem construir a unidade da melodia, porque a harmonia em si não é nada se não concorre para o efeito. É a cor que dá alma ao desenho, ou que o estraga se mal empregada. A unidade da melodia implica, portanto, que o acompanhamento do canto tenha um caráter próprio e conforme ao tema principal, isto é, a mesma modulação, o mesmo caráter e a mesma medida, que ele os siga passo a passo. Devem-se ouvir essas notas, considerá-las, fazer que correspondam. Enfim, o canto é o ator, e o acompanhamento, a pantomima. Às vezes ele prevalece, ou fica bem tranquilo; às vezes escuta, observa, ou fica imóvel. Ele anima os olhos e o gesto, sempre conforme o seu ator, quando não o perde de vista. Ele anuncia, sustenta, prende aos olhos e termina. Enfim, ele faz de seu gênero aquilo que o cantor faz de si, pinta em sinfonia aquilo que a outra pinta em canto. Deve-se admitir que nesse tema os italianos são bastante superiores a nós. Vejamos como nos aproximamos deles.] (Tradução nossa)

Dentre as polêmicas da época, estavam as querelas, que serão discutidas no próximo capítulo, que atacaram a opera seria francesa e também Jean-Philippe Rameau (1683-1764). Ao falar do acompanhamento, Blainville expressou que aprovava o seu sistema de harmonia, como deixa evidente neste fragmento de texto:

Cet accompagnement consiste dans un chant suivi de deux, trois, ou même quatre croches ou noires d'un caractere dinstinct et continu. Ce genre s'employe lorsqu'il s'agit de quelque grande passion, ou de quelque forte peinture prise dans la nature. Ces accompagnemens doivent faire le personnage dont j'ai parlé ci-devant, c'est-à-dire, ajouter à l'expression du chant. Monsieur Rameau en a rencontré de très-heureux en ce genre: mais en général, nos accompagnemens sont au plus simple, sans un caractere 
absolument marqué. Leur effet est velouté, moëlleux, satisfaisant; mais ils ne percent pas avec ces traits de feu qui se répandent en éclats, qui ravissent, transportent l'auditeur hors de lui-même. Aussi il faut avouer que les Italiens sont fort au-dessus de nous en ce genre, et c'est là même où consiste le sublime de leur Musique. Ils ont en ce genre des morceaux si supérieurs, qu'on oublie que ce sont des beautés musicales; l'illusion est forte au point qu'on croit que c'est la chose même que l'on voit, que c'est là qu'on existe. Un feu se répand dans les veines, on se sent soulever; l'imagination en désordre, le coeur ému, on est transporté comme dans un autre hémisphere: voilà de ces situations que les personnes sensibles à l'attrait Musical ont éprouvé avec un ravissement dont on n'a à se plaindre que du peu de durée. (Blainville, 1754, p.30-1)

[Este acompanhamento consiste em um canto seguido de duas, três ou mesmo quatro colcheias ou semínimas de caráter distinto e contínuo. Este gênero se emprega quando se trata de uma grande paixão, ou de alguma expressiva pintura retirada da natureza. Esses acompanhamentos devem fazer a personagem, como já disse anteriormente, juntar a expressão com o canto. O senhor Rameau as encontra de maneira muito feliz neste gênero, mas em geral nossos acompanhamentos são muito mais simples, sem um caráter absolutamente marcado. Seu efeito é aveludado, confortável, satisfatório, mas eles não perfuram com estes traços de fogo que se propagam em claridades, que deleitam, transportam o auditório para fora de si mesmo. Assim, deve-se admitir que os italianos estão fortemente acima de nós nesse gênero, e é aí mesmo que se encontra o sublime de sua música. Eles têm nesse gênero as melhores peças, a ponto de esquecermos que são belezas musicais. A ilusão é forte, ao ponto de acreditarmos que é a coisa mesma que vemos, que está onde estamos. Um fogo se espalha pelas veias e o sentimos se elevar. A imaginação em desordem, o coração emocionado, como se transportado para outro hemisfério. Apresentamos essas situações em que as pessoas sensíveis atraem a música e experimentam, com arrebatamento, aquilo de que se queixam pela pouca duração.] (Tradução nossa) 
Ele era conhecedor da ópera bufa, assim como das disputas da época, como podemos inferir do seguinte texto. Ao questionar quais eram as disputas na ópera italiana, tomou partido: para ele, sem dúvida, a melhor música era a francesa.

Alors on commença à s'appercevoir de toutes les richesses musicales. Les Bouffons ont achevé de tirer le rideau, et de nous convaincre de cette vérité par les charmes de leurs intermedes. Mais, quelles disputes? quels discours sans rien conclure? Sans doute que nous prendrons le parti opposé de n'en mot dire, et de les étudier en secret; et il est à présumer que ces beautés nous plairont davantage, lorsqu'un jour nous les verrons habillées à la Françoise. (Blainville, 1754, p.36)

[Então começamos a perceber todas as riquezas musicais. Os bufões acabaram de abrir a cortina, e nos convencemos dessa variedade pelos encantos de seus intermezzi. Mas quais são as disputas? Quais são os discursos que nada concluem? Sem dúvida, tomamos a parte oposta de qualquer palavra e a estudamos em segredo, e presume-se que essas belezas nos agradariam mais quando um dia os vermos vestidos à francesa.] (Tradução nossa)

Quanto ao estilo, Blainville reforçava a clareza e a simplicidade da música francesa em relação à italiana. Comparada à pintura, expunha como num quadro em que tudo era perceptível e reconhecido, sendo o gosto orientado pela razão. Sempre em comparação com os italianos, tinha nestes como o oposto de tudo isso, com exageros e falta de gosto:

Les graces du goût, un tact aisé, délicat, un discernement vaste, étendu, ordonnent toutes ces choses avec une oeconomie, si l'on peut dire, admirable. Les détails pris séparément ne sont pas d'un feu, d'un éclat hardi, éblouissant; mais le tout ensemble fait un tableau de goût, dont la raison fait la principale ordonnance; genre auquel la Musique Italienne est totalement opposée. Les détails en sont admirables, inimitables, si l'on veut; mais de la variété, de l'ordonnance, de la distribution, n'en cherchez aucune. (Blainville, 1754, p.44) 
[As graças do gosto, um tato fácil, delicado, um discernimento vasto, expandido, ordenando todas essas coisas com uma economia, se assim se pode dizer, admirável. Os detalhes tomados em separado não são de um fogo de uma claridade ousada, deslumbrante, mas todo o conjunto compõe um quadro do gosto em que a razão faz a ordenação principal, gênero ao qual a música italiana é totalmente oposta. Os detalhes em si são admiráveis, inimitáveis, se quisermos, mas a variedade, a ordenação da distribuição não são procuradas.] (Tradução nossa)

O autor considerava a língua francesa um exemplo de gosto e requinte naturais, próprios do caráter nacional francês, ordenado e condutor do gosto mais refinado e subserviente à razão. Afirmou ser natural na língua italiana uma desordem da imaginação, o que transparecia na sua ópera, desordem que estava distante da língua francesa, cujos sentimentos eram nobres e circunspectos, condizentes com as próprias paixões humanas:

Toutes ces différences ne viennent que du caractere de la Nation, ou plutôt de la Langue, et de ce que telles ou telles idées sont plus naturelles à l'une qu'à l'autre, ainsi que de la différence des longues et des bréves. En effet dans la Langue Italienne les longues et les bréves ont leur mesure déterminée, ou plutôt ce sont tous monosyllabes égaux, qui se prêtent également à l'imagination du Poëte et du Musicien. Au contraire dans la Langue Françoise, les longues et les bréves sont tellement d'obligation, que loin que le Poëte et le Musicien puissent s'abandonner à tous les désordres de l'imagination, toujours en garde contre eux-mêmes, ils ne se laissent conduire que par le goût le plus épuré et la plus saine raison. La Poësie Italienne, vive et piquante, est propre aux images, aux divers phénomènes qui se passent hors de nous; au contraire la Langue Françoise, sage, noble et circonspecte, ne se plaît particulierement qu'aux sentimens de nos passions, aux affections, aux mouvemens qui se passent en nous; enfin, le style des Italiens est grand, en ce qu'il est concis et serré; et le nôtre est beau, en ce qu'il est diffus et étendu. On peut comparer le premier, à cause de la violence, de la 
rapidité et de la véhémence avec laquelle il ravage, pour ainsi dire, et emporte tout, à une tempête, à un foudre. (Blainville, 1754, p.44-6)

[Todas essas diferenças vêm do caráter da nação, ou melhor, da língua, e algumas ideias são mais naturais a uma do que à outra, ainda que exista diferença entre as longas e as breves. Com efeito, na língua italiana, as longas e as breves têm sua medida determinada, ou melhor, ela tem todos os seus monossílabos iguais, que se prestam igualmente à imaginação do poeta e do músico. Ao contrário, na língua francesa, as longas e as breves são assim obrigadas, na medida em que o poeta e o músico possam se abandonar a todas as desordens da imaginação, sempre em guarda contra eles mesmos, deixando-se conduzir pelo gosto o mais apurado e a mais sã razão. A poesia italiana, viva e picante, é própria às imagens, aos diversos fenômenos que se passam fora de nós. Ao contrário, a língua francesa, sagaz, nobre e circunspecta, agrada particularmente aos sentimentos de nossas paixões, às afeições, aos movimentos que se passam em nós. Enfim, o estilo dos italianos é grande naquilo em que é conciso e cerrado, e o nosso é belo naquilo em que é difuso e expandido. Podemos comparar o primeiro à causa da violência, à rapidez e à veemência com a qual devasta, por assim dizer, e leva tudo a uma tempestade, a um relâmpago.] (Tradução nossa)

Dado que Rousseau tivesse tomado o partido da língua italiana e atacado a francesa, assim como a ópera e Rameau, Blainville, ao tomar o partido da opera seria francesa, fez referência à composição de Rousseau, $O$ adivinho da aldeia, e do quanto, em sua concepção, essa obra estava distante das regras que considerava condizentes com a composição musical. Ao referir-se a Lully como exemplo de compositor, trouxe mais uma vez à tona a importância da tradição e daqueles que souberam usar os temas nobres em suas composições:

Monsieur Rousseau a beau dire, il a fait du chant François, sans le vouloir; mais pour quelques endroits de cette nature, combien de passages, sur-tout dans le rôle du Devin, d'une modulation peu flexible, qui met également l'auditeur et l'acteur dans les entraves, 
et cela pour avoir voulu sortir du genre propre à la Langue. On doit néanmoins lui savoir gré de nous avoir donné le premier à connoître qu'on pouvoit trouver des tours simples, et voisins de la nature dans le genre familier. Je les crois cependant plus difficiles à saisir dans le genre héroïque. Lully a bien commencé, et ce n'est qu'en l'étudiant qu'on peut parvenir à mieux faire. (Blainville, 1754, p.53-4)

[O senhor Rousseau bem disse, ao realizar o canto francês, sem o desejar, mas em algum lugar desta natureza, quanto às suas passagens, sobretudo no papel do Adivinho da Aldeia [Devin du Village $],{ }^{20}$ uma modulação pouco flexível, que coloca igualmente a audiência e o ator nos entraves, e isso por desejar sair do gênero próprio da língua. Devemos, contudo, ser gratos ao seu saber, por nos fazer ser os primeiros a conhecer e poder encontrar seus truques simples e avizinhar-nos da natureza no gênero familiar. Creio, no entanto, que é mais difícil de conhecer no gênero heroico. Lully começou bem, é nisso que o estudante pode conseguir fazer melhor.] (Tradução nossa)

Dentre os diversos aspectos observados, sobre os quais refletiu em seu texto, Blainville também se referiu à questão da expressão em música. Para ele, expressar significava demonstrar a verdade do que lhe era próprio, mas de forma agradável e nobre. A introdução de elementos da ópera italiana na ópera francesa não só destruía as regras imitativas de modelos da natureza, conforme a concepção da época, mas também uma concepção de gosto, o que significava destruir a concepção da ideia de um caráter nacional, ${ }^{21}$ elemento tão caro à sociedade francesa:

20 O Devin du Village [O Adivinho da Aldeia] foi um intermédio escrito por Jean-Jacques Rousseau, apresentado pela primeira vez em 18 de outubro de 1752.

21 A ideia de um caráter nacional francês, cujos traços deveriam ser reconhecidos por todos aqueles que conheciam a nação, era algo extremamente importante para essa sociedade, incomodada com a presença de elementos estrangeiros, como acontecia com a ópera italiana. Em seu artigo, Blainville (1754) assim se manifestou: "Gostaríamos de ter uma música italiana feita com palavras francesas? E uma música francesa feita com palavras italianas? Pessoalmente, 
Il y a plusieurs especes d'expression en musique; il y a expression vocale et instrumentale, et expression où toutes les deux se trouvent réunies.

Comme l'expression ne dépend pas seulement du caractere du sujet, mais encore de sa destination, le Compositeur doit avoir attention qu'il y a un local pour l'expression; et que, tel beau que puisse être un morceau, s'il manque par la convenance, c'est manquer comme à l'expression. (Blainville, 1754, p.71-2)

[Há várias espécies de expressão em música. Há a expressão vocal e a instrumental, e a expressão em que as duas se encontram reunidas.

Como a expressão não depende unicamente do caráter do tema, mas também de sua destinação, o compositor precisa prestar atenção se existe um local para a expressão. E, por mais bela que possa ser uma peça, se lhe falta conveniência, falta-lhe expressão.] (Tradução nossa)

Ainda sobre a importância da expressão em música, o autor escreveu:

L'Expression doit être l'ame de ce genre de musique, plus que de tout autre; il seroit même à souhaiter quelle s'y trouva au point que l'art n'y parût que comme un vernis pour bien joindre les pieces de rapport qui font le total de l'ouvrage; de façon que cet art apperçu seulement des Artistes, l'auditeur, sans en être distrait, ne fut intéressé que par les seules beautés du génie.

Il y a dans un Opéra, des morceaux d'expression, d'autres de sentiment, ceux là pour l'effet. (Blainville, 1754, p.74)

não imagino tal metamorfose. Precisamos de uma música natural, tal como nossa língua e nosso caráter nos sugerem. Todos os povos da Europa, diremos, concordam quanto à presença da música italiana. Em boa hora eles se sentem assim (concordando com a presença da música italiana), e nós, diferentemente deles (porque não aceitamos sua língua e sua música), é porque sua língua não se presta ao acento musical” (p.124, tradução nossa). 
[A expressão deve ser a alma desse gênero de música, mais do que qualquer outro. Seria o mesmo como o que se encontra lá, a tal ponto que a arte parece um verniz para bem juntar as peças que são produto de um total de obras. Que esta arte perceba unicamente aos artistas, ao auditório, sem se distrair, interessada nas únicas belezas do gênio.

Há numa ópera peças de expressão, outras de sentimento, e aquelas para o efeito.] (Tradução nossa)

O autor categorizou os segmentos da expressão em música. Cada um deles, segundo as regras, deveria possuir primeiramente a concepção de um texto literário que servisse ao monólogo, à declamação, valorizando os aspectos racionais da língua e as características pertinentes a cada tipo de afeto manifestado no texto. Através do texto literário, depreendiam-se os caracteres de cada expressão afetiva; a partir de cada expressão, construía-se a melodia e o acompanhamento que lhe eram pertinentes.

A força da tradição clássica teatral, junto com a pintura, na formação de um quadro dos sentimentos, era bastante incentivada pelos seus partidários:

Les morceaux de sentimens, sont les Scenes galantes, tendres et pathétiques, les Scenes où l'amour, l'amitié et la générosité se font un mutuel combat. Les Scenes opposées, sont les Scenes fortes, vives et animées, où les sentimens de crainte, de dépit, d'artifice, de jalousie, de parjure, se peignent sous les traits les plus noirs. Voilà les morceaux, les Scenes d'intérêts, où la Langue doit être traitée plutôt en pure déclamation, qu'en chant; de façon que l'acteur n'étant pas contraint par un chant trop musical, aye toute la liberté de donner plus de force au récit, tant par les inflexions du chant, que par l'expression du geste. De ces Scenes d'intérêts, naissent les morceaux d'expression, tels que les Monologues, les Duo, les morceaux animés par les passions décidées de joie ou de douleur, de haine ou d'amour, et cetera. Passions qui doivent se peindre avec toute la force, la hardiesse, et la beauté de l'expression du chant musical. 
C'est alors que l'instrumentale, jointe à la vocale, préte à celle-ci de nouvelles forces. Le prélude annonce le caractere de l'air, et prépare également l'auditeur et l'acteur à entrer dans la passion. Les endroits de silence qui se trouvent dans le chant, en répandant de la variété par les traits de l'instrumentale, que n'auroit pu faire la vocale, donnent en même-tems la facilité au chanteur de soutenir son air avec bien plus de vigueur, que s'il falloit qu'il le débite sans aucun repos. (Blainville, 1754, p.74-6)

[As peças de sentimentos são as cenas galantes, ternas e patéticas, as cenas em que o amor, a amizade e a generosidade estão em combate. As cenas opostas são as cenas fortes, vivas e animadas, em que os sentimentos são o medo, o despeito, o artifício, o ciúme, o perjúrio, e se pintam os seus traços os mais negros. Aqui as peças, as cenas de interesse, em que a língua deve ser tratada mais em pura declamação do que um canto, de modo que o ator não seja contrário a um canto demasiado musical. Sim, toda liberdade serve para dar mais força ao recitativo, tanto pelas inflexões do canto como pela expressão do gesto. Das cenas de interesse nascem as peças de expressão, tais como os monólogos, os duetos, as peças animadas pelas paixões da alegria ou da dor, do ódio ou do amor etc. Paixões que devem se pintar com toda a força, a ousadia e a beleza da expressão do canto musical.

Em seguida é fundamental que o instrumental, juntado à vocal, empreenda novas forças. O prelúdio anuncia o caráter da ária e prepara o auditório e o ator a entrar na paixão. Os momentos de silêncio do canto, em contraste com a variedade de traços da música instrumental, são um preparo para a música vocal, e ao mesmo tempo facilitam ao cantor sustentar sua ária com maior vigor, como se fosse uma locução sem nenhuma interrupção.]

A força das regras das teorias imitativas se fazia presente até mesmo nos locais destinados a cada tipo de apresentação. Assim como no teatro da Antiguidade havia lugares próprios para a apresentação de tragédias e outros para a de comédias, o mesmo ocorria no teatro clássico francês do século XVII: cada gênero de ópera tinha seu local apropriado, e os gêneros não se misturavam, o que na ópera italiana era comum: 
L'air de vérité, en Musique, consiste encore dans le local, dans le genre de sa destination; c'est-à-dire, qu'une Musique de Théâtre ne doit point tenir, en général, de la Musique de concert, et encore moins de la Musique d'Eglise, non plus que ces deux dernieres ne doivent tenir de la première. (Blainville, 1754, p.88-9)

[A ária da verdade, em música, consiste ainda no local, no gênero de sua destinação. Uma música de teatro não deve tomar, em geral, nada da música de concerto, e ainda menos da música da igreja, e estas duas últimas não devem ter nada da primeira.] (Tradução nossa)

Blainville chamou a atenção, quanto às regras composicionais e às apresentações das óperas, para o fato de que os gêneros não deveriam se misturar. Na formação e no exercício do gosto, cada segmento deveria usar exclusivamente as características que lhe eram pertinentes. Somente assim cada paixão poderia ser expressa, intensificada, conhecida e reconhecida, de acordo com sua categoria.

Quel goût, pour n'inspirer dans la Musique de Théâtre que les passions les plus fortes, les images les plus vives, des tableaux frappans, et la volupté la plus délicieuse: faire ensorte qu'un Opera soit un, entier; et que les genres qui conviennent à la Tragédie, au Ballet, ou à la Pastorale, se montrent toujours distinctement dans l'un ou dans l'autre, sans que la simplicité de cette derniere emprunte la magnificence de la Tragédie, ou le brillant du Ballet! (Blainville, 1754, p.89-90)

[Que o gosto, por somente inspirar na música de teatro as paixões as mais fortes, as imagens as mais vivas, os quadros os mais fascinantes, e a volúpia a mais deliciosa, faz garantir que uma ópera seja única, inteira. E os gêneros que convêm à tragédia, ao balé, ou à pastorale, que se mostrem sempre distintamente num e noutro, sem que a simplicidade desta última empreste a magnificência da tragédia, ou o brilhantismo do balé!] (Tradução nossa) 
O autor chamou a atenção ainda para o tempo de duração da ópera, que deveria estar de acordo com o tempo exigido na duração da tragédia antiga e clássica, além da ligação entre as suas partes, como ocorria com o texto da tragédia, mantendo as características próprias do gênero no que se referia às personagens elevadas na ação dessa narrativa. Havia a prerrogativa de uma unidade de tempo que deveria ser proporcional para todos os acontecimentos e ações. $\mathrm{O}$ conjunto de todos esses aspectos seria perfeito se houvesse unidade entre eles e harmonia no todo. Blainville ressaltou essa importância na ópera francesa, em comparação com a italiana, que, do seu ponto de vista, mantinha mais atenção na música do que nos outros componentes, havendo assim desequilíbrio entre esses aspectos:

Proportion en Musique, c'est l'art de donner à un morceau (méchanisme à part) la longueur convenable, de façon que le milieu réponde au commencement, à la fin, et qu'il soit varié sans sortir de son genre, ni de son caractere. C'est de cette perfection que dépend sur-tout l'esprit d'unité: art précieux que nous possédons en tous arts généralement. Je craindrois cependant qu'à examiner des morceaux de Musique séparément, il parût que nous n'ayons qu'à force d'art, ce que les Italiens semblent avoir par abondance de génie. (Blainville, 1754, p.90-1)

[Proporção em música é a arte de dar a uma peça (mecanismos à parte) a extensão de tempo conveniente, de maneira que o meio corresponda ao começo e ao fim, e que seja variado, sem se distanciar de seu gênero, nem de seu caráter. Essa é a perfeição, que depende sobretudo do espírito de unidade: arte preciosa que possuímos em todas as artes em geral. Acredito, no entanto, que, ao examinar as peças de música em separado, pareça apenas que temos a força da arte, o que os italianos parecem ter pela abundância de gênio.] (Tradução nossa)

Além de criticar os gêneros específicos na ópera, em comparação com a tragédia grega, Blainville criticou a sociedade que frequen- 
tava a Ópera, a qual também comparou ao que considerava ser a sociedade grega. A sofisticação de cada gênero deveria estar de acordo com o conhecimento do público que saberia apreciar o requinte de cada um deles. Para ele, os particulares que se reuniam para assistir a ópera eram os menos conhecedores, porém eram eles que determinavam como deveriam ser as apresentações, como se uma minoria pudesse decidir quais apresentações e quais das suas qualidades deveriam ser representadas no palco, fazendo assim mais um ataque à ópera italiana e, mais especificamente, a Rousseau:

Les anciens Grecs ne pensoient pas ainsi. Tous les genres étoient distincts, non-seulement par les institutions, par le caractere, mais même encore par l'usage. Tel genre de Musique consacré à l'héroïque, ne descendoit jamais aux amusemens particuliers, non plus que les chansonnettes n'avilissoient pas de leur petitesse la grandeur du chant héroïque. La raison de cette différence est bien simple. Le discernement des Grecs, leur jugement étoit celui de toute la Nation réunie, qui venoit en foule chercher le plaisir dans un esprit d'admiration pour les belles choses, capables de les toucher, ou d'indignation, pour qui avoit le malheur de lui déplaire. Parmi nous, c'est tout l'opposé: ce sont quelques particuliers qui viennent s'assembler à nos Théâtres, avec un esprit d'amusement à peu près le même que dans nos sociétés; le même génie, que les Grecs, nous inspire, même avec un goût plus épuré; mais ce n'est pas avec cette vigueur, cette franchise et cette hardiesse naturelles au génie populaire. (Blainville, 1754, p.104-5)

[Os antigos gregos não pensavam assim. Todos os gêneros eram distintos, não somente pelas instituições, pelo caráter, mas mais ainda pelo uso. Tal gênero de música, consagrado ao heroísmo, não derivou jamais dos divertimentos particulares, nem da pequenez de suas cançonetas aviltadas, a grandeza do canto heroico. A razão dessa diferença é bem simples. O discernimento dos gregos, seu julgamento, foi o de toda a nação reunida, que em conjunto procurara o prazer de um espírito de admiração pelas belas coisas, 
capazes de tocá-la ou indigná-la, e que tiveram a infelicidade de desagradar-lhe. Entre nós, ocorre totalmente o oposto: são apenas alguns particulares que se reúnem a nós nos teatros, com um espírito de divertimento parecido nas nossas sociedades. O mesmo gênio que os gregos nos inspiram, mesmo com um gosto mais apurado, mas não com este vigor, este privilégio e esta ousadia naturais ao gênio popular.] (Tradução nossa)

Blainville criticou ainda mais a influência que os bufões exerceram na música francesa e também a tomada de partido dos filósofos, e não somente dos músicos, com relação a esse gênero musical. Declarou que o mérito das coisas deveria ser julgado já na primeira impressão e que, se assim não fosse, não haveria progresso nas artes. Além disso, para ele, era com as primeiras impressões que se poderia observar a solidez do conhecimento guiado pela luz da razão:

N'a-t'on pas vu passer successivement le goût de Lully à celui de $\mathrm{R}$ ****, et ce dernier s'éclipser pour un moment à la vue des bouffons? Ces genres n'ont-ils pas commencé par essuyer des difficultés? A-t'on distingué d'abord leurs vraies beautés? Me dira-ton à présent qu'il n'est question que de juger du mérite des choses par la premiere impression? Par cette seule opinion, nul progrès dans les arts, au moins quant à certains genres de beautés. Cet instinct, ou pour mieux dire, ces sensations nous tromperoient donc souvent, si elles ne sont guidées par les lumieres de l'esprit, et par des connoissances solides: réflexion qui doit nous garantir de porter nos jugemens avec trop de promptitude. En faveur de nos disputes, je me flatte qu'on voudra bien me passer cette digression. (Blainville, 1754, p.108-9)

[Será que não se viu passar sucessivamente o gosto de Lully

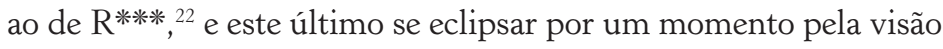
dos bufões? Estes gêneros não começam por trazer dificuldades? Em tom distinto, aborda suas verdadeiras belezas? Ou me dirá

22 Referência a Jean-Jacques Rousseau. 
agora que é uma questão de se julgar o mérito das coisas pela primeira impressão? Por esta opinião, é nulo o progresso nas artes, ao menos no que se refere a certos gêneros de belezas. Este instinto, melhor dizendo, estas sensações muitas vezes nos enganam se não são guiadas pelas luzes do espírito e pelos conhecimentos sólidos. A reflexão deve garantir nossos julgamentos com muita prontidão.

Em favor de nossa disputa, eu me satisfaço em bem transmitir esta digressão.] (Tradução nossa)

Para justificar seu posicionamento em relação à opera seria, o autor afirmou que a ópera deveria interessar aos ouvidos como a pintura interessava aos olhos e que, após a alma ter sido tomada pelas paixões, depois da primeira percepção todos esses sentimentos passariam para a observação das imagens da natureza. O prazer do coração estava em reconhecer nas imagens, como numa pintura, os traços da natureza. A aceitação da música instrumental também foi expressa nesse texto, mas Blainville declarou que a música vocal estava em primeiro lugar, pois era a própria natureza, aquela que melhor expressaria o caráter dos sentimentos, e a instrumental em segundo lugar, pois seria uma débil imitação da natureza, apesar de cumprir sua função na ópera. Ressaltou ainda que a audiência deveria estar preparada para captar essas nuanças e assim se contentar com o máximo possível do requinte reconhecido na ópera:

La Musique est pour l'ouie, ce que la peinture est pour les yeux. Elle doit intéresser l'auditeur, attirer son attention, en lui retraçant l'idée de ses perceptions, en variant le tableau: tantôt passer du sentiment des passions aux images physiques de la nature: tantôt du genre noble au genre familier; du ton pathétique, au ton gai; du genre sérieux, au genre brillant; de façon que ces mouvemens successifs venant à passer de l'imagination au coeur, et du coeur à l'esprit, l'ame ainsi entretenue dans cette douce agitation, ses facultés ne puissent manquer de se plaire dans un état où la variété sert d'aliment à ses plaisirs: car, pour peu qu'il y ait d'inaction, l'ame se distrait, le dégoût prend, le plaisir disparoît; tout cesse, faute de mouvement. 
Telle est la carriere épineuse que doivent remplir les arts, et sur-tout la Musique, dont les effets étant plus prompts, plus passagers, doivent être plus riches et plus variés. La Musique peut remplir cet objet par la voix, ou par les instrumens. On peut dire que le chant tient ses beautés de la nature, comme de la premiere main, et que la symphonie ne les a qu'en second. Le chant est la nature même, dont la symphonie n'est qu'une foible imitation. La voix est le mobile du chant; je la suppose aussi belle qu'on la puisse désirer: le grand art du chant ne consiste pas tant à faire briller la voix, qu'à donner aux sons une ame, des inflexions, un caractere convenable au sujet.

Car ne chanter que pour la voix, c'est ne parler qu'à l'ouie; mais nuancer le son de la voix du foible au fort, y répandre un caractere triste ou gai, sombre ou véhément, ajouter les inflexions, les agrémens convenables aux diverses expressions, augmenter ces beautés par l'ensemble du geste; de façon que l'auditeur reçoive l'impression du sujet, à ne le prendre que pour ce qu'il doit être. Voilà, je crois, le vrai art du chant; autrement ce sont des sons qui flattent l'ouie agréablement, sans parvenir jusqu'à l'ame; ce n'est plus cette illusion, cet enthousiasme, dont plusieurs de nos Orphées nous ont fait pressentir, jusqu'où pouvoit aller l'art divin d'émouvoir, de ravir les sens. Mademoiselle L. M. ne se fait-elle pas autant admirer par la belle déclamation, et par l'action, le geste, et la grande expression de son chant, que par la voix la plus mélodieuse qu'on ait jamais entendue. (Blainville, 1754, p.116-9)

[A música é para os ouvidos aquilo que a pintura é para os olhos. Ela deve interessar à audiência, atrair sua atenção, retraçar-lhe a ideia de suas percepções pela variação do quadro. Às vezes passam do sentimento das paixões às imagens físicas da natureza, às vezes do gênero nobre ao gênero familiar, do tom patético ao tom alegre, do gênero sério ao gênero brilhante, de modo que esses movimentos sucessivos passam da imaginação ao coração, e do coração ao espírito. As faculdades da alma, assim entretida com essa doce agitação, não podem deixar de agradar, num estado em que a variedade serve de alimento a seus prazeres, porque, se existe pouca ou nenhuma 
ação, a alma se distrai, o desgosto a toma, o prazer desaparece; tudo cessa pela falta de movimento.

Essa é a carreira espinhosa que deve preencher as artes, e sobretudo a música, em que os efeitos estão mais prontos, mais passageiros, devem ser mais ricos e mais variados. A música pode preencher seu objeto pela voz ou pelos instrumentos. Podemos dizer que o canto tira suas belezas da natureza, como em primeira mão, e a sinfonia, em segunda mão. O canto é a natureza mesma, da qual a sinfonia é uma débil imitação. A voz é suporte do canto. Eu a suponho assim bela o quanto posso desejar: a grande arte do canto não consiste tanto em fazer brilhar a voz, mas dar aos sons uma alma, inflexões e um caráter conveniente ao tema.

Porque se pode cantar apenas com a voz, é como falar com o ouvido, mas nuançar o som da voz do fraco ao forte, responder a um caráter triste ou alegre, sombrio ou veemente, juntar as inflexões, os encantos convenientes às diversas expressões, aumentar essas belezas pelo conjunto do gesto, de modo que a audiência receba a impressão do tema e a tome pelo que deve ser. Aqui, creio, a verdadeira arte do canto. Caso contrário, estão ouvindo sons que lisonjeiam agradavelmente, sem atingir justamente a alma. Isto não é mais do que ilusão. Este entusiasmo, em que muitos de nossos Orfeus nos fizeram pressentir, quão longe pode ir a divina arte de emocionar, de deliciar os sentidos. Mademoiselle L. M. não fez muito em se admirar pela bela declamação e pela ação, pelo gesto e pela grande expressão de seu canto, pela voz a mais melodiosa que jamais ouvi.] (Tradução nossa)

Por fim, Blainville, embora tivesse tomado partido com relação à opera seria, relatou que o problema dessas discussões era fazer comparações entre as duas nações, apesar de considerar que os franceses tinham uma visão mais racional sobre a música do que os italianos. Para ele, era um erro julgar pela comparação, mesmo tendo usado esse recurso. Sua preocupação era o fato de que a música francesa estava sofrendo modificações por influência da italiana, quando na verdade as duas poderiam ser apreciadas com as suas próprias 
peculiaridades e diferenças. Os traços característicos de cada nação, segundo o autor, deveriam diferir, do mesmo modo que os costumes e as vestimentas, que permitiam reconhecer uma nação.

Ao tomar o partido da música francesa, preocupava-se em não deixar que esta se perdesse e deixasse de existir, com todos os requintes e as regras que sempre existiram, e que, para ele, a cada dia possuíam cada vez menos importância na sociedade francesa:

D'ailleurs, il faut considérer qu'un Parisien ne voit pas les choses avec la même vivacité qu'un Provençal, et ce dernier, qu'un Italien: d'où il résulte qu'un Italien, dont l'imagination est beaucoup plus vive, ne doit voir dans notre Musique, que monotonie et lenteur. Le François, au contraire, qui voit les choses avec plus de raison et de sang froid, ne doit trouver que folie, et qu'un genre outré dans la Musique Italienne. Tous les deux auront également tort de juger par comparaison; mais il seront bientôt d'accord, lorsqu'ils jugeront séparément, et qu'ils conviendront qu'une Nation differe autant d'une autre, par ses plaisirs et ses amusemens, que par son langage, ses moeurs et ses habillemens. (Blainville, 1754, p.124-5)

[Além disso, considere que um parisiense não vê as coisas com a mesma vivacidade que um provençal, nem este como um italiano, do que resulta que um italiano, de imaginação muito mais viva, não deve ver na nossa música mais do que monotonia e lentidão. $\mathrm{O}$ francês, ao contrário, vê as coisas com mais razão e compostura e deve encontrar na loucura outro gênero na música italiana. Os dois estão igualmente errados em julgar por comparação, mas brevemente estarão de acordo quando julgarem em separado, e quando concordarem que uma nação difere de outra pelos seus prazeres e seus divertimentos, pela sua linguagem, seus costumes e suas vestimentas.] (Tradução nossa)

Os fragmentos de textos analisados nesta parte do livro nos deram um parâmetro sobre como a ópera era representada, como as transformações na primeira metade do século XVIII levaram ao 
afrouxamento da exigência do cumprimento das regras das teorias imitativas na composição das óperas.

Dubos e Batteux viveram em um momento de transição de uma visão racionalista da música para uma visão subjetiva, e expressaram isso em seus tratados. Paralelamente a eles, os autores Grandval, Bollioud-Mermet e Blainville abordaram acontecimentos do dia a dia na ópera, relativos à representação, ao nível do público frequentador, à recepção da ópera italiana. Esses últimos autores concordavam que as regras deveriam ser observadas e mantidas na composição musical e demonstraram seu descontentamento por não estarem sendo cumpridas, o que consideravam uma decadência da ópera francesa. Para eles, cada elemento deveria ter seu lugar específico, como no caso da música instrumental, que deveria possuir o status de acompanhamento e realçar a música vocal.

Até a primeira metade do século XVIII, a música ainda era vista como uma representação teatral e o gosto era moderado pelo componente tradicional. A imitação da natureza deveria sempre possuir os traços das formas poéticas da Antiguidade e do teatro de Corneille e Racine do século XVII.

A manutenção dessa tradição e do elemento imitativo da natureza na composição da ópera foi questionada, e todas as explicações sobre o que era a música e os seus significados não foram suficientes para exprimir o que ela era de fato. Pela concepção racional, o que explicava a música era o componente verbal, que deveria estar sempre em evidência, e não a sua maneira de ser. Falava-se da linguagem e de seus modelos imitativos, mas não dos seus significados. Daí a ópera, mesmo se valendo da imitação para se constituir como um espetáculo verdadeiro, não cumprir totalmente com essa prerrogativa.

No próximo capítulo observaremos como os ataques à tradição e a aceitação da ópera italiana colocaram o elemento expressivo em evidência na música e por que a imitação da natureza não cumpria totalmente a sua função na ópera. 


\section{3 \\ FRANÇA NA SEGUNDA METADE DO SÉCULO XVIII: \\ O MOVIMENTO DAS QUERELAS A EXPRESSÃO EM MÚSICA}

\section{O riso e o cômico: a Querelle des Bouffons e o repúdio à opera seria}

Nos capítulos anteriores observamos as transformações pelas quais passou o conceito de imitação, na ópera francesa, no decorrer do século XVIII. Para o pensamento racionalista da época, aspectos estritamente literários eram atribuídos à ópera. O texto literário, através da linguagem verbal, representava a ação, o elemento racional exigido para a música. Esta, em sua característica individual, não satisfazia a essa exigência, por ser considerada, de acordo com o pensamento da época, inferior à poesia e à matemática. A poesia era universal, e dela se extraía a verossimilhança e o que era necessário para a representação da ópera e do teatro, além de ser considerada mais filosófica.

As poesia e a matemática explicavam a realidade do mundo. A poesia expressava com precisão e racionalidade a formalidade do mundo observada pela física e pela matemática. Em conformidade com a satisfação da razão, a ópera, ainda no século XVII, era a representação das paixões humanas. Estas eram mais bem expressas pelo recitativo, pois o aspecto textual e oratório da música vocal aproximava-se da linguagem falada, permitindo que o significado 
das paixões fosse bem compreendido. Assim, as palavras estabeleciam a proporção dos sentimentos, os quais poderiam, por meio da linguagem verbal, ser controlados pela razão. Para as artes, a poesia possuía regras definidas, que deveriam ser seguidas na sua composição, as quais se reportavam à imitação da natureza, mas de acordo com os moldes da poesia clássica. Seguir as regras e reconhecer seus traços nas óperas e nas obras de arte denotava um ótimo bom gosto.

As regras imitativas para a ópera não eram usadas apenas para reforçar a tradição da Antiguidade e da tragédia clássica francesa. Com cada elemento em seu devido lugar, elas representavam também a hierarquia monárquica, e a ópera espelhava esse poderio absolutista. Ela era um privilégio de distração, sedução e dominação, daí a suntuosidade de sua produção e seu aspecto de aparato da majestade. A ópera traduzia o espírito e a mentalidade aristocráticos, expressos tanto pela música como pelo texto. A música estava a serviço da compreensão do texto literário, e para que as intenções e as inflexões das palavras ganhassem evidência e adquirissem a intensidade necessária, o sentido delas deveria ser representado. $\mathrm{O}$ conteúdo extramusical e a ideia poética teriam na ópera a concretização do gesto vivo da palavra e da sua eloquência. Dentro das normas estabelecidas pelas regras das teorias imitativas, teriam uma ordenação que faria despertar paixões específicas nos ouvintes, assim como o controle da intensidade de cada uma delas. Nesse sentido, para obter esses resultados das paixões, primeiramente elas deveriam satisfazer às condições racionais, pois tudo era controlado.

A imitação da natureza, que era a origem de tudo e fornecia todas as condições e todos os modelos para as realizações artísticas, desde o Renascimento era o meio para compor a ópera, constituída por regras e hierarquias definidas em sua estrutura. Essa maneira de compor ópera foi praticada desde o século XVII, e Lully, seu maior expoente, foi considerado o compositor que verdadeiramente seguia as regras do bom gosto. Porém, após a sua morte, o aspecto imitativo na composição de óperas foi se transformando e até mesmo passou a ser desprezado, devido às novas exigências de gosto da nova classe social em ascensão: a burguesa. A ascensão 
social dessa classe foi um dos aspectos dessa transformação, não o único. A música instrumental também começou a apresentar problemas para a reflexão, para as teorias e exigências relativas à imitação. Também o papel do ouvinte e suas exigências fizeram modificar o conceito de imitação. Parte da aristocracia preferiu outra forma de fazer ópera, mesmo com a presença de um compositor ainda representante da classe conservadora, Jean-Philippe Rameau (1683-1764). ${ }^{1}$ Esse dispositivo imitativo baseado em modelos retirados da natureza e julgado conforme a razão sofreu uma inversão, e o sentimento ${ }^{2}$ passou a ser o elemento relevante no julgamento de uma ópera ou de uma obra de arte.

Essa inversão trouxe mudanças drásticas para as composições de ópera, porque o modelo externo ao artista, a bela natureza, perdeu importância em prol de aspectos internos, como o próprio sentimento do artista. Dessa maneira, a teoria imitativa, como regra, se transformaria e entraria em declínio em nome do caráter subjetivo da música, que nesse momento passaria a ter nela a linguagem dos sentimentos e dos significados emocionais, uma novidade nesse momento da história musical francesa, que permitiu, através das emoções, que fosse dado significado à música. Mas, pela razão, a retirada do elemento verbal da música impunha uma questão difícil de resolver, já que, sem esse aspecto, ela era considerada destituída

1 A estética musical clássica de Rameau prendia-se a uma concepção racionalista e mecanicista da natureza e do homem que fazia que rapidamente ela se esgotasse, e também as bases sobre as quais se organizava a sociedade do Ancien Régime. Assim, quando os philosophes ingressam na Querelle dos Bufões, seu ataque à ópera tradicional de Rameau é antes um ataque a toda uma visão de mundo, a qual pretendiam superar. A "Carta sobre a música francesa [de Rousseau] não foi meramente uma manobra tática, mas um importante passo para a constituição de uma estética musical baseada em princípios inteiramente diversos dos de Rameau, indispensável para compreender a imensa revolução musical das décadas posteriores" (Almeida Marques, 2005, p.3).

2 O sentimento já havia se tornado uma categoria de julgamento da música e da obra de arte, mas preso às regras do bom gosto, baseado na imitação da bela natureza, como observado por Dubos e Batteux. Posteriormente, ele continuou como critério no julgamento da música, mas já sem o aspecto imitativo requerido na composição das óperas. 
de significado. Nesse momento, ocorreram as Querelles des Bouffons [Querelas dos Bufões], iniciadas quando uma companhia itinerante de óperas bufas se instalou em Paris, em 1752, e passou a apresentar óperas e intermezzi, com sucesso crescente. Isso levou a sociedade a dividir-se e confrontar-se. Parte dela era a favor da ópera bufa italiana - os chamados "bufonistas" - e outra parte, a favor da opera seria francesa. Os defensores da ópera italiana atacavam nos franceses a sua maneira rígida de compor ópera, espelhada, nesse momento, na figura de Rameau, considerado não só uma expressão da maneira tradicional de fazer ópera, mas também da aristocracia, contra a qual os enciclopedistas se voltaram. A dimensão dessa discussão assumiu proporções de cunho ideológico, a ponto de os enciclopedistas participarem dessa polêmica.

Não bastassem as reflexões sobre o significado da música, se ela deveria ou não imitar e no que consistiria essa imitação, e sobre a música instrumental, que cada vez mais conquistava o gosto e a apreciação do público, essas querelas trouxeram debates sobre a comparação entre a música francesa e a italiana, que se referiram, mesmo que indiretamente, ao valor da imitação como critério de criação e valoração musical.

Dado o desencanto que o grande público começara a sentir em relação à ópera, ele passara a ir à Ópera apenas para ver os balés, já que eles eram até mesmo mais importantes do que o espetáculo em si, e não mais a grande ópera. Quando as óperas bufas chegaram, com enredos divertidos, tirados do cotidiano, ganharam a adesão do grande público. Para os partidários da música francesa, "rir" na ópera era algo absurdo, já que as regras das teorias imitativas não eram seguidas. $\mathrm{O}$ enredo padrão de uma ópera bufa consistia numa sequência de cenas cômicas, sem nenhum elemento estranho à sua ação, e ela não precisava de muitas personagens. Sua força estava na expressão realista dos sentimentos do dia a dia, evocados nas situações da vida das personagens, na rapidez do ritmo das ações e na própria música, feita com maior número de árias, diferente da opera seria francesa, feita com maior número de recitativos, os quais representavam para ela as maiores cenas dramáticas. 
Sobre a dimensão do significado da representação de óperas italianas na Ópera de Paris e do quanto isso contribuiu para manter acirradas as querelas, o professor de literatura italiana Andrea Fabiano (2005), da Sorbonne Paris IV, escreveu:

A teorização e a realização de um modelo francês de teatro musical no século XVII são a base, de uma parte, da vontade de dar uma resposta política nacionalista ao desafio da ópera italiana importada por Mazarin; de outra parte, a consciência de que a recepção francesa levou em conta - mesmo no teatro musical - as regras dramatúrgicas da poética clássica. A ópera francesa se revelou assim como um espelho invertido e um complemento, ainda que por uma sublimação, do teatro clássico, e não como um testemunho isolado da arte barroca. Essa alteridade francesa criou uma barreira diante da ópera italiana, única em toda a Europa, e permitiu ao mesmo tempo uma autarquia bem sucedida do ponto de vista da criação dramático-musical.

Na metade do século XVIII esse sistema entrou em crise: a asfixia do repertório, malgrado o gênio inovador de Rameau; a crise poética do modelo clássico; a crise institucional da Academia Real de Música, detentora de um privilégio exclusivo sobre toda a França; a crise da recepção devido à mudança de exigências do público. Nesse contexto de fragilidade e de transformação, o debate, sempre latente e jamais extinto, entre os partidários da ópera francesa e os partidários da ópera italiana, assumiu uma amplitude inesperada e inimaginável, que revelou, por detrás da motivação musical, a exigência profunda, colocada a nu, do modelo político-cultural do absolutismo do Antigo Regime.

A Querela dos Bufões não foi apenas uma disputa a favor ou contra a ópera italiana [...], mas a revelação de uma surpreendente sinapse conflituosa cujas repercussões marcaram uma transformação fundamental na cultura francesa da segunda metade do século XVIII. (p.11, tradução nossa)

A discussão sobre música francesa e italiana já havia se iniciado no começo do século XVIII, com Raguenet e Lecerf, e continuou posteriormente com as querelas, envolvendo, além da compara- 
ção entre os dois países, questões de melodia e harmonia. Mas, desta vez, envolveu também a recepção do público com relação à ópera bufa, além de tomadas de partido por parte de filósofos e enciclopedistas.

O teatro clássico francês, do qual a opera seria francesa se constituiu, possuía uma rigidez e uma transparência racionalmente codificadas. O conhecimento de suas regras, a capacidade de desconstruir e reconstruir os objetos teatrais fundamentavam-se numa extrema reserva social alimentada pela dramaturgia francesa. A ópera bufa, vista como opaca em termos de dramaturgia, trouxe um problema em relação à opera seria: o modo reservado desta não permitia a livre circulação nas salas de concerto, e a manifestação da outra nos salões, devido a diferenças de costumes. Quando essa ópera foi conquistando espaço nos meios aristocráticos, despertou fascínio e suscitou paixões, assim como repulsa, nos espectadores, pois mostrava-se aos seus olhos como um processo primário, com livre apelo aos sentidos, os quais não tinham ligação uns com os outros, gerando uma ilusão em relação aos afetos, considerados mal compreendidos pelo teatro clássico e em desacordo com os preceitos das regras das teorias imitativas.

Os modelos interpretativos e imitativos para as óperas, sedimentados e compartilhados entre os autores dramáticos, os compositores e o público culto, que exigiam o conhecimento racional do funcionamento da obra representada, viam seus costumes neutralizados e até mesmo não utilizados (já que deveriam, pela razão, aperfeiçoar os costumes) nas representações de óperas bufas, pois subitamente elas abriram espaço para a inserção da ingenuidade e da sensibilidade natural, com forte apelo unicamente aos sentidos.

Para a exigência desse público culto, aristocrático, defensor da ópera francesa, esse tipo de representação destruíra o bom gosto natural e também o bom gosto construído pela educação, pois a legitimidade de uma nova forma de crítica $^{3}$ em relação aos fenômenos

3 O sentido de "crítica", nesse contexto, era o de observar se as regras do bom gosto, segundo os moldes da cultura clássica, estavam sendo rigorosamente seguidas. 
musicais e teatrais, também novos, fundamentava-se num vocabulário diferente, que apelava para as sensações, que tentava explicar esses fenômenos italianos e que trouxe uma forma de apreciação musical inédita, não calcada na razão transmitida e reconhecida pelas regras.

A apreciação artística feita de maneira intelectual baseava-se na convicção de se ter transmitido o modelo estudado e realizado de acordo com as regras. Esse modelo fora deslocado do centro da cultura clássica, devido à descoberta e à representação dessa nova forma dramático-musical, vista como não controlada, incapaz e incompetente, a ponto de gerar uma acirrada polêmica entre as duas nações na Ópera de Paris.

A tragédia lírica (ou tragédia em música) e a ópera bufa foram comparadas, segundo Andrea Fabiano (2005, p.18), de maneira absurda, pois, no confronto entre as duas óperas, a comparação não era possível, por elas serem incompatíveis em termos racionais. Cada nação tinha seu próprio modelo. A ópera francesa, representada por Rameau, e a italiana, representada pelos intermezzi de Giovanni Battista Pergolesi (1710-1736), eram opostas uma à outra. A ópera francesa representava uma civilização autocentrada e autorreferenciada, em estado luminoso, para a qual o gênio ditou a racionalidade, a elaboração e a complexidade de uma arte civilizada, enquanto a ópera bufa era vista como pertencente a uma civilização decadente, sem atingir o limite da racionalidade, cuja arte não possuía regras de civilidade.

No entanto, partidários da ópera italiana identificaram nessa visão da decadência do gênio italiano, considerado inferior em relação ao Renascimento italiano, um estado primitivo positivo, pois permitiria reconstruir uma identidade fundamentada na naturalidade, na simplicidade e na espontaneidade, abrindo espaço para uma maneira de ser mais leve e livre do jugo do racionalismo presente na ópera francesa.

O contraste entre as duas óperas trouxe reflexões sobre novos valores poéticos opostos ao sistema clássico francês. As deficiências italianas das óperas fizeram homens de letras e filósofos exaltarem 
sua simplicidade vocal e harmônica, porque isso permitia explorar o verdadeiro caráter das nações, sem manipular, transformar ou submeter os acontecimentos reais às exigências de uma visão teórica. As ações das óperas, como no teatro, se submetiam à teorização reconhecida pela razão na tradição clássica francesa, enquanto a simplicidade e a espontaneidade da ópera italiana se dirigiam ao coração, ao elemento interno, sem a necessidade da razão como mediadora entre representação e público.

Para os defensores da opera seria francesa, se a imitação da natureza não ocorresse de maneira clara e segundo os moldes da tradição clássica, os costumes não seriam representados, o que colocaria em risco a própria ideia de caráter nacional francês. Daí a grande repercussão das Querelas dos Bufões. A ópera italiana mexeu com o coração da própria identidade francesa, representada pelo absolutismo monárquico. A obsessão dos franceses em cultuar a si mesmos e a seguir as regras tradicionais era tamanha que, para habilitar e comunicar ideias e sentimentos, a música foi se tornando mais simbólica, a ponto de até mesmo a música instrumental seguir uma representação cujo conteúdo imitativo era indicado pelos próprios títulos das peças. Esses estereótipos tornavam a música, segundo a concepção da época, apta a expressar as diferentes paixões, sentimentos ou emoções, de forma regulada e prevista pelo compositor.

As querelas demonstraram de modo veemente que as regras das teorias imitativas para as artes e para a ópera estavam sendo deixadas de lado em nome de uma maneira considerada mais leve de fazer música. Aqueles que não tinham mais na opera seria o prazer artístico, no entanto, encontraram deleite na ópera cômica, que misturava em suas representações, dentre outros elementos, personagens da tragédia e da comédia (o que era proibido na opera seria) e fazia paródias da aristocracia. Essas querelas levaram a se reconsiderar na França a concepção de tragédia em música, símbolo, portanto, da uma monarquia que se via em naufrágio.

A identidade social de boa parte da produção musical dos séculos XVII e XVIII, na França, era principesca e aristocrática, não somente pela sua origem, mas também pela sua destinação ao público da corte e às residências aristocráticas. $\mathrm{Na}$ verdade, ela vivia num 
recolhimento que rodeava somente os soberanos, já que fora usada com fins políticos e como meio de representar as hierarquias sociais no absolutismo francês.

As representações da ópera italiana, em alternância com as da ópera da Academia Real de Música, foram tumultuadas e mantiveram uma discussão que se iniciara já em 1702, entre Raguenet e Lecerf, retomadas fervorosamente em 1752 com as Querelas dos Bufões, diminuindo em 1754 e assim mantidas em seu fervor em 1753, com a Lettre sur la musique française [Carta sobre a música francesa], de Jean-Jacques Rousseau, na qual, embora não tivesse dado tanta importância à Querela dos Bufões e houvesse se revelado partidário da música italiana, o autor colocou na discussão entre a música francesa e a italiana seu ataque frontal à primeira, principalmente à figura de Rameau.

Os dois concordavam que a música era uma arte imitativa, mas a concepção e compreensão da natureza eram diferentes para eles. Rameau enxergava a natureza como um domínio racional, cartesiano, uma ciência matemática em que suas relações explicavam a física da natureza, o que justificava a primazia da harmonia, já que esta era a combinação de consonâncias de sons a partir de ressonâncias produzidas pelos corpos físicos e observadas de maneira racional. Para Rousseau, essa mesma natureza significava e expressava os sentimentos humanos, além do mundo interno das paixões. Eram os sentimentos que justificavam a primazia da melodia, representada pela arte dos acentos da linguagem falada, comunicando as paixões humanas. Cada dimensão, harmonia e melodia foi tomada por cada um dos dois como o meio mais adequado de imitação da natureza. ${ }^{4}$ Rousseau teve importante papel no novo conceito de

4 Embora a primazia da harmonia ou da melodia, embate travado entre Rameau e Rousseau, também tivesse sido importante nas discussões envolvidas nas querelas, elas não são foco deste livro. Apenas foram mencionadas para mostrar as diferentes concepções de imitação da natureza dos dois autores em meio às Querelas dos Bufões. Apenas em 1754 Rameau publicou, em resposta à Carta sobre a música francesa, de Rousseau, suas Observations sur notre instinct pour la musique [Observações sobre o nosso instinto para a música], em que fez a defesa de Lully, que havia sido atacado na Carta de Rousseau. 
natureza. Como esta possuía a verdade e o conhecimento, era ela que orientava o ouvinte, que o fazia se reportar aos próprios sentimentos. A natureza ganhou outro sentido, o de orientar o ouvinte na sua escuta e nos seus sentimentos.

$\mathrm{Na}$ Carta, Rousseau recriminou a ópera francesa, acusando-a de ser um gênero falso, no qual a natureza não se fazia lembrar por nada. Condenou assim todas as regras imitativas da natureza segundo os moldes clássicos e as convenções da ópera, declarando que os libretos abusavam de uma mitologia mais do que conhecida, que a ópera naquele momento não possuía mais ação dramática, que a sua parte musical era composta de árias com excesso de trinados e gesticulações comuns a praticamente qualquer outra ópera, que havia pouca expressividade no canto, além de as representações serem exageradas, com uma instrumentação excessivamente densa e complicada, e que todos esses elementos não tinham relação com os sentimentos que o libreto expressava, devido à pouca ligação entre música e texto. Junto com isso, ele salientou que a musicalidade da língua italiana era superior à da francesa, considerando, assim, que qualquer compositor italiano era superior aos compositores franceses.

Rousseau procurou ainda destruir as bases do sistema harmônico de Rameau ao atacar sua ópera Armide, o qual respondeu em 1754 à sua crítica, defendendo a prioridade da harmonia. Criticou ainda a maneira como os franceses viam a música italiana e fez considerações sobre as árias francesas:

[...] a prova mais marcante de que a música francesa não sabe nem pintar nem contar é que não pode desenvolver o pouco de belezas de que é capaz a não ser através de palavras que nada significam. No entanto, ao ouvir os franceses falarem de música, crer-se-ia que é em suas óperas que ela pinta grandes quadros e grandes paixões, e que na ópera italiana há apenas arietas, quando, de fato, esse próprio termo "arieta" e o ridículo que ele exprime é desconhecido na ópera italiana. Mas não nos surpreendamos com a grosseria desses preconceitos: nem mesmo entre nós a música italiana tem oponentes, exceto aqueles que dela nada conhecem; e todos os fran- 
ceses que tentaram estudá-la com o único objetivo de criticá-la com conhecimento de causa, logo se tornaram seus mais zelosos admiradores.

Após as arietas, que fazem em Paris o triunfo do gosto moderno, vêm os famosos monólogos admirados em nossas antigas óperas. Sobre isso se deve observar que nossas mais belas árias não têm nenhuma atuação muda, e a música não indica nenhum gesto nem pinta nenhuma situação, aquele que está em silêncio não sabe o que fazer de sua pessoa enquanto o outro canta.

O caráter arrastado da língua, a pouca flexibilidade de nossas vozes, e o tom lamentável que reina perpetuamente em nossas óperas colocam quase todos os monólogos franceses em um andamento lento, e como o ritmo não se faz sentir nem no canto, nem no baixo, nem no acompanhamento, nada é tão arrastado, tão frouxo, tão langoroso como esses belos monólogos que todo mundo admira bocejando; pretendem ser tristes, mas são apenas tediosos; quereriam tocar o coração, e só conseguem afligir os ouvidos. (Rousseau, 2005, p.27)

A partir do próximo fragmento da Carta de Rousseau, pode ser feita uma comparação com Lecerf, no início do século XVIII, quando ele disse que a música italiana em nada poderia se comparar à francesa porque não estava de acordo com as regras do bom gosto, já que os italianos forçavam demais os instrumentos e adornavam demais a melodia de suas árias. Rousseau, cinquenta anos depois da Comparação da música italiana e da música francesa, de Lecerf, criticou nos franceses os mesmos exageros que apontou na música italiana:

Mas o que impede de maneira mais eficaz a monotonia e o tédio nas tragédias italianas é a vantagem de poder exprimir todos os sentimentos e pintar todos os caracteres com o ritmo e o andamento escolhidos pelo compositor. Nossa melodia, que nada diz por si mesma, tira toda sua expressão do andamento que lhe é dado; ela é forçosamente triste em um ritmo lento, furiosa ou alegre em um 
andamento vivo, grave em um andamento moderado: o canto não produz quase nada; é o mero compasso - ou antes, para falar mais corretamente, o mero grau de velocidade - que determina o caráter. Mas a melodia italiana encontra em cada andamento expressões para todos os caracteres, imagens para todos os objetos. Ela é, quando apraz ao compositor, triste em um andamento vivo, alegre em um movimento lento, e, como eu já disse, muda de caráter num mesmo andamento à escolha do compositor; o que lhe dá a facilidade de estabelecer contrastes sem depender para isso do poeta, e sem se expor a contrassensos.

Eis a fonte dessa prodigiosa variedade que os grandes mestres da Itália sabem verter em suas óperas sem jamais afastar-se da natureza; variedade que evita a monotonia, a frouxidão e o tédio, e que os músicos da França não podem imitar porque seus andamentos são dados pelos sentidos das palavras, forçando-os a ater-se a eles, se não quiserem cair em contrassensos ridículos. (Rousseau, 2005, p.28)

Os italianos, até então considerados pelos franceses, no que se referia à ópera, afastados da natureza, foram nesse momento considerados por Rousseau próximos dela, além de saberem fazer uso da variedade que o gênero proporcionava para as artes. Ele afirmou ainda que os franceses não sabiam imitar porque não se atinham à natureza, mas sim ao andamento das palavras, e por isso a música não tinha variedade nem caráter definido para os sentimentos. Ocorreu uma inversão no que se refere à imitação do início do século até a sua metade, como se os franceses tivessem se tornado um exemplo de mau gosto, fazendo uma música apagada e sem variedade alguma, enquanto os italianos representavam o equilíbrio e a verdadeira expressão da natureza na ópera.

O recitativo, do qual os franceses se orgulhavam tanto, no qual colocavam na composição toda a carga dramática na representação operística, mais até do que nas árias, considerando-o equivalente à declamação dos antigos e a melhor escola de recitação da Europa, também foi alvo das críticas de Rousseau: 
Juntem-se a isso os trêmulos, as cadências, as apojaturas que ocorrem a todo instante, e digam-me que analogia pode haver entre a fala e toda essa enfadonha ornamentação; entre a declamação e esse pretenso recitativo? Mostrem-me ao menos um aspecto que permita razoavelmente enaltecer o maravilhoso recitativo francês cuja invenção faz a glória de Lully?

É cômico ouvir os partidários da música francesa refugiarem-se no caráter da língua e lançarem sobre ela os defeitos de que não ousam acusar seu ídolo, ao passo que é muito claro que o recitativo mais adequado à língua francesa deve opor-se em quase tudo ao que é praticado; que ele deve fluir por intervalos muito pequenos, não elevar nem abaixar muito a voz, ter poucos sons sustentados, nenhum estrépito, menos ainda gritos, nada, sobretudo, que se assemelhe ao canto, pouca desigualdade na duração ou valor das notas, bem como em seus graus. Em duas palavras: o verdadeiro recitativo francês, se é que pode haver um, só será encontrado em uma direção completamente oposta à de Lully e seus sucessores, em algum novo caminho que certamente os compositores franceses, tão orgulhosos de sua falsa sabedoria, e, consequentemente, tão distantes de sentir e de amar a verdadeira, não se oporão a procurar tão cedo, e que, provavelmente, não encontrarão jamais. (Rousseau, 2005, p.30)

Rousseau, defensor da melodia sobre a harmonia, ainda declarou que o recitativo italiano era de fato o que tinha todas as condições para uma boa realização, que apresentava a vivacidade da declamação e a energia da harmonia, que era tão melodioso como o próprio canto, além de refletir todas as paixões, com as suas inflexões e propriedades, como só um verdadeiro discurso era capaz de fazer.

Para os partidários da opera seria, a ópera francesa era racional, igual em todos os lugares e em todas as épocas, e sua compreensão era universal, já que a natureza, como elemento comum e universal entre todos os povos, expressava-se pela matemática e era descrita pela poesia. O elemento novo, como razão, era a harmonia, instaurada por Rameau. Para Rousseau, no entanto, a música não poderia ser universal, porque expressava a infinidade das variedades do co- 
ração humano, e suas diferenças não constituiriam um fundamento único e universal. Prova disso, segundo ele, eram as variedades melódicas entre os povos e as culturas e sua diversidade nas várias épocas da história. A música, para Rousseau, não observava qualquer regra, era sinônimo de liberdade, e expressava os sentimentos, enquanto para os partidários da opera seria ela expressava a razão.

Os debates em torno da liberdade que a música italiana proporcionava aos ouvidos versus a rigidez das regras que a ópera francesa seguia mantiveram vivas as chamas de um dos problemas existentes nos séculos XVII e XVIII, que eram as relações entre som e verbo, entre poesia e música, e a música como imitação da natureza estava entre elas. As querelas entre a França e a Itália e a definição do conceito de gosto estiveram vinculadas a essas relações, e da metade do século XVIII em diante a ópera já não tinha mais na natureza apenas um sinônimo de razão e equilíbrio, mas também de sentimento, ideia da qual Rousseau era partidário.

Com relação às diferentes concepções de imitação entre Rousseau e Rameau, este considerava-a uma ciência da música capaz de reproduzir relações sonoras que correspondiam às relações da própria natureza. A melodia só poderia nascer dessas relações harmônicas, de forma agradável e racional, através da ressonância dos corpos físicos, das proporções derivadas da harmonia, o que justificaria o fato de ela ser esteticamente agradável, pois essas proporções eram fundamentadas na natureza, e a música refletiria, na verdade, as suas leis universais. Dentro da estética clássica e racionalista, refletir as leis universais da natureza estava não naquilo que era de fato concreto e particular nela, mas sim no que deveria parecer ser, e a concretude e os acontecimentos do mundo, na música, também deveriam ser verossimilhantes como o eram para a poesia, o teatro e a pintura. Não deveriam reproduzir, necessariamente, a realidade, mas parecer sê-la. ${ }^{5}$

5 No quadro da estética clássica, Rameau seguia ainda a concepção francesa, racionalista. Com relação à imitação, concordava com o que diz o Livro IX da Poética de Aristóteles. 
Assim como no teatro clássico as ações deviam estar de acordo com os caracteres das personagens e segundo os princípios gerais que regiam as condutas e as paixões humanas, agradar ao ouvinte perante a música seria possível se os sons dela fossem combinados de acordo com os princípios universais determinados pela própria natureza. Em ambas as artes - teatro e música -, a natureza era o alcance mais profundo daquilo que se deveria imitar ou representar. O que cada arte fazia era usar de suas convenções e artifícios como instrumentos de imitação, mas sem se afastar dos modelos da natureza.

Para Rousseau, a natureza a ser imitada era outra. Ela não era mais material, física, com a observância de suas leis rígidas e imutáveis. Para ele, a natureza consistia no que era dado imediatamente à experiência do ouvinte, no que se referia à carga passional e emotiva das paixões. No domínio da música, essa noção, já vinda com Dubos e Batteux, tendo o sentimento como critério de julgamento de uma obra de arte e da ópera, embora devessem ser respeitadas as teorias imitativas e racionais da natureza, modificou-se, e a ideia de imitação da natureza ganhou novo significado. Os espetáculos reproduziriam os estados emotivos que o ouvinte experimentava diante deles, bastando usar acentos musicais para a reprodução dessas emoções, e não mais a imitação dos sons da floresta ou das aves, para citar alguns exemplos. Quando se faziam essas imitações, não era a floresta nem as aves que a música imitava, mas sim os sentimentos produzidos quando se contemplavam esses objetos. Essa era a representação almejada por Rousseau, que viu na música italiana a concretização dessa maneira de imitar. A música configurava-se então como uma nova linguagem para comunicar as paixões humanas. Sua concepção de música era a de representação dos sentimentos.

Por esses motivos, a melodia, dentro dessas discussões, assim como tantos outros aspectos observados na época, era prioritária em relação à harmonia. A música teria sua origem e sua expressividade nos acentos da voz humana, na sua forma de comunicar as 
paixões humanas, e nada mais deveria ser notado a não ser a melodia, suplantando mesmo a harmonia. A música, na sua concepção, só poderia ser compreendida do ponto de vista ético das paixões. Por essa razão, por ser a linguagem das emoções, ela não poderia ser explicada em termos racionais e físicos.

Além de Rousseau, outros autores, como D'Alembert, posicionaram-se em relação às polêmicas, e não somente no que dizia respeito às Querelas dos Bufões, mas também a questões que envolviam a comparação entre a música italiana e a francesa. Dele temos o seguinte fragmento de texto, que faz parte de um conjunto de outros fragmentos, chamado Fragment sur l'opéra [Fragmentos sobre ópera], provavelmente de 1752, anterior à Carta de Rousseau:

L'Opéra est le vrai théâtre de la musique; elle a besoin pour recevoir l'expression dont elle est susceptible, d'être appliquée à des paroles et à des danses. Il s'en faut bien qu'elle produise le même effet dans la musique purement instrumentale. Lucien disoit avec raison, que la musique qu'on n'entend point est inutile. Toute symphonie qui ne dit rien à l'âme est à peu près comme un discours allemand prononcé devant quelqu'un qui n'entendroit que le français. Une sonate est proprement un dictionnaire de mots, dont la collection ne forme aucun sens, ou si l'on veut, c'est une suite de traits dont les couleurs ne représentent rien.

C'est bien pis quand le mérite de cette sonate, comme il n'arrive que trop souvent, ne consiste que dans la difficulté vaincue, ce qui faisoit dire à un homme d'esprit après avoir entendu une musique qu'on lui vantoit, comme très difficile: "Je voudrois qu'elle fût impossible." Nous avons vu, il y a environ trente ans, un célèbre virtuose sifflé au concert spirituel: les spectateurs avoient tort de ne rendre pas la justice qu'ils devoient à une exécution admirable et le virtuose n'avoit pas raison de jouer devant de pareils auditeurs une musique trop peu faite pour leurs oreilles. "Il ne faut pas s'enquérir, dit Montaigne, qui est le plus savant, mais qui est le mieux savant." Et cette maxime est applicable à la musique comme à d'autres objets. (D'Alembert, I, (?) 1752, p.155-6) 
[A ópera é o verdadeiro teatro da música; ela necessita ter a expressão que pode ser aplicada às palavras e às danças. É preciso que ela produza o mesmo efeito na música puramente instrumental. Lucien dizia com razão que a música que não se entende é inútil. Toda sinfonia que nada diz à alma é pouco mais que um discurso alemão pronunciado para alguém que não entende além do francês. Uma sonata é como um dicionário de palavras em que o conjunto não forma nenhum sentido, ou é um conjunto de traços para o qual as cores nada representam.

É bem pior quando o mérito dessa sonata, como ocorre com bastante frequência, não consiste mais do que em dificuldades vencidas, em se dizer a um homem de espírito, depois de ter ouvido uma música que se vangloria de ser muito difícil: "eu gostaria que ela fosse impossível”. Nós vimos, há cerca de trinta anos, um célebre virtuose sussurrar num concerto espiritual: os espectadores estavam errados em não render a justiça que deviam diante de uma execução admirável, e o virtuose não tinha razão de tocar diante de tal auditório uma música pouco feita para os seus ouvidos. "Não se deve considerar, disse Montaigne, que o mais sábio é o que melhor aprende." E esta máxima é aplicável à música, como a outros objetos.] (Tradução nossa)

Para D’Alembert, a música só conseguiria se expressar se fizesse uso das palavras, da linguagem verbal, demonstrando assim sua posição frente ao racionalismo e à maneira de compor ópera. Declarou que a música instrumental deveria produzir o mesmo efeito dos significados das palavras, pois, para ele, tudo o que não se compreendia era inútil, e a música instrumental se enquadrava nessa categoria; a vocal era a música que proporcionava a compreensão.

D'Alembert ainda observou em seus Fragments sur la musique en général et sur la notre en particulier [Fragmentos sobre a música em geral e a nossa em particular], de 1752, o fascínio que a música italiana provocava nos franceses, mesmo tendo ouvido a música francesa desde a infância. Em meio às polêmicas envolvendo a música dos dois países, esse fascínio poderia explicar a adesão de muitos 
franceses à música italiana, já que a Itália foi o berço das artes e das ciências no Renascimento:

La musique, à la Renaissance des Arts et des Lettres, s'est perfectionnée peu à peu, comme tous les autres arts. L'Italie a été son berceau, ainsy que de la peinture, de la sculpture et des sciences. Ce pays, en qui la nature avoit fait une espèce d'effort dans les siècles de barbarie et d'ignorance, semble aujourd'hui se reposer, excepté pour la musique, qui est demeurée comme son patrimoine. Tous les étrangers l'ont adoptée, et c'est une espèce de préjugé général en sa faveur; les étrangers ont appris notre langue, s'en servent communément, et ne peuvent souffrir notre musique. On ne peut accuser ce choix de bizarrerie, et les François même qui vont en Italie, malgré leur penchant pour la musique qu'ils ont entendue dès l'enfance, reviennent presque tous admirateurs passionés de la musique italienne. (D'Alembert, 1752, IV, p.166)

[A música, no Renascimento das artes e das letras, se aperfeiçoou pouco a pouco, como todas as outras artes. A Itália foi o seu berço, assim como da pintura, da escultura e das ciências. Esse país, em que a natureza tinha feito uma espécie de esforço nos séculos da barbárie e da ignorância, parece hoje repousar, exceto pela música, que permaneceu como sua herança. Todos os estrangeiros a adotaram, e há uma espécie de prejulgamento geral em seu favor. Os estrangeiros que aprenderam nossa língua se servem comumente dela, e não podem sofrer pela nossa música. Não se pode acusar de escolher a bizarrice, e os franceses, mesmo os que vão à Itália, malgrado sua inclinação pela música que ouvem desde a infância, voltam quase todos como admiradores passionais da música italiana.] (Tradução nossa)

As polêmicas entre música italiana e francesa ainda continuaram, mesmo depois do movimento das Querelas dos Bufões. O próprio D'Alembert retomou o que escreveu o Abade Raguenet no início do século e traçou um paralelo com a Carta sobre a música 
francesa, de Rousseau. Ele fez diversos apontamentos sobre as discussões em si, sobre as polêmicas, como mostra este fragmento de 1759, retirado do seu escrito De la liberté de la musique [Da liberdade da música]:

Ce n'est pas la premiere fois qu'on a manqué de respect à la Musique Françoise dans le lieu même de son empire. Au commencement de ce siecle, l'Abbé Raguenet, Ecrivain d'une imagination vive, mit au jour un petit ouvrage, où notre Musique étoit presque aussi maltraitée que dans la Lettre de Monsieur Rousseau. Cet écrit n'excita ni guerres ni haine dans le tems où il parut; la Musique Françoise régnoit alors paisiblement sur nos organes assoupis; on regarda l'Abbé Raguenet comme un séditieux isolé, un conjuré sans complices, dont on n'avoit point de révolution à craindre.

Monsieur Rousseau a trouvé des lecteurs plus aguerris et plus disposés à l'entendre, et par conséquent plus de gens intéressés à le combattre. Mais nous ne pouvons nous dispenser de remarquer ici le jugement porté sur le livre de l'Abbé Raguenet par son Censeur Monsieur de Fontenelle, ce Philosophe si modéré et si pacifique, accoûtumé d'ailleurs à nos anciens Opéras dont il avoit les oreilles imbues et pénétrés, élevé enfin dans la Musique la plus Françoise et la moins ultramontaine; je crois, dit-il, que l'impression de cet ouvrage sera très-agréable au public, pourvu qu'il soit capable d'équité. Cinquante ans plus tard quel cri n'eut pas excité cette approbation? Le sage Fontenelle n'auroit pas eu l'imprudence ou le courage de parler ainsi de nos jours. Il n'étoit pas homme à se faire des ennemis pour des chansons. (D'Alembert, 1759, VI, p.392)

[Esta não é a primeira vez que se faltou com respeito à música francesa no mesmo lugar onde fica o seu império. No início deste século, o Abade Raguenet, escritor de uma imaginação viva, trouxe à luz uma pequena obra na qual nossa música foi praticamente tão maltratada como na Carta ${ }^{6}$ do Senhor Rousseau. Seu escrito não

6 Referência à Carta sobre a música francesa, de Jean-Jacques Rousseau. 
excitou nem guerras nem ódio no momento em que foi feito. A música francesa ainda reinou pacificamente sobre nossos órgãos adormecidos. Olhamos para o Abade Raguenet como um revoltado isolado, um conspirador sem cúmplices, do qual não devíamos temer nenhuma revolução.

O Senhor Rousseau encontrou entre os seus leitores mais experientes aqueles mais dispostos a ouvi-lo e, consequentemente, mais gente interessada nesse combate. Mas não podemos deixar de observar aqui o julgamento sobre o livro do Abade Raguenet pelo seu censor, o Senhor de Fontenelle, ${ }^{7}$ filósofo moderado e pacífico, acostumado também com as nossas antigas óperas, que se imbuiu de seus ouvidos e procurou, enfim, elevar a música a mais francesa e a menos ultramarina. "Eu creio", disse ele, "que a impressão deste livro será muito agradável ao público, desde que seja capaz de imparcialidade." Cinquenta anos mais tarde, qual grito não excitou essa aprovação? O sábio Fontenelle não teria tido a imprudência ou a coragem de dizer isso em nossos dias. Ele não era um homem de fazer inimigos por causa de canções.] (Tradução nossa)

Declaradamente contra Rousseau, D'Alembert manifestou a sua ideia de que a ópera francesa manteria sua primazia, pois meio século antes o Abade Raguenet havia tentado investir contra a própria música, e mesmo assim ela se manteve de acordo com os moldes do bom gosto, seguindo as regras das teorias imitativas, retirando seus modelos da natureza e da cultura clássica.

Enfin pour calmer les esprits, il a fallu de nouveau renvoyer les Bouffons, à peu près comme il fallut autrefois que Titus renvoyât

7 Bernard Le Bovier de Fontenelle (1657-1757), cientista francês, escritor e acadêmico. Estudou com os jesuítas no colégio de Rouan. Trouxe questões filosóficas para a ciência. Abandonou a filosofia de Descartes e abraçou a de Newton. Publicou, em 1686, suas Entretiens sur la pluralité des mondes [Conversas sobre a pluralidade dos mundos]. Era também literato, e seguiu esta carreira com uma tese sobre Corneille. Era a favor da cultura clássica (cf. Reill; Wilson, 2004, p.198). 
sa maitresse pour appaiser les Romains. Envain les Bouffonistes, réduits à la disette, ont demandé instamment qu'on ne les privât pas avec rigueur d'un amusement qu'on leur avoit laissé goûter. Ceux qui président à nos plaisirs (et qui n'en ont guere) ont été aussi inexorables à leurs plaintes, que les vieilles femmes le sont pour interdire l'amour aux jeunes.

On n'a voulu ni souffrir à l'Opéra la Musique Italienne, dont elle blessoit, disoit-on, la dignité, mais dont elle dévoiloit encore plus l'indigence; ni permettre à cette Musique de se faire entendre à ses malheureux partisans sur un théatre particulier, et uniquement destiné pour elle. A peinel'a-t-on soufferte dans quelques Concerts, dont la liberté n'est pas même trop assurée. Je ne sais pourtant si on a bien fait d'ôter cet objet de distraction ou de dispute à une nation vive et frivole, dont l'inquiétude a besoin d'aliment, qui même heureusement n'y est pas difficile, qui est satisfaite pourvu qu'elle parle, mais qui peut exercer sa langue sur des sujets plus sérieux, si on la lui lie sur ses plaisirs. On sait le mot du danseur Pylade à Auguste, qui vouloit prendre parti dans la dispute des Citoyens de Rome au sujet de ce danseur et de son concurrent Bathylle; Tu es un sot, dit le Comédien à l'Empereur, que ne les laisses-tu s'amuser de nos querelles? Quoi qu'il en soit, aujourd'hui que l'animosité est éteinte, les brochures oubliées, et les esprits adoucis, tandis que l'attention partagée des Parisiens oisifs est tournée vers des objets plus importans, et s'exerce sans fruit comme sans intérêt sur les affaires de l'Europe, seroit-il permis de faire un examen pacifique de notre querelle musicale? (D'Alembert, 1759, VIII, p.936)

[Enfim, para acalmar os espíritos, é necessário retornar aos bufões, um pouco como fez numa outra vez Tito, mandando sua amante apaziguar os romanos. Em vão os bufonistas, reduzidos à escassez, demandarão que não se os prive com rigor de um divertimento que fora deixado passar pelo seu próprio gosto. Para aqueles que presidem nossos prazeres (e que fizeram pouco deles) e eram inexoráveis em suas queixas, fizeram-no como fazem mulheres velhas ao tentar impedir o amor dos mais jovens. Seria o mesmo 
que desejar que a ópera não sofresse com a música italiana, pois que ela fere, dizem, a dignidade, revelando ainda mais a sua penúria, ou permitir a essa música se fazer ouvir por seus melhores partidários num teatro particular, e unicamente destinado para eles.

Tão logo se tenha sofrido em alguns concertos, vê-se que a liberdade não pode mesmo ser muito assegurada. Eu ainda não sei, portanto, se ela pode ser retirada como objeto de distração ou de disputa a uma nação viva e frívola, cuja inquietude e necessidade alimenta, mesmo que felizmente não seja difícil, uma satisfação da qual ela fala, mas que pode exercer sua língua nos temas mais sérios, ou se ligar sobre os seus prazeres. Conhecemos a palavra do dançarino Pílade a Augusto, que quis tomar partido na disputa junto aos cidadãos de Roma sobre o dançarino e seu concorrente Bathylle. "Tu és um idiota", disse o comediante ao imperador. "Por que não deixa que se divirtam com nossas querelas?" De qualquer maneira, hoje que esta animosidade está distante, as brochuras esquecidas, e os espíritos adocicados, enquanto a atenção que dividia os parisienses ociosos estava voltada para objetos mais importantes, e se exerce sem fruto e sem interesse sobre os negócios da Europa, será permitido fazer um exame pacífico de nossa querela musical?] (Tradução nossa)

D’Alembert tratou a questão das Querelas dos Bufões como algo sem importância. Acreditava que em nada a ópera italiana influenciaria os negócios de Estado, embora pudesse exercer fascínio sobre as pessoas que ele considerava as mais sérias, que era inevitável não sofrer influências do estilo dessa música, mas que a ópera francesa permaneceria como era.

Embora tivesse colocado a ópera francesa num patamar superior, como se ela fosse intocável, esse texto, como os outros da época, revelou uma incidência de música estrangeira num país que prezava muito o seu caráter nacional, a sua tradição, o rigoroso cumprimento das regras que orientavam as artes. $\mathrm{O}$ racionalismo caminhava junto com o subjetivismo, o qual posteriormente acabaria por suplantar aquele no contexto da música e das artes. 
As críticas a Rousseau continuaram, com digressões sobre as liberdades permitidas na França, que só poderiam terminar em degeneração. D'Alembret tratou os bufonistas como semelhantes aos republicanos e aos ateus, pois na verdade eles ameaçavam a estrutura monárquica da nação. Eram vistos como possuidores de uma visão curta, por quererem abraçar novos costumes e fazer-se presentes no Estado, mas para D'Alembert deveriam ser mantidos aqueles costumes que melhor regulavam os comportamentos, o gosto e a música.

A liberdade de pensamento nas artes degeneraria as regras, o que, na concepção de D'Alembert, era perigoso:

Je m'étonne d'abord que dans un siecle où tant de plumes se sont exercées sur la liberté du commerce, sur la liberté des mariages, sur la liberté de la presse, sur la liberté des toiles peintes, personne n'ait encore écrit sur La Liberté de la Musique. Être esclaves dans nos divertissemens, ce seroit, pour employer l'expression d'un Écrivain Philosophe, dégénérer non-seulement de la liberté, mais de la servitude même. "Vous avez la vue bien courte", répondent nos grands Politiques; "toutes les libertés se tiennent, et sont également dangereuses".

La liberté de la Musique suppose celle de sentir, la liberté de sentir entraîne celle de penser, la liberté de penser celle d'agir, et la liberté d'agir est la ruine des États. Conservons donc l'Opéra tel qu'il est, si nous avons envie de conserver le Royaume; et mettons un frein à la licence de chanter, si si nous ne voulons pas que celle de parler la suive bientôt. Voilà, comme disoit Pascal de je ne sai quel raisonnement d'Escobar, ce qui s'appelle argumenter en forme; ce n'est pas là discourir, c'est prouver.

On aura peine à le croire, mais il est exactement vrai que dans le Dictionnaire de certaines gens, Bouffoniste, Républicain, Frondeur, Athée, (j'oubliois Matérialiste) sont autant de termes synonimes. Leur logique profonde me rappelle cette leçon d'un Professeur de Philosophie. La Dioptrique est la science des propriétés des lunettes; les lunettes supposent les yeux; les yeux sont 
un des organes de nos sens; l'existence de nos sens suppose celle de Dieu, puisque c'est Dieu qui nous les a donnés; l'existence de Dieu est le fondement de la Religion Chrétienne; nous allons donc prouver la vérité de la Religion pour premiere leçon de Dioptrique. (D’Alembert, 1759, IX, p.396)

[Pergunto-me primeiramente como, num século em que tantas plumas se exerceram sobre a liberdade de comércio, a liberdade dos casamentos, a liberdade de imprensa, a liberdade das telas pintadas, as pessoas ainda escrevem sobre a liberdade da música. São escravas nos nossos divertimentos, se, empregando a expressão de um escritor filósofo, são degeneradoras não apenas da liberdade, mas da escravidão mesma. "O senhor tem a visão bem curta", observaram nossos grandes políticos. "Todas as liberdades que se asseguram são igualmente perigosas."

A liberdade da música supõe a esta sentir, e a liberdade de sentir resulta daquela de pensar, a liberdade de pensar daquela de agir, e a liberdade de agir é a ruína dos estados. Conservemos a ópera tal como ela é, se quisermos manter o reino, e coloquemos um freio à licença de cantar, se não quisermos mais falar nisso e seguir adiante. Aqui, como disse Pascal, eu não sei qual o raciocínio de Escobar, chamado aqui de "argumento em forma". Isso não é discursar, é provar.

Será difícil acreditar, mas é verdadeiro que no Dicionário ${ }^{8}$ de certas pessoas, bufonistas, republicanos, fundibulários, ${ }^{9}$ ateus (esqueci os materialistas), são todos termos sinônimos. Sua lógica profunda me lembra esta lição de um professor de filosofia: "A dioptria é a ciência das propriedades dos óculos; os óculos supõem os olhos; os olhos são um dos órgãos dos sentidos; a existência de

8 Referência ao Dicionário de Música, de Jean-Jacques Rousseau, publicado posteriormente, em 1768.

9 Fundibulário: aquele que combate com funda; hoje não há mais fundibulários, mas a palavra aparece nos livros de História. Funda: arma de arremesso constituída por uma correia dobrada em cujo centro é colocado o objeto que se deseja lançar; estilingue; atiradeira (cf. Borba, 2012, p.654-5). 
nossos sentidos supõe aquela de Deus, uma vez que foi Deus que a deu a nós; a existência de Deus é o fundamento da religião cristã; por isso devemos provar a verdade da religião para a primeira lição de dioptria.] (Tradução nossa)

Fez ainda outras críticas à música italiana e a seus partidários. Declarou que ela não afetaria a tradição da música francesa, nem traria melhoria para as pessoas. A ópera francesa, assim como o teatro francês, tinha também a função de servir de exemplo no que se referia aos costumes, à maneira de se comportar e agir em sociedade, visando a melhoria de seus cidadãos, embora o seu modelo de cidadão fosse o nobre. A música italiana, pelo que se deduz do texto de D'Alembert, não poderia promover esse aperfeiçoamento à sociedade francesa, já que, para o gosto dos franceses, sua música era inferior à dos franceses.

La Musique Italienne, ajoutent-ils, nous dégoûteroit de la Françoise. Où est l'inconvénient, si la Musique Italienne est préférable? C'est comme si on eût défendu à Corneille de composer ses Pieces, sous prétexte qu'elles devoient faire oublier celles de Hardi et de Jodelle. Mais on fait plus d'honneur à la Musique Italienne qu'elle ne mérite; après l'avoir entendue pendant plus d'un an, il s'en faut bien que nous soyons revenus de la nôtre. On court à l'Opéra les Vendredis comme à l'ordinaire; et les Bouffonistes qui en avoient annoncé la désertion, se sont trompés dans leurs prophéties.

Ces Enthousiastes ont jugé de l'impression du vulgaire par celle qu'ils éprouvoient. Ils ont été dans la même erreur que certains Écrivains de nos jours, qui nous parlent sans cesse des progrès de la nation dans ce qu'ils appellent l'esprit Philosophique, et qui s'imaginent avoir contribué par leurs ouvrages à répandre cet esprit jusque dans le peuple. S'établit-il dans un fauxbourg quelque prétendu faiseur de miracles? Le peuple y court en foule, et l'esprit Philosophique est pris pour dupe.

Je me représente les Philosophes vrais ou prétendus, qui ont quelque réforme à faire ou à prêcher, comme étant sur le bord d'un 
fleuve très-rapide qu'ils se proposent de franchir; ils assemblent leur siecle sur le bord du fleuve, le haranguent, et l'exhortent à les imiter. Ils se jettent ensuite dans le fleuve, et à travers une grêle de traits, ils le passent à la nage, ne doutant point que leur siecle ne les suive.

A peine ont-ils passé, qu'ils se retournent, et voient leur siecle à l'autre bord, qui les regarde, qui se moque d'eux, et qui s'enva; c'est la Fable du Berger et de son troupeau. Ne jugeons donc pas de l'effet de la Musique Italienne sur le commun des spectateurs, par celui qu'elle a produit sur un petit nombre. Son futur empire, fût-il aussi infaillible qu'il est douteux, aura besoin de tems pour s'établir. Toute Musique, pour peu qu'elle soit nouvelle, demande de l'habitude pour être goûtée par le vulgaire; c'est pourquoi si l'Opéra François a quelque décadence à craindre, elle n'arrivera que peu à peu, et il pourra survivre encore à la génération qui le regrette. Qu'elle jouisse en paix de ses tranquilles plaisirs; mais qu'elle ne prétende point régler ceux de la génération suivante. (D'Alembert, 1759, XI, p.399)

[A música italiana, dizem eles, repugna a nossa francesa. Onde está o inconveniente se a música italiana é preferível? É como se estivéssemos defendendo Corneille de compor suas peças, sob o pretexto de que elas deveriam fazer esquecer aquelas de Hardi e de Jodelle. Mas se fizeram mais honras à música italiana do que ela merece. Depois de ouvi-la por mais de um ano, é preciso fazer muito para voltarmos à nossa. Corremos para a Ópera às sextas-feiras, como é de ordinário, e os bufonistas que tinham anunciado a deserção estavam enganados em suas profecias. Esses entusiastas são julgados pela impressão vulgar daquilo que sentem.

Eles cometem o mesmo erro que certos escritores de nossos dias, que nos falam incessantemente dos progressos da nação, daquilo que eles chamam de espírito filosófico, e imaginam contribuir, por meio das suas obras, para difundir esse espírito nas pessoas. Ele se estabeleceu em algum subúrbio e pretendeu fazer milagres? O povo e a corte em multidão, o espírito filosófico é o primeiro a se enganar. 
Eu represento os filósofos verdadeiros ou pretensiosos, que têm alguma reforma a fazer ou a pregar, como estar à beira de um rio muito rápido que se quer atravessar. Eles montam em seu século na beira do rio, na arenga, e exortam-nos a imitá-los. Eles fluem para o rio, e através de uma chuva de traços passam a nado, não duvidando de que seu século os seguiu.

Mal eles passam, quando se voltam para trás, veem seu século do outro lado, que zomba deles, que os invade. Esta é a fábula do pastor e seu rebanho. Portanto, não julguemos os efeitos da música italiana sobre o comum dos espectadores, para quem ela produziu pouco. Seu futuro império, tanto infalível como duvidoso, precisa de tempo para se estabelecer. Toda música, por pouco que seja nova, demanda costume para ser apreciada pelo vulgar. Por que, se a ópera francesa teme alguma decadência, ela chegará pouco a pouco, e poderá sobreviver à geração que está por vir. Que ela goze em paz os seus tranquilos prazeres, mas que não tenha a pretensão de regrar esses pontos na geração seguinte.] (Tradução nossa)

Era notória a ideia, segundo o autor, de que a hierarquia social francesa se manteria sempre como era e de que a ópera representaria a classe dominante. No fragmento de texto anterior, o tempo de duração do poderio aristocrático pôde ser subentendido quando D'Alembert disse que a decadência da ópera francesa demoraria a chegar e que a força estrangeira, como era o caso da influência italiana, seria insuficiente para derrubar os costumes estabelecidos. Manter a ópera como era significava que as regras não mudariam, que o poder permaneceria como era, que a imitação se manteria como sempre foi.

Ter bom gosto significava seguir as regras. D'Alembert se posicionou também com relação a essa ideia. Questionou aceitar-se uma forma de fazer arte, como a ópera bufa italiana, que seria, na sua concepção e na dos partidários da opera seria, trocar o melhor pelo pior, já que os italianos, a seu ver, não seguiam as regras clássicas. Fez ainda considerações sobre o fato de o gosto francês ser importado por outras nações, mais um motivo para que os fran- 
ceses não aceitassem o gosto italiano, e disse que era este povo que conhecia de verdade o caráter do teatro, da comédia, da tragédia e da ópera. Salientou as diferenças entre a ária e o recitativo, que a seu ver os italianos faziam da mesma maneira, mas os franceses sabiam diferenciar. O reconhecimento racional dos modelos da natureza a partir das regras, na ópera, atingia o coração. Era fornecido um quadro, como na pintura, e desenvolvido o percurso das paixões. A sua melhor expressão era a tragédia, quadro dos sentimentos humanos, e por isso ela tornou-se o modelo para a ópera. Para os franceses, cada coisa tinha seu lugar específico, e era isso que demarcava a variedade no gosto. Se na ópera se cantava, na tragédia se declamava, e para D'Alembert isso não estava claro para os italianos. Tudo parecia homogêneo, mais um motivo para não aceitar o gosto desse povo para os espetáculos de música. Mesmo a variedade deveria ter equilíbrio, para não se perder pelo excesso e o gosto não ser devidamente apreciado.

Ainda quanto ao gosto, D'Alembert escreveu:

Cependant seroit-il juste de régler absolument notre goût, quant aux spectacles en Musique, sur l'opinion et l'exemple des étrangers, eux qui dans tout le reste sont accoutumés à prendre le goût François pour le modele du leur? Quelque général que soit leur suffrage en faveur de l'Opéra Italien, s'ensuit-il que nous ferions bien de les imiter? La forme de cet Opéra, il faut en convenir, le rend uniforme et ennuyeux; celle du nôtre est sans comparaison plus variée et plus agréable. Nous avons, ce me semble, mieux connu qu'aucun autre peuple le vrai caractere de chaque Théatre; chez nous la Comédie est le spectacle de l' esprit, la Tragédie celui de l'ame, l'Opéra celui des sens; voilà tout ce qu'il est et tout ce qu'il peut être.

Où la vraisemblance n'est pas, l'intérêt ne sauroit s'y trouver, au moins l'intérêt soutenu; car l'intérêt de la Scene est fondé sur l'illusion, et l'illusion est bannie d'un Théatre où un coup de baguette transporte en un moment le spectateur d'une extrémité de la terre à l'autre, et où les Acteurs chantent au lieu de parler. 
Ce n'est pas que la Musique bien faite d'une Scene touchante ne nous arrache quelquefois des larmes, ni que je veuille renouveller l'objection triviale contre les Tragédies en musique, que les Héros y meurent en chantant; laissons au vulgaire ce préjugé ridicule, de croire que la Musique ne soit propre qu'à exprimer la gaieté; l'expérience nous prouve tous les jours qu'elle n'est pas moins susceptible d'une expression tendre et douloureuse.

Mais si la Musique touchante fait couler nos pleurs, c'est toujours en allant au coeur par les sens; elle differe en cela de la Tragédie déclamée, ou pour parler plus juste, de la Tragédie parlée, qui va au coeur par la peinture et le développement des passions. L'Opéra est donc le spectacle des sens, et ne sauroit être autre chose. Or si les plaisirs des sens, comme nous l'éprouvons tous les jours, s'émoussent quand ils sont trop continus, s'ils veulent de la varieté et de l'interruption pour être goûtés sans fatigue, il s'ensuit que dans ce genre de spectacle le plaisir ne peut entrer dans notre ame par trop de sens à la fois; qu'on ne sauroit, pour ainsi dire, lui laisser trop de portes ouvertes, y mettre trop de de diversité; et qu'un Opéra qui réunit comme le nôtre les machines, les choeurs, le chant et la danse, est préférable à l'Opéra Italien qui se borne au spectacle et au chant. On prétend, je le sai, que les Opéras Italiens ont un avantage, en ce qu'ils peuvent être déclamés comme chantés, ce qui n'auroit pas lieu dans les nôtres.

Supposé le fait vrai, tout ce qu'on en peut conclure, c'est qu'il faut chanter nos Opéras et déclamer nos Tragédies. Mais ce prétendu avantage des Tragédies Italiennes, d'être également propres au chant ou à la déclamation, rend à mes yeux leur mérite bien suspect. C'est n'avoir point de caractere que d'en pouvoir si facilement changer; et je ne sai ce qu'on doit penser d'un genre de pieces, auquel la forme de la représentation est indifférente. J'accorderai pourtant, si l'on veut, que le meilleur Opéra de Quinaut déclamé, fera moins de plaisir que le meilleur Opéra de Métastase déclamé de même; j'accorderai encore que la meilleure Tragédie de Racine mise en musique, nous plaira moins que la meilleure Tragédie chantée de Metastase; mais qu'on joue à la suite l'une de l'autre une 
Tragédie de Racine et une de Metastase, et qu'on exécute de même successivement un Opéra de Metastase, et un Opéra de Quinault mis en bonne Musique: et malgré toute l'estime que mérite le Poëte Italien, je ne doute pas que l'avantage du parallele ne demeure aux deux Poëtes François. (D’Alembert, 1759, XIII, p.403)

[No entanto, seria justo regrar absolutamente nosso gosto, quanto aos espetáculos em música, pela opinião e pelo exemplo dos estrangeiros, enquanto todo o resto está acostumado a tomar o gosto francês como modelo para o seu? Alguém daria seu voto em favor da ópera italiana, resultando que nos faria bem em imitá-la? A forma dessa ópera, reconhecidamente, a torna uniforme e enfadonha. A nossa é, sem comparação, mais variada e agradável. Nós temos, parece-me, melhor conhecimento do que qualquer outro povo sobre o verdadeiro caráter de cada teatro. Conosco a comédia é o espetáculo do espírito, a tragédia, o da alma, a ópera, o dos sentidos. "Tudo o que ele é, é tudo o que pode ser."

Naquilo onde a verossimilhança não está, não há o interesse, ao menos o interesse apoiado, porque o interesse da cena é fundamentado sobre a ilusão, ${ }^{10}$ e a ilusão é banida de um teatro em que, por um golpe de varinha mágica, o espectador é transportado, por um momento, de uma extremidade da terra a outra, em que os atores cantam, ao invés de falarem. Não que esta música bem feita de uma cena tocante não nos comova até as lágrimas, nem quero relembrar a objeção trivial contra as tragédias em música nas quais os heróis morrem cantando. Deixemos ao vulgar esse prejuízo ridículo, crer que a música seja própria para exprimir alegria. A experiência nos prova todos os dias que ela não é menos suscetível a uma expressão terna e dolorosa.

Mas se a música faz fluir nossos prantos, é sempre do coração para os sentidos. Ela difere daquela da tragédia declamada, ou,

10 A ilusão era consequência da verossimilhança. Todas as regras imitativas objetivavam que a promoção da ilusão pudesse ocorrer de maneira satisfatória. Sua realização era a satisfação do ouvinte, porque reconhecida como expressão da cultura clássica. 
para falar mais exatamente, da tragédia falada, que vai do coração para a pintura e move as paixões. A ópera é então o espetáculo dos sentidos, e não saberá ser outra coisa. $\mathrm{Ou}$, se os prazeres dos sentidos, como sentimos todos os dias, se aborrecem quando são muito contínuos, se querem a variedade e a interrupção, por serem degustadas sem fadiga, segue-se que nesse gênero de espetáculo o prazer pode entrar em nossa alma por muitas direções ao mesmo tempo. Não podemos, por assim dizer, deixar as portas abertas e colocar muita diversidade. Uma ópera como a nossa, que reúne as máquinas, os coros, o canto e a dança, é preferível à ópera italiana, que se limita ao espetáculo e ao canto. Pretende-se, eu sei, que as óperas italianas sejam uma vantagem, que podem ser tanto declamadas como cantadas, o que não tem lugar nas nossas.

Suponha-se o fato verdadeiro, tudo o que se pode concluir, aquilo que se deve cantar em nossas óperas e declamar em nossas tragédias. Mas esta pretensa vantagem das tragédias italianas, de serem igualmente próprias ao canto ou à declamação, tem a meus olhos um mérito bem suspeito. Isto de não ter nenhum caráter é para poder facilmente mudar, e eu não sei o que se deve pensar de um gênero de peças a que qualquer forma de representação é indiferente. Estou de acordo, portanto, se alguém quiser, que a melhor ópera de Quinault, declamada, será menos prazerosa que a melhor ópera de Metastásio, bem declamada. Estou ainda de acordo que a melhor tragédia em música de Racine nos emociona menos que a melhor tragédia cantada de Metastásio. Mas toquemos num conjunto uma e outra das tragédias de Racine e uma de Metastásio, e que se execute do mesmo modo e sucessivamente uma ópera de Metastásio, e uma ópera de Quinault com boa música, e malgrado toda a estima que merece o poeta italiano, não duvido de que a vantagem do paralelo não permaneça do lado dos dois poetas franceses.] (Tradução nossa)

O gosto estava na ilusão da cena, na capacidade racional e regrada de comover, de tocar as paixões e provocar o terror e a compaixão, como ocorria na tragédia, pelas situações que guardavam 
verossimilhança com a ação promulgada no texto do libreto da ópera. A experiência trágica da representação produzia sentimentos mais profundos e intensos do que a alegria, que era sempre superficial, e por isso a música era considerada mais eficaz na produção trágica da ópera do que na cômica, e seria preferível a esta. Somente através do trágico, dos sentimentos profundos, vivenciados intensamente, é que se poderia refletir sobre os costumes e o comportamento em sociedade. A ópera bufa não teria espaço para isso e não seria melhor do que a francesa, porque mobilizaria sentimentos superficiais, sem regras.

D’Alembert ainda declarou que a melhor música italiana não era aquela que havia caído no gosto dos franceses e que seria injusto julgá-la pelo que tinha de pior - no caso, a ópera cômica -, que se esta devesse trazer alguma reflexão sobre possíveis mudanças obrigatórias na opera seria francesa, que então a música sofresse essas mudanças, e não a língua francesa. Isso demonstrou que o papel da música, nessa concepção, era o de ser subserviente à linguagem verbal, e não o inverso - mesmo porque ela havia sido atacada por Rousseau, que a considerava inadequada para o canto, o que D’Alembert também criticou, ao dizer que, mantendo a língua, o caráter da nação seria preservado. O significado da música só se manteria se o significado da língua fosse mantido.

Sobre essa questão, D’Alembert (1759) declarou:

Les Italiens ont donc de fort mauvaise Musique, et même en très grande quantité. Mais juger la Musique Italienne sur ce qu'elle a de foible ou de défectueux, c'est juger notre école de peinture par nos tableaux d'enseigne, ou notre Théatre par les pieces de Pradon. Et où en serions-nous, si les Italiens vouloient apprétier la Musique françoise par celle que nous reconnoissons nous-mêmes pour détestable? C'est d'après ce que les deux Musiques ont de meilleur qu'il faut les comparer: et quand on fera cette comparaison avec un peu de lumieres, de sentiment, et de bonne foi, quand on aura mis la richesse, la chaleur, et la variété des Italiens, à côté de notre monotonie, de notre froideur et de notre indigence, pourra-t-on ne 
pas penser avec toute l'Europe, que la Musique Italienne est une langue dont nous n'avons pas seulement l'alphabeth?

Tout se réduit donc à savoir, si nous devons ou plutôt si nous pouvons adopter cette Musique, si notre Opéra pourra s'y prêter, et jusqu'à quel point il en sera susceptible. Mais, dira-t-on, ne seroit-il pas plus court de donner à l'Opéra Italien la forme du nôtre? Oui, si on pouvoit engager les Italiens à changer leur Opéra, et les François à abandonner leur langue; et c'est ce qui ne paroît pas facile. J'ai meilleure opinion de la docilité de nos Musiciens; la plupart semblent assez peu attachés à la Musique ancienne; cette disposition paroît surtout dans les jeunes Artistes, qui sont ceux dont on doit le plus espérer; l'impénitence finale est le partage des autres.

Déja même sur le Théatre de l'Opéra, sur ce Théatre si attaché à ses anciens usages, on a hazardé des nouveautés; nous y avons vu un Opéra Gascon. C'est un pas vers des changemens plus nécessaires et plus agréables; à la vérité le pas est un peu en arriere; car il ne s'agit point, comme on l'a fait dans cet Opéra, de garder notre Musique et de changer notre langue; il s'agit de garder notre langue, et de changer, si nous pouvons, notre Musique. Mais enfin cette innovation, quelle qu'elle soit, prouve que nous osons risquer encore, et que parmi nous la superstition de l'Opéra n'est pas tout-à-fait incurable. (XVII, p.417)

[Os italianos têm uma música muito ruim, e mesmo em grande quantidade. Mas julgar a música italiana pelo que ela tem de fraco ou de defeituoso é como julgar nossa escola de pintura pelos quadros ensinados, ou nosso teatro pelas peças de Pradon. ${ }^{11}$ E onde estaríamos se os italianos desejassem apreciar a música francesa por aquela que nós mesmos reconhecemos como detestável? Isso

11 Jacques Pradon (1632-1698), escritor que obteve certo sucesso à época de Pierre Corneille, de quem recebeu ajuda. Foi execrado pela crítica por não seguir a regra das três unidades, ou seja, de ação, tempo e lugar, exigida pela teoria da verossimilhança. Foi suplantado pelo sucesso e pela melhor aceitação das tragédias de Racine. 
depois que as duas músicas tiverem feito o melhor que for preciso para compará-las, e quando se fizer essa comparação com um pouco de luminosidade, de sentimento e de boa fé, quando colocarmos mais a riqueza, o calor e a variedade dos italianos ao lado da nossa monotonia, da nossa frieza e da nossa indigência, talvez não se pense com toda a Europa que a música italiana é uma linguagem que não tem nem unicamente o alfabeto?

Tudo se reduz a saber se devemos, ou melhor, se podemos adotar essa música, se nossa ópera será capaz de se prestar a ela, e até que ponto lhe será suscetível. Mas, dizemos, não será mais fácil dar à ópera italiana a forma da nossa? Sim, se pudermos fazer os italianos cantarem sua ópera, e os franceses, abandonarem a sua língua, e é isto que não parece fácil. Possuo melhor opinião quanto à docilidade de nossos músicos. A maior parte parece bastante ligada à música antiga. Esta disposição aparece principalmente nos jovens artistas, que são aqueles de quem devemos esperar mais. A impenitência final é compartilhada pelos outros.

Até mesmo no teatro de ópera, nesse teatro tão apegado a seus antigos usos, nos aventuramos às novidades, como temos visto na ópera Gascon. É um passo para as mudanças mais necessárias e mais agradáveis. Na verdade, é um passo que se volta um pouco para trás, porque não há dúvida sobre o que fazer e como fazer nesta ópera, guardar nossa música e mudar nossa língua. Trata-se de não mudar nossa língua, e de mudar, se pudermos, nossa música. Mas, enfim, essa inovação, que ela seja, então, prova de que ousamos ainda arriscar, e de que entre nós a superstição da ópera não é de fato de todo incurável.] (Tradução nossa)

Essas questões demonstraram, mais uma vez, que a lógica racional exigia que a música tivesse as mesmas características da linguagem verbal, que satisfizesse ao raciocínio, que na ópera conduzisse a ação, do mesmo modo que a linearidade narrativa de um texto literário era capaz de conduzir a ação numa tragédia teatral. A união de música e poesia demonstrava a relação de opostos, que caminhava, segundo as concepções de época, por caminhos dife- 
rentes. Razão e passionalidade, língua e música, aquela orientando e controlando esta, numa tarefa difícil de conciliar.

Todas essas características haviam tornado os libretos de ópera compreensíveis apenas a um público estrito, que conhecia e cultivava com requinte a história e a mitologia clássicas. Os heróis da mitologia grega e latina ou mesmo tomados da história antiga, quando transformados em personagens de ópera, eram representados em meio a conflitos estereotipados, como o conflito entre a honra e o amor, temas caros à mentalidade aristocrática, já que a honra era uma característica bastante importante para a sociedade francesa. Pelo fato de a estrutura da ópera ter sido equivalente à estrutura hierárquica da sociedade, muitas vezes o seu principal herói era a personificação do monarca, com muitas alusões à figura do soberano. A ópera imitava não somente os temas clássicos, seguindo regras rígidas ao fazê-lo, mas também imitava e representava a sociedade da qual fazia parte. A música deveria servir àquele que estava no ápice da hierarquia social, o monarca. Assim, a música da corte era organizada, hierarquizada, sujeita ao luxo que cercava o rei, subserviente a um regulamento e a um rigoroso cerimonial.

Por sua vez, as querelas revelaram algo que já ocorria anteriormente a elas: a falta de controle da aristocracia com relação às concessões feitas à classe burguesa emergente, devido a uma perda econômica e ao enfraquecimento de seu poderio. A nobreza, frágil economicamente, permitiu o acesso dessa classe nos seus eventos, já que se beneficiava de sua prosperidade econômica. A burguesia, ascendente economicamente e desejosa de fazer parte do convívio da corte, acabou por imitar a aristocracia em certos domínios, de acordo com a sua própria mentalidade e o seu estilo de vida. Imitou as festas e cerimônias aristocráticas, pois estas cumpriam uma função proeminente na sociedade. A música acompanhava as ocasiões as mais diversas, como recepções solenes, noivados, casamentos, ainda mais quando a monarquia entrou em declínio, a partir dos anos de 1750. A classe burguesa desenvolveu assim elementos de uma vida musical autônoma e paralela à vida aristocrática, carregando consigo elementos da vida musical da corte e dos salões aristocráticos. 
Embora a ópera fosse uma arte monárquica, que glorificava os soberanos, o desenvolvimento da música entre a burguesia trouxe a aceitação da ópera bufa italiana. Por essa via, ela ingressou nos meios aristocráticos, recebendo aceitações e reservas. As diferenças de opinião acabaram por desencadear as "querelas" entre França e Itália na segunda metade do século.

A influência burguesa na estrutura da classe aristocrática, por receber e permitir o acesso dessa classe em seu convívio, afrouxou também a severidade de parte da corte que, por conta dela, aceitou modificações na ópera.

Frequente nas salas de concertos aristocráticas, a ópera em geral não era compreendida pelos que a assistiam. Embora essas pessoas gozassem de considerável prosperidade econômica, não sabiam identificar a cultura clássica nas produções operísticas a que assistiam, assim como nas artes em geral. Isso já havia sido percebido na década de 1720, o que, entre muitos outros motivos mais importantes, levou Jean-Baptiste Dubos a escrever suas Reflexões críticas sobre a poesia e a pintura e, na década de 1740, incentivou Charles Batteux a produzir As belas-artes reduzidas a um mesmo princípio, pois a cultura clássica começava a ser ignorada e esquecida pelo novo público que frequentava as salas de concerto.

Essa mistura e o convívio entre as duas hierarquias sociais produziram mudanças na maneira de compor ópera, além da grande incidência de música instrumental. Críticas foram feitas por aqueles que defendiam a tradição clássica na composição das óperas, na sua composição ou na sua execução.

Longe de ser tão instruído e refinado quanto o público aristocrático, o público burguês estava igualmente longe de possuir uma cultura musical comparável à daquele. Apesar do seu interesse pela música, era frequente que esse novo público manifestasse um gosto bem medíocre ou mesmo bastante vulgar. Era característica da mentalidade desse público a opinião segundo a qual a música tinha o poder de aliviar o peso dos esforços e do cansaço de um dia dedicado (pelo burguês) a tratar de negócios, a ocupar-se com núme- 
ros e contas. Também com frequência, as motivações do público musical parisiense da primeira metade do século XVIII eram de natureza mais social que artística: por essa época, era comum apreciar-se a música mais pelo que ela podia acrescentar à vida mundana e à moda, assim como a uma educação de elite - objetivo que a burguesia se esforçava por alcançar -, do que por seu valor artístico próprio. (Supicic, 1997, p.412)

Devido ao status que promovia, a opera seria começou a ser executada em ambientes públicos e sua cultura complexa, destinada à corte, foi adaptada para atingir a classe média. Essa transformação social trouxe como consequência o esquecimento e até mesmo o desprezo da teoria imitativa para as artes, que começou a ser menos frequente no decorrer do século XVIII.

A falta de instrução e de refinamento da classe burguesa trouxe outras exigências quanto ao que era esperado da ópera. Como a sua vantagem econômica poderia promover o seu gosto e a sua satisfação, os compositores se viram no dever de seduzir essa plateia. Para isso, burlaram os requisitos das regras tradicionais, introduzindo modificações em suas obras líricas, ao sabor da escolha de cada representação operística, variando o prazer dos ouvintes, fazendo-lhe concessões, aceitando soluções diferentes, devido ao compromisso econômico. Dentre as concessões feitas a esse público burguês incluía-se o corte de trechos de óperas para que se tornassem mais inteligíveis e mais acessíveis a esse público e mais aceitas por ele. Com isso, as óperas começaram aos poucos a ter sua estrutura alterada, a exibir elementos de comédia misturados com os de tragédia, e a ópera bufa italiana, ao chegar, passou a ter maior aceitação, por ser mais compreensível para esse público, embora causasse estranheza ao público aristocrático.

A ópera, como fenômeno social, teve na ópera cômica a apreciação e o advento da classe média. Ela refletia o gosto burguês e pequeno burguês, e era grande o seu contraste com relação à opera seria da corte, já que esta extraía seus temas heroicos da mitologia greco-latina ou da história antiga, que defendiam um caráter mu- 
sical mais refinado, com um texto mais elaborado. Já os temas da ópera cômica se dirigiam às classes médias. Muitas vezes ridicularizavam a nobreza e até mesmo a opera seria. Todos podiam participar, sem restrições, de uma audiência das representações de ópera cômica, ao contrário da opera seria, que impunha restrições para ser assistida - por exemplo, o uso de roupas consideradas adequadas.

Para aqueles que queriam atacar a realeza e seu ideário aristocrático, a ópera bufa foi bastante oportuna e ganhou a adesão dos enciclopedistas. Os filósofos franceses do Iluminismo enxergaram essa música como um fenômeno de importância social, difícil de ser ser explicado pelos moldes do racionalismo da época, apesar da corrente apreciada por muitos teóricos e filósofos segundo a qual a música vocal, ou opera seria, satisfazia a exigência racional e a nacional.

Entre os enciclopedistas, a música recebeu importante espaço nas publicações da Encyclopédie, retirando-se do isolamento em que se encontrava até então. A ópera, por sua vez, foi o gênero que mais sucesso obteve junto ao público. A frequência de suas apresentações e representações permitiu o constante contato entre poetas e músicos. Isso também fez que se passasse a considerar o estatuto do músico executante, até então tratado como mero artesão. A ópera, diante do seu sucesso na sociedade, não constituiu apenas mais um divertimento para as classes superiores, mas configurou-se como palco para um cenário de lutas entre várias correntes filosóficas e estéticas, com gostos distintos, ocupando espaço cada vez maior nas discussões.

A cultura aristocrática reinante começava a ter seu gosto alterado e esforçava-se por manter sua visão dominante sobre as artes e a ópera, em comparação com as exigências da classe burguesa. $\mathrm{O}$ seu descontentamento diante dessa alteração foi manifestado em escritos sobre música, através de comparações, paralelos, polêmicas e querelas. Por conta disso, também surgiram os julgamentos de uma música por si mesma e de um compositor em especial, julgamento que anteriormente centrava-se na maneira de imitar, se era ou não correta, se estava ou não de acordo com as regras. Já a ópera cômica satisfazia ao gosto desse novo público, da classe burguesa 
em expansão, do qual não eram exigidos o conhecimento e o gosto necessários para apreciar a complexidade da ópera da corte.

Em seu período áureo, a primazia e a ênfase da natureza da música estavam na razão. Depois, com o declínio da aristocracia e o livre curso das ideias iluministas francesas, a ênfase recaiu sobre a música em si mesma. O caráter mais racional da música perdia força no julgamento das obras musicais.

Anteriormente à decadência da corte, as hierarquias sociais mostravam-se bem distintas, e a música, nas suas representações, espelhava, com o uso das regras das teorias imitativas, esses caracteres nas personagens da ópera. Os contrastes sociais também se apresentavam na própria música, como a binaridade ária/recitativo, melodia/baixo contínuo, harmonia/polifonia.

A opera seria também deu mostras de um caráter ritual na música de corte, o que explicou sua extraordinária importância nesse meio, mas não apenas isso: ela participou da ordem cerimonial vigente e também se alimentou dela, trazendo para si e para o seu estilo características dessa ordem na composição do seu caráter. Daí a ópera francesa ter sido uma representação do próprio caráter nacional francês. Ela espelhava o caráter da própria realeza, e por isso mesmo foi atacada no movimento das querelas, não só no que se refere ao estilo musical, mas também ao seu significado aristocrático na sociedade.

\section{Uma estética da expressão: André Morellet e a expressão em música}

O declínio da aristocracia, a ascensão burguesa e o maior convívio entre as duas classes, a partir da segunda metade do século XVIII, na França, produziram transformações no gosto musical, mas não explicaram de fato os significados e o que era imitar na música. Até então, imitar significava seguir regras, de acordo com uma concepção racionalista de natureza e com formas poéticas clássicas, como pressupostos para dar valor e avaliar a música e as artes. As querelas mostraram mais a tentativa de manter essas regras no fazer musical do que o seu significado. 
Na concepção racional, a música imitava a natureza, com o suporte da linguagem verbal, demarcada pelo texto literário. A poesia era universal e expressava a razão, através da qual as paixões humanas seriam atingidas. Com a associação da natureza aos sentimentos, a música abarcou significados subjetivos, o que posteriormente faria que fosse tomada como a linguagem dos sentimentos. Com essa nova concepção, a música instrumental ganhou maior autonomia, por corresponder às inflexões do coração, ao mesmo tempo que ocorria um afrouxamento no dispositivo imitativo na música vocal usado como regra, fosse devido ao esquecimento de sua formulação no domínio da música, com o passar do tempo, fosse porque uma espécie de linguagem dos sentimentos não precisaria mais satisfazer às exigências da razão através dessas regras.

A teoria da imitação foi perdendo sua eficácia, considerada limitada na música. Muitas vezes, a tentativa de imitar se restringia aos fenômenos da natureza, e seu papel subalterno à linguagem das palavras, restrito a acompanhamento, foi sendo questionado, devido ao aumento da quantidade de música instrumental produzida. Esta música, para Dubos e Batteux, apresentava problemas de classificação, era considerada sem significado se desprovida do escopo verbal, mas, com o aumento da sua produção, a sua restrição como acompanhamento aos poucos foi diminuindo, emergindo perguntas e reflexões sobre sua capacidade de imitar, se imitar seria mesmo o seu dever, se deveria produzir algum sentido. Mediante esse quadro, questionamentos sobre a produção de sentido musical começaram a aparecer. André Morellet (1727-1819), economista e filósofo ligado ao Iluminismo, indagou sobre a teoria da imitação e usou o termo "imitação" como sinônimo de "expressão". Dele temos a obra De l'expression en musique et de l'imitation dans les artes [Da expressão em música e da imitação nas artes], de 1771, em que teceu comparações entre a música vocal e a instrumental, sobre os seus limites e como esses dois gêneros poderiam imitar.

Morellet pesquisou e discutiu na sua obra os meios que a música utilizou para realizar a imitação. Além disso, distinguiu os tipos de objetos que a música empregou na imitação, partindo do princípio 
de que ela se configurava como uma linguagem, já que fazia uso do mesmo órgão produtor das palavras. A música vocal e a produção de linguagem através da fala utilizavam o mesmo canal, e Morelet fez uma analogia entre elas, pois as duas, na sua concepção, afetavam os mesmos sentidos.

Assim como a pintura imitava e representava na tela objetos que realmente existiam, a música imitava as paixões e as representava em suas composições. As palavras imitavam, como na pintura, os ruídos e as figuras da natureza, procurando produzir seus efeitos na música. A busca pela imitação ou representação era feita através de analogias que permitissem reconhecer seus objetos. O órgão vocal era o meio que possibilitava a execução da fala e da música e, por se organizar como a fala, a música era uma linguagem.

Os objetos imitados ou "pintados" eram potencializados pela música vocal, dando força ao discurso, por isso a poesia tinha lugar privilegiado. Prova disso era o seu uso, e por tanto tempo, nas línguas das mais diversas nações. A música poderia escolher os objetos que gostaria de representar, e pela voz e pelos instrumentos musicais ela poderia sugerir representações sonoras, por meio de analogias com os objetos imitados.

Morellet observou e reconheceu que na música poderiam existir imitações aproximadas dos objetos, mas os objetos contemplados poderiam não ser exatamente os que estavam na música, deixando margem para uma possível arbitrariedade em suas associações. As analogias com os objetos não significavam assemelhar-se a eles, e na verdade muitas vezes um era tomado pelo outro.

Devido à arbitrariedade na imitação dos objetos, por meio de associações, a imitação poderia nem ocorrer realmente, e parte da associação ficaria a cargo da imaginação do ouvinte, que completaria em sua cabeça essas relações da música com os objetos contemplados.

Para o autor, as relações entre música e língua também possuíam um limite, insuficiências e imprecisões, pois trabalhavam apenas com aproximações. Porém, como a música utilizava a teoria da imitação, cuja prerrogativa era a verossimilhança, não se ocu- 
pando então da verdade, mas do que parecia ser verdade, reconhecia também que na natureza havia imperfeições e que o objetivo da imitação era tornar perfeitos os objetos imperfeitos nela encontrados, corrigir suas falhas, a fim de se mostrarem melhores do que a própria verdade e serem agradáveis aos espíritos. O prazer estava em reconhecer por detrás da perfeição objetos dos quais o modelo estava na natureza. E, como a música tinha limitações para imitar e representar, assim como a linguagem verbal, ela também fez uso dos instrumentos musicais para suprir suas deficiências.

O problema de fato estava na verossimilhança, no que se considerava semelhança e ilusão. Parte daquilo que seria o reconhecimento de objetos semelhantes aos modelos da natureza tinha, na verdade, seu sentido completado pela imaginação do ouvinte, e não a semelhança real com o objeto em si. Apesar das possibilidades representativas, as associações poderiam ser apenas ilusórias, e não o reconhecimento de fato, o que trouxe indagações sobre a parcialidade do poder imitativo na música e se realmente a sua teoria era compreendida. A verossimilhança, para Morellet, mostrava-se incompleta, inexata e imparcial, e seu rigor não existia de fato, como se acreditava. Ao mesmo tempo, as fantasias do ouvinte com relação à música poderiam proporcionar mais possibilidades de associações, mais até do que o reconhecimento pela verossimilhança, que se mostrava imperfeito. Isso, do seu ponto de vista, era uma vantagem, pois colocavam-se os olhos no receptor da música, cuja subjetividade era orientada e restrita a um grupo de regras oriundas das teorias imitativas.

Ao falar e rever conceitos da teoria da verossimilhança, Morellet trouxe de volta esse elemento já presente em Charles Batteux, no tratado As belas artes reduzidas a um mesmo princípio, de 1746, e também refletiu sobre uma questão: para ele, a imitação era limitada porque os autores não sabiam exatamente o que era imitar. Se a música deixava margem para a fantasia, isso era prova da imperfeição da verossimilhança, pois as pessoas criavam em suas cabeças aquilo que ela não conseguia expressar. Como para ele a música era uma linguagem, e como a linguagem possuía imperfeições, isso 
também a tornava limitada, mas era de sua natureza ser limitada, e para Morellet os autores anteriores a ele não compreenderam que a natureza da música era ser incompleta. Mesmo porque a sociedade para a qual a música era feita não queria de fato ver a realidade e, assim, seu real modelo não era reconhecido na música.

Morellet (1777) expressou, através de alguns fragmentos de seu texto, como os seus conceitos dialogavam com os de outros autores anteriores a ele:

Eu considero como sinônimos, ao menos na questão presente, os termos exprimir e pintar (talvez ainda sejam); e como toda pintura é uma imitação, perguntar se a música possui uma expressão e em que esta expressão consiste é perguntar se a música imita e como.

Podemos distinguir dois tipos de objetos que a música procura pintar e exprimir: os objetos físicos, suas diversas ações, seus movimentos, seus efeitos e suas paixões ou, de modo geral, todas as afecções do coração humano. ${ }^{12}$ (p.366)

Ele considerou "imitar" e "pintar" termos sinônimos. A música, pela tradição, era considerada uma pintura das paixões humanas, como ele mesmo expressou no seu texto. Ao falar sobre a maneira como considerava a imitação na música, concordou com a ideia de Batteux $^{13}$ de que ela deveria ser julgada como se julga um quadro:

A música fala-me pelos sons: essa linguagem é natural para mim. Se não a entendo, a arte antes corrompeu a natureza do que

12 A tradução da obra Da expressão em música e da imitação nas artes, de André Morellet, foi realizada pela professora doutora Lia Tomás e gentilmente cedida para este livro.

13 Charles Batteux, As belas-artes reduzidas a um mesmo princípio, Parte III Onde o princípio da imitação é verificado por sua aplicação nas diferentes artes, Seção III - Sobre a música e a dança, Capítulo 2 - Toda música e toda dança devem ter uma significação, um sentido. 
a aperfeiçoou. Devemos julgar uma música como um quadro. Vejo neste último traços e cores cujo sentido eu compreendo; ele me deleita, ele me toca. O que se diria de um pintor que se contentasse em lançar sobre a tela traços audaciosos e massas das cores mais vivas, sem nenhuma semelhança com algum objeto conhecido? A aplicação se faz por si mesma à música. Não há disparidade; e se há uma, ela fortalece minha prova. O ouvido, dizem, é muito mais fino do que o olho. Logo, eu sou mais capaz de julgar uma música do que um quadro. (Batteux, 2009, p.139)

Morellet considerou a música uma linguagem também imperfeita, e na observância de suas imperfeições ele encontrou uma justificativa para explicar por que a imitação em música se fazia incompleta. $\mathrm{O}$ autor escreveu sobre a linguagem vocal e a musical e sobre a imitação:

Investiguemos os meios que ela possui para essas duas espécies de imitações, começando pela primeira.

A música sendo executada pelos mesmos órgãos da língua falada e afetando o mesmo sentido torna-se ela mesma uma língua. Portanto, pode ser útil investigar primeiramente se as línguas exprimem e imitam os objetos físicos, e por quais meios elas executam essa imitação.

A imitação dos objetos físicos pelo órgão da palavra parece ter guiado os homens na formação de todas as línguas. Quase todas as palavras que significam os objetos sensíveis e suas diversas ações pintam-nos, ao mesmo tempo, imitando o ruído que fazem, ou os movimentos que têm, ou as figuras que afetam, ou os efeitos que produzem etc.; tais são os nomes dados aos objetos que fazem ruídos ou que têm movimento, o trovão, o vento, os rios, os animais, as ações de picar, perfurar, escavar, voar, escorregar, quebrar etc. Os termos que exprimem estas ideias são imitativos em todas as línguas do mundo e esta imitação é reconhecida através de todas as alterações que as línguas sofreram no progresso das sociedades. (Morellet, 1771, p.367) 
Sua justificativa para considerar a música como linguagem vocal era que todas as sociedades usavam a sua língua na música, e utilizavam esta na significação dos objetos sensíveis, imitados de modelos retirados da natureza, e todos os objetos tinham a sua imitação reconhecida por aqueles que faziam uso da língua e da música.

No fragmento a seguir, o autor falou da forma de reconhecimento da imitação, na sua relação com a pintura:

Porém logo se abre uma fonte infinitamente mais abundante da qual a imitação poderá jorrar: é o conjunto, a combinação destes mesmos sons na frase e no discurso. Aqui essas primeiras analogias fracas, ao menos em aparência, entre as palavras e as coisas, encontrando-se reunidas, prestam-se mutuamente uma nova força. A imitação torna-se mais verdadeira, oferecendo-nos mais traços ao mesmo tempo. É certo que essa parte da frase, o murmúrio de um córrego que desliza sua correnteza prateada etc., forma uma imitação cuja verdade não pode ser desconhecida; a semelhança do quadro aumenta, em maior razão, que o número de traços; quando eu desenho um rosto, se um ou dois golpes do lápis, mesmo verdadeiros, são ainda equivocados, três ou quatro não o são. (Morellet, 1771, p.369)

A poesia, para Morellet, era o gênero que expressava todas as coisas e todos os pensamentos. Assim ele descreveu a sua função:

Como as línguas, como a poesia, ela escolherá, dentre os objetos sensíveis, os sons, as ações, os movimentos, os efeitos e em geral todas as circunstâncias que podem ser imitadas pelos sons, pelo movimento da voz e pelas diversas espécies de instrumentos; ela pintará os ruídos e os sons, pelos sons mais análogos; os movimentos pelos movimentos, a elevação de um objeto pelos sons elevados [agudos] e sua profundidade pelos sons graves; a distância pela oposição destes dois tipos de sons, a sequência pelos sons apoiados e o enfraquecimento por graus, como as impressões que ocorrem em nossos sentidos quando um objeto se distancia e desaparece; 
sua aproximação por uma marcha contrária; a violência de uma torrente que arrasta tudo em sua passagem, por uma sucessão rápida de sons fortemente pronunciados e ligados em conjunto, que representam o movimento dessa massa de água agindo como um corpo sólido. [...] (Morellet, 1771, p.371)

A poesia conduziu a tarefa de escolha dos objetos sensíveis a imitar. Ligada à linguagem verbal, somente ela era capaz de nomear todas as coisas. Assim, a poesia e logo em seguida a música poderiam ter sua função realizada. Sem a nomeação pela palavra, os objetos imitados da natureza não seriam usados nas artes e na música. Batteux também se referiu à língua como meio a que os sentimentos se ligavam para serem comunicados. A diferença, com relação a Morellet, estava no fato de que, para este, a música instrumental também poderia pintar os objetos da natureza. Já Dubos não concordava com esse poder da música instrumental. Considerava que ela só teria significados se ligada às palavras, servindo como mero apoio nos momentos em que a palavra não poderia atuar. Mesmo para Batteux a imitação na música instrumental poderia ser possível parcialmente, pois ela ficaria confusa sem o apoio da palavra, embora admitisse que era capaz de produzir sensações nos ouvintes, já que a música, em seu estado primeiro, deveria ter elementos dela própria para serem usados na composição da ópera.

Sobre a linguagem, e em concordância com Morellet, Batteux (2009) escreveu na Seção III do seu tratado:

A palavra nos instrui e nos convence, ela é o órgão da razão; mas o tom e o gesto são órgãos do coração: eles nos comovem, nos envolvem, nos persuadem. A palavra só exprime a paixão por meio das ideias às quais os sentimentos estão ligados e isso pela reflexão. O tom e o gesto chegam ao coração diretamente, e sem nenhum rodeio. Em resumo, a palavra é uma linguagem de instituição, que os homens fizeram para comunicarem mais distintamente suas ideias. [...] linguagem da qual todas as expressões são antes da própria humanidade do que dos homens! [...] Trata-se do retrato ingê- 
nuo de nossos pensamentos e de nossos sentimentos: tal é, ou deve ser, a conversação. [...] Escolhe-se com algum cuidado, porém, com discrição e modéstia, as palavras, os tons e os gestos mais próprios e mais agradáveis: trata-se do discurso e da narrativa segundo o estilo elevado. (p.135-6)

Embora Morellet e Batteux concordassem quanto aos significados das palavras e que nomeavam os objetos utilizados para imitação, Morellet considerava a imitação arbitrária, criada pela própria imaginação, e fazia surgir relações onde elas não existiam.

Não me estenderei nesta enumeração que é bem incompleta, mas que pode, entretanto, dar algumas ideias dos recursos que a música possui para imitar os objetos sensíveis.

Diríamos que esta pretensa imitação é absolutamente arbitrária e obra de uma imaginação que criou para si mesma, as ficções agradáveis que vê relações e semelhanças onde não existem. Qual semelhança pode haver entre o nascer do sol, o frescor da manhã e todos os meios da música?

Sem dúvida, a imitação que atribuímos aqui à música supõe semelhanças, ou bem mais, analogias (que são semelhanças mais fracas e mais distantes) entre os meios da imitação e o objeto imitado. Mas estas analogias não podem ser contestadas. O uso que fazemos delas prova a sua realidade. Sabemos bem que a música não pode ser fresca como o ar da manhã, nem suave como o odor que a terra umedecida pelo orvalho exala ao nascer do sol. Mas é necessário que haja qualquer coisa em comum entre as impressões que experimentamos com um belo nascer do sol e a sensação que recebemos de um certo emprego dos sons, para que tenhamos imaginado pintar, pela música, o nascer do sol e o frescor da manhã. (Morellet, 1771, p.373-4)

Com esse exemplo, o autor quis dizer que a imitação se fazia por analogias, e não por semelhanças. O termo "analogia" foi usado para sinalizar uma distância maior em relação ao objeto imitado, 
pois o termo "semelhança" promovia uma aproximação maior em relação a ele. Sensações como o "frescor da manhã" ou o "odor suave de terra umedecida" não poderiam ser imitadas pela música, mas o emprego de alguns sons poderia levar a imaginação a pintar essas sensações. Essas analogias, segundo o autor, consideravam semelhanças no processo de imitar, trazendo uma ideia falsa e irreal da teoria da verossimilhança nas teorias da imitação.

Morellet ainda estabeleceu relações entre os fenômenos e os efeitos da música, valendo-se do uso da metáfora. ${ }^{14}$ Disse que esse era um termo empregado para exprimir impressões próprias de um órgão dos sentidos em outros que não receberiam originariamente essa impressão. Para justificar essa ideia, ele apresentou exemplos, como os que aparecem no texto a seguir.

Esta analogia pode ser ainda provada pelas metáforas empregadas em todas as línguas para pintar os fenômenos e os efeitos da música.

O que é a metáfora? É o uso de uma expressão empregada para exprimir impressões feitas sobre um de nossos órgãos, para pintar impressões referentes a outro órgão. Quando dizemos uma voz fresca e brilhante, emprestamos essas expressões do sentido de tocar e de olhar, pois não há frescor, rigorosamente falando, que se possa tocar e brilhante que se possa ver. Entretanto, estas expressões são acolhidas em todas as línguas e não são equivocadas em nenhuma delas. De onde vem isso? Há uma analogia, uma semelhança, uma relação entre os três tipos de impressões recebidas pelo toque, de um corpo frio, pela vista, de um objeto brilhante, e pelo ouvido, da

14 A palavra "metáfora" quer dizer transferência de significado. Abbagnano (2007) traz: "'A metáfora consiste em dar a uma coisa um nome que pertence a outra coisa: transferência que pode realizar-se do gênero para a espécie, da espécie para o gênero, de uma espécie para outra ou com base numa analogia' (Poet., 21, 1457b 7). A noção de metáfora algumas vezes foi empregada para determinar a natureza da linguagem em geral. Como instrumento linguístico, hoje sua definição não é diferente da definição de Aristóteles" (Abbagnano, 2007, p.667). 
voz que nós chamamos de fresca e brilhante. O que faz essa analogia? Será que na parte mais sensível de nós mesmos, as fibras que recebem estes três tipos de impressões são vizinhas, comunicam-se reciprocamente suas vibrações, chegam a um centro comum etc.? Podemos esgotar-nos em conjecturas metafísicas sobre este sujeito delicado, sem encontrar nada de satisfatório; mas os fatos não podem ser negados; os fatos, ou seja, o emprego deste tipo de metáfora em todas as línguas e a realidade da analogia que este emprego supõe. (Morellet, 1771, p.374-5)

A música, para Morellet, funcionava então como uma metáfora. Os órgãos aptos a captar determinados sentidos recebiam impressões a serem captadas por outros. Essa correspondência entre os órgãos dos sentidos autorizava a música a pintar, através dos sons, aquilo que deveria causar impressões sobre outros sentidos. Então, como as línguas, ela se apoiava na analogia entre as impressões produzidas sobre órgãos diferentes. Mais um elemento para validar sua ideia de que a música era uma linguagem, como a linguagem verbal.

Ainda nesse percurso, o autor afirmou que a música encontrou um meio-termo para expressar objetos ligados a diferentes sentidos pela inflexão da voz.

O ruído e o movimento, por exemplo, um sensível aos olhos, o outro sensível ao ouvido, correspondem-se reciprocamente e existem em conjunto no objeto físico. A música aproveita desta ligação e se não pode descrever um objeto pelas inflexões da voz, ele o imita pelo movimento, ou ainda, ela reúne frequentemente estes dois movimentos de imitação e de expressão que se prestam um apoio mútuo.

O exemplo dessas analogias obscuras, que dirigiram os homens na formação da linguagem, faz, portanto, compreender como a música pode servir-se daquelas que nós indicamos; e por que na música, que é uma língua, os homens teriam feito mais difíceis? Não podemos dizer, precisamente, a razão da música é mais do que a língua falada, uma obra da arte, ela é bem mais uma língua de 
convenção e teve que se contentar mais facilmente a semelhanças menores? Mais fraca do que a natureza, ela teve que tomar todos os apoios que encontrou em sua rota. (Morellet, 1771, p.376-7)

Segundo o autor, um dos motivos para que a música usasse o artifício da arbitrariedade seria o fato de que a sua fraqueza era maior do que a da natureza, daí valer-se de todos os recursos que encontrou no seu caminho para se constituir, embora os homens fizessem associações objetivas, de acordo com as semelhanças previstas nas teorias imitativas.

As ideias e as impressões, segundo Morellet, despertavam e serviam adequadamente à música. Ela apenas fazia que qualquer ruído tomado de um objeto físico da natureza ou de alguma circunstância fosse compreendido. Desse modo, orientou a imaginação a ter a sensação do que considerava ter sido imitado, mas que em realidade consistia apenas em um forte elo entre ideias e palavras. $\mathrm{O}$ autor escreveu:

Se me permitem expor ainda uma explicação mais metafísica deste fenômeno, eu diria que é a facilidade com que as ideias e as expressões se ligam, tanto entre elas quanto às circunstâncias mais leves. Um exemplo notável é aquele que nos oferece a ligação das ideias com as palavras, mesmo que as palavras não tenham, com os objetos das ideias, nenhuma das relações sobre as quais dissemos acima que as línguas estabelecem um tipo de imitação. Vemos fortes elos de impressões e de ideias vinculadas por um fio imperceptível a um pequeno número de sílabas e se reproduzindo rapidamente quando estas sílabas são pronunciadas. Basta ter compreendido uma palavra ao mesmo tempo que adquirimos uma ideia, no qual experimentamos uma impressão, para que se estabeleça entre a palavra e a nossa ideia, ou a impressão, uma ligação que jamais será rompida. A palavra feia sempre revelará em mim a ideia de uma coisa desagradável, porque foi pronunciada diante de mim, as sílabas que a formam, mostrando-me um objeto desagradável. (Morellet, 1771, p.378) 
Ele ainda fez considerações sobre as paixões humanas, sobre como elas foram expressas a partir da declamação natural do homem, distintas nas diferentes artes, mas que a partir delas se estruturaram. O próximo fragmento aborda esse tema:

Passemos agora à expressão das paixões e das afecções diversas do coração humano e vejamos quais são os meios que a música possui para imitá-los.

Todas as paixões e todos os sentimentos do coração humano possuem sua declamação natural; eu entendo por declamação natural: $1^{\circ}$ ) os acentos das grandes paixões quando elas se produzem externamente pelas vozes inarticuladas, como os gritos, os suspiros, os soluços ou que se exprimem por palavras que não formam em nada os discursos sequenciais, tais quais as interjeições; 2을 inflexões da voz que recebem o discurso sequencial empregado para exprimir as mesmas paixões e outros sentimentos do coração humano.

Eu chamo esta declamação natural para distingui-la da declamação oratória e teatral, que é a mesma fundada sobre os acentos das grandes paixões, e sobre as quais o uso da língua falada liga as palavras e as frases do discurso sequencial. Pois eu digo que esta declamação natural é o modelo que a imitação musical copia.

O órgão da palavra, sendo um dos mais potentes meios que a natureza forneceu ao homem para exprimir e pintar suas ideias e seus sentimentos, é bem natural que a música sirva-se dela e que lhe empreste sua expressão. Ela escolherá, portanto, na declamação natural os acentos mais marcados; ela lhes colocará mais arte preparando-os para aumentar seu efeito; os tornará mais sensíveis opondo contrastes (um dos meios mais potentes das artes); os reconduzirá mais constantemente, pronunciando-os mais fortemente, o que nos ocupará por mais tempo; em uma palavra, ela produzirá, por seu meio, essas impressões fortes e profundas que todas as almas sensíveis provaram, e que somente esses poderão reconhecer, os que não são dignos de senti-los. (Morellet, 1771, p.380) 
A música, para Morellet, imitava os acentos das paixões da declamação natural, e sobre elas triunfou. Os gritos naturais das paixões encontrados na natureza seriam intensificados pelo compositor, mas através de uma voz estendida e apoiada. Na representação no palco, o ator os intensificaria ainda mais, para além do que o compositor escreveu. Batteux também fez alusão aos sentimentos e às paixões humanas. Com relação à declamação natural mencionada por Morellet, declarou que o significado primeiro do tom de voz deveria ser conservado, porém intensificado pela música, pela arte.

Essa intensificação encontrou correspondência entre os dois autores. Para Batteux (2009):

[...] o objeto principal da música e da dança deve ser a imitação dos sentimentos ou das paixões, ao passo que o da poesia é principalmente a imitação das ações. Entretanto, como as paixões e as ações estão quase sempre unidas na natureza, e devem também encontrar-se juntas nas artes, haverá essa diferença para a poesia, e para a música e a dança: na primeira, as paixões serão empregadas como meios ou motivos que preparam a ação e a produzem; na música e na dança, a ação será somente uma espécie de tela destinada a carregar, sustentar, conduzir e ligar as diferentes paixões que o artista quer exprimir.

[...] que, se o tom da voz e os gestos tinham uma significação antes de se fazer algo, eles devem conservá-la, eles devem conservá-la na música e na dança, assim como as palavras conservam a sua na versificação; por consequência, toda música e toda dança devem ter um sentido.

[...] que tudo o que a arte acrescenta aos tons da voz e aos gestos deve contribuir para aumentar esse sentido e para tornar sua expressão mais enérgica. (p.136)

No que concerne à música instrumental, Morellet considerava que ela possuía aptidão para imitar, tinha uma voz e um acento próprios, e que a combinação de instrumentos musicais poderia expressar sentimentos e paixões. Embora tenha afirmado que, so- 
zinha, a música instrumental era uma linguagem sem vogais, estas seriam dadas quando tocadas em conjunto com a música vocal. $\mathrm{O}$ autor escreveu:

Não é necessário restringirmos apenas ao órgão da voz a faculdade de imitar os acentos das paixões; os instrumentos também possuem esta aptidão e alguns em alto grau, sobretudo nas mãos de artistas sensíveis. Pela mesma razão, um grande número de instrumentos que possuem sua voz e um acento que lhe são próprios, empregados alternadamente, combinados em conjunto e se prestando um apoio mútuo, poderão exprimir os sentimentos e as paixões de uma maneira muito verdadeira para fazer-nos reconhecer e, ao mesmo tempo, muito delicada para deixar-nos o mérito e o prazer de adivinhá-los. A música instrumental sozinha será, ao menos, uma língua que se escreve sem vogais, como qualquer língua oriental; e se ela acompanha as palavras cantadas, as vogais são colocadas. (Morellet, 1771, p.382)

Ainda com relação à declamação natural, Morellet questionou sua expressão através da música. Sendo essa declamação arbitrária, ela poderia exprimir, pela entonação, um sentimento consagrado a um país, mas díspar ou contrário a ele se comparado com outra nação. Assim ele se expressou sobre essa diferença:

Quando a diferença da declamação de uma mesma paixão entre nações diferentes for maior do que a que se encontra em vigor em cada uma, a música, copiando a declamação nacional, terá uma expressão bem verdadeira porque ela despertará todas as ideias e todos os sentimentos que exprimem e que despertam, em cada país, as palavras e os discursos acentuados, aos quais estão vinculados tais sentimentos e ideias. (Morellet, 1771, p.384)

Mas era a analogia, segundo a sua visão, que encerrava a verdade das relações e suas combinações. Através dela fundamentavam-se as paixões humanas e os sentimentos do coração. Os movimentos 
das paixões também eram arbitrários, e eram eles que a música pintava. Dessa maneira, Morellet elaborou uma espécie de lista de analogias usadas pela música como imitação, mas, como ocorria com a metáfora, o verdadeiro destino de alguns efeitos se dirigiria aos ouvidos, numa associação falsa e imaginada pelo ouvinte:

As analogias que destacamos acima, entre os objetos físicos e os meios que a música emprega, podem ajudar-nos a conceber esses que tratamos aqui.

É bem difícil explicar com precisão em que eles consistem; mas é suficiente que sejam reais e que nós os reconheçamos nos efeitos que a música produz. Eu indicaria aqui alguns, que autorizariam supor muitos outros que não nos encontramos em condições de indicar.

Há uma relação entre os sons abafados e o fechamento do coração, cujos desgostos da alma ou o sentimento do medo nos fazem experimentar.

Há uma relação entre certos movimentos na música e a agitação interior que as paixões causam; entre os movimentos lentos e o abatimento.

Há uma relação entre um movimento moderado mas andante, e a serenidade do espírito; entre um movimento vivo e a alegria; e pela razão contrária, entre a lentidão do canto e a tristeza.

Há uma relação entre a marcha de um canto que surge cromaticamente e o sentimento da dor, mesmo que ela seja muda.

Há uma relação entre o modo menor e a melancolia, e entre o modo maior e a alegria.

Há uma relação entre certos intervalos, tais como a terça menor, a sexta menor aumentada, a quarta e a falsa quinta descendente, etc., e os sentimentos doces; e entre os intervalos de terça maior, de quinta, de sexta maior ascendente e os sentimentos mais firmes e decididos.

Estando reunidos os sons que formam estes mesmos intervalos, formam harmonias que possuem relações, analogias da mesma espécie ou, ao menos, caracteres muito diferentes segundo a natureza dos intervalos etc. (Morellet, 1771, p.387) 
Morellet considerava que essa sequência de arbitrariedades possuía um fundo de verdade. A sua maior ou menor confirmação dependeria de o artista realçar uma ou outra característica. Mas o que se depreendia dessas observações era a imitação, que se mostrava incompleta. Havia uma parte de verdade nela, e o restante era completado pela imaginação do ouvinte, embora ele também tivesse concordado que a música poderia imitar e pintar objetos físicos, ações diversas, as paixões e alguns sentimentos da alma.

A verdade de tudo isso poderia ser checada se a observação fosse feita em separado, mas havia alguma verdade nas analogias, embora tudo fosse muito relativo.

Em consequência, a música fazia sua imitação de maneira imperfeita, ao tentar pintar os objetos físicos ou seus efeitos, os acentos da linguagem falada ou os gritos da paixão. A imitação era vaga, e o quadro composto não podia ser semelhante. $\mathrm{O}$ autor afirmou que o canto de uma voz ou o som de um instrumento em nada se assemelhava ao canto de um pássaro, a uma tempestade ou a uma batalha. Todos os acentos não eram realizados fielmente pela música, e sim por associações. As afecções do coração humano eram díspares em relação ao produto da música que disse tê-las imitado. "Com tantas diferenças do original ao pretenso quadro, o que torna a imitação a expressão da música?” (Morellet, 1771, p.390).

Com essas explicações, o autor tinha em mente que era da natureza da música não realizar nem completar a imitação com exatidão:

Essa dificuldade é fundada sobre uma falsa ideia que fazemos sobre o que deve ser a imitação nas artes: é necessária maior exatidão.

É mais fácil concordar que a música exprime e imita os objetos físicos e as paixões do coração humano, se nos convencêssemos de que sua imitação não tem necessidade de ser nem completa, nem exata, nem rigorosa; que ela deve ser imperfeita e, diferente da natureza em algum modo, sob a pena de perder uma parte de seus direitos sobre a nossa alma e poder produzir em nós as impressões que ela quer obter. (Morellet, 1771, p.391) 
O fundamento da imitação era embelezar a natureza, oferecer à alma um prazer maior do que a sua verdade. A semelhança embelezada era ofertada pelas artes, e a imitação se comprometia em se fazer e se tornar melhor do que a natureza pela execução das artes. Estas, ao escolherem um objeto, atribuíam-lhe belezas que originariamente não possuía, mas também não poderiam falar do que não conheciam. Entretanto, através do objeto, um fundo de verdade era encontrado no reconhecimento, mesmo que a arte tivesse se afastado da verdade rigorosa, da precisão, sacrificando esses elementos em prol de imagens harmônicas aperfeiçoadas com vistas a provocar maior prazer.

A arte consistia, segundo ele, em dar aos homens algo melhor do que daria a própria natureza:

A música toma licenças semelhantes; ela pode cadenciar sua marcha, arredondar seus períodos, apoiar, fortificar a voz pelo acompanhamento que certamente não existe na natureza. Isso, sem dúvida, altera a verdade da imitação, mas aumenta, ao mesmo tempo, a sua beleza e oferece à cópia um charme que a natureza recusou ao original. (Morellet, 1771, p.393)

As artes promoviam, segundo o autor, algo a mais do que a imitação precisa da natureza. Elas poderiam alterá-la, adorná-la, com o objetivo de agradar. Poderiam unir traços que nunca existiram juntos na natureza e assim oferecer prazeres que a verdade jamais poderia dispor. Então, a semelhança com a verdade não existia de fato. Para aperfeiçoá-la, ela deveria existir na natureza, mas não existia, embora se considerasse que isso acontecia.

Morellet ainda declarou que essa incompletude não era destituída de prazer e que se mostrava como uma vantagem:

Mas o maior prazer que a imitação menos rigorosa da verdade produz é a reflexão sobre o artifício engenhoso que ela utiliza para nos seduzir; prazer confuso mas vivo, sem o qual o maior encanto 
da imitação é destruído, e que desaparece desde que a imitação é tomada pela própria verdade e a ilusão é inteira e completa. (Morellet, 1771, p.395)

Se as artes usassem aquilo que apenas convinha aos sentidos que deveriam empregar e não tomassem um pelo outro, não seriam capazes de proporcionar prazer. Se a imitação fosse perfeita, não haveria o reconhecimento de seus modelos e objetos, e isso, segundo o autor, não seria mais ilusão, mas sim tomar o real pelo falso. Era pelo fato de a imitação ser incompleta que ocorria o reconhecimento, e então a ilusão deveria ir até certo ponto. Num primeiro momento, a arte deveria enganar, fazer crer que se via a natureza, mas, na sequência, segundo Morellet, era preciso perceber que a arte tinha estado ali. Era a ilusão seguida de sua real descoberta que proporcionava os maiores prazeres perante a obra de arte.

Sobre a interrupção da ilusão, ele escreveu:

E não é necessário crer que a ilusão, assim interrompida, seja menos forte e menos viva do que no momento em que ela ocorre. Ao contrário, estou persuadido de que nesse combate da verdade contra ela, ela ganha novas forças para subjugar nossos sentidos e nossa imaginação. Quando ela retorna vitoriosa, somos inteligentes e nos colocamos à frente de seu jugo. Prestamo-nos a todas as suposições, nos afastamos de tudo o que possa nos confundir e desmentir os erros que nos são caros; e quão fácil é para a arte nos enganar quando nos tornarmos seus cúmplices? Nossa sensibilidade excitada, nossa imaginação exaltada pelas belezas, as riquezas e esta espécie de luxo das artes nos dispõem a uma ilusão que, mesmo com pouca duração, atua sobre nós com impressões mais fortes do que uma imitação mais exata com a qual a ilusão se sustentaria por mais tempo. (Morellet, 1771, p.399)

O prazer não estava, na realidade, no que era ouvido ou visto, mas sim no que era compreendido, no que nosso conhecimento entendia por imitação. 
Eu disse que esse princípio (que a imitação não deve ser inteira e perfeita) é comum a todas as belas artes e que podemos nos servir utilmente para resolver várias questões, desde muito tempo em voga, sobre a arte dramática, a poesia, a eloquência etc. (Morellet, 1771, p.400)

Sobre a imitação, o autor ainda escreveu:

No fundo, qual a necessidade de a imitação ser tão exata se a própria arte torna-nos mais indulgentes sobre a verossimilhança, e se esta imitação mais livre, tão imperfeita como a supomos, torna-se ela mesma verossímil? Pois é o que ocorre de fato: esses acessórios que olhamos como se nos afastando da natureza, a harmonia e a beleza dos versos, a nobreza (não digo a ênfase) da declamação criam sobre nós impressões vivas, nos dispõem fortemente à ilusão para tornar inútil uma imitação mais minuciosa, ao mesmo tempo que nos oferecem prazeres que a imitação exata jamais nos oferecerá. (Morellet, 1771, p.402)

Nesse texto, diferentemente de Batteux, Morellet afirmou que a imitação na verdade ocorria de maneira mais livre, que no fundo o observador perante a obra de arte era muito mais indulgente com a verossimilhança, embora no campo teórico se exigisse a imitação exata e rigorosa. A imperfeição era tal que ela mesma se tornava verossímil. Todos os acessórios que na verdade nos distanciavam da natureza eram eles mesmos tão reais que provocavam uma forte ilusão, tornando inútil a imitação mais minuciosa, pois esta, por si só, não permitiria perceber a ocorrência da ilusão e era por isso que poderia produzir prazer diante da obra de arte.

No seu texto, Morellet procurou demonstrar que a questão da verossimilhança na música era falsa e arbitrária, que aquilo que era considerado "imitar" em música também era uma ilusão, ao se acreditar que o seu conceito se fundamentava na forma como era pensado. O que era considerado semelhança em música não era encontrado de fato na natureza, embora as associações induzissem 
o ouvinte a pensar que isso acontecesse. A voz ou o instrumento musical poderiam comunicar as paixões, mas elas não se mostravam desse modo na natureza. Os pássaros, os trovões e outros efeitos da natureza não eram semelhantes aos timbres vocais e instrumentais utilizados no que se dizia ser sua imitação, tampouco traços inexistentes na natureza ocorriam de fato na música.

Morellet era partidário da imitação leve, que as alusões a fenômenos da natureza pudessem servir de referência, mas achava que não constituiria uma falha se não fosse feita a real transposição dos fenômenos naturais para a música. As representações seriam semelhantes de qualquer maneira, ao serem feitas alusões aos modelos imitados da natureza, mas elas poderiam reunir apenas vários traços, sem a necessidade de correspondência exata entre todos eles, já que, de toda forma, a verossimilhança não existia de fato. Era nisso que estava o prazer da música. Para o autor, a arte nada ganharia se ele fosse ao teatro para ver a realidade, a não ser que buscasse a imitação, a ilusão. Esta só existia porque não havia a representação da realidade de fato.

Nessa questão, ele pensava de maneira diferente dos autores mencionados anteriormente. Concordou em muitos aspectos com a imitação, mas, quanto à verossimilhança, discordou em relação a Batteux e Dubos.

A música não poderia imitar plenamente. Ela era falha com relação à teoria da verossimilhança e tudo o que fazia em nada se assemelhava à natureza. Mas era por isso mesmo que provocava prazer, por ser incompleta e não respeitar essa regra requerida para as artes.

$\mathrm{O}$ autor assim terminou o seu texto:

Como puderam crer que a arte ganharia alguma coisa se confundindo assim com a natureza e a copiá-la servilmente? Seria aniquilá-la querendo aperfeiçoá-la. Se não quero ver o que se passa na rua e em uma casa, não tenho necessidade de ir ao teatro. Dizem-me que este espetáculo é tão semelhante que é a própria coisa; mas é exatamente nisso que ele é vicioso, pois não é a própria coisa que eu quero ver, é a sua imitação. 
Retornemos à música, de cuja digressão não nos afastamos muito, e concluamos que, como as outra belas artes, ela pode se contentar com uma imitação leve, que isso não será visto como fraqueza, mas delicadeza de expressão; que as fracas analogias serão por si mesmas meios de imitação; que sua imitação não será menos verdadeira e que suas representações serão semelhantes, senão pela exatidão de cada traço, mas ao menos pelo número de similitudes que ela será capaz de reunir; e enfim, que a imitação e a expressão talvez lhe pertençam em um grau muito mais alto do que nas outras artes, que possuem sobre nós um grande império, e que jogam nossos sentidos e nossa imaginação em tão doces ilusões. (Morellet, 1771, p.404) 


\section{Considerações finaIS}

Ao longo deste livro, observamos o percurso que o conceito de imitação, na ópera francesa do século XVIII, seguiu em sua trajetória. Surgido antes na literatura, pela estrutura do próprio texto da tragédia antiga e da tragédia clássica francesa do século XVII, esse conceito delineou a representação teatral trágica com regras definidas quanto à imitação baseadas em modelos retirados da natureza.

A partir da arte teatral, com todas as suas regras e normas, orientada pelo aspecto imitativo como tradição para o teatro trágico, a ópera apropriou-se desses elementos e constituiu-se como uma tragédia em música ou tragédia lírica, incorporando as teorias imitativas e da verossimilhança e, em sua ação, as histórias, as narrativas e os mitos como representação, todas da arte teatral, para se constituir como um espetáculo autônomo.

Quando a ópera era avaliada segundo as regras, a avaliação era a mesma do texto literário e da representação teatral. Muitas vezes, a música era avaliada como sendo um deles, era tomada como se fosse eles mesmos. E isso acontecia porque a prerrogativa da imitação era reproduzir, em objetos não naturais, cópias a partir de modelos retirados da natureza, através da verossimilhança, produzindo assim a ilusão de o próprio modelo estar ali, mas aperfeiçoado e controlado pelo engenho da arte. A natureza era o modelo a ser imitado, ela era 
sinônimo de razão, e a imitação deveria realçar os aspectos racionais para satisfazer essa condição $\mathrm{O}$ modo como a razão era demonstrada na ópera era através do texto literário, pela linguagem verbal.

A linguagem verbal continha os elementos racionais desejados para satisfazer essa condição, os quais davam significados à música. Esta deveria exaltar os aspectos vocais, e por isso os recitativos da ópera francesa, associados à declamação das tragédias dos antigos, recebiam as maiores cenas dramáticas. Uma ópera francesa, como observado nas discussões entre Raguenet e Lecerf, no início do século XVIII, sem o aspecto musical era uma peça de teatro como qualquer outra. A música deveria realçar esses aspectos verbais, e para isso precisava ser inteligível. Por isso, quando a língua francesa foi criticada no canto por Raguenet, dando margem à sua incompreensão, na verdade apontavam-se falhas na imitação e o fato de que a razão não era realmente satisfeita através desse domínio. Daí esse autor ter preferido o aspecto agradável da música italiana, dentre tantos outros elementos, usando como critério não a verificação da execução das regras, mas o seu próprio gosto pessoal. Para ele, os aspectos da musicalidade italiana, mesmo burlando as regras dramáticas, eram agradáveis às suas sensações, e estas sensações bastavam por si mesmas.

O elemento imitativo permaneceu desde finais do século XVII e ao longo do século XVIII, como verificamos nos textos analisados neste livro. A teoria imitativa manteve-se como concepção para as artes até o fim da monarquia, apesar de suas transformações. $\mathrm{O}$ que mudou, de acordo com os textos, foi a concepção de natureza. Paralelamente à concepção de natureza, que modificou o dispositivo imitativo, os textos mostraram em que medida a sociedade, em transformação, manteve-se ou distanciou-se das regras das teorias imitativas. Observou-se que gradativamente essas teorias foram modificadas e enfraquecidas, absorvendo outros elementos, como a ideia da música como linguagem dos sentimentos e posteriormente como sinônimo de expressão.

Num segundo momento, a concepção de natureza passou da razão para o sentimento, aspecto confirmado pelos teóricos Dubos, 
como expresso em seu tratado Reflexões críticas sobre a poesia e a pintura, e Batteux, na sua obra As belas-artes reduzidas a um mesmo princípio. A imitação deveria realçar a verdade dramática da realidade, por isso os sentimentos eram os modelos retirados da natureza para a imitação. Embora a música ainda não possuísse significados em sua concepção racional, aceitava-se que ela poderia provocar sensações e até mesmo mover as paixões humanas, que eram movidas de maneira controlada na concepção racional.

Outro elemento que suscitava questionamentos era o da música instrumental, já que a música vocal era a única que possuía significados e satisfazia à razão, por conter a linguagem verbal, à qual a música era subalterna. Dubos aceitava a música instrumental desde que esta servisse para realçar os aspectos em que a linguagem verbal não conseguisse comunicar os sentimentos do texto. Já para Batteux essa música poderia comunicar as paixões humanas, mas sem a palavra, sem o texto, os sentimentos ficariam confusos e não seriam controlados.

O conceito de imitação, para Dubos e Batteux, ou sua estética clássica,

[...] estão fundamentados no conceito de natureza, proveniente da filosofia de Descartes. Aqui, pensamos que a natureza, tal como ela é, não é bela nem perfeita. Portanto, devemos buscar, trabalhar, imobilizar a natureza para extrair dela a realidade, a verdade e a essência. Isso também acontece com relação às paixões. As paixões que geralmente se sentem não são imagens das paixões verdadeiras. Estas são representadas nas tragédias de Corneille e Racine. É fácil verificar: quando Batteux afirma que "o objeto principal da música e da dança deve ser a imitação dos sentimentos ou das paixões", estes "sentimentos ou paixões" não são os únicos que devem ser, mas tais como são idealizados. (Naito, 2002, p.10, tradução nossa)

Os textos dos outros autores analisados, como Le Brun, Saint-Mard, Grandval, Bollioud-Mermet e Blainville, apresentaram uma descrição do dia a dia das representações de ópera. Relataram 
aquilo que a audiência esperava no que se referia à imitação e ao cumprimento das regras, concordando, em maior ou menor grau, com Dubos e Batteux. Mencionaram aspectos do tipo de público que assistia as representação de ópera, assim como o que era considerado correto ou incorreto, conforme o gosto, em relação ao texto, à representação teatral e mesmo à música. Esses textos demonstraram o quanto a tradição era lembrada ou esquecida, em que grau as teorias imitativas satisfaziam ao gosto vigente. Verificou-se um estranhamento entre a música e a representação dramática. Se, muitas vezes, a representação teatral da ópera satisfazia ao esperado, quanto ao gosto, cumprido pelas regras, a música deixava a desejar nesse aspecto. Havia então uma espécie de conflito e não conciliação entre os aspectos verbais e musicais, e o que se tentava, segundo os textos, era fazer a música modelar-se conforme a tragédia teatral. Ao mesmo tempo que essa disparidade era constatada, via-se que a música tinha o poder de agradar, e agradava mais ainda às classes não aristocráticas, que não conheciam e não se fiavam nas regras imitativas na ópera.

A natureza como sinônimo de sentimento trouxe, posteriormente, em meio ao movimento das Querelas dos Bufões, um olhar interno, e não mais externo, como era a natureza, e a música começou a ser considerada a linguagem dos sentimentos. Os embates, as disputas e tomadas de posição com relação à ópera bufa italiana e à opera seria francesa contavam com a participação de uma classe social que, desconhecedora das regras de bom gosto da classe aristocrática, ou tendo pouco conhecimento delas, não fazia questão de observar se as regras haviam sido cumpridas e se deixava levar pelo agrado dos sentimentos, pelas sensações promovidas pela música em si mesma, e não pelo respaldo literário nela contido. $\mathrm{O}$ que importava era o deleite dos sentidos, sem a preocupação com sua linearidade literária e o aperfeiçoamento dos costumes.

Enquanto as classes burguesas desejavam um divertimento dos sentidos na representação da ópera, sem esperar que isso atingisse o espírito, e muitas vezes frequentavam a ópera em função do status que isso significava, a aristocracia esperava que as regras fossem 
cumpridas, e nisso estava o sabor e o deleite do bom gosto para essa classe, na verificação de que todos os elementos esperados da representação satisfizessem seus anseios, e não só isso: esse equilíbrio na satisfação da razão e do bom gosto devia servir para o aperfeiçoamento dos costumes vigentes.

Essa postura da aristocracia frente à representação da opera seria e a favor dela no movimento das querelas foi combatida, por ter sido considerada por muitos enciclopedistas e filósofos como uma perpetuação do seu poder e dos seus costumes, e não dos costumes da França. A opera seria era, então, na visão dos iluministas, um instrumento de manutenção de poder, por isso deveria ser extirpada da sociedade.

A perpetuação das teorias imitativas, para a música e as artes, não só mantinha a tradição da cultura clássica, expressa nas obras de arte e nas artes teatrais, envolvendo a ópera. Ela simbolizava, na concepção dos filósofos iluministas, a manutenção da aristocracia no mesmo lugar do seu poderio.

Rousseau tomou posição contra a opera seria e combateu seu maior expoente na época, o compositor Rameau. Considerado representante da aristocracia e do racionalismo cartesiano, ele compunha óperas para agradar ao gosto da corte, seguindo as regras das teorias imitativas, embora mesmo na corte nem todos se satisfizessem com a sua música. Rousseau, além de combatê-lo como símbolo da aristocracia, procurou demonstrar que a música era a linguagem dos sentimentos, que os sentimentos eram o aspecto universal, e que a imitação deveria realçar esse aspecto universal do coração, como debatido na sua Carta à música francesa. Rameau, seguindo o pensamento racionalista, tinha na natureza o aspecto universal, pois ela refletiria as leis universais da natureza, comum para todos, e se concretizaria na tradição, na manutenção da satisfação da razão, embora a natureza fosse, naquele momento, sinônimo de sentimento, movendo através da música as paixões humanas, mas de maneira controlada.

Enquanto para Batteux a música era uma imitação, de forma idealizada, dos sentimentos ou das paixões, extraídos da natureza, 
para Rousseau a imitação dos sentimentos eram as paixões brutas e reais, da maneira como realmente os homens as sentiam. O conceito de imitação, portanto, não era o mesmo para os dois autores.

As querelas revelaram um quadro social em que a aristocracia estava em decadência. Nas artes, essa classe social esperava o cumprimento das regras, mas, na convivência com a classe burguesa, conheceu outro gosto, ao qual não importava e o qual não buscava o cumprimento das mesmas regras, para o qual os aspectos internos eram os juízes no julgamento da música. Esta só era aceita pelo grau de satisfação agradável que provocava, e não pela satisfação da razão ou pelo aperfeiçoamento dos costumes. Era a satisfação do coração, em conflito com a satisfação da razão, ao mesmo tempo que as teorias imitativas foram se transformando e deixando de ser critério para a produção das artes.

Mesmo depois das Querelas dos Bufões, prevaleciam as discussões sobre os significados da música, o que ela era sem o respaldo do texto literário. Nesse sentido, a música sempre apresentava problemas. Apesar de a ópera parecer não ser condizente com ela, música e texto pareciam objetos inconciliáveis.

No início da década de 1770, André Morellet tinha uma visão da música como expressão. Embora ainda fosse partidário das teorias imitativas, pensava que a música era diferente das outras artes no sentido imitativo e procurou responder às indagações sobre os significados dela e se deveria mesmo imitar, o que deveria imitar, como deveria imitar. Primeiro focou no que as pessoas compreendiam por imitação e afirmou que, na verdade, os autores não sabiam o que era imitar. Como a ópera não satisfazia totalmente o cumprimento das regras das teorias imitativas, afirmou que essa incompletude, esse não cumprimento das regras, era da própria natureza da música. Dada essa incompletude da música com relação ao imitar, Morellet retomou questões do tratado As belas artes reduzidas a um mesmo princípio, de Batteux, como o princípio da verossimilhança, afirmando que a música deixou margem para que o receptor criasse em sua cabeça associações subjetivas e ilusórias quanto à representação. Essas associações eram feitas através de 
analogias, e o que se produzia em música não era semelhante aos objetos imitados da natureza, pois ela não tinha, por exemplo, um rouxinol cantando com um som de violino ou um canto humano, como se pretendia na música.

As semelhanças que configuravam a ilusão através da verossimilhança eram arbitrárias. Na verdade, eram associações que induziam a fantasia do ouvinte, o qual acreditava que era imitação aquilo que de fato sequer existia na natureza e, portanto, nem poderia ser um modelo. Morellet via a música como uma linguagem, porque ela fazia uso do mesmo órgão produtor das palavras. A linguagem verbal possuía limitações para expressar todos os modelos e objetos da natureza e usava de associações para expressar o que desejava, o que também acontecia com a música, que se valia de associações, mas, nas teorias imitativas, isso foi tomado como reprodução dos modelos em si e considerava-se que a verossimilhança ocorria realmente, quando isso não era possível.

Os objetos imitados eram potencializados pela música vocal, por isso a poesia, símbolo da razão, ocupava lugar privilegiado em todas as línguas, pois fora usada para a representação de modelos da natureza por muito tempo. Assim, a música poderia escolher os objetos que gostaria de imitar e, tanto por meio da voz como dos instrumentos musicais, poderia sugerir representações sonoras através de analogias, mas que não eram de fato semelhantes aos objetos imitados.

Dessa forma, as relações entre língua e música possuíam um limite, apresentavam insuficiências e imprecisões, pois trabalhavam apenas com aproximações, e foram esses limites que nunca permitiram que a música efetuasse a imitação de modo eficaz. A verdade da qual ela pretendia se ocupar não existia de fato. A música poderia imitar, mas o problema estava na verossimilhança, na produção de ilusão, no reconhecimento de objetos semelhantes aos modelos da natureza. A teoria da verossimilhança utilizada para as outras artes não poderia ser a mesma para a música. Seria, na verdade, falsa para essa arte, pela sua incompletude, imparcialidade e inexatidão, sem o rigor cobrado das outras artes. 
A música deveria ser apreciada tendo-se consciência de que ela era incapaz de concretizar as regras das teorias imitativas, e nisso estava seu deleite: permitir que o ouvinte completasse, com a sua imaginação, aquilo que a verossimilhança era incapaz de realizar.

Os autores anteriores a Morellet, segundo este, não sabiam o que de fato era imitar. Eles tentaram fazer a música de ópera modelar-se, assumindo uma forma que não era a dela. Julgavam a música pelo viés literário, acreditando que o faziam. Justificavam sua associação com a linguagem verbal para o alcance de significados precisos. Era cobrado da música o comportamento de uma representação teatral, ou a complexidade da pintura de um quadro. Enquanto existiu a aristocracia, existiram as teorias imitativas, e estas, mesmos transformadas, se valeram, para a produção das artes, do conceito de imitação da ópera francesa, como visto neste panorama, que estendeu-se do início do século XVIII até um pouco além da sua metade. 


\section{REFERÊNCIAS BIBLIOGRÁFICAS}

ABBAGNANO, N. Dicionário de Filosofia. São Paulo: Martins Fontes, 2007.

ALMEIDA MARQUES, J. O. de. Apresentação. In: ROUSSEAU, J.-J. Carta sobre a música francesa. Campinas: IFCH-Unicamp, 2005.

ARISTÓTELES. Poética. Trad. Ana Maria Valente. Lisboa: Imprensa Nacional/Casa da Moeda, 2011.

Poética. Trad. Eudoro de Sousa. Lisboa: Imprensa Nacional/ Casa da Moeda, 1986.

BEAUSSANT, P. A música barroca da França "clássica". In: MASSIN, J.; MASSIN, B. História da música ocidental. Rio de Janeiro: Nova Fronteira, 1997.

BATTEUX, C. As belas artes reduzidas a um mesmo princípio. São Paulo: Humanitas/Imprensa Oficial, 2009.

BLAINVILLE, C. H. de. L'Esprit de l'art musical. In: L'Esprit de l'art musical, ou réflexions sur la musique, et ses différentes parties. Genebra: 1754. Disponível em: < http://www.chmtl.indiana.edu/tfm/18th/ BLAESP_TEXT.html>. Acesso em: 26 mar. 2013.

BOLLIOUD-MERMET, L. De la corruption du goust dans la musique françoise. In: Music and Theatre in France in the $17^{\text {th }}$ and $18^{\text {th }}$ Centuries. An AMS Reprint Series. Lyon: Delaroche, 1746. Disponível em:

$<$ http://www.chmtl.indiana.edu/tfm/18th/BOLCOR_TEXT.html $>$. Acesso em: 26 mar. 2013.

BORBA, F. S. (Org.). Dicionário Unesp do Português Contemporâneo. Curitiba: Piá, 2012. 
BORNHEIM, G. A. Introdução à leitura de Winckelmann. In: WINCKELMANN, J. J. Reflexões sobre a arte antiga. Porto Alegre: Movimento, 1975.

BURY, E. et al. Littérature française du XVII e siècle. Paris: Presses Universitaires de France, 1992.

CASSIRER, E. A filosofia do Iluminismo. Campinas: Editora da Unicamp, 1994.

D’ALEMBERT, J.-Le R. De la liberté de la musique. In: Mélanges de littérature, d'histoire, et de philosophie, nouvelle édition, t.4. Amsterdã: Zacharie Chatelain, 1759. Disponível em: <http://www.chmtl. indiana.edu/tfm/18th/ALELIB_TEXT.html>. Acesso em: 26 mar. 2013.

Fragment sur la musique en général et sur la notre en particulier (1752). In: Oeuvres et correspondances inédites de d'Alembert publiées avec introduction, notes et appendice par Monsieur Charles Henry. Paris: Perrin, 1887. Disponível em: <http://www.chmtl.indiana.edu/ tfm/18th/ALEFRAM_TEXT.html>. Acesso em: 26 mar. 2013.

Fragment sur l'opéra (1752). In: Oeuvres et correspondances inédites de d'Alembert, publiées avec introduction, notes et appendice par Monsieur Charles Henry. Paris: Perrin, 1887. Disponível em: <http://www.chmtl.indiana.edu/tfm/18th/ALEFRA_TEXT. html>. Acesso em: 23 mar. 2013.

; DIDEROT, D. Encyclopédie, ou dictionnaire raisonné des sciences, des arts et des métiers. §15, 1734. Disponível em: <http://commons.wikimedia.org/wiki/Encyclop\%C3\%A9die,_ou_Dictionnaire_ raisonn\%C3\%A9_des_sciences,_des_arts_et_des_m\%C3\%A9tiers $>$. Acesso em: 25 fev. 2014.

INSTITUTO ANTÔNIO HOUAISS. Dicionário Houaiss conciso. São Paulo: Moderna, 2011.

DUBOS, A. Réflexions critiques sur la poésie et sur la peinture. Paris: École Nationale Supériure des Beaux-Arts, 1993.

FABIANO, A. La "Querelles des Bouffons" dans la vie culturelle française du XVIII e siècle. Paris: CNRS Éditions, 2005.

FUBINI, E. Estética da música. Lisboa: Edições 70, 1993.

La estética musical desde a Antigüedad hasta el siglo XX. Madri: Alianza Editorial, 2007. 1983.

. Les philosophes et la musique. Paris: Librairie Honoré Champion, 1986.

Musica e cultura nel settecento europeu. Torino: Edizioni di Torino, 
GOLDMANN, L. El hombre y lo absoluto. Barcelona: Ediciones Península, 1968.

. Le dieu caché: étude sur la vision tragique dans les Pensées de Pascal et dans le théâtre de Racine. Paris: Éditions Gallimard, 1959. Racine. Paris: L'Arche Editeur, 1970. Situation de la critique racinienne. Paris: L'Arche Editeur, 1971.

GRANDVAL, N. R. de. Essai sur le bon goust en musique. Paris: Pierre Prautl, 1732. Disponível em: <http://www.chmtl.indiana.edu/ tfm/18th/GRANESS_TEXT.html>. Acesso em: 26 mar. 2013.

JAPIASSÚ, H.; MARCONDES, D. Dicionário básico de Filosofia. Rio de Janeiro: Jorge Zahar, 2001.

KINTZLER, C. Poétique de l'opéra français, de Corneille à Rousseau. Paris: Minerve, 2006.

KRA, P. The concept of national character in $18^{\text {th }}$ century France. Cromohs 7: 1-6, 2002. Disponível em: <http://www.cromohs.unifi.it/7_2002/ kra.html>. Acesso em: 3 abr. 2013.

LA BRUYÈRE, J. de. Les caractères. Paris: Éditions Garnier Frères, 1962. . Os caracteres. Lisboa : Livraria Sá da Costa, 1941.

LANCASTER, H. C. A history of french literature in the seventeenth century, part V, recapitulation 1610-1700. Maryland: The Johns Hopkins Press, 1942.

LEBRUN, G. O conceito de paixão. In: NOVAES, A. (Org.). Os sentidos da paixão. São Paulo: Companhia das Letras, 2006.

LE BRUN, A.-L. Réponse a une epistre satyrique contre l'opéra. In: Théatre Lyrique: avec une Préface, ou l'on traite du Poëme de l'Opéra. Paris: Pierre Ribou, 1712. Disponível em: <http://www. chmtl.indiana.edu/tfm/18th/LEBREP_TEXT.html>. Acesso em: 26 mar. 2013.

LECERF DE VIÉVILLE, J. L. Comparaison de la musique italienne et de la musique françoise. Bruxelles: Foppens, 1705 (reprint Ed. Genève, Minkoff, 1972). Disponível em: <http://www.chmtl.indiana.edu/ tfm/18th/CERCOM1_TEXT.html>. Acesso em: 26 mar. 2013.

MORELLET, A. Da expressão em música e da imitação das artes. Tradução de Lia Tomás. São Paulo, 2014.

NAITO, Y. La pensée musicale de Rousseau. Tóquio: L’Université de Kansai, 2002.

NEUBAUER, J. La emancipación de la música: el alejamiento de la mímesis en la estética del siglo XVIII. Madri: Visor Dis., S.A., 1992.

PICCIOLA, L. Genres libres et contraintes des règles; modernisation et souplesse de la tragédie: la pastorale dramatique. In: BURY, E. et al. 
Littérature française du XVII e siècle. Paris: Presses Universitaires de France, 1992.

RAGUENET. Défense du parallele des Italiens et des François. Paris: 1705.

Disponível em: < http://www.chmtl.indiana.edu/tfm/18th/RAG-

DEF_TEXT.html>. Acesso em: 26 mar. 2013.

Paralele des Italiens et des François en ce regarde la musique et les

opéra. Paris: 1702. Disponível em: <http://www.chmtl.indiana.edu/ tfm/18th/RAGPAR_TEXT.html>. Acesso em: 26 mar. 2013.

REILL, P. H.; WILSON, E. J. Encyclopedia of Enlightenment. New York:

Facts on Fale, 2004.

ROSENFELD, A. Literatura e personagem. In: CANDIDO, Antonio et al. A personagem de ficção. São Paulo: Perspectiva, 1970.

ROUSSEAU, J.-J. Carta sobre a música francesa. Campinas: IFCH-Unicamp, 2005.

ROVIGHI, S. V. História da Filosofia moderna: da revolução científica a Hegel. São Paulo: Loyola, 2006.

SABATIER, F. Miroirs de la musique: la musique et ses correspondances avec la littérature et les beaux-arts, de la Renaissance aux Lumières $\mathrm{XV}^{\mathrm{e}}$-XVIII ${ }^{\mathrm{e}}$ siècles. Paris: Librairie Arthème Fayard, 1998. t.1.

SADIE, Stanley. Dicionário Grove de música, edição concisa. Rio de Janeiro: Jorge Zahar, 1994.

SAINT-MARD, R. Refléxions sur l'opéra. La Haye: Jean Neaulme, 1741. Disponível em: <http://www.chmtl.indiana.edu/tfm/18th/ REMREF_TEXT.html>. Acesso em: 26 mar. 2013.

STEVENS, J. The meanings and uses of caractère in eighteenth-century france. In: COWART, G. French musical thought, 1600-1800. Michigan: Ann Arbor, 1989.

VÁZQUEZ, A. S. Convite à estética. Rio de Janeiro: Civilização Brasileira, 1999.

WYMEERSCH, B. van. Descartes et l'évolution de l'esthétique musicale. Bélgica: Pierre Mardaga Editeur, 1999.

\section{Referências complementares}

ANCELET. Observations sur la musique, les musiciens, et les instrumens. Amsterdam, 1757. Disponível em: <http://www.chmtl.indiana.edu/ tfm/18th/ANCOBS_TEXT.html>. Acesso em: 26 mar. 2013. 
AUERBACH, E. Mímesis: a representação da realidade na literatura ocidental. São Paulo: Perspectiva, 1971.

BELAVAL, Y. L'esthétique sans paradoxe de Diderot. Paris: NRF Éditions Gallimard, 1991.

CARMO, M. S. M. do. Confissões de Fedra: composição trágica e coerção temporal. São Paulo, 2001. Dissertação (Mestrado) - Faculdade de Filosofia, Letras e Ciências Humanas, Universidade de São Paulo.

CHARTIER, R. (Org.). História da vida privada 3: da Renascença ao século das luzes. São Paulo: Companhia das Letras, 2009.

. Leituras e leitores na França do Antigo Regime. São Paulo: Editora da Unesp, 2003.

DESCARTES, R. As paixões da alma. São Paulo: Abril Cultural, 1983.

DIDIER, B. Histoire de la littérature française du XVIII e siècle. Poitiers: Éditions Nathan, 1992.

La musique des Lumières: Diderot - L'Encyclopédie - Rousseau. Paris: Presses Universitaires de France, 1985.

ELIAS, N. A sociedade de corte. Rio de Janeiro: Jorge Zahar, 2001.

EULER, L. Du veritable caractere de la musique moderne. Leipzig: Teubner, 1926. Disponível em: <http://www.chmtl.indiana.edu/ tfm/18th/EULVER_TEXT.html>. Acesso em: 26 mar. 2013.

ESPÍNDOLA, A. (Org.). Rousseau: pontos e contrapontos. São Paulo: Barcarolla/Discurso Editorial, 2012.

GAUTHIER, F. L. Traité contre les mauvaises chanson. In: Traité contre les danses et les mauvaises chansons. Paris: Froullé, 1785. Disponível em: <http://www.chmtl.indiana.edu/tfm/18th/GAUTRA4_ TEXT.html>. Acesso em: 26 mar. 2013.

GOUDAR, A. J.-J. S. Le brigandage de la musique italienne. Paris, 1777. Disponível em: <http://www.chmtl.indiana.edu/tfm/18th/GOUBRI_TEXT.html>. Acesso em: 26 mar. 2013.

HAUSER, A. História social da arte e da literatura. São Paulo: Martins Fontes, 2003.

HALLIWELL, S. The aesthetics of mimesis: ancient texts and moderns problems. Princeton: Princeton University Press, 2002.

KINTZLER, C. Jean-Philippe Rameau: splendeur et naufrage de l'esthétique du plaisir à l'âge classique. Paris: Éditions Le Sycomore, 1983.

Théâtre et opéra à l'âge classique: une familière étrangeté. Paris: Librairie Arthème Fayard, 2004.

KUNTZ, R. Fundamentos da teoria política de Rousseau. São Paulo: Barcarolla, 2012. 
MALHADAS, D. Tragédia grega. São Paulo: Ateliê Editorial, 2003. ; SARIAN, H. Teofrasto: os caracteres. São Paulo: EPU, 1978.

MASCARENHAS, P. S. A ética do desejo no teatro francês do século XVII. In: XI CONGRESSO INTERNACIONAL DA ABRALIC: Tessituras, Interações, Convergências. São Paulo: USP, 2008.

MATOS, F. O filósofo e o comediante: ensaios sobre literatura e filosofia na Ilustração. Belo Horizonte: Editora UFMG, 2001.

MÉNESTRIER, C.-F. Des representations en musique ancienne et modernes. Paris: René Guinard, 1681. Disponível em: <http://www.chmtl. indiana.edu/tfm/17th/MENREP1_TEXT.html>. Acesso em: 26 mar. 2013.

MEYER, M. Le comique e le tragique: penser le théâtre et son histoire. Paris: Presses Universitaires de France, 2003.

MONTESQUIEU. O gosto. São Paulo: Iluminuras, 2009.

PORTICH, A. A arte do ator entre os séculos XVI e XVIII: da Commedia dell'Arte ao paradoxo sobre o comediante. São Paulo: Perspectiva, 2008.

RAGUENET. La paix de l'opéra. In: La paix de l'opéra, ou parallele impartial de la musique et de la musique italienne. Amsterdã, 1753. Disponível em: <http://www.chmtl.indiana.edu/tfm/18th/RAGPAI_ TEXT.html>. Acesso em: 26 mar. 2013.

RIBEIRO, R. J. A glória. In: NOVAES, A. (Org.). Os sentidos da paixão. São Paulo: Companhia das Letras, 2006.

ROMILLY, J. A tragédia grega. Brasília: Editora da UnB, 1998.

ROUSSEAU, J.-J. Dissertation sur la musique moderne. Paris: P. Dupont, 1824. Disponível em: < http://www.chmtl.indiana.edu/tfm/18th/ ROUDIS_TEXT.html>. Acesso em: 26 mar. 2013. 2010.

TOMÁS, L. À procura da música sem sombra: Chabanon e a autonomia da música no século XVIII. São Paulo: Editora da Unesp/Cultura Acadêmica, 2011.

Ouvir o logos: música e filosofia. São Paulo: Editora da Unesp, 2002. 


\section{SOBRE O AUTOR}

Rodrigo Lopes. Graduado em Composição e Regência pelo Instituto de Artes Universidade Estadual Paulista "Júlio de Mesquita Filho". Graduando em Letras Clássicas - Grego Antigo pelo Departamento de Letras Clássicas e Vernáculas da Faculdade de Filosofia, Letras e Ciências Humanas da Universidade de São Paulo. Estudou Cravo, Baixo Contínuo e Música de Câmara na classe de Maria Eugênia Sacco no Conservatório Dramático e Musical Dr. Carlos de Campos, em Tatuí, São Paulo. Mestre em Música pelo Programa de Pós-Graduação em Música da Universidade Estadual Paulista "Júlio de Mesquita Filho" Instituto de Artes Unesp, sob orientação da professora doutora Lia Tomás, no ano de 2014, sendo bolsista Capes durante todo esse período. Desde 2015, é doutorando em Música pelo Programa de Pós-Graduação em Música da Universidade Estadual Paulista "Júlio de Mesquita Filho" - Instituto de Artes Unesp, sob orientação da professora doutora Lia Tomás, também bolsista Capes. 
SOBRE O LIVRO

Formato: $14 \times 21 \mathrm{~cm}$

Mancha: 23,7 x 42,5 paicas

Tipologia: Horley Old Style 10,5/14

EQUIPE DE REALIZAÇÃO

Coordenação Geral

Maria Luiza Favret 
CULTURA

ACADÊMICA

Editona 